TATIANA LEITE NUNES

AFINIDADES BIOLÓGICAS EXTRA-CONTINENTAIS DOS PALEOÍNDIOS TARDIOS DE LAGOA SANTA E SUAS IMPLICAÇÕES PARA A QUESTÃO DO POVOAMENTO DO NOVO MUNDO: UMA ABORDAGEM ODONTOMÉTRICA. 


\section{AFINIDADES BIOLÓGICAS EXTRA-CONTINENTAIS DOS PALEOÍNDIOS TARDIOS DE LAGOA SANTA E SUAS IMPLICAÇÕES PARA A QUESTÃO DO POVOAMENTO DO NOVO MUNDO: UMA ABORDAGEM ODONTOMÉTRICA.}

Dissertação apresentada ao Departamento de Genética e Biologia Evolutiva do Instituto de Biociências da Universidade de São Paulo, para a obtenção do título de Mestre em Ciências, na área de Genética e Biologia 


\section{Ficha Catalográfica}

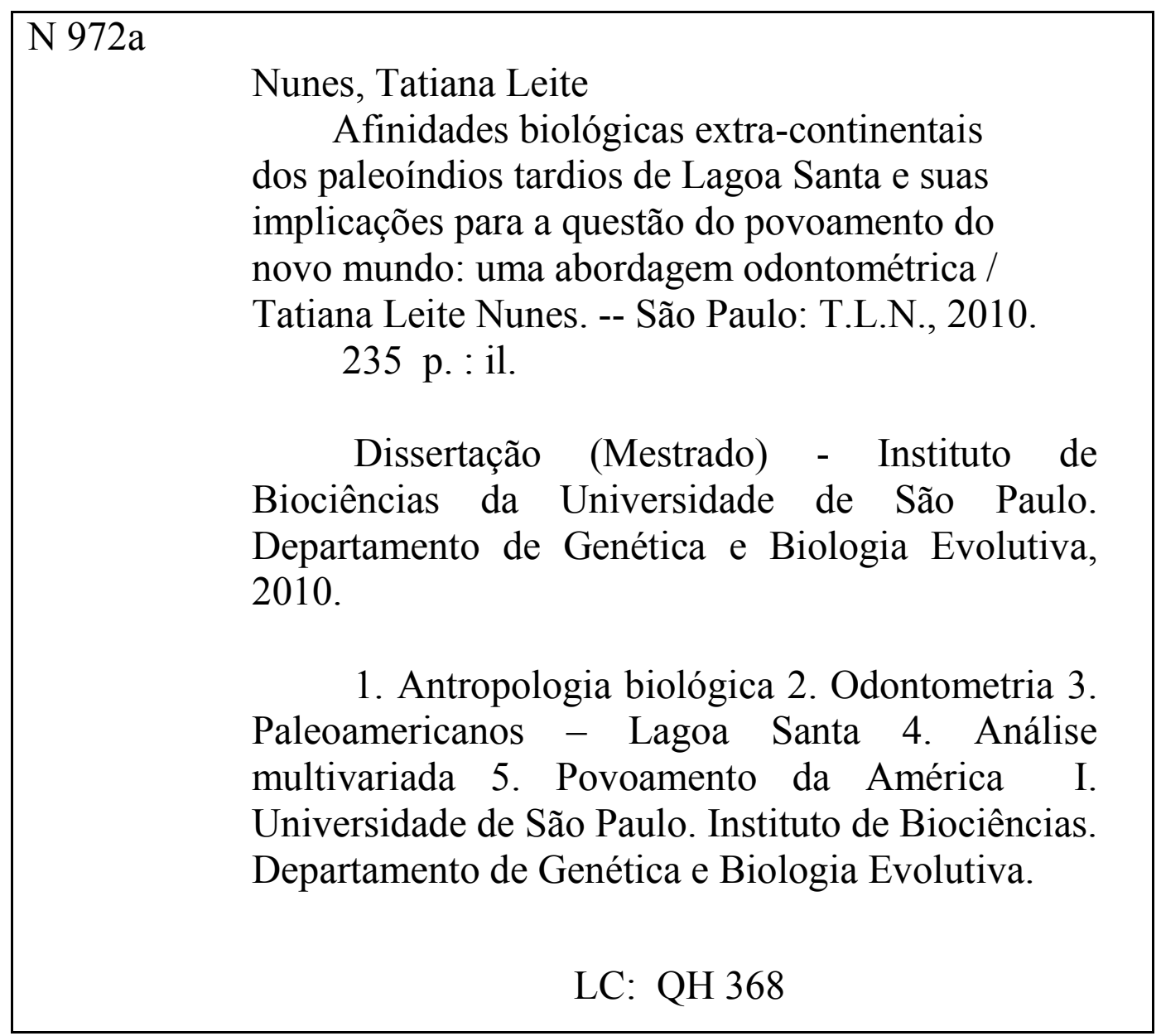

\section{Comissão Julgadora:}

Prof(a). Dr(a).

Prof(a) Dr(a).

Prof(a). Dr(a).

$\operatorname{Prof}(a) \operatorname{Dr}(a)$.

Prof. Dr. Walter Alves Neves

Orientador 
À todos que fiseram parte desta caminhada... 
"O que não me mata, fortalece-me" Nietzsche

"Nada na Biolgia faz sentido exceto à luz da Evolução" Dobzhansky 


\section{Agradecimentos}

À Universidade de São Paulo, ao Departamento de Genética e Biologia Evolutiva e ao Laboratório de Estudos Evolutivos Humanos (LEEH) por suas infra-estruturas, aprendizado e oportunidades no rico meio acadêmico uspiano.

À FAPESP pelos financiamentos concedidos tanto a mim quanto ao meu projeto de mestrado, e ao Projeto Temático "Origens e Microevolução do Homem na América: uma Abordagem Paleoantroplógica" do qual faço parte e foi indispensável à minha pesquisa.

Ao Prof. Dr. Walter Alves Neves pela oportunidade de desenvolver meu mestrado sob sua orintação, pelo aprendizado, pela infra-estrutura, pela paciência, pelos conselhos, pela amizade e por mais muitas outras coisas durante esta caminhada!

Ao Dr. Renato Kipnis por ter sido a pessoa responsável pela minha entrada no LEEH, pelo incentido e apoio mesmo quando não estava presente. Ao Prof. Dr. Rui Murrieta pela convivência, aprendizado, pelas risadas e pelos muitos conselhos. Ao Prof. Dr. Astolfo Araújo pelos ensimamentos e atividade de campo.

Aos colegas de laboratório, Alberto Barone, Alex Hubbe, André Strauss, Cassiana Purcino, Celina Nakamura, Diane Cossermelli, Elver Mayer, Helbert Medeiros, Francisco Pugliese, Letícia Gordo, Maissa Barri, Márcia Lika, Michele Tizuka, Marcos Bissaro, Mark Hubbe, Max Hernani, Murilo Pagnotta, Paulo Haddad, Pedro Damin, Pedro Totóra, Rafael Santos, Rodrigo Elias, que foram muito mais que colegas de trabalho e que os levarei comigo com muito carinho 
sempre! Especialmente ao André Strauss que esteve presente e ativamente participativo em todos os momentos do meu projeto, nas consultas aos museus, nos artigos, nas disciplinas, na monitoria, nas discussões teóricas e práticas, nas análises estatísticas, nos cafés, nas conversas, nos desabafos, nas cervejas e por aí vai; e também especialmente ao Alex Hubbe, ao Rodrigo Elias e ao Elver Mayer pela amizade, conselhos e companheirismo! Valeu time!

Aos meus queridos amigos, Amanda Gamero, Bianca Zorzi, Cinthia Caetano, Cristiane Ribeiro, Carolina Corneta, Fernada Armani, Fernanda Pestelli, Filipe Augusto, Fábio Petroni, Isabel Veloso, Ivonete Santos, João Ricardo Santos, Laura Alencar, Leonardo Cosentino, Leopoldo Prado, Mariana Pestelli, Marília Gaiarsa, Mônica Montiel, Renata Cassano, Renata de Felipe, Ricardo Perez, Ricardo Appezzato, Victor Salviati, e muitos outros, que de formas diferentes e incríveis me ajudaram, motivaram e incentivaram incondicionalmente, mesmo sem entender muitas vezes do que tudo isso se tratava!

Ao Lázaro Sanches que com sua presença fez tudo ficar mais fácil, prazeiroso e extremamente inspirador com a mais suprema simplicidade e carinho. Sua presença na fase final me deu forças e serenidade para não esmorecer nos últimos momentos e completar meus objetivos primos com elegância e dignidade.

À minha família, Renata, Jayme e Cesar, que foram e são fundamentais na minha vida de todas as formas possíveis e imagináveis!!! Aos meus tios e tias, avós, primos e primas, incentivadores eternos e maravilhosos!

Muito Obrigada por existerem e fazerem parte da minha vida! Amo todos vcs! 


\section{ÍNDICE GERAL}

1. Resumo

pg. 1

2. Introdução

pg. 3

3. Objetivos

pg. 7

4. Breve Contextualização sobre a Origem dos

Primeiros Americanos

pg. 8

4.1. Os Estudos Genéticos

pg. 11

4.2. Os achados Arqueológicos

pg. 32

4.3. Antropologia Biológica

pg. 51

4.3.1. A craniologia dos primeiros americanos

pg. 51

4.3.2. Os Estudos Odontológicos

pg. 60

4.3.2.1. A odontologia dos primeiros americanos

pg. 60

4.3.2.2. A base genético-evolutiva dos dentes humanos

pg. 73

5. Material e Métodos

pg. 80

5.1. Materiais

pg. 80

5.2. Métodos Odontométricos

pg. 84

5.2.1. O banco de dados odontométricos de Hanihara

pg. 84

5.2.2. A população de Lagoa Santa

pg. 95

5.2.3. Amostra do Museu de Anatomia Humana

Professor Alfonso Bovero

pg. 100 
5.3. Métodos Quantitativos

pg. 102

5.3.1. Análises univariadas

pg. 102

5.3.1.2. Erro Intraobservador

pg. 103

5.3.1.3. Erro Interobservador

pg. 104

5.3.1.4. Teste de Dimorfisomo Sexual

pg. 104

5.3.2. Análise Exploratória Multivariada

pg. 106

5.3.2.1. Análise de Componentes Principais

pg. 106

5.3.2.2. Substituição de valores ausentes

pg. 108

5.3.2.3. Análise de Cluster

pg. 109

5.3.2.4. Análise de Distâncias Biológicas

pg. 111

5.3.2.5. Análise de Escalonamento Multidimensional

pg. 112

6. Resultados

pg. 114

6.1. Análises Univariadas

pg. 114

6.1.1. Teste de erro intra-observador

pg. 114

6.1.2. Análise do Dimorfismo sexual

pg. 116

6.2. Análises Multivariadas

pg. 118

7. Discussão e Conclusões

pg. 186

8. Referências Bibliográficas

pg. 198 


\section{LISTA DE FIGURAS}

Figura 1 - Representação gráfica da suposta rota pelo Corredor Livre de Gelo utilizado pelos primeiros americanos por volta de 11.500A.P.. Extraído de Dixon, 2001

pg. 43

Figura 2 - Representação esquemática de como poderia ter ocorrido o povoamento das Américas ao longo das zonas ambientais por volta de 13.000A.P. proposta por Dixon (2001). Extraído de Dixon (2001)

pg. 47

Figura 3 - Representação gráfica da suposta rota costeira utilizada pelos primeiros americanos sugerida por Dixon. Extraída de Dixon (2001)

pg. 48

Figura 4 - Representação esquemática do "Modelo dos Dois Componentes Bioloógicos Principais". A notação kyr corresponde a milhares de anos antes do presente (A.P.) não calibrados

pg. 56

Figura 5 - Povoamento da América de acordo com Brace et al. (2001), de onde a figura foi extraída

pg. 58

Figura 6 - Gráfico de dispersão ao longo dos três primeiros componentes principais, extraído de Irish \& Guatelli-Steinberg (2003), com a seta vermelha destacando a população africana subsaariana; círculo verde destacando os mongolóides; círculo rosa as populações da Oceania; círculo azul as européias; e retângulo preto os australopitecineos robustos e gráceis utilizados como grupos externos

pg. 64

Figura 7 - Mapa mundial apresentando o degradê de variabilidade intra-populacional extraído de Hanihara (2008). Setas em vermelho indicam o sentido do gradiente proposto pelo autor

pg. 64

Figura 8 - Representação gráfica do componente tamanho (destacado em rosa) e forma (destacado em verde) extraída de Hanihara (1977)

pg. 66

Figura 9 - Dendrogramas extraídos de Powell (1993). A) Árvore produzida pelo agrupamento de UPGMA baseada nos dados de MMD para 28 traços morfológicos; B) Árvore produzida sob a distância de Wagner do 28 traços morfodentários usando a optimização de Fitch-Margoliash; e C) Árvore produzida pelo consenso da Máxima Parcimônia utilizando 12 segmentos codificadores sinapomorficos de traços morfodentários. Em destaque (ćŕrculos) a posição dos 
Figura 10 - Afinidades Biológicas entre as populações mundiais com base em Análise de Componentes Principais (dados corrigidos por C-Score), extraído de Hanihara \& Ishida (2005). Destaque para os círculos inseridos na figura: roxo para o Continente Americano, vermelho para a África Sub-saariana, verde para o Leste e o Norte asiáticos, e azul para Europa

pg. 72

Figura 11 - Medidas dentárias 1A- diâmetros mesiodistal e bucolingual em incisivos; 1Bdiâmetros mesio-distal e buco-lingual em molares

pg. 81

Figura 12 - Exemplo esquemático das medidas tomadas em uma arcada e orientações anatômicas utilizadas como referência

pg. 82

Figura 13 - Limite de desgaste tolerado para a tomada das medidas. A: limite para dentes incisivos e caninos e B: limite para dentes pré-molares e molares

pg. 84

Figura 14 - Exemplar analisado proveniente do Sítio Lapa do Santo, Sepultamento XXII, depositado no Laboratório de Estudos Evolutivos Humanos - USP (A: crânio e mandíbula, ambos em vista frontal; $B$ : destaque para a face bucal dos dentes maxilares do lado esquerdo; e C: destaque para a mandíbula, vista lateral direita)

pg. 97

Figura 15 - Exemplar analisado proveniente do Sítio Lapa Vermelha IV popularmente conhecido como Luzia depositado na coleção do Museu Nacional - UFRJ (A: crânio, vista frontal; B: crânio, vista lateral direita; $\mathrm{C}$ : destaque para os dentes maxilares, vista oclusal; $\mathrm{D}$ : destaque para a mandíbula lado direito e lado esquerdo, vista oclusal)

pg. 98

Figura 16 - Exemplar analisado proveniente do Sítio Lapa Mortuária de Confins, popularmente conhecido como Homem de Confins, depositado na coleção Harold Walter do Museu de História Natural - UFMG (A: crânio, vista lateral esquerda; B: destaque para os dentes maxilares, vista oclusal; e C: destaque para a mandíbula, vista oclusal)

pg. 98

Figura 17 - Exemplar analisado proveniente do sítio Santana do Riacho, Sepultamento Va, depositado na coleção Santana do Riacho do Museu de História Natural da - UFMG (A: crânio, vista lateral esquerda; B: destaque para os dentes maxilares, vista frontal; e C: destaque para a mandíbula, vista lateral direita)

Figura 18 - Exemplar analisado proveniente da Gruta do Sumidouro depositado na coleção do Museu de História Natural de Copenhaguem (A: face, vista frontal e mandíbula, vista oclusal; B: 
destaque para os dentes maxilares, vista oclusal e C: destaque para a mandíbula, vista lateral direita)

pg. 99

Figura 19 - Indivíduo do sexo masculino em vista lateral esquerda e frontal

pg. 101

Figura 20 - Indivíduo do sexo feminino em vista lateral esquerda e frontal

pg. 102

Figura 21 - Diagramação esquemáticas da sucessão de análises estatísticas que foram realizadas neste trabalho

pg. 113

Figura 22 - Screeplot representando o decaimento das porcentagens de variância explicada por cada componente principal. Parcela masculina, tamanho e forma (73 populações, 32 variáveis)

pg. 120

Figura 23 - Projeção das variáveis no morfo-espaço definido pelos dois primeiros Componentes Principais. Parcela masculina, tamanho e forma (73 populações, 32 variáveis)

pg. 122

Figura 24 - Morfo-espaço formado pelos $1^{\circ}$ e $2^{\circ}$ componentes principais. Parcela masculina, tamanho e forma (73 populações, 32 variáveis)

pg. 124

Figura 25 - Escalonamento Multidimensional produzido sobre a matriz de Distâncias de Mahalanobis (agrupamento por populações locais). Parcela masculina, somente tamanho e forma)

pg. 129

Figura 26 - Dendrograma produzido pelo critério de ligação pela média não-ponderada sobre a matriz de Distâncias de Mahalanobis (populações agrupadas por grandes regiões geográficas). Parcela masculina, tamanho e forma

pg. 132

Figura 27 - Dendrograma produzido pelo critério de ligação de Ward sobre matriz de Distâncias de Mahalanobis (com as populações agrupadas por grandes regiões geográficas). Parcela masculina, tamanho e forma

pg. 133

Figura 28 - Gráfico tridimensional produzido por Escalonamento Multidimensional sobre a matriz de Distâncias de Mahalanobis (com as populações agrupadas por grandes regiões geográficas). Parcela masculina, tamanho e forma)

pg. 133

Figura 29 - Screeplot representando o decaimento das porcentagens de variância explicada por cada Componente Principal. Parcela masculina, somente forma (73 populações, 32 variáveis)

pg. 135 
Figura 30 - Projeção das variáveis no morfo-espaço definido pelos dois primeiros Componentes Principais. Parcela masculina, somente forma (73 populações, 32 variáveis)

pg. 138

Figura 31 - Morfo-espaço formado pelos $1^{\circ}$ e $2^{\circ}$ componentes principais. Parcela masculina, somente forma (73 populações, 32 variáveis)

pg. 139

Figura 32 - Dendrograma produzido pelo critério de ligação pela média não-ponderada a partir dos cinco primeiros componentes principais (Distâncias Euclidianas). Parcela masculina, somente forma

pg. 141

Figura 33 - Dendrograma produzido pelo critério de Ward a partir dos cinco primeiros componentes principais (Distâncias Euclidinas). Parcela masculina, somente forma

pg. 143

Figura 34 - Dendrograma produzido pelo critério de ligação pela Média não-ponderada sobre a matriz de Distâncias de Mahalanobis (agrupamento por populações locais). Parcela masculina, somente forma

pg. 147

Figura 35 - Dendrograma produzido pelo critério de Ward sobre a matriz de Distâncias de Mahalanobis (agrupamento por populações locais). Parcela masculina, somente forma

pg. 149

Figura 36 - Escalonamento mutlidimensional produzido sobre a matriz de Distâncias de Mahalanobis (agrupamento por populações locais). Parcela masculina, somente forma

pg. 150

Figura 37 - Dendrograma produzido pelo critério de ligação pela Média não-ponderada sobre a matriz de Distâncias de Mahalanobis (com as populações agrupadas por grandes grupos). Parcela masculina, somente forma

pg. 153

Figura 38 - Dendrograma produzido pelo critério de ligação de Ward sobre a matriz de Distâncias de Mahalanobis (com as populações agrupadas por grandes grupos). Parcela masculina, somente forma

pg. 153

Figura 39 - Gráfico tridimensional produzido pela Análise de Escalonamento Multidimensional sobre a matriz de Distâncias de Mahalanobis (com as populações agrupadas por grandes regiões geográficas). Parcela masculina, somente forma)

pg. 154 
Figura 40 - Screeplot representando o decaimento das porcentagens de variância explicadas por cada componente principal. Parcela Feminina, tamanho e forma (43 populações, 32 variáveis)

pg. 156

Figura 41 - Projeção das variáveis no morfo-espaço definido pelos dois primeiros Componentes Principais. Parcela feminina, tamanho e forma (43 populações, 32 variáveis)

pg. 159

Figura 42 - Morfo-espaço formado pelos $1^{\circ}$ e $2^{\circ}$ componentes principais. Parcela Feminina, tamanho e forma (43 populações, 32 variáveis)

pg. 160

Figura 43 - Dendrograma produzido pelo critério de ligação por média não-ponderada a partir dois três primeiros componentes principais (Distâncias Euclidianas). Parcela feminina, tamanho e forma

pg. 163

Figura 44 - Dendrograma produzido pelo critério de Ward a partir dois três primeiros componentes principais (Distâncias Euclidianas). Parcela feminina, tamanho e forma pg. 164

Figura 45 - Escalonamento Multidimensional produzido sobre a matriz de Distâncias de Mahalanobis (agrupamento por populações locais). Parcela feminina, tamanho e forma (43 populações, 32 variáveis)

pg. 167

Figura 46 - Escalonamento Multidimensional produzido sobre a matriz de Distâncias de Mahalanobis (agrupamento por grandes regiões geográficas). Parcela feminina, tamanho e forma (43 populações, 32 variáveis)

pg. 170

Figura 47 - Screeplot representando o decaimento das porcentagens de variância total explicadas por cada Componente Principal. Parcela Feminina, somente forma (43 populações, 32 variáveis)

pg. 171

Figura 48 - Projeção das variáveis no morfo-espaço definido pelos dois primeiros Componentes Principais. Parcela feminina, somente forma (43 populações, 32 variáveis)

pg. 174

Figura 49 - Morfo-espaço formado pelos $1^{\circ}$ e $2^{\circ}$ componentes principais. Parcela feminina, somente forma (43 populações, 32 variáveis)

pg. 175

Figura 50 - Dendrograma produzido pelo critério de ligação por média não-ponderada a partir dos cinco primeiros componentes principais (Distâncias Euclidianas). Parcela feminina, somente forma 
Figura 51 - Dendrograma produzido pelo critério de Ward a partir dos cinco primeiros componentes principais (Distancias Euclidianas). Parcela feminina, somente forma

pg. 178

Figura 52 - Escalonamento Multidimensional produzido sobre a matriz de Distâncias de Mahalanobis (populações agrupadas por grandes regiões geográficas). Parcela feminina, somente forma (43 populações, 32 variáveis)

pg. 183

Figura 53 - Escalonamento Multidimensional produzido sobre a matriz de Distâncias de Mahalanobis (agrupamento por populações locais). Parcela feminina, somente forma (43 populações, 32 variáveis)

pg. 184 


\section{LISTA DE TABELAS}

Tabela 1 - Variáveis odontométricas utilizadas neste estudo, baseadas em Morreess et al., 1957

pg. 82

Tabela 2 - Distribuição das populações masculinas e femininas utilizadas neste trabalho segundo divisão sugerida por Hanihara \& Ishida (2005)*

pg. 85

Tabela 3 - Exemplo de arquivo sem formatação recebido do Dr. Haniraha

pg. 92

Tabela 4 - Arquivo informativo sobre o Banco de Dados Hanihara

pg. 93

Tabela 5 - Formatação final de uma única população do banco de dados Hanihara, a título de exemplo

pg. 94

Tabela 6 - Identificação dos crânios constituintes da amostra esqueletal paleoíndia de Lagoa Santa

pg. 95

Tabela 7 - Descrição da amostra coletada no Museu de Anatomia Humana - USP

pg. 101

Tabela 8 - Símbolos utilizados nos gráficos de Componentes Principais e de Escalonamento Multidimensional pg. 114

Tabela 9 - Resultados dos testes-t pareados e das correlações de Pearson

pg. 115

Tabela 10 - Resultado das ANOVAs para os testes de dimorfismo sexual

pg. 116

Tabela 11 - Autovalores e percentuais de variância explicada pelos primeiros oito componentes principais. Parcela masculina, tamanho e forma (73 populações, 32 variáveis)

pg. 119

Tabela 12 - Correlação entre as variáveis originais e os componentes principais extraídos. Parcela masculina, tamanho e forma (73 populações, 32 variáveis)

pg. 121

Tabela 13 - Índices Cofenéticos para os diferentes critérios de "clustering" a partir de Distâncias Euclidianas. Parcela masculina, tamanho e forma (73 populações, 32 variáveis)

pg. 125

Tabela 14 - Matriz de Distâncias de Mahalanobis (agrupamento realizado por populações locais). Parcela masculina, somente forma

pg. 126

Tabela 15 - Matriz de Distâncias de Mahalanobis (populações agrupadas por grandes regiões geográficas). Parcela 
Tabela 16 - Índices Cofenéticos para os diferentes critérios de "clustering" a partir de Distâncias de Mahalanobis. Parcela masculina, tamanho e forma (73 populações, 32 variáveis)

Tabela 17 - Autovalores e percentuais de variância explicada pelos primeiros dezessete componentes principais. Parcela masculina, somente forma (73 populações, 32 variáveis)

Tabela 18 - Correlação entre as variáveis originais e os componentes principais extraídos. Parcela masculina, somente forma (73 populações, 32 variáveis)

pg. 136

Tabela 19 - Índices Cofenéticos para os diferentes critérios de "clustering" a partir de Distâncias Euclidianas. Parcela masculina, somente forma (73 populações, 32 variáveis)

pg. 140

Tabela 20 - Índices Cofenéticos para os diferentes critérios de "clustering" a partir de Distâncias de Mahalanobis. Parcela masculina, somente forma (73 populações, 32 variáveis)

Tabela 21 - Matriz de Distâncias de Mahalanobis (agrupamento realizado por populações locais). Parcela masculina, somente forma

pg. 145

Tabela 22 - Matriz de Distâncias de Mahalanobis (populações agrupadas por grandes regiões geográficas). Parcela masculina, somente forma (73 populações, 32 variáveis)

pg. 152

Tabela 23 - Autovalores e percentagens de variância explicada pelos primeiros onze componentes principais. Parcela feminina, tamanho e forma (43 populações, 32 variáveis)

pg. 155

Tabela 24 - Correlação entre as variáveis originais e os componentes principais extraídos. Parcela feminina, tamanho e forma (43 populações, 32 variáveis)

pg. 157

Tabela 25 - Índices Cofenéticos para os diferentes critérios de "clustering" a partir de Distâncias Euclidianas. Parcela feminina, tamanho e forma (43 populações, 32 variáveis)

pg. 162

Tabela 26 - Índices Cofenéticos para os diferentes critérios de "clustering" a partir de Distâncias de Mahalanobis. Parcela feminina, tamanho e forma (43 populações, 32 variávies)

pg. 164

Tabela 27 - Matriz de Distancias de Mahalanobis (agrupamento realizado por populações locais). Parcela feminina, tamanho e forma (43 populações, 32 variáveis)

pg. 165

Tabela 28- Matriz de Distancias de Mahalanobis (populações agrupadas por grandes regiões geográficas). Parcela 
Tabela 29 - Autovalores e percentagens de variância explicada pelos primeiros dezesseis Componentes Principais. Parcela feminina, somente forma (43 populações, 32 variáveis)

pg. 170

Tabela 30 - Correlação entre as variáveis originais e os componentes principais extraídos. Parcela feminina, somente forma (43 populações, 32 variáveis)

pg. 172

Tabela 31 - Índices Cofenéticos para os diferentes critérios de "clustering" a partir de Distâncias Euclidianas. Parcela feminina, somente forma (43 populações, 32 variáveis)

pg. 176

Tabela 32 - Índices Cofenéticos para os diferentes critérios de "clustering" a partir de Distâncias de Mahalanobis. Parcela femina, somente forma (43 populações, 32 variáveis)

pg. 178

Tabela 33 - Matriz de Distâncias de Mahalanobis (agrupamento realizado por populações locais). Parcela feminina, somente forma (43 populações, 32 vairáveis)

pg. 179

Tabela 34 - Matriz de Distâncias de Mahalanobis (populações agrupadas por grandes regiões geográficas). Parcela feminina, somente forma (43 populações, 32 variáveis)

pg. 182 


\section{$\underline{1 . \text { Resumo }}$}

Atualmente, quatro principais modelos discutem o Povoamento da América. O mais antigo defende a entrada de três levas migratórias (Greenberg et al., 1986), outro modelo, duas (Neves et al., 1989), o modelo genético, apenas uma (Bonatto \& Salzano, 1997) e, recentemente, Gonzalez-José et al. (2008) apresentaram um modelo de fluxo continuo. O presente trabalho investigou as afinidades biológicas de uma população paleoíndia brasileira, a de Lagoa Santa, com antiguidade estimada entre 11.500-7.500 A.P., comparandoa a outras populações mundiais (Banco de Dados Hanihara). A investigação baseou-se em análise odontométrica (diâmetros dentários mesiodistais e bucolinguais). Os dentes apresentam alta herdabilidade, morfogênese estável, grande representatividade arqueológica e são pouco influenciados por fatores ambientais imediatos. As afinidades biológicas dos paleoíndios de Lagoa Santa foram exploradas por Análise Multivariada, com a aplicação de Análise de Componentes Principais e Matrizes de Dissimilaridade (Euclidianas e Mahalanobis), estas últimas visualizadas por Análises de Cluster e de Escalonamento Multidimensional. Diferentes sets de análises foram realizados, para ambos os sexos considerando-se "tamanho e forma" e "somente forma". Os resultados apresentados demonstram uma forte tendência de diferenciação da população de Lagoa Santa em relação às populações nativas americanas tardias e atuais, associando-se mais fortemente com Polinésios e Sudeste Asiáticos. Estes resultados questionam a homogeneidade dos nativos americanos e apóiam fortemente o modelo dos Dois Componentes Biológicos Principais (Neves et al., 1989). 


\section{$\underline{\text { Abstract }}$}

Nowadays, four principal models discuss the settlement of the Americas. The oldest one defends three waves into the continent (Greenberg et al, 1986), other model, two (Neves et al., 1989), the gentic one, only one (Bonatto \& Salzano, 1997), and recently, Gonzalez et al. (2008) presented a continuous flow model. The present study investigated the biological affinities of a Paleoindian Brazilian population, Lagoa Santa, with estimated antiquity between 11500-7500AP, comparing them to others word populations (Hanihara Data Bank). The investigation was based on odontometry data (mesiodistal and bucolingual diameters). Teeth have high heritability, stable morphogenesis, high archaeological presence, and are little influenced by immediate environmental factors. The biological affinities of Lagoa Santa Paleoindians were explored by Multivariate Analyses, with the application of Principal Components Analysis and Matrix Dissimilarities (Euclidian and Mahalanobis), the later visualized by Cluster Analysis and Multidimensional Scaling. Different sets of analysis were carried out for both sexes considering "size and shape" and "shape alone". The results point to a strong tendency of differentiation of the Lagoa Santa population in relation to other Native Americans, and a strong association with Southeast Asians and Polynesians. The results strongly support the Two Main Biological Components Model (Neves et al., 1989). 


\section{Introdução}

A existência de populações nativas na "descoberta" da América com a chegada dos espanhóis no século XV causou interesse na comunidade científica desde então. Recentemente, com o surgimento de modelos mais complexos para explicar a chegada do homem à América, tal tema ocupa uma posição de destaque nos debates arqueológicos e bioantropológicos mundiais. Esses modelos buscaram de forma interdisciplinar beber em diferentes fontes do conhecimento, principalmente na genética, na arqueologia, na bioantropologia e na linguística.

O estudo da genética dos nativos americanos pode ser resumido, de maneira superficial em duas grandes fases. Em um primeiro momento, os geneticistas utilizaram os produtos gênicos, proteínas e derivados, para os estudos de afinidades biológicas extra-continentais (Matson et al., 1967; Kirk, 1979; Williams et al., 1985). Já em uma segunda fase, o seqüenciamento do DNA tornou-se possível, alterando assim o foco específico das pesquisas, analisando agora diretamente o código genético dos nativos americanos (e.g. Szathmary, 1993; Cann, 1994; Gibbons, 1993, 1996; Bonatto \& Salzano, 1997a e b; Zegura et al., 2004).

De forma abrangente os estudos de Genética Molecular (e.g. Schurr et al., 1990; Pena et al., 1995; Bonatto \& Salzano, 1997a e b; Zegura et al., 2004) chegaram a resultados semelhantes aos das pesquisas que utilizaram os marcadores protéicos (Matson, et al., 1967; Kirk, 1979; Williams et al., 1985; Cavalli-Sforza et al., 1988). Admitia-se até recentemente, que todas as 
populações nativas do continente americano, ou pelo menos aquelas hoje ainda representadas, são oriundas de uma única região geográfica do leste asiático (Sibéria), com uma temporalidade que varia entre 13.000-58.000 A.P. (CavalliSforza et al., 1994; Bonatto \& Salzano, 1997; Bianchi et al., 1998; Zegura et al., 2004).

No campo da Arqueologia, tradicionalmente se aceita a idade máxima de 11.050 A.P. para a presença do homem no continente americano, referente aos mais antigos vestígios da cultura Clovis (Walters \& Stafford Jr, 2007). Esta cronologia corrobora o "Modelo das Três Migrações" (Turner II, 1983; Greenberg et al., 1986; Turner II, 2002) para explicar o processo de ocupação pré-histórica da América. O modelo defende que a América foi ocupada recentemente por populações de morfologia mongolóide/sinodonte oriundas do nordeste asiático, em três levas migratórias independentes.

Pesquisas arqueológicas mais recentes realizadas no hemisfério norte questionam o modelo "Clovis-frist" (Adovasio et al., 1998; Goodyear, 1999; McAvoy et al., 2000; Collins, 2002; Lovgren, 2003; Bradley \& Stanford, 2004; Walters \& Stafford Jr., 2007). Na América do Sul, vários arqueólogos também vêm reunindo evidências para contestar o modelo "Clovis-first" (Neves et al., 1999a, b, c, d, e; Prous, 1992, 1997, 2006; Guidon \& Delibrias, 1996; Dillehay, 1997, 1999, 2008; Meltzer et al., 1997; Fagan, 1999; Roosevelt et al. 2002; Miotti \& Salemme, 2003).

Análises de dados craniométricos visando caracterizar a variabilidade morfológica craniana dos primeiros habitantes da América têm tido posição central nos debates mais acirrados a respeito das origens do homem no 
continente na última década. Alguns desses trabalhos mostraram que, diferentemente do proposto pelo "Modelo das Três Migrações", a morfologia craniana dos primeiros americanos não pode ser associada à variação mongolóide (Neves \& Pucciarelli, 1989, 1990, 1991; Powell \& Steele, 1992; Steele \& Powell, 1992, 1993; Jantz \& Owsley, 2001, 2005; Owsley \& Jantz, 2005; Hubbe et al., 2007). Neves et al. (1999) propuseram um modelo alternativo para explicar a variabilidade encontrada, o "Modelo dos Dois Componentes Biológicos Principais", sugerindo a entrada de duas populações biologicamente diferentes no continente americano, uma que se associa morfologicamente às populações australo-melanésicas e africanas e outra que se associa às populações do nordeste asiático.

Além das relações observáveis através das afinidades morfocranianas, o estudo da morfologia dentária tem contribuído para as discussões sobre as origens dos primeiros americanos. A variação odontométrica também tem sido utilizada para a investigação da evolução hominínea de maneira mais ampla e da diversidade local e regional dos grupos humanos recentes (Brace, 1980; Scott \& Lockwood, 2004; Bermudez de Castro et al., 2004).

Turner II (1981, 1983 e 1985) antes mesmo de propor o "Modelo das Três Migrações" já afirmava que, sem exceções, os índios americanos possuem dentes morfologicamente mais parecidos com os dos asiáticos, sugerindo a ocorrência de uma reduzida evolução na América nos últimos 11.000 anos. Powell (1993) se propôs a revisar as análises realizadas por Turner II (1985, 1992) e por Greenberg et al. (1986) e identificou problemas nas suposições teóricas de suas análises estatísticas. De acordo com Powell (1993) os 
paleoíndios realmente agrupam-se com as populações do Novo Mundo, porém mantém alguma distância delas, sugerindo sua antiguidade e uma posição única em relação às demais populações americanas, em todas as análises realizadas.

$\mathrm{O}$ presente trabalho baseou-se numa abordagem complementar às análises craniométricas realizadas por Neves e colaboradores nos últimos 20 anos, lançando mãos de caracteres odontométricos. A morfologia dentária distingue-se dos demais marcadores morfológicos por ter alta herdabilidade, excelente preservação arqueológica comparativamente à outras partes do esqueleto e por poder ser analisada tanto em indivíduos adultos quanto jovens - contanto que tenham dentição permanente - (Hanihara \& Ishida, 2005; Stojanowski et al., 2007). Desta forma, uma análise das afinidades biológicas através da morfologia dentária comparada dos Paleoíndios da Região Arqueológica de Lagoa Santa com diferentes séries mundiais possibilitou uma avaliação independente das afinidades biológicas do grupo, em nível extracontinental. 


\section{Objetivos}

O presente trabalho propõe-se a investigar as afinidades biológicas dos remanescentes esqueletais de Lagoa Santa comparando-os com outras séries esqueletais de diversas regiões do mundo através da comparação estatística multivariada de dados odontométricos. O objetivo é averiguar, de forma independente, as relações biológicas cranianas primeiramente observadas por Neves \& Pucciarelli (1989), que sugerem que a ocupação do Novo Mundo se deu a partir da chegada de dois componentes biológicos distintos. Se o modelo estiver correto, espera-se que seja observada uma estreita relação biológica entre a população de Lagoa Santa e as populações australo-melanésicas e africanas recentes e sub-atuais em detrimento às asiáticas e americanas atuais. 


\section{Breve Contextualização sobre a Origem dos Primeiros}

\section{Americanos}

O interesse a respeito dos povos nativos americanos data da chegada dos primeiros colonizadores europeus à América no século XV com a expedição de Cristóvão Colombo em 1492 às Bahamas. A descoberta de um Novo Mundo e de novos povos deu início, naquele momento, a um fascínio pelo desconhecido por parte dos europeus, gerando uma série de teorias e debates sobre a origem e a antiguidade dessas populações (Fagan, 1987; Munford, 1999).

De forma bem abrangente, até o século XVII a maior parte das suposições geradas não possuíam embasamento teórico e científico e baseavam-se nas escrituras bíblicas do Velho Testamento. Alguns poucos escritos deste período trataram de forma menos especulativa as questões centrais sobre os nativos americanos, porém de forma muito enviesada e sentimental, como é o exemplo de Bartolomé de Las Casas, Bernadino de Salvador e Diego de Landa (para uma revisão ver Fagan, 1987). No entanto estes ainda se apoiavam nos dogmas religiosos para suas suposições já que na época não existia nenhuma fonte histórica objetiva para alicerçar seus trabalhos.

Com um crescente interesse gerado nos círculos intelectuais europeus da Botânica, da Zoologia e da Antropologia, associado com o intenso intercâmbio dos nobres europeus com viajantes e entusiastas em relação aos indígenas americanos, a questão tomou corpo. Nomes como Thomas Jefferson, Benjamim 
Franklin e Benjamin Smith Barton, fazem parte desta tentativa de objetividade no estudo dos povos indígenas americanos. Mas, somente no século XVIII surgiram alguns trabalhos como o de José de Acosta e de John e Willian Bartam com cunho mais cético e imparcial (Fagan, 1987).

Durante a primeira metade do século XIX materialistas fundadores da Antropologia Física interessaram-se na variabilidade humana. As primeiras classificações estavam alicerçadas declaradamente na classificação sistemática das variedades humanas (ou seja, na classificação racial). Do inicio dos anos 1800 até 1950 as pesquisas focadas na variação biológicas humana lidavam principalmente com traços visíveis (em geral, coloração da pele) e dimensões corporais (antropometria).

Trabalhos como o de Somme River, sobre a idade da Terra; Louis Agassiz sobre os depósitos glaciais e Charles Abbott sobre ferramentas de pedra, começaram a debruçar-se novamente sobre a questão do homem americano, sobre sua origem, antiguidade e comportamento. No início dos anos 1900 o antropólogo físico Aleš Hrdlička vinculou-se ao Smithsonian Institution e dedicou-se aos estudos dos remanescentes ósseos dos supostos "homens glacias ou homens do gelo" americanos. Em 1907, afirmou que o homem americano teria origem na Ásia, mais precisamente na Sibéria, em tempos pósglaciais não antes de 4.000 anos A.P..

Em 1908 George McJunkin encontrou artefatos líticos na cidade de Folsom que mudariam definitivamente o quadro mais aceito até então para o povoamento da América (Kelly, 2003). Inicialmente desacreditado no meio científico, somente em 1927, com o suporte de outros pesquisadores de 
renome e dos achados desses sofisticados artefatos líticos associados a ossos de animais da mega-fauna extinta, que sua descoberta ganhou atenção. Uma avalanche de pesquisadores em 1928 visitou o sítio Folsom e se convenceram de que humanos haviam vivido no norte do continente americano em tempos glaciais. Esses primeiros povos são agora chamados de Paleoíndios e sua antiguidade estaria por volta de 10.000 A.P. ou até mesmo mais recuada (Fagan, 1987).

Em 1932, outro achado de grande importância veio de forma acachapante sedimentar a antiguidade do homem americano, o sítio Clovis. No entanto, somente após a segunda Guerra Mundial, em 1949, novas intervenções arqueológicas comprovaram a associação entre sofisticados artefatos líticos com ossos de mamutes. Os paleoíndios agora estavam representados pelos sítios Clovis e Folson, e seriam caçadores-coletores especializados em grandes animais pleistocênicos, ou "big game hunters" (como ficou conhecido em inglês). Somente em 1950 com o advento da datação por carbono-14, datas absolutas puderam ser estabelecidas. Amostras coletadas em Folson foram datadas em 10.000 A.P. e amostras Clovis em 11.500 A.P.. No entanto, pouco ainda se sabia biologicamente sobre os paleoíndios.

Tendo em vista a multidisciplinaridade necessária para entender uma história complexa como é a do povoamento da América, fica implícito que diversas áreas do conhecimento precisam ser analisadas. Dentre as centrais, como exposto brevemente acima, a antropologia e a arqueologia são o cerne do estudo da origem do homem americano. Porém, os estudos genéticos têm 
em muito contribuído para as investigações sobre os povos nativos americanos e não podem ser deixados de lado. Estas áreas têm fornecido informações de forma significativa, principalmente nas últimas décadas para o entendimento do povoamento do Novo Mundo.

\subsection{Os Estudos Genéticos}

Na década de 1950 com o surgimento dos estudos de Biologia Molecular, a genética tornou-se peça chave nos estudos bioantropológicos, e mais especificamente, nos estudos evolutivos e micrevolutivos humanos. As principais questões levantadas pelos estudos genéticos sobre o povoamento da América são o número de levas migratórias que entraram no continente, a origem dessas populações, a via de entrada, a antiguidade da(s) migração(ões) e a dinâmica populacional que respaldaria todas essas questões conjuntamente.

Nos primeiros trabalhos, Matson et al. (1967) e Kirk (1979) afirmaram que as populações do continente americano eram mais semelhantes com as populações polinésicas e sul-asiáticas. Somente com Willians et al. (1985) estudando-se imunoglobulinas, foi possível apontar para uma origem americana na região do nordeste asiático. No entanto, Francisco Salzano e diversos associados (Salzano et al., 1985; Salzano \& Callegari-Jacques, 1988 e 1991; Callegari-Jaques \& Salzano, 1989) apresentaram resultados contrários, segundo os quais não era possível afirmar, nem descartar os povos polinésicos e os asiáticos como ancestrais dos povos nativos americanos. Contudo, a maioria dos estudos com materiais protéicos tenderam a sugerir os asiáticos como a 
população que teria contribuído para a formação do patrimônio genético americano.

Com considerável melhoria técnica passou-se a ser possível acessar diretamente o DNA humano, diferentemente do acesso indireto ao material genético através dos produtos da expressão gênica, como realizado anteriormente. Essa mudança permitiu uma alteração significativa na autoridade dos estudos e dos resultados obtidos pela genética na questão da origem dos nativos americanos (para alguns exemplos ver Szathmary, 1993; Cann, 1994; Gibbons, 1996; Bonatto \& Salzano, 1997; Zegura et al., 2004; Fagundes et al., 2007, 2008). No início da década de 1990 os estudos de genética molecular começaram a convergir para a idéia de um povoamento americano de origem mongolóide asiática, em um número pequeno de ondas migratórias e com uma parada no decorrer da migração na Beríngia.

O trabalho clássico de Torroni et al. (1992) analisando DNA mitocondrial nativo americano pode identificar quatro haplogrupos $A, B, C$ e $D$ principais. Baillet et al. (1994) contestaram a classificação realizada por Torroni et al. (1992), afirmando que a variabilidade existente nos haplótipos A, C e D era demasiadamente grande para serem assim categorizados. Baillet e colaboradores (1994) sugeriram que os haplótipos fossem reclassificados como $A 1, A 2, C 1, C 2, D 1$ e $D 2$, e que um novo haplogrupo fosse inserido como fundador americano, denominado inicialmente de $\mathrm{E}$ (posteriormente renomeado haplótipo X). Novos haplótipos foram sendo sugeridos na literatura (e.g. Richards et al., 1998; Smith et al., 1999), no entanto nenhum outro haplótipo 
foi universalmente aceito na literatura especializada como constituinte principal das populações que povoaram o Novo Mundo.

O haplótipo X está presente em aproximadamente 3\% dos nativos norteamericanos e ausente no leste asiático, e por conseqüência, tem sido alvo de diversas teorias sobre seu surgimento. Suposições desde migração transAtlântica européia a mistura recente também européia têm sido propostas - já que este haplótipo é altamente freqüente em populações atuais da Europa e do Oriente Médio (Malhi \& Smith, 2002). Inicialmente, foi também sugerida uma migração originada no leste europeu rumo ao leste asiático que teria posteriormente entrado na América (entretanto não existia até o momento daquela publicação qualquer evidênica desse evento), o que consequentemente levou a assunção de que indivíduos de ancestralidade caucasiana adentraram no continente americano na pré-história (Brown et al., 1998). Reidla et al. (2003) sugeriram que as duas variedades típicas americanas do haplótipo X divergiram já na América, por volta de 12-17.000A.P. ou por volta de 2336.000A.P. dependendo do método de estimação utilizado, e não anteriormente à entrada no continente.

Somente em 2001, Derenko e colaboradores reportaram a presença do haplótipo X em populações da região do Altai no sul da Sibéria, onde os outros quatro haplótipos típicos americanos também são encontrados. Atualmente não se questiona mais que o haplótipo X esteve presente nas primeiras populações que migraram para a America, principalmente depois de diagnosticada sua presença em um espécime pré-histórico datado de aproximadamente 1.340 40 A.P. (Malhi \& Smith, 2002). Mais tarde, Achilli et al. (2008) sugeriram 
que os haplótipos principais anteriormente chamados de $A, B, C$ e $D$, (já que a nomenclatura de Baillet et al., 1994 não foi adotada) fossem agora denominados A2, B2, C1 e D1 e o quinto haplótipo, X2a (antigo X).

No que diz respeito a levas migratórias Torroni et al. (1992) sugeriram que a similaridade de seqüências nos haplótipos $A, C$ e $D$ dos ameríndios formaria a linhagem fundadora dos paleoíndios, que teriam iniciado sua irradiação entre 42.000-21.000 A.P.. O haplótipo compartilhado entre todos os Na-dene, o haplótipo A, indica que este grupo tornou-se distinto geneticamente por volta de 5.250-10.500 A.P. (condizente com as estimativas sugeridas pelo "Modelo da Três Migrações" de Greenberg et al., 1986). Starikovskaya et al. (1998), entretanto, estimaram a primeira chegada na América um pouco mais recentemente, por volta de 34-26.000A.P., seguido da chegada do haplótipo B em uma migração subseqüente por volta de 16-13.000A.P., com diferentes origens siberianas às migrações que chegaram à América.

De forma contrária, em 1993, Szathmary afirmou categoricamente que dados originados da genética não apoiam o "Modelo da Três Migrações" (Greenberg et al., 1986), já que a variância entre as populações do grupo ameríndio (intra-grupo) é maior do que a existente entre eles e as populações do circum-ártico (na-denes e esquimós) colocando sérios questionamentos à validade do modelo tradicional. De forma mais radical ainda, Horai et al. (1993), afirmaram que a variabilidade existente em cada haplótipo não seria possível de ser explicada a não ser que os haplótipos tivessem origem em migrações independentes e que permaceram isoladas por um período de tempo relativamente longo. 
Considerando as múltiplas variantes dos quarto haplótipos fundadores principais dos nativos americanos, Merriwether et al. (1995) identificaram gradientes de distribuição para os mesmos. Neste sentido, Malhi et al. (2002) julgaram que as peculiaridades encontradas nas distribuições dos haplótipos são o resultado de diferentes histórias populacionais altamente influenciadas por deriva e fluxo gênico entre os grupos. Sugerem que em um primeiro momento as populações teriam sofrido um processo de tribalização (ou seja, fortemente influenciados pelo processo de deriva) e posterior intercâmbio biosocio-cultural (ou em outras palavras, sob o impacto de fluxo gênico). Esses processos teriam influenciado mais severamente as populações com altas freqüências dos haplótipos $A, B$ e $X$ já que esses haplótipos sofreram uma maior expansão comparada com as populações com altas freqüências dos haplótipos C e D (Malhi et al., 2002).

Merriwether et al. (1995), no entanto, consideram que as diferenças existentes entre as populações Ameríndias, Na-Dene e Eskaleutas, se relacionam muito mais com a questão geográfica do que com levas migratórias, isto porque, julgaram pouco provável que todos os grupos nativos americanos possuíssem as mesmas variantes dos haplótipos sem que quaisquer outras linhagens estivessem presentes, no caso de ondas migratórias de diferentes origens. O fato das mesmas quatro linhagens haplotípicas aparecerem associadas entre os nativos americanos favorece a suposição de uma única onda migratória ou uma única população ancestral-fonte. E ainda, sugerem que tenha existido um alto grau de fluxo gênico da população parental asiática com as do Novo Mundo (Merriwether et al., 1995). Mais recentemente, diversos 
pesquisadores concordam com Merriwether et al. (1995), afirmando que toda a variação observada no continente americano pode ser acomodada em uma única leva migratória fundadora para as Américas (e.g., Bonatto \& Salzano, 1997a; Stone \& Stoneking, 1998; Malhi et al., 2002; Fagundes et al., 2008a).

O próximo passo no entendimento do povoamento do continente americano diz respeito à origem das populações migrantes e o caminho por elas realizado. Forster et al. (1996) sugeriram que o povoamento da América se deu a partir de uma única fonte populacional em uma única migração originada no nordeste da Sibéria por volta de 20.000-25.000 A.P., chegando até a porção sul do continente por volta de 13.000 A.P.. Resultados similares - uma única migração em aproximadamente 21.000A.P. - foram obtidos por Silva et al. (2002) ao analisarem sequências de mtDNA fora da região controle. Pode-se dizer, portanto, que a princípio resultados similares são obtidos independente da região analisada do DNA mitocondrial.

Bonatto \& Salzano (1997a) diagnosticaram que todos os grupos nativos americanos (Ameríndios, Na-Dene e Esquimós) são significativamente mais próximos entre si do que a qualquer grupo asiático e que, portanto, originaramse de uma única migração para a Beríngia, provavelmente a partir da Ásia Central, que ocorreu por volta de 30.000-43.000 A.P. (variando de acordo com a taxa de substituição utilizada) e para um intervalo de confiança de $95 \%$, essa estimativa seria de 22.000 a 55.000 A.P.. O fato dos Na-Dene terem uma freqüência de haplogrupo A mais baixa que os Ameríndios é explicada por Torroni et al. (1992) por uma migração separada (a frequência do haplótipo A em Na-Denes é 3,4 vezes maior do que em Ameríndios). Porém, Bonatto \& 
Salzano (1997a) argumentaram que a frequência do haplótipo A nos Na-Denes é somente 1,4 vez maior que em Ameríndios, o que seria muito baixo para justificar uma migração independente. Stone \& Stoneking (1998) analisaram material proveniente de um cemitério indígena utilizado há aproximadamente 700 anos e confirmaram um tempo de divergência por volta de 23-37.000A.P. para o haplótipo A implicando no que consequentemente, corroborou com uma única onda migratória para a entrada da América.

O'Rourke et al. (2000) deram um salto qualitativo nas suposições genéticas ao analisarem as freqüências de mtDNA de amostras de 6 populações esqueletais de idades variando entre 6.000 e 300 A.P. e de 41 populações de indígenas norte-americanas. Puderam observar que ambas as amostras exibiram o mesmo nível de variabilidade genética atual, e que apresentam-se altamente organizadas geograficamente. O'Rourke et al. (2000) acreditam que os padrões regionais de mtDNA estabeleceram-se cedo na pré-história norte americana, tendo permanecido relativamente estáveis desde então. Dito de outra forma, esses grupos foram pouco influenciados por disrupções - como declínio populacional e realocação no contato com os europeus ( $O$ 'Rourke et al., 2000).

Strarikoskaya et al. (2005) sugeriram que os ancestrais imediatos dos migrantes Siberianos/Beríngianos que deram origem às populações paleoíndias (pré-Clóvis) têm uma origem comum com as populações aborígenes das terras altas do Altai, das terras baixas do Amur e da região de Okhotsk (Ásia). Como os haplótipos estão presentes em diferentes partes da Sibéria, os autores sugerem que os ancestrais americanos são o produto híbrido de diferentes 
grupos siberianos que migraram em diferentes tempos em diferentes rotas. Volodko et al. (2008) também propuseram que os primeiros habitantes do Novo Mundo derivaram das populações da mesma região (Amur/Altai) há aproximadamente 25.000-30.000 A.P.. Contudo, sugeriram que com a alteração climática que pôs fim à era glacial aproximadamente há 11.800 A.P., uma segunda onda migratória deslocaram-se para a Beríngia, originada nas regiões Amur-Mongólia-Manchuria. A manutenção de mais de uma fonte populacional parece ser a melhor solução para a interpretação das linhagens fundadoras de mtDNA dos nativos americanas (Volodko et al., 2008).

Achilli et al. (2008), todavia, supõem que os haplogrupos de mtDNA entraram no Novo Mundo logo após o pico de ocorrência do último máximo glacial (LGM) há 21.000 anos, podendo ter variado de 19.000-23.000 A.P. através de uma rota costeira Pacífica. Uma entrada mais tardia, por volta de 17.000 A.P., originando as populações do extremo norte do continente (Esquimós, Inuits e Na-Denes), deve-se, provavelmente, à uma segunda expansão a partir da Beríngia, logo após o final do LGM. De qualquer forma, nenhuma destas suposições dão suporte a hipótese "Clóvis-frist" (Achilli et al., 2008).

Apenas em 1995 os estudos genéticos voltaram-se para o cromossomo Y. Pena e colaboradores (1995) justificaram o seu uso para a reconstituição de histórias evolutivas por se tratar de uma porção do genoma com polimorfismos haplóides e pela a ausência de recombinação genética. Inicialmente foi identificado apenas um haplogrupo principal fundador americano (Pena et al., 1995; Underhill et al., 1996; Bianchi et al., 1998; Santos et al., 1999). No 
entanto, Karafet et al. (1999) sugeriram a possibilidade de que mais de uma linhagem de haplótipos fundadores de cromossomo $\mathrm{Y}$ teriam entrado na América devido a um contraste nos padrões de distribuição. 0 que implicou, automaticamente, na possibilidade de mais de uma migração parental a partir da região do Lago Baika (Sibéria) e da Mongólia para as Américas (Karafet et al., 1999). A ocorrência de duas grandes migrações originadas da região centro-sul da Sibéria para as Américas também foi proposta em outros estudos, porém com uma segunda migração exclusiva para o extremo da América do Norte (Lell et al. 2002; Bortoloni et al., 2003).

Tarazona-Santos \& Santos (2002) rebateram essa proposta de duas migrações afirmando que apenas uma leva migratória seria necessária para explicar a variabilidade do cromossomo Y no Novo Mundo. Haplótipos raros e por conseqüência, em menor freqüência são esperados em qualquer população, e este seria o caso do haplótipo S4Y e M45b destacado por Lell et al. (2002). A explicação mais parcimoniosa para o haplótipo S4Y é que ele teria chegado à América junto com os demais haplótipos (dado que está presente em baixas freqüências nos nativos americanos). A entrada de outra variante, M45b, teria ocorrido muito posterioremente através do contato com os europeus. Tais suposições reafirmam assim que o povoamento da América foi realizado somente por uma leva migratótia (Tarazona-Santos \& Santos, 2002).

Seielstad et al. (2003) ao considerarem que a variante M-242 surgiu no Velho Mundo antes da entrada dos primeiros humanos na Améria, sendo portanto, uma boa estimativa do limite temporal máximo do homem no continente seria de 14-15.000A.P. (com intervalo de confiança de \pm 1.700 
anos). Vale resaltar que as simulações realizadas por aqueles autores foram baseadas em estimações de parâmetros como taxa de mutação, tamanho populacional e duração de cada geração, que dependendo da combinação escolhida entre essas estimativas, resultou em um amplo espectrum de resultados, variando entre 37.380-12.460A.P., o que demonstra a imprecisão dos parâmetros empregados.

Correlacionando dados provenientes da Genética e da Linguística, Zegura et al. (2004) identificaram os três haplogrupos mais frequentes do cromossomo $\mathrm{Y}$ presentes no continente americano denominando-os de $\mathrm{C}$, Q e R; juntos contribuem para aproximadamente $96 \%$ da diversidade cromossômica indígena. Os haplogrupos fundadores $\mathrm{C}$ e $\mathrm{Q}$ teriam se originado na região das Montanhas Altai, sudoeste siberiano, entre 10.100-17.200 A.P., ao passo que a linhagem $\mathrm{R}$ teria sido trazida pelos europeus. Ambos os haplogrupos ( $\mathrm{C}$ e $\mathrm{Q}$ ) são encontrados nos três grupos lingüísticos de Greenberg et al. (1986). No entanto, o processo de deriva genética poderia ter sido responsável pelas diferenças encontradas nos diferentes componentes geográficos e lingüísticos. Assim, os mesmos chegaram ao Novo Mundo, através de um único evento migratório de uma população fundadora polimórfica originada na região das montanhas Altai. Refutando portanto o "Modelo das Três Migrações" de Greenberg et al. (1986). Por outro lado, Bolnick et al. (2004) ao analisarem o cromossomo Y de 523 nativos americanos, destacam uma não correspondência entre os dados genéticos e a classificação lingüística proposta por Greenberg et al. (1986) adotada por Zegura et al. (2004), sugerindo que outras classificações 
devem ser levadas em conta na distinção dos grupos nativos americanos, principalmente do grupo classificado como Ameríndio.

No intuito de fundir os resultados provenientes dos haplogrupos mitocondriais e do cromossomo Y, Schurr \& Sherry (2004) sugerirem ter havido uma migração inicial originada no centro-sul siberiano que entrou no Novo Mundo entre 20.000-14.000 A.P. e que provavelmente seguiu uma rota costeira, expandindo-se para outras áreas do continente. Essa primeira leva teria trazido consigo os haplogrupos mitocondriais A, B, C e D (e talvez X), os haplogrupos de cromossomo Y P-M45a e os haplótipos Q-242/M3. Uma segunda migração, que poderia ter vindo da mesma região siberiana, entrou na América, possivelmente, por uma rota interiorana, coincidindo com a abertura do corredor livre de gelo por volta de 12.550 A.P., tendo contribuído geneticamente com as populações indígenas do norte e do centro do continente americano. Adicionalmente, populações da Beríngia moveram-se para o norte da América do Norte, depois do último máximo glacial, originando os Aleutas, os Esquimós e os Na-denes.

A partir dos remanescentes esqueletais de um indivíduo datado de 10.300 A.P. encontrado no Alaska (Ilha Príncipe de Gales, Sítio 49-PET-408), Kemp et al. (2007) detectaram um novo haplótipo de DNA mitocondrial fundador americano, do haplogrupo D. O espécime já apresentava o haplogrupo Q-M3* o que coloca uma data mínima de 10.300 A.P. para esta variante. Esse achado tem conseqüências importantes para o povoamento da América. Primeiramente porque demonstra que já houve uma maior diversidade genética no continente do que observada atualmente. Sugerindo que as 
populações nativas atuais não são suficientes para estimar a diversidade genética do passado remoto. Ainda, a necessidade de que a população fundadora seja maior do que anteriormente estimada, já que agora precisa acomodar maior diversidade genética. E finalmente, que os relógios moleculares utilizados até o momento foram mal calibrados (de tradicionalmente $0,1-0,2 \%$ de mutação por sítio por ano, para $0,34-0,44 \%$, ou seja, uma mutação a cada 9.213 anos, mais que o dobro usualmente utilizado).

A maior vantagem de se utilizar DNA antigo como Kemp et al. (2007) é que esse estaria cronologicamente mais próximo e, portanto, estimaria melhor a composição genética dos primeiros americanos. Com taxas de mutação mais altas, os autores, obviamente, sugeriram uma data mais recente para a entrada do homem no continente americano de aproximadamente 13.438 A.P., com intervalo de confiança de 8.113-28.667 A.P., mais condizente com os achados arqueológicos existentes (Kemp et al., 2007).

Diversos trabalhos respaldam o modelo de povoamento da América no qual a Beríngia tem papel capital. A população americana teria inicialmente ali se assentado e apenas em um segundo momento teria se expandido para 0 Novo Mundo (Forster et al., 1996; Bonatto \& Salzano, 1997a; Santos et al. 1999; Saillard et al., 2000; Bortoloni et al., 2002; Derbeneva et al., 2002; Bandelt et al., 2003; Tamm et al., 2007; Volodko et al., 2008; Achilli et al., 2008; Fagundes et al., 2008a). Depois do povoamento da Beríngia, os humanos teriam cruzado o corredor livre de gelo e povoado a América. Esse corredor livre de gelo fechou durante o intervalo de 20.000-14.000 A.P. isolando as populações do sul (que teriam dado origem aos Ameríndios), das populações 
que permaneceram na Beríngia, as quais posteriormente teriam dado origem aos Na-Denes e Esquimós. Isto explicaria a maior proximidade entre os grupos da região ártica do que entre eles e qualquer outro grupo nativo americano, assim como a menor diversidade genética do ártico em relação ao resto do continente.

De forma mais explícita, Bonatto \& Sanzano (1997a) sugeriram o modelo "Out of Beringia" baseado na baixa freqüência de haplótipos A em populações asiáticas e na sua alta freqüencia (81\%) em populações ameríndias. Para eles, seria improvável que diferentes levas migratórias, em diferentes períodos de tempo, carregassem em todas as migrações o mesmo haplótipo com a mesma freqüência. Bonatto \& Salzano (1997b) sugeriram que as populações fundadoras durante a parada na Beríngia sofreram um gargalo populacional seguido de uma grande expansão (para uma visão oposta ver Baillet et al., 1994). A diversidade encontrada nos haplogrupos nas populações indígenas analisadas é muito similar, o que oferece grande apoio a uma origem única, sugerindo ainda que o início da diferenciação das populações ancestrais nativas americanas teria ocorrido por volta de 30.000-40.000 A.P., com limite inferior de 25.000 A.P. para um intervalo de confiança de $95 \%$.

Derbeneva et al. (2002), buscando entender a diversidade das populações beringianas, analisaram o mtDNA dessas populações e propuseram a existência de uma raiz única para o haplogrupo D2 entre as populações árticas ancestrais que deram origem às variantes encontradas nos aleutas (D2b), Na-denes (D2a) e esquimós (D2c). De acordo com Derbeneva et al. (2002) os padrões geográficos observados para o haplogrupo A2 (discutidos 
por Starikovskaya et al., 1998) são espelhados por aqueles do haplogrupo D2. Consequentemente, ambas as linhagens (A2 e D2) são supostos remanescentes do pool gênico inicial das populações costeiras dos primeiros beringianos que persistiram em nessa área geográfica restrita. Estas linhagens seriam, portanto, remanescentes dos primeiros americanos (assentados inicialmente na Beríngia) e não descendentes de uma outra migração como sugerido por Greenberg et al. (1986), apoiando, assim, a teoria do refúgio beringiano (Bonatto \& Salzano, 1997 a e b).

Tamm et al. (2007) sugeriram que a parada na Beríngia ocorreu por tempo suficiente para que mutações específicas ocorressem e separassem as linhagens fundadoras do Novo Mundo das linhagens irmãs asiáticas. A migração inicial do norte para o sul já na América foi um fenômeno rápido e não uma difusão gradual. Essa rápida difusão inicial para áreas não povoadas, foi seguida por um longo tempo de isolamento entre as populações locais que desenvolveram, então, haplogrupos regionais. A diversidade encontrada nos microssatélites específicos na América do Sul corrobora com o suposto isolamento populacional que certos grupos sofreram desde o início do povoamento do continente, sugerindo uma estimativa de aproximadamente 14.000 A.P. para a entrada do homem no Novo Mundo (Bortoloni et al., 2003).

Kitchen et al. (2008) sugeriram um modelo de três estágios para a primeira leva migratória ameríndia que entrou no continente, excluindo assim de seu trabalho as populações da região circum-ártica. De acordo com aqueles autores, teriam ocorrido dois momentos de crescimento demográfico, um primeiro, em aproximadamente em 40.000 AP (período de divergência do pool 
gênico asiático e leve expansão demográfica ao mover-se para a Beríngia) e um segundo, em 15.000AP (com a rápida expansão ameríndia a partir de um efetivo populacional de aproximadamente $1.000-5.400$ indivíduos) separados por um longo período de estabilidade populacional na Beríngia (Kitchen et al., 2008). Bandelt et al. (2003) sugeriram um cenário um pouco diferente, com um aumento populacional massivo e dispersivo já no leste asiático, logo após o surgimento dos haplótipos de mtDNA ancestrais dos haplótipos americanos, entre 35.000-26.000 A.P.. Com a queda da temperatura no LGM, esses grupos residentes na Beríngia poderiam ter sido motivados a deslocarem-se no sentido sul. Bortoloni et al. (2002) sugeriram a existência de um gradiente norte-sul de diversidade genética e de um aumento dos efeitos da deriva genética na América. O que foi confirmado por Wang et al. (2008), já que os nativos americanos apresentam gradientes de decréscimo de diversidade genética em função da distância geográfica em relação ao Estreito de Bering e de similaridade com populações siberianas, indicando o sentido do movimento de dispersão humana no povoamento do Novo Mundo.

Um maior nível de diversidade e um menor nível de estruturação populacional nos ameríndios do oeste do continente em relação as do leste sulamericano favoreceram as hipóteses de rotas terrestres (Wang et al., 2008). Partindo dessa afirmação, o povoamento do continente segundo Wang e colaboradores pode ser mais facilmente explicado por um único evento migratório, com cada passo do processo originando um subgrupo populacional com apenas uma amostra da variação genética existente na população parental. Deste cenário pode-se esperar níveis cada vez menores de 
diversidade com distintos padrões de variação no processo migratório em direção ao sul (Wang et al., 2008).

Com simulações computacionais Bonatto \& Salzano (1997b) sugeriram que o número máximo de mulheres que entraram no continente seria de aproximadamente 2.000 e que o contingente populacional total estaria por volta de 5.000 indivíduos. Aceitando a possibilidade de existirem outros haplogrupos mitocondriais menos bem sucedidos no processo de colonização e que teriam contribuído com aproximadamente $10 \%$ do mtDNA nativo americano, os autores concluiram que esse contingente populacional não teria ultrapassado mais que 10.000 indivíduos. Hey (2005), em contrapartida, sugeriu um grupo com não mais que 80 indivíduos entrando no Novo Mundo. Estes indivíduos, na região da Beríngia, passaram por uma expansão populacional associada com fluxo gênico entre a Ásia e a América. Baseados em taxas de mutação, propuseram que o povoamento teria ocorrido há 7.130 ou há 33.000 A.P., no entanto a data mais antiga foi rejeitada Hey (2005), apesar da inconsistência da data mais recente com as evidências arqueológicas americanas.

Através de estatísticas Bayesianas aplicadas a sequências nucleares, Fagundes et al. (2007) chegaram a conclusões diferentes e sugeriram que a América foi colonizada recentemente, há aproximadamente 10.500 A.P. por cerca de 450 indivíduos. No entanto, os autores destacam que essa cronologia curta para a entrada no continente pode ser resultado em parte da amostra restrita de indivíduos da América Central e do Sul por eles utilizada. Mas, a espectativa dos autores é que mesmo que o povoamento seja mais antigo, ele não superaria o máximo glacial, estando assim mais de acordo com as 
estimativas obtidas do cromossomo Y (14.000 A.P.) do que com os obtidos do mtDNA (30.000 A.P.).

Mais tarde, Fagundes et al. (2008a) analisaram 86 genomas mitocondriais completos e a região do haplótipo $\mathrm{X}$ através de métodos de coalescência Bayesiana, confirmando a hipótese de que apenas uma única onda migratória povou a América por volta de 20.000A.P.. Para eles, a população fundadora teria sofrido uma redução populacional significativa (efeito gargalo de garrafa) - para no mínimo 1.000 mulheres - por volta de 23-19.000 A.P. na Beríngia durante o último máximo glacial. No final do LGM essa população teria passado por uma rápida expansão demográfica que durou de 18.000A.P. a 15.000A.P., confirmando assim, uma ocupação pré-Clovis e um rápido processo de povoamento do continente por uma rota costeira pacífica (Fagundes et al., 2008a), diferentemente do que havia sugerido no trabalho anterior (Fagundes et al., 2007).

Apesar de utilizarem as mesmas técnicas analíticas (Bayesianas), existem diferenças significativas entre os trabalho de Hey (2005) e Fagundes et al. (2008a). Primeiramente, Hey sugere um botlleneck extremo na entrada da América, e Fagundes e colaboradores apenas moderado. A principal discrepância reside, no entanto, na estimativa da data de entrada no continente há aproximadamente 7.000A.P. e há 18.000, respectivamente. A divergência pode ser explicada pelas diferenças nos modelos demográficos utilizados para a simulação, na composição dos dados e nos valores dos parâmetros-chave adotados, dificultando assim comparações mais aprofundadas. 
Szathmary, já em 1993, criticou duramente os trabalhos genéticos e as supostas conclusões retiradas desses estudos para a questão da ocupação do Novo Mundo. Muitos desses pontos foram ainda pouco discutidos na literatura e consequentemente não resolvidos. Szathmary (1993) apontou problemas principalmente quanto aos tamanhos amostrais e no número de locus comumente utilizados. Outro ponto importante destacado pela autora é o foco em apenas um locus para refazer inferências sobre histórias filogenéticas (assim como o uso de apenas segmentos do mtDNA) o que não necessariamente reflete a história de uma população específica já que os efeitos de mutação e deriva genética são aleatórios em um lócus. Szathmary (1993) questionou, consequentemente, a estabilidade das árvores produzidas, principalmente no que diz respeito ao comprimento e à ordem dos ramos. Mais especificamente aos modelos aplicados para a colonização do Novo Mundo, Szathmary (1993) ainda apresentou como problemática a premissa de que a população ancestral seja polimórfica para uma determinada variedade de genes, algum ou alguns dos quais teria sido preservada na população descendente em ambos os lados da Beríngia, usualmente adotada. Para tal afirmação, existe a necessidade de ser validar um equilíbrio de mutação-deriva nas populações modernas nos padrões de mtDNA, para que se possa acessar o mtDNA fundador a partir de populações atuais. Szathmary (1993) destaca a usual e equívoca equivalência adotada entre divergência de haplogrupos e divergência populacional, que na melhor das hipóteses aponta para o limite máximo para uma possível divergência populacional, o que de forma nenhuma 
diz quando que uma determinada população iniciou um processo migratório nem tampouco quando adentrou em uma nova área.

Um estudo genético-molecular extremamente abrangente foi realizado por Eshleman et al. (2003) através da análise de haplogrupos do DNA mitocondrial de populações nativas americanas. Este estudo apresentou resultados contrários aos normalmente defendidos por estudos moleculares, com sérias implicações para a questão do povoamento da América. Dogmas importantes classicamente assumidos foram questionados por Eshleman e colaboradores. O primeiro ponto atacado é que não é possível definir uma localidade asiática como sendo a única fonte da(s) onda(s) migratória(s) fundadora(s) devido a uma não confluência dos haplogrupos a uma única região, sugerindo a necessidade de mais de uma onda e de uma origem migratória. Outro ponto atacado é de caráter teórico-metodológico: sobre quais tipos de inferências são possíveis a partir de dados moleculares. Um bom exemplo é a dificuldade de determinação se a divergência de um haplogrupo ocorreu na Ásia ou no Novo Mundo, muito menos se seria mistura pré ou pósmigração, ou mesmo resultado de ancestralidade comum. Tais questionamentos limitam significativamente o uso do mtDNA para se estimar o período e a duração da migração, o tamanho e a origem da população fundadora, assim como o número de ondas migratórias envolvidas.

Ho \& Endicott (2008) criticaram severamente o que chamaram de "subapreciação da importância das escolhas de calibração" (pg. 142) nos trabalhos de Fagundes et al. (2008a), Achilli et al. (2008) e Kitchen et al. (2008). As estimativas são baseadas nas taxas globais de substituição em humanos e 
chimpanzes, sendo posteriormente extrapoladas para comparações intraespecíficas, o que segundo Ho \& Endicott (2008) seria uma trivialização não crítica e errônea. Ho \& Endicott (2008) reavaliram os resultados de Fagundes et al. (2008a) e de Achilli et al. (2008) com calibrações biogeográficas obtidas a partir de uma árvore humana global. O resultado obtido foi uma substituição por sítio por ano de $2,038 \times 10^{-8}$ com desvio de $2,064 \times 10^{-9}$. Quando aplicada à América a coalescência foi estimada em 13.900A.P., com uma rápida expansão populacional correndo por volta de 10-12.000A.P. associada, provavelmente, à cultura Clóvis (resultados semelhantes aos obtidos por Tamm et al., 2007). Fagundes et al. (2008b), criticaram a estimativa de Ho \& Endocott (2008) por estar baseada em eventos históricos conhecidos de expansão humana (biogeográficos) e, que, portanto estaria superestimando a velocidade de substituição, conseqüentemente subestimando a data de entrada na América.

A diferença de variabilidade entre haplogrupos do cromossomo $\mathrm{Y}$ e do mtDNA encontrado nos diversos estudos apresentados pode ser explicada por diferenças na dinâmica populacional (matrilinear ou patrilinear), pela alta mortalidade masculina caçadores-coletores (diminuindo assim o número de homens no bando) e pela contribuição desproporcional de alguns indivíduos devido à poliginia (Pena et al., 1995; Karafet et al., 1999). A discrepância encontrada entre as estimativas de tempo para o povoamento do continente americano originadas do mtDNA e do cromossomo $\mathrm{Y}$ podem ter diversas causas, entre elas uma maior contração populacional masculina na entrada do continente, diminuindo a diversidade deste cromossomo. Outra causa poderia ser a imprecisão das taxas de mutação, principalmente caso do mtDNA que 
segundo Heyer et al. (2001), parece apresentar taxas de mutação mais altas que os normalmente aceitos.

É bom ressaltar que evidências genéticas geram estimativas de idades máximas, enquanto as arqueológicas, estimativas mínimas (já que raramente o sítio mais antigo é encontrado). De acordo com Fagundes et al. (2008a) existem pelo menos três períodos que podem definir a data do povoamento da América: (i) a colonização da Beríngia, já que parte de seu território é parte do continente americano; (ii) o movimento de saída da Beríngia via costa do Pacífico; e (iii) o povoamento intenso terrestre em direção ao interior do continente. Os dados genéticos apontam para o momento de coalescência dos haplótipos um pouco anterior à colonização da Beríngia, ao passo que os dados arqueológicos têm seus vestígios mais visíveis por volta do terceiro período (Fagundes et al., 2008a). Além disso, polimorfismos gerados por novas mutações geralmente precedem polítipos (populações divergentes) na evolução; portanto, muitas das propostas de povoamentos mais antigos podem não datar de fato as divergências populacionais associadas à formação dos nativos americanos (Zegura et al. 2004).

Em síntese, admitia-se, até bem recentemente, que todas as populações nativas do continente americano, ou pelo menos aquelas hoje ainda representadas, seriam oriundas de uma única região geográfica do nordeste asiático, mais propriamente da Sibéria (e mais precisamente entre a região do Altay e a região de Amur), numa temporalidade entre 10.000-43.000 A.P. (e mais estritamente aproximadamente por volta de 20-25.000A.P.) e que entraram no continente americano em uma única ou poucas migrações 
(carregando 5 haplótipos de mtDNA - A, B, C, D e X - e 2 de cromossomo Y C e Q). No entanto principalmente dos dois últimos anos estudos moleculares vêm apresentando uma maior complexidade na história do povoamento do Novo Mundo. Essa complexidade diz respeito principalmente a maior variabilidade dos primeiros migrantes a entrarem na América do que anteriormente estimado. A necessidade de um assentamento inicial com isolamento geográfico beringiano, com distintas migrações deste assentamento e de episódios de fluxo gênico entre beringianos americanos e asiáticos é a proposta lançada para a variabilidade gênica encontrada. No momento atual, já não é mais possível considerar a entrada do homem no continente americano como um evento de migração simples, direta, de mesma temporalidade e de única fonte popualcional originada na Sibéria, outros eventos são necessários para explicar o povoamneto da América.

\subsection{Os achados Arqueológicos}

Aceitava-se, até recentemente, a idade de 11.400 A.P. como o limite da antiguidade da presença do homem no continente americano, referente aos vestígios da cultura Clovis, encontrados na América do Norte (Fagan, 1999). Nos últimos anos, várias pesquisas arqueológicas vêm produzindo evidências, nem sempre aceitas pela comunidade científica (principalmente a norteamericana), que vêm obrigando os especialistas a examinar de forma mais detida a possibilidade de recuar a temporalidade da ocupação do Novo Mundo.

A cronologia "curta", obedecendo à supremacia Clovis como marco inicial 
das manifestações bioculturais no Novo Mundo, vai ao encontro do "Modelo das Três Migrações" (Turner II, 1983; Greenberg et al., 1986; Turner II, 2002, 2005) para explicar o processo de ocupação pré-histórica da América. O modelo defende que toda o continente América foi ocupado apenas por populações de morfologia mongolóide/sinodonte, oriundas de uma única grande região geográfica, o nordeste asiático, em três levas sucessivas e diferenciadas. Seus proponentes utilizam argumentos biológicos (morfodentários e genéticos) e lingüísticos que foram obtidos em estudos independentes (como relatado por um dos autores Turner II, 2005) que fundidos deram origem ao modelo em questão.

O "Modelo das Três Migrações" assenta-se primordialmente sobre evidências morfológicas dentárias, comparando as características da dentição de populações recentes e pré-históricas do Novo e do extremo oriental do Velho Mundo. Realizando comparações entre nativos americanos, asiáticos e populações do Pacífico, Turner II observou a ocorrência de dois padrões de dentição no extremo oriental do planeta: a Sundadontia e a Sinodontia. A Sundadontia estaria presente em todo o Pacífico sul e na Ásia meridional (indonésios, javaneses, atayals e jomoneses do Japão). Na região norte da Ásia, entre os chineses, siberianos, mongóis e japoneses (exceto Jomon), ocorreriam características dentárias mais complexas, derivadas da Sundadontia, a Sinodontia (Greenberg et al., 1986; Hillson, 1996; Turner II \& Bird, 1981; Turner II, 1983, 1990, 2002, 2005).

Segundo Turner II, os nativos americanos apresentam, de maneira generalizada, o padrão Sinodonte, concluindo assim que as populações do Novo 
Mundo têm como ancestrais aquelas que se desenvolveram no norte/nordeste asiático no final do Pleistoceno. Observou, ainda, que pequenas alterações ocorreram ao longo dos últimos 11.000 anos, o que o levou a classificar o padrão sinodôntico em três grupos: o Ameríndios, o dos Nadenes e o dos Esquimós-Aleutas, cada qual com uma história evolutiva particular. Os Ameríndios, em sua maioria, teriam, sob sua ótica, partido do vale do rio Lena, na Sibéria, há cerca de 14.000 A.P.. Numa região ao sul desse vale, encontrarse-ia o ponto de partida dos Nadenes, que teriam cruzado a Beríngia há cerca de 10.000 A.P.. E, finalmente, a partir da bacia do rio Amur, teriam partido os proto-Esquimós-Aleutas, há cerca de 5.000 A.P. (Greenberg et al., 1986; Turner II, 1983, 2002, 2005). Para ele, essa seria a explicação mais parcimoniosa para a ubiquidade da morfologia sinodôntica nas Américas (Greenberg et al., 1986; Turner II, 1983; Turner II \& Bird, 1981). De acordo com suas suposições, estudos sobre o povoamento da Beríngia afirmavam que a mesma teria sido povoada em resposta a mudanças climáticas no final do Pleistoceno, por volta de 12-11.000A.P., e só então teria sido possível a entrada na América (e.g. Meltzer, 1989; Hoffecker et al., 1993; Goebel, 1999; Goebel et al., 2003).

Apesar de ampla aceitação, vários pontos contrários têm sido levantados em relação ao "Modelo das Três Migrações" de Turner II e colaboradores. Do ponto de vista das análises morfológicas dentárias a metodologia adotada sofreu críticas, devido à sua alta complexidade e difícil replicabilidade (Powell, 1993). A disparidade amostral, ou seja, a comparação entre grupos com amostras grandes e grupos com amostras extremamente reduzidas também tem sido criticada (Szathmary, 1986). Estudando esqueletos Paleoíndios e 
Arcaicos norte-americanos, Powell (1995) demonstrou, por exemplo, não ser possível classificá-los como sinodontes, seguindo-se o método proposto por Turner II (1983). A análise de Haydenblit (1996) mostrou resultados semelhantes aos de Powell, porém para esqueletos tardios da América Central. Um estudo realizado com populações esqueletais do período arcaico andino, mostrou ser impossível reduzir a variabilidade de todas as amostras envolvidas ao padrão sinodôntico (Sutter, 1997).

Do ponto de vista lingüístico, diversos autores (Campbell, 1988, 1997; Goddard, 1987, 1990, 1996; Mithun 1990; Goddard \& Campbel 1994; Nichols, 1997) discordam da metologia embregada na classificação do grupo Ameríndio de Greenberg et al. (1986), já que diversos pontos são desconsiderados - como similaridades devido a proximidade filogenética, a proximidade geográfica e contatos entre outros. De forma mais ampla, Meltzer (1989), afirma que por mais que a classificação tripartite de Greenberg et al. (1986) esteja correta ela não pode ser utilizada como evidência para se estimar o número de migrações já que diferentes migrantes durante milhares de anos podem ter falado línguas relacionadas, iguais ou diferentes. Além disso, os processos pelo qual os sistemas genéticos e lingüísticos são correlacionados com materiais arqueológicos são no mínimo altamente especulativos. Meltzer (1989) afirma que suposições baseadas em populações atuais após 12.000 anos do evento em questão correspondem somente à uma parcela migratória bem sucedida de todos esses anos e, conseqüentemente, a questão dos primeiros americanos deve estar alicerçada fortemente em dados arqueológicos.

Pesquisas arqueológicas desenvolvidas no final do século XX também 
vêm questionado o modelo "Clovis-frist" (Roosevelt et al. 2002, Lovgren, 2003; Bradley \& Stanford, 2004; Stanford et al., 2005; Prous, 2006). Datações estabelecidas entre 16.000 e 14.000 anos A.P. para os sítios de Meadowcroft, na Pennsylvania (Adovasio et al., 1998), Topper, na Carolina do Sul (Goodyear, 1999) e Cactus Hill, na Virginia (McAvoy et al., 2000), além de algumas ocorrências encontradas no Texas (Collins, 2002) são obviamente, mais antigas do que aquelas atribuídas aos sítios da cultura Clovis, forçando uma reavaliação sobre os limites temporais da entrada humana no continente. Recentemente, uma revisão com técnicas mais precisas (AMS) das datações de sítios Clovis realizada por Walters \& Stafford Jr. (2007), atribuiu idades ainda mais recentes para tal cultura. As novas datas, 11.050 A.P. e 10.800 A.P., reduziram o início da cultura Clovis em 450 anos e anteciparam o seu término em 100 anos. As novas datas fortalecem a idéia de que outras culturas fundadoras existiram na América, pelo menos ao mesmo tempo que Clovis. Estima-se que para o homem ter se estabelecido no extremo sul do continente há 12.000 anos, seria necessário recuar a chegada dos primeiros paleoíndios ao extremo norte da América para, pelo menos, 14.000 A.P. (Dillehay, 2003).

Na América do sul, a arqueologia também vem reunindo evidências tecnicamente bem fundamentadas para contestar o modelo "Clovis-first". É o caso do sítio arqueológico de Monte Verde, no Chile, ocupação inquestionavelmente humana de pelo menos 12.300 A.P. (Dillehay, 1997; Meltzer et al., 1997). Outro extrato mais antigo, de paroximadamente 33.000A.P., chamado MV-I, em Monte Verde é extremamente questionado. No entanto, pode retrocer consideravelmente a ocupação do continente americano 
caso seja aceito pela comunidade científica no futuro (Dillehay, 1997). Vale destacar que a ocupação mais aceita de Monte Verde, MV-II de aproximadamente 12.800-12.300A.P., não se trata de um acampamento de caçadores especializados em megafauna, mas sim de um assentamento de uma população com variadas e flexíveis estratégias de subsistências variadas e fexiveis, ou em outras palavras, caçadores-coletores generalistas (Dillehay, $1997,2000,2004)$.

A contemporaneidade de alguns sítios sul-americanos com a cultura Clovis como, por exemplo, Cerro Três Tetas, Cueva Casa del Mineiro e Pietra Museo, na Argentina (com datas de $10.560 \pm 140$ A.P., $10.999 \pm 55$ A.P. e

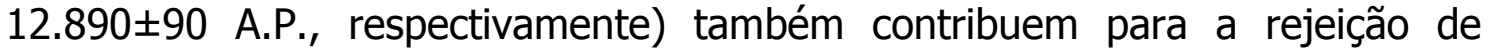
Clovis como a mais antiga ocupação humana no continente americano (Miotti \& Salemme, 2003).

Algumas outras evidências mais ousadas para a presença do homem no continente americano também têm sido geradas na América do Sul, porém não colheram muito crédito junto à comunidade científica, devido à sua discrepância em relação aos demais achados. Um exemplo é o trabalho de Guidon \& Delibrias (1996) no sítio Boqueirão da Pedra Furada, no Parque Nacional da Serra da Capivara. Artefatos líticos encontrados em estratos datados em até 35.000 A.P. e diversos carvões associados a supostas fogueiras da camada mais basal do sítio foram datados e resultaram num intervalo de 56-41.300A.P. recuando significativamente o povoamento do continente. Outro exemplo também do Parque Nacional da Serra da Capivara vem da Toca da Bastiana, onde uma fina camada de calcita que cobria uma pintura foi datada por 
termoluminescencia em 35-43.000A.P., sugerindo que os humanos já estariam vivendo na região anteriomente a 35.000A.P. (Guidon et al., 2003). Além dos achados de Guidon em sítios brasileiros, as datações mais antigas do sítio de Monte Verde de aproximadamente 33.000A.P., também com sua suposta origem antrópica severamente criticadas, recuariam a entrada do homem no continente americano consideralvelmente (Fagan, 1999; Prous, 1997 e 2006).

Recentemente, escavações realizadas na região do vale do Rio Aldan, na Sibéria, dobraram a temporalidade da presença humana na região, alcançando 27.000 A.P. (Pitulko et al., 2004), o que potencialmente permitiria uma entrada na América anterior à geralmente aceita. Tal descoberta ainda não é suficiente para dar suporte às estimativas mais recuadas, mas abre precedentes para a possibilidade de descoberta de novos indícios da presença humana mais antigos no Novo Mundo. Mesmo assim, a data de chegada dos primeiros americanos continua sob intenso debate na comunidade científica especializada, indicando uma ausência de consenso entre os pesquisadores.

As comparações das indústrias líticas da América do Norte com as do Sul também questionam uma suposta continuidade cultural através de uma dispersão linear e homogênea a partir da cultura Clóvis para os paleoíndios da América do Sul (Dillehay, 1999; Dixon, 2001). As primeiras tradições culturais americanas, Nenana, Paleoíndia e Denali, não dão suporte à hipótese tradicional de povoamento pelo interior da Beríngia, envolvendo caçadores especializados em mega-fauna por volta de 11.200 A.P. (Dixon, 2001). A semelhança encontrada entre as indústrias líticas dos complexos Clóvis e Nenana e suas associações com caça de grandes mamíferos (Powers \& 
Hoffecker, 1989; Dixon, 1999) pode sugerir que ambas derivam de uma cultura ancestral comum (Dixon, 1999).

Evidências arqueológicas, como Monte Verde no Chile, demonstram a presença de populações e tradições culturais pré-Clóvis, assim como especializações regionais no perído 12-11.000A.P., portanto, já adaptadas aos seus ambientes o que vai contra a supremacia Clóvis (Dillehay, 1999; Dixon, 2001; Roosevelt et al., 2002). Portanto, segundo Dixon (2001), de uma perspectiva tecnológica, parece existir dois eventos principais de colonização da América. O primeiro com os ancestrais dos complexos Clóvis e Nenana, antes de 11.500A.P., possivelmente por volta de 13.500A.P., e uma segunda leva migratória trazendo a tradição americana Arcaica por volta de 10.500A.P., introduzindo o arco e a flexa, e o arpão (Dixon, 2001).

Dillehay (1999) defende que a diversidade ambiental permitiu uma ampla variedade de possibilidades na exploração de recursos naturais na América do Sul (conseqüência direta de um menor impacto da glaciação), o que teria fomentado uma maior diversidade de culturas do que as encontradas na América do Norte (caçadores especializados em grandes mamíferos representados pela cultura Clóvis). Indústrias líticas unifaciais e bifaciais extremamente variadas são amplamente e concomitantemente encontradas em sítios da América do Sul por volta de 11.000A.P., o que não ocorre na porção norte do continente. Para explicar essa diferença, Dilehay (1999) sugeriu que na porção norte do continente teria existido maior contato entre as populações nas áreas marginais (onde existe evidência da cultura Clóvis) num período inicial do povoamento, e que na porção sul do continente, teria existido um 
maior nível de adaptação local sem contato entre as populações migrantes. Este contato já no início do povoamento da América do Norte explicaria a rápida dispersão da tradição cultural Clóvis nesta porção do continente. As adaptações locais envolvendo menor mobilidade e, portanto, novas estratégias para lidar com um ambiente sazonal, com variações imprevisíveis e provavelmente com territórios fixos e limitados poderiam ajudar a explicar a diversidade amplamente dispersa da indústria lítica na América do Sul (Dillehay, 1999, 2000).

No Brasil, intervenções arqueológicas também têm gerado um crescente número de evidências de antiguidades iguais ou superiores às atribuídas aos sítios Clovis. Bons exemplos são a Caverna da Pedra Pintada, na Amazônia, datada em cerca de 11.300 A.P. (Roosevelt et al. 2002); Lapa Vermelha IV, Lagoa Santa - MG, cujo fóssil conhecido popularmente como Luzia foi encontrado em estrato arqueológico entre 11.000-11.500 A.P. (Neves et al., 1999); Santana do Riacho, Serra do Cipó - MG, com datações de $11.960 \pm 250$ A.P. dos vestígios de uma grande fogueira (Prous, 1992); Lapa do Boquête, Vale do Peruaçu - MG, cujo nível arqueológico mais antigo foi datado em 12.070 070 A.P. (Prous, 1992); Toca dos Coqueiros, Serra da Capivara - PI, com sepultamento humano datado em $9.870 \pm 50$ A.P. (Hubbe et al., 2007); Toca do Garrincho, Serra da Capivara - PI, com vestígios humanos fossilizados

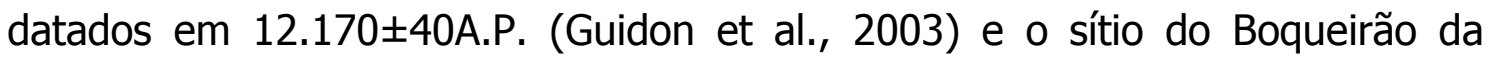
Pedra Furada, Serra da Capivara - PI, com estratos arqueológicos contendo supostos artefatos líticos com pelo menos 35.000 anos A.P. (Guidon \& Delibrias, 1996). Este último tem tido, no entanto, sua suposta origem antrópica 
extremamente criticada (Fagan, 1999; Prous, 1997, 2006). A data da chegada dos primeiros humanos ao Novo Mundo continua, portanto, sob intenso debate.

Outra questão complexa sobre a entrada do homem na América resvala nas condições climáticas sob as quais o evento ocorreu. Estudos paleoclimáticos na região pela qual teria sido mais provável a entrada humana, a Beríngia, tem contribuído muito para o debate. Este é o caso dos estudos de Hoffecker et al. (1993) e Hoffecker \& Elias (2003) que afirmam que a região era extremamente seca e fria durante o período em questão, o último glacial máximo entre 21.000 a 18.000 A.P.. Durante este período grande parte da água estava armazenada sob a forma de gelo e o nível do mar estaria mais baixo (aproximadamente $120 \mathrm{~m}$ mais baixo que atualmente), o que teria exposto uma grande extensão de terra denominada Beríngia, que ligou o continente asiático ao americano (Hoffecker et al., 1993; Hoffecker \& Elias, 2003). No entanto, o povoamento da Beríngia estaria extritamente condicionado às mudanças climáticas, provendo recursos necessários à passagem humana a partir de 25.000 A.P. (a partir de 60.000A.P. o nível do mar já estaria aproximadamente 50 metros mais baixo, expondo grande parte da Beríngia). Esta "janela" desapareceu por completo por volta de 10.000A.P. com a total submersão da região pela elevação do nível do mar (Hoffecker et al., 1993).

O que nunca ficou esclarecido totalmente é se a presença da ponte de terra, a Beríngia, teria sido crítica ou não para a ocupação do Novo Mundo, já que durante todo o Holoceno caçadores-coletores moveram-se livremente pelo Estreito de Bering (Hoffecker et al., 1993). O entendimento do paleoclima da Beríngia é indispesável, tendo em vista que as condições climáticas que 
determinam seu aparecimento e desaparecimento, tiveram ação direta nas condições ambientais tanto no interior, quanto na costa (Hoffecker et al., 1993).

A descoberta do sítio Yana RHS na Sibéria datado de 28.000A.P. demonstrou que os humanos já estavam adaptados a condições climáticas extremas (Pitulko et al., 2004). Estudos paleoclimáticos como o de Brubaker et al. (2005) propuseram que a Beríngia, durante o Último Máximo Glacial, era composta por um mosaico de vegetações, que sobreviveram a condições climáticas extremas, em refúgios locais. Análises sobre a diversidade de fungos demonstram que a Beríngia foi mesmo um refúgio para vegetações com maior diversidade que as das regiões polares; consequentemente, teria sido possível sustentar diversas populações animais inclusive de megafauna, apesar das drásticas mudanças climáticas (Lydolph et al., 2005). Portanto, essa extensão de terra, apesar de composta por diferentes biomas, todos frios e secos, teria possibilitado a travessia humana para o Novo Mundo (Pavlov et al., 2001).

Outra idéia muito debatida, neste contexto, é a passagem dos primeiros desbravadores americanos pelo Corredor Livre de Gelo que teria permito uma rápida dispersão dos pioneiros pelo continente recém alcançado (Bryan, 1969; Reeves, 1973) (Figura 01). Tal possibilidade apóia a idéia de uma entrada mais tardia no continente, entre 14.000 e 11.400 A.P, em concordância com o modelo Clovis-first. Os defensores da proposta advogam que os primeiros povoadores teriam seguido animais de grande porte por esse corredor rumo ao sul; porém, não há evidências que sustentem essa possibilidade. A dispersão no continente americano de populações caçadoras especializadas em grandes 
maníferos através do suposto corredor livre de gelo tornou-se um dogma na literatura sobre o povoamento da América, inviabilizando assim qualquer outra possibilidade de rota alternativa para o evento (Fladmark, 1979; Mandrik et al., 2001; Bradley \& Stanford, 2004; Stanford et al., 2005).

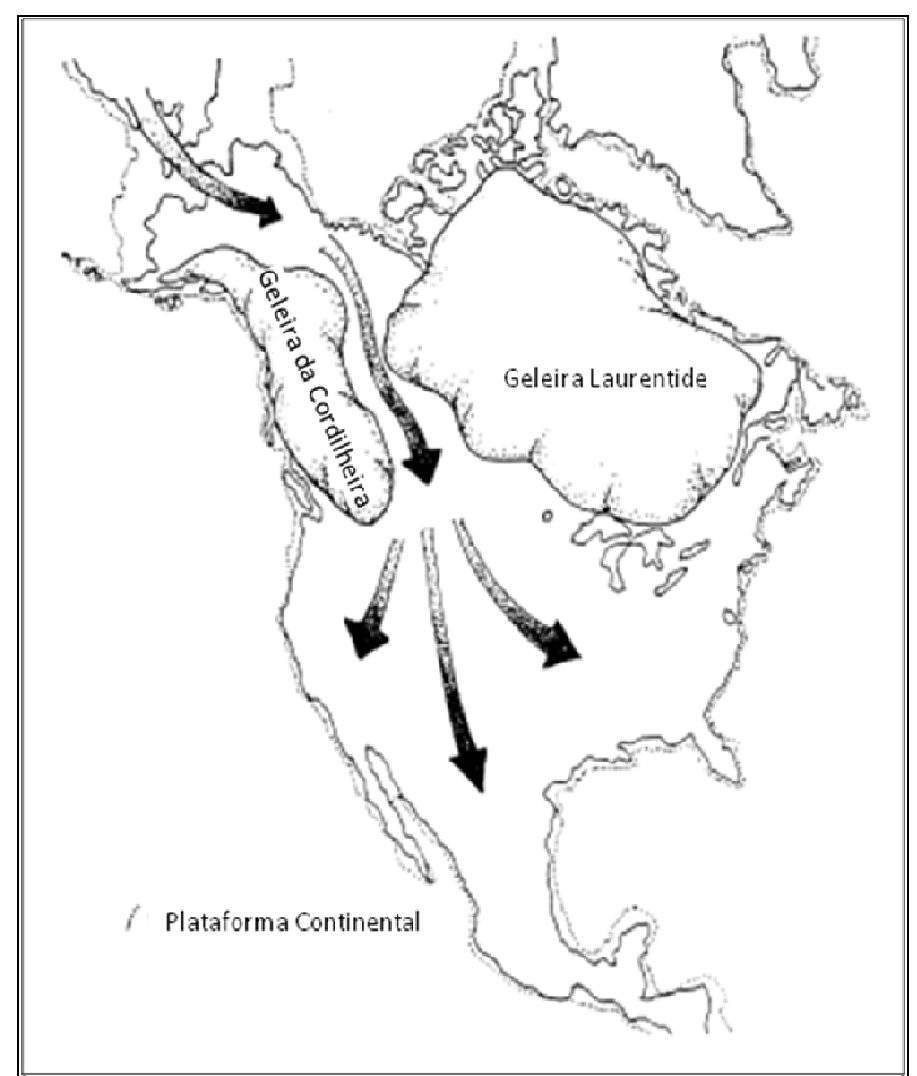

Figura 1 - Representação gráfica da suposta rota pelo Corredor Livre de Gelo utilizado pelos primeiros americanos por volta de 11.500A.P.. Extraído de Dixon, 2001.

As principais críticas recaem mais sobre a viabilidade ecológica de tal corredor do que sobre sua suposta existência. Ou seja, mesmo que o corredor existisse, qual seria a viabilidade de sobrevivência de populações tanto humanas quanto animais nesse espaço recém criado e por conseqüência inabitado e inóspito (Fladmark, 1979; Mandriki et al., 2001; Elias, 2001)? Seus defensores argumentam de forma indireta baseados em ausências de evidências para fundamentarem suas idéias afirmando que a abertura tardia do 
corredor não seria um problema já que não existe evidência inquestionável da presença humana no continente antes de 12.000A.P.. Da mesma forma, a ausência de evidências de que os primeiros migrantes tivessem o domínio da navegação para evitar a rota terrestre tradicional tonando o corredor a melhor opção (Yesner, 2001). E, baseados em dados polínicos argumentam que a região seria aparentemente um bom habitat para rebanhos de bisões, alces e aves aquáticas, presentes no registro fóssil por volta de 12.000A.P., e consequentemente para as popualções humanas (Yesner, 2001).

Apesar disso, alguns pesquisadores defendem uma rota costeira para a entrada e a dispersão inicial do homem no novo continente. Porém, conforme já foi salientado esta hipótese é de difícil constatação já que os eventuais vestígios desta suposta ocupação são inacessíveis aos arqueólogos, pois estariam atualmente submersos (Fladmark, 1979; Dillehay, 1999; Dixon, 2001; Fix, 2002; Kelly, 2003). De qualquer forma, a rota costeira Pacífica parece se enquadrar mais apropriadamente nas evidências geológicas e arqueológicas atuais do que o antigo consenso sobre uma rota pelo corredor livre de gelo (Elias, 2001; Mandrik et al., 2001).

O primeiro trabalho a chamou a atenção para a via costeira foi o de Fladmark (1979), que estava preocupado com a viabilidade das possíveis rotas de entrada na América durante o período glacial. Indícios de regiões costeiras continentais e de ilhas marítmas livres de gelo densamente ocupadas por mamíferos marinhos apoiam a viabilidade geo-biológica costeira para sustentar populações humanas no final do Pleistoceno (Fladmark, 1979). 
Os dois argumentos centrais que favorecem a teoria da rota costeira são os achados arqueológicos de Dillehay (1997) em Monte Verde, Chile, datados de pelo menos 12.300 A.P.; e, o fato do corredor livre de gelo só estaria aberto por volta de 12.400A.P.. Aceitando a antiguidade de Monte Verde fica óbvio que a data da abertura do corredor livre de gelo não condiz com a entrada nas Américas (Elias, 2001; Mandrik et al., 2001). Mandrik et al. (2001) afirmaram que a aceitação de Monte Verde não só questiona a data da entrada do homem na América, como também questiona o Modelo "Clovis-first" como um todo, concordando assim com Dixon (2001) e Dillehay (1999) a respeito da diversidade da indústria lítica das primeiras populações americanas. Além de uma indústria lítica mais diversificada, é também defendida uma adaptação a ambientes e recursos marinhos por parte dos primeiros migrantes (Faldmark, 1979; Dillehay, 1999; Dixon, 2001; Mandrik et al., 2001). Dillehay et al. (2008) ao analisar sedimentos marinhos na suposta rota costeira encontrou nove espécies de algas associadas a três instrumentos líticos datadas de 14.000 A.P., indicando assim que esses primeiros habitantes faziam uso dessas algas como medicamento, corroborando desta forma a idéia de familiaridade com recursos costeiros (Dillehay et al., 2008).

Segundo Dixon (2001) a cronologia da última glaciação estabelece limites míninos e máximos para a entrada do homem no Novo Mundo. A deglaciação da porção noroeste da costa da América do Norte estava em um estágio suficientemente avançado há pelo menos 13.000A.P.. No entanto, o interior da Beríngia e a rota pelo interior do continente não estavam livres de gelo antes de 11.000A.P. (Dixon, 2001). Vastas áreas ao longo da costa já 
poderiam estar livres de gelo por volta de 16.000A.P., assim como durante todo o período final do LGM, entre 13.500-9.500A.P. (Dixon, 2001). Yokoyama et al. (2000) sugeriram que o pico no volume máximo de gelo que ocorreu entre 2219.000A.P.. Da mesma forma, ocorreu um rápido decréscimo deste volume, por volta de $10 \%$ em poucas centenas de anos, encerrando o LGM por volta de 19.000 $250 A . P .$.

Dixon (2001) sugeriu que o povoamento de grandes áreas, como é o caso do continente americano, seja visto sob a perspectiva de macro-zonas ambientais ou biomas (Figura 02). Defende ainda a hipótese de que as zonas de ecótonos (limite entre biomas ou ecofisionomias) seriam as regiões que permitiriam maior acesso a recursos naturais diferenciados. Entendendo a região costeria americana como sendo um único bioma, é possível supor que o deslocamento pode ter sido bastante rápido ao longo de uma extensão considerável, do extremo norte do continente a seu extremo sul, já que a população migrante não teria que se adaptar a um novo ambiente para se expandir (Dixon, 2001; Kelly, 2003). Regiões costeiras são consideradas regiões ricas em recursos já que tanto recursos aquáticos e terrestres (tanto caça quanto coleta) podem ser acessados (Fladmark, 1979; Dixon, 2001; Mandrik et al., 2001). Neste sentido, tanto as regiões marítmas costeiras quanto as ribeirinhas seriam ótimas alternativas para explicar porque a América sofreu um processo de povoamento tão rápido (Fladmark, 1979; Dixon, 2001; Mandrik et al., 2001; Kelly, 2003). Além disso, evidências geológicas indicam que partes do litoral da Columbia Britânica estavam livres de gelo durante o período Wisconsiniano tardio (c.a 40.000 a 10.000A.P.) o que teria permitindo o acesso 
a recursos costeiros e terrestres (Mandrik et al., 2001). A travessia seria possível pela navegação de cabotagem, margeando trechos litorâneas de terra expostos pela redução do nível do mar (Hoffecker \& Elias, 2003).

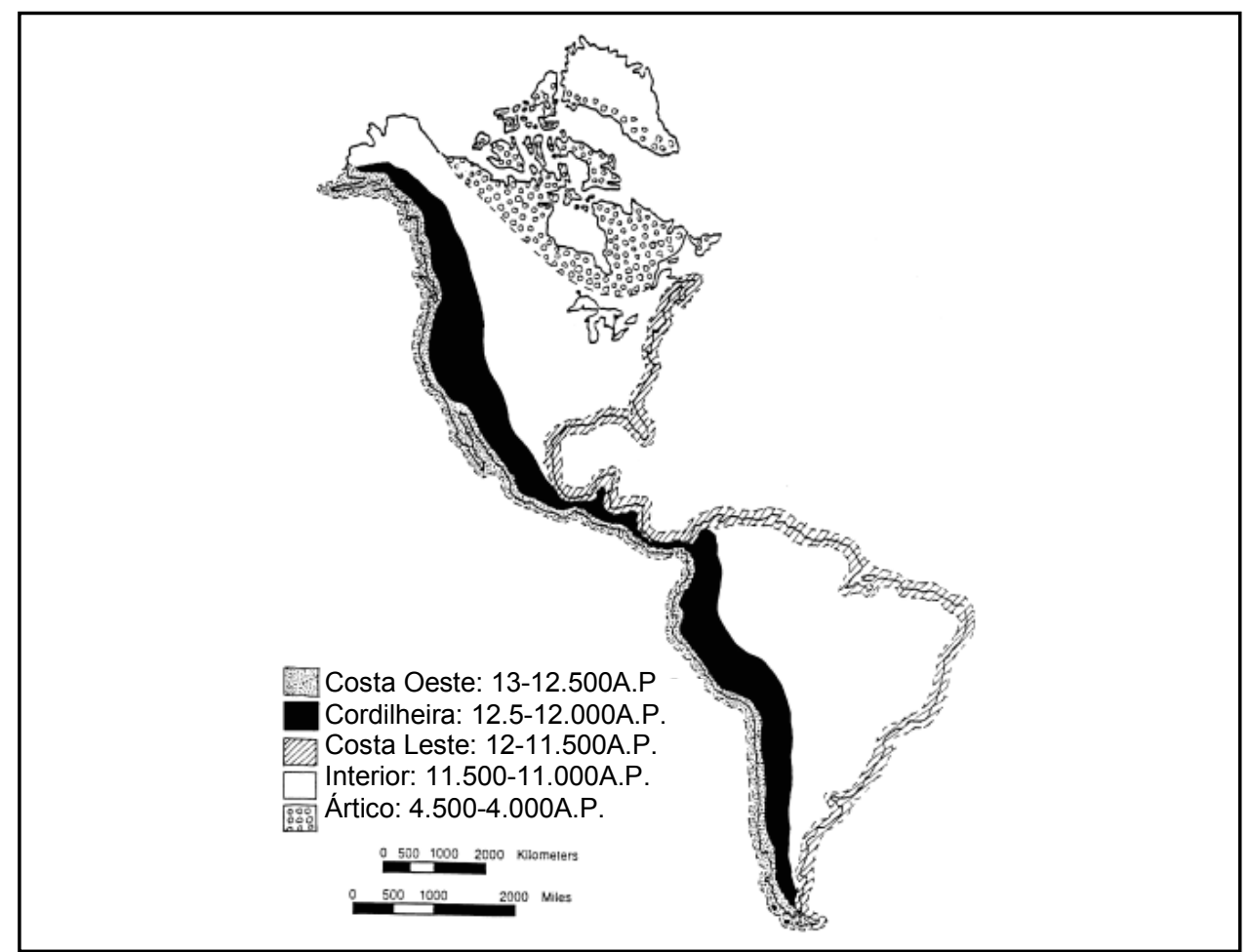

Figura 2 - Representação esquemática de como poderia ter ocorrido o povoamento das Américas ao longo das zonas ambientais por volta de 13.000A.P. proposta por Dixon (2001). Extraído de Dixon (2001).

Dixon (2001) formalizou o modelo litorâneo assumindo uma entrada por volta de 14-13.500A.P. ao longo da costa pacífica da Beríngia e da América (Figura 03). Segundo ele, a migração costeira acontecou de forma bastante rápida, já que os migrantes não tiveram que se adaptar a novos ambientes para se re-expandir (se mantiveram dentro de um mesmo bioma) (Dillehay, 1999; Dixon, 2001; Kelly, 2003). A cultura material desses migrantes costeiros deve ter sido baseada em madeiras, ossos marinhos, conchas e seixos dificultando, assim, a visibilidade desses vestígios arqueológicos (Dixon, 2001; 
Kelly, 2003). Uma indústria lítica sofisticada provavelmente não seria importante nesses ambientes costeiros (Dixon, 2001).

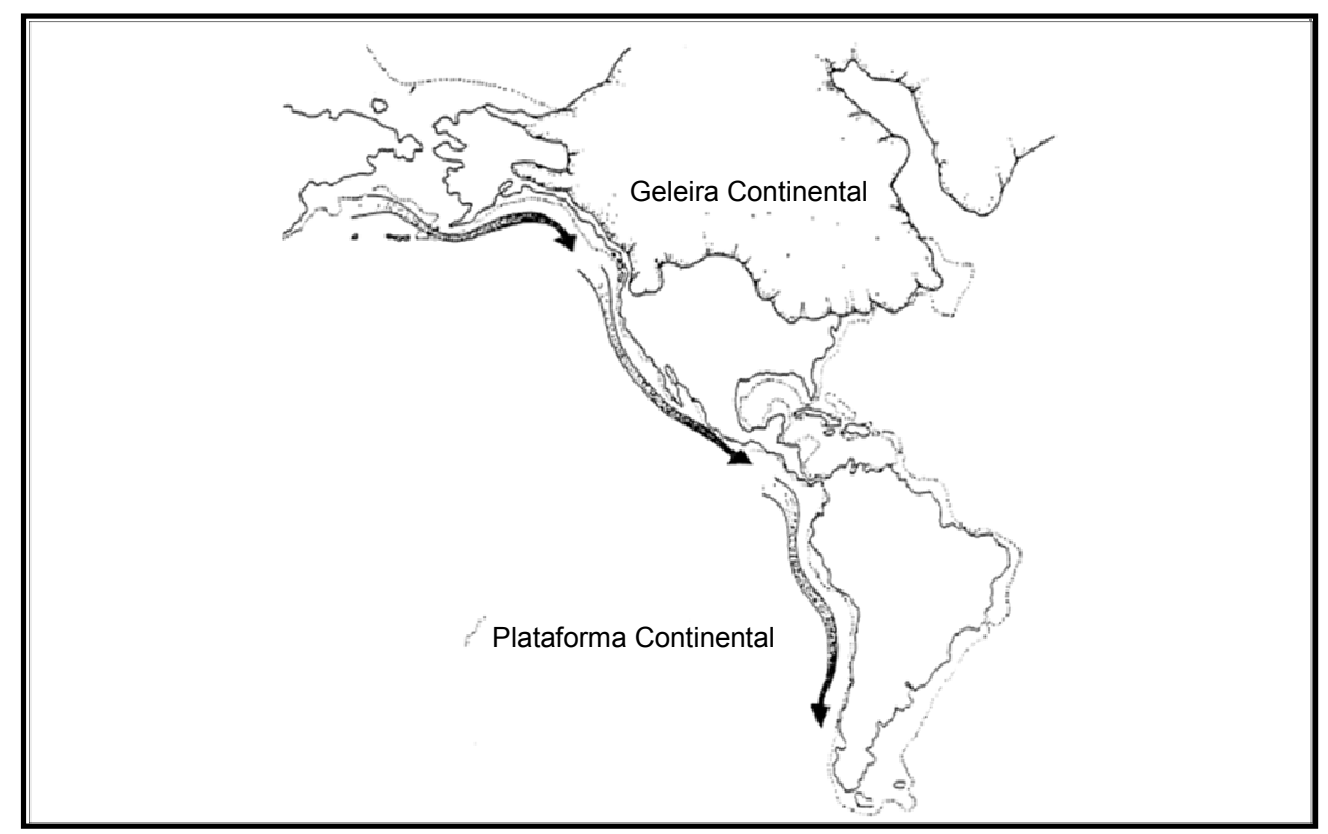

Figura 3 - Representação gráfica da suposta rota costeira utilizada pelos primeiros americanos sugerida por Dixon. Extraída de Dixon (2001).

Dilehay (1999) sugeriu que uma vez na América do Sul, a primeira leva dispersou-se rapidamente para várias áreas, facilitada por uma rica rede hidrográfica que já em 14-12.500A.P. estava disponível e se isolaram em pequenos grupos adaptando-se a ambientes terrestres (Fladmark, 1979; Dixon, 2001). Neste cenário, as planícies do leste teriam sido uma das últimas áreas a serem povoadas, tendo em vista ser assim como seria uma das menos ambientalmente hospitaleiras do continente. Cada grupo local inicialmente teria uma alta mobilidade, mas apenas dentro de uma zona ambiental limitada (por ex. savanas ou florestas) grande o bastante para sustentar o macro-grupo (Dilehay, 1999). Ainda de acordo com Dixon (2001) uma segunda leva migratória teria trazido a cultura Clóvis por volta de 11.000A.P. para a América do Norte, ao passo que a América do Sul parece não ter experimentado um 
fluxo continuo de imigrantes no mesmo período (Dilehay, 1999). Consequentemente, o complexo Clóvis, seria muito mais uma especialização cultural, tecnológica e ecológica específica durante o Pleistoceno. Ele poderia podendo ser considerado o mais antigo representante do povoamento do interior da porção leste norte-americana, mas não a mais antigas das Américas (Dixon, 2001; Roosevelt et al., 2002).

Para tentar esclarecer a questão da rota migratória, Fix (2002), através de simulações computacionais, testou os dois modelos, via interior e via costa, estabelecendo limitações populacionais de crescimento e mobilidade. Para a entrada pelo interior, seria necessária uma rápida dispersão, perda de variabilidade genética e a passagem entre duas geleiras (corredor livre de gelo) na porção norte do continente, o que só seria possível por volta de 11.000A.P.. Dito isso, uma fixação quase completa da variabilidade atual nativa americana ( $82 \%$ dos loci) seria estabelecida em aproximadamente 20 gerações, a partir de uma população fundadora de 100 indivíduos com uma taxa de crescimento de 3.4\% ao ano. Em outras palavras, a população duplicaria de tamanho a cada 20 anos. Assumindo-se a velocidade de 16 quilômetros por ano, 94\% da variabilidade genética seria perdida em apenas 750 anos, tendo como conseqüência uma grande homogeneidade dentro da população nativa americana.

Já a via costeira, tal como simulado por Fix (2002) implicaria em um quadro menos extremos, com um povoamento mais lento, com maior abundância de recursos, sem saturação populacional, implicando em menor perda da variabilidade genética (sem fixação de nenhum loci e com todas as 
populações mantendo a variabilidade genética inicial até 100 gerações). Este quadro parece aproximar-se mais da realidade, levando-se em consideração as informações disponíveis até o momento geradas por dados genéticos, arqueológicos, ambientais e morfológicos (Fix, 2002; Surovell, 2003; Kelly, 2003; Jantz \& Owsley, 2005).

Surovell (2003) contestou seriamente o modelo de migração costeira, com os parâmetros estimados, já que segundo Surovell este não abarca todas as discrepâncias existentes entre os sítios norte-americanos e Monte Verde. Isso porque é muito difícil explicar a chegada do homem em Monte Verde antes da expansão dos nativos norte-americanas da costa para o interior. Portanto, é necessário que outras informações sejam incorporadas às simulações para explicar essa discrepância entre as datas de ocupação dos sítios supra citados, já que a rota migratória pelo litoral por si só não seria capaz, de acordo com Surovell (2003).

Atualmente ex-defensores da supremacia Clóvis, como Goebel et al. (2008) revisaram suas antigas suposições e aceitam que os humanos já estariam adaptados a condições extremas de frio por volta de 32.000A.P., fenômeno apoiado nos achados de Yana RHS na Sibéria. Adimitem também a possibilidade de que os humanos já estivessem presentes na Beríngia por volta de 28.000A.P.. Goebel e colaboradores sugeriram também que desde 40.000A.P. as geleiras que cobriam o Canadá sofriam variações em sua extensão, criando assim corredores livres de gelo na costa do Pacífico e na planície a leste das Rochosas canadenses. Dito de outra forma, desde que os humanos colonizaram a Sibéria, teria sido possível uma migração humana para 
a América. Esta "janela" temporal extendeu-se pelo menos até 24.000A.P., quando se deu uma re-expansão das geleiras arratetando o fechamento de possíveis corredores livres de gelo.

Goebel et al. (2008), adimitiram que só não seria possível uma entrada nas Américas anteriormente há 40.000A.P., desafiando a supremacia Clóvis. Por fim, sugeriram que a variação genética atual dos nativos americanos não é condizente com uma entrada tardia do homem no continente; uma visão extremamente diferente da estabelecida pelo "Modelo das Três Migrações" (Greenberg et al., 1986) e defendida por Goebel (1999) e Goebel et al. (2003). Essa alteração de paradigma das interpretações dos dados arqueológicos vem de encontro a atual mudança existente no campo da Biologia Molecular, que tras a tona a necessidade de re-leitura do processo de colonização do continente americano.

\subsection{Antropologia Biológica}

\subsubsection{A craniologia dos primeiros americanos}

Os primeiros habitantes do Novo Mundo causaram interesse nos europeus desde os primeiros contatos relatados com esses povos. Mesmo nos primeiros relatos documentados, as semelhanças fenotípicas dos nativos americanos com povos mongolóides foram apontadas. O trabalho de Morton (1839) intitulado "Crania Americana" pode ser considerado o início dos estudos craniométricos dos nativos americanos influenciando e orientando diversos 
trabalhos posteriores (para uma revisão ver Fagan, 1999). Naquele momento, a Antropologia Física era tipológica e racialista, hierarquizando raças e classificando-as em desenvolvidas e sub-desenvolvidas. Tal vertente sofreu ataques severos pela vertente culturalista da Antropologia, liderados por Frans Boas (1912).

Entre os estudos de Antropologia Física que abordaram a questão da origem dos nativos americanos maior destaque é dado aos trabalhos de Aleš Hrdlička (1907, 1912, 1932). Hrdlička (1912) definiu o "homótipo americano" baseado em características físicas, sugerindo assim, uma grande homogeneidade entre os índios americanos e uma origem única asiática para todos eles. Em 1912, Hrdlička fez uma revisão dos estudos até então realizados nos crânios de Lagoa Santa. Tais estudos variaram desde descrições afirmando que os crânios eram dolicocéfalos, prognáticos, robustos e semelhantes aos índios Botocudos, a publicações nas quais eram descritos como braquicéfalos e semelhantes aos índios atuais; e, ainda, como extremamente variáveis, ou seja, sem uma uniformidade morfocraniana. De acordo Hrdlička tampouco havia consenso a respeito da antiguidade e sobre a contemporaneidade entre humanos e megafauna em Lagoa Santa. Em suma, Hrdlička (1912) enquadrou a população de Lagoa Santa no homótipo americano e, portanto, semelhante aos índios atuais. Apesar de ter obtido ampla aceitação quanto à origem asiática dos nativos americanos, Hrdlička sofreu várias críticas quanto à sua definição de "homótipo americano", já que grande diversidade podia ser observada entre os povos nativos americanos (Munford et al., 1995).

Em 1938, Imbelloni analisou caracteres fenotípicos de diversos povos 
nativos do Novo Mundo e publicou a "Tabla Classificatoria" subdividindo-os em nove subtipos diferentes, colocando-se em desacordo com a homogeneidade proposta por Hrdlička. Imbelloni fez alusões as similaridades morfológicas do povo de Lagoa Santa com os melanésios em relação, principalmente, à morfologia facial. Rivet (1968) também apresentou uma alternativa para a origem dos Nativos Americanos baseado em caracteres cranianos e sugeriu que populações australianas e melanésias poderiam ter chegado à América.

O naturalista dinamarquês Peter Lund, no século XIX, por razões óbvias, foi o primeiro a analisar o material esqueletal humano de Lagoa Santa e a contribuir para as discussões sobre os primeiros americanos. Lund que afirmou o homem de Lagoa Santa apresentava características distintas das dos demais índios. Lund foi ainda mais longe ao sugerir uma idade muito antiga para a presença do homem no continente já que este teria convivido com animais pleistocênicos extintos.

Durante grande parte do século passado, a variabilidade craniana dos primeiros americanos não foi explorada pelos bioantropólogos no contexto das discussões sobre a ocupação do Novo Mundo. Essa estagnação foi devida, em muito, à idéia de Hrdlička (1907, 1912, 1932), de que todos os nativos americanos exibiriam uma mesma morfologia craniana.

Somente na década de 1970, com técnicas estatísticas mais sofisticadas, Howells (1973) ressuscitou a craniometria dando uma abordagem populacional e não tipológica aos estudos comparativos entre populações humanas. Howells apresentou seus resultados craniométricos com as populações agrupadas em dois grandes grupos: africanas - australianas e asiáticos - europeus - índios 
americanos, com polinésios ocupando posição intermediária. O silêncio nos estudos bioantropológicos sobre a origem dos nativos americanos estendeu-se até o surgimento do "Modelo das Três Migrações" (Greenberg et al., 1986). Como já mencionado, o estudo foi amplamente aceito apesar de ter recebido diversas críticas severas sobre a metodologia adotada em todos os seus pilares.

A partir dos trabalhos de Neves \& Pucciarelli (1989, 1990, 1991), lançando mãos de técnicas estatísticas multivariadas para analisar dados craniométricos, a questão da variabilidade morfológica craniana dos primeiros habitantes da América passou finalmente a ocupar posição central em tempos modernos nos debates acerca das origens do homem no Novo Mundo. Esses trabalhos mostraram que, diferentemente do esperado à luz do "Modelo das Três Migrações" (e das idéias de Hrdlička), a morfologia craniana dos primeiros americanos (paleoíndios) não pode ser associada à variação mongolóide, caso das populações ameríndias tardias e atuais.

Powell \& Steele (1992), Steele \& Powell (1992, 1993), Jantz \& Owsley (2001, 2005) e Owsley \& Jantz (2005) chegaram grosso modo a conclusões similares às de Neves \& Pucciarelli, utilizando em seus estudos os poucos crânios antigos existentes na América do Norte. Assim como no caso dos sulamericanos, a morfologia desses crânios associou-os de maneira mais consistente às populações do Sul, e não do Norte da Ásia (mongolóides clássicos). Kamminga \& Wright (1988) analisam os remanescentes esqueletais da Caverna Superior de Zhoukoudian (China) com aproximadamente 18.000, afirmando que esses indivíduos também não se assemelhavam aos asiáticos atuais de morfologia mongolóide. Em 2003, Cunningham \& Jantz, reanalizaram 
os remanescentes humanos de Zhoukoudian, concluindo que estes fariam parte de uma morfologia generalizada e não mongolóide, que seria a ancestral dos paleoamericanos.

Neves e associados lançaram-se à busca de um modelo explanatório para as associações por eles observadas. Conjugando seus achados com outras observações sobre afinidades biológicas entre fósseis do Velho Mundo, como os da Caverna Superior de Zhoukoudian, na China (Neves \& Pucciarelli, 1998), propuseram um modelo alternativo para a origem dos primeiros americanos. Batizado inicialmente de "Modelo das Quatro Migrações" (Neves e Pucciarelli, 1991; Neves et al., 1996) o modelo teve mais tarde seu nome modificado para "Modelo dos Dois Componentes Biológicos Principais" (Neves et al., 1999) (Figura 04). De acordo com esse modelo, teriam entrado duas populações biologicamente diferenciadas no continente americano, uma associada morfologicamente às populações australo-melanésicas e africanas atuias e outra associada às populações mongolóides. Desde a proposta do modelo, diversos trabalhos produzidos por Neves e colaboradores vêem corroborando seus primeiros achados e consequentemente dando suporte ao modelo proposto (Munford et al., 1995; Neves et al., 1996; Neves et al., 1999a; Neves et al., 1999b; Neves et al., 1999c; Neves et al., 1999d; Neves et al., 1999e; Powell \& Neves, 1999; Powell et al., 1999; Neves \& Blum, 1998; Blum \& Neves, 1999; Neves \& Blum, 2000; Blum et al., 2001; Neves \& Blum, 2001; Neves \& Blum, 2002; Neves et al., 2003; Hubbe et al., 2004; Neves \& Atuí, 2004; Neves et al., 2004a; Neves et al., 2004b; Neves et al., 2005; Neves \& Hubbe, 2005; Pucciarelli et al., 2006; Hubbe et al., 2007; Neves et al., 2007a; Neves et al., 
2007b; Pucciarelli et al., 2003, 2008).

Resultados obtidos por outros pesquisadores (Powell \& Steele, 1992;

Steele \& Powell, 1992, 1993; Lahr, 1995; Munford et al., 1995; Stringer, 1998; Jantz \& Owsley, 2001, 2005; Mena et al., 2003; Sardi et al., 2005; Owsley \& Jantz, 2005) e González-José et al. (2001, 2003, 2005, 2006), vêm confirmando as peculiaridades morfocranianas dos primeiros americanos defendida por Neves e associados desde o final da década de 1980 (ver Neves \& Hubbe, 2005 para uma síntese).

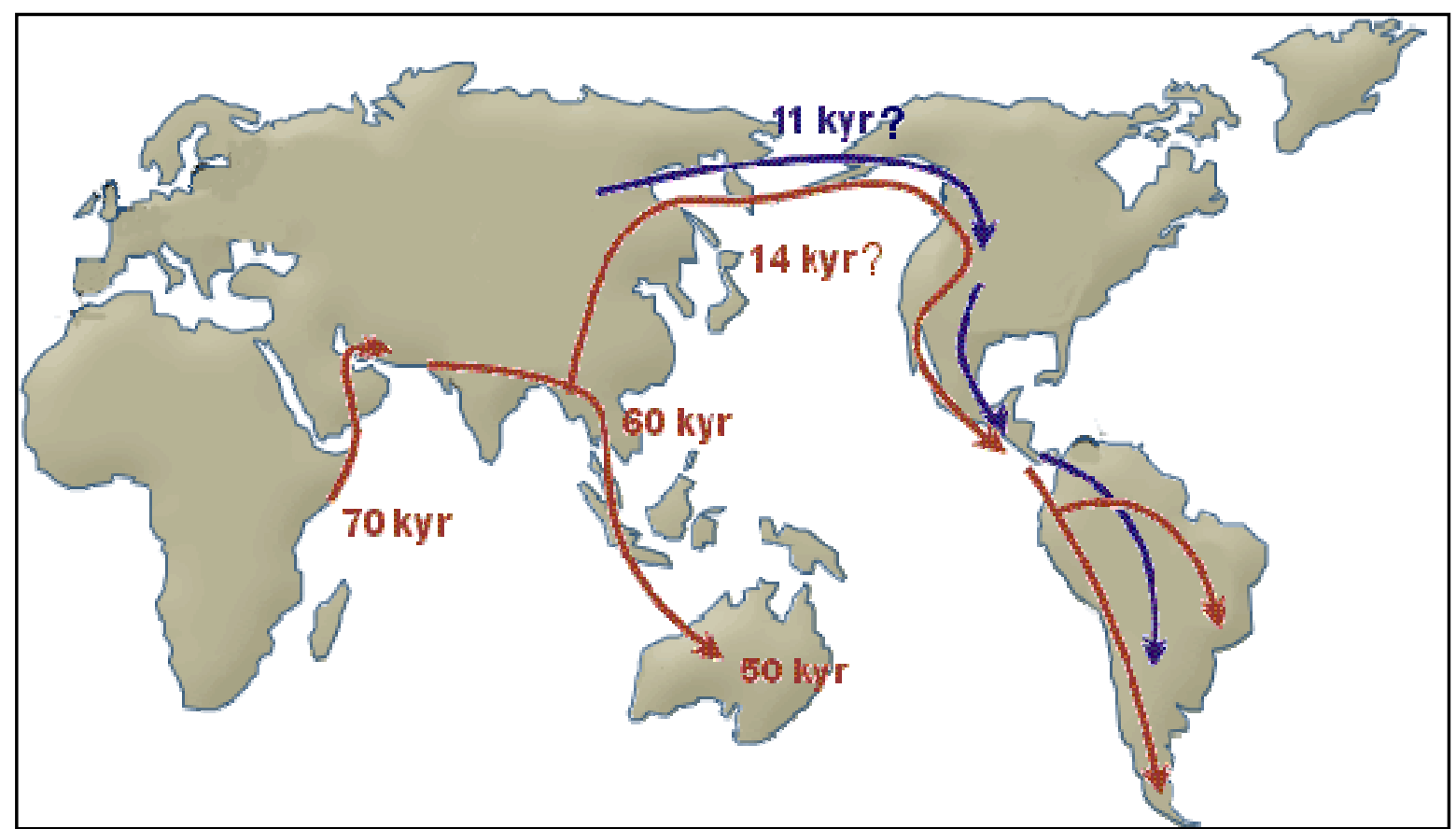

Figura 4 - Representação esquemática do "Modelo dos Dois Componentes Bioloógicos Principais". A notação kyr corresponde a milhares de anos antes do presente (A.P.) não calibrados.

O trabalho de Lahr (1995) também importante neste conxto na medida em que enfoca o processo de diferenciação das populações modernas asiáticas. Lahr (1995) diagnosticou na Ásia um padrão de descontinuidade morfológica no Pleistoceno terminal. Com uma aparição tardia no nordeste asiático do padrão mongolóide, o que apóia a possibilidade de que os primeiros americanos não 
vieram mesmo de uma população tipicamente mongolóide. Existe uma grande variabilidade no que é posto na categoria "mongolóide" (Pietrusewsky, 1992; Pietrusewsky et al., 1992; Lahr, 1995), e nenhuma das características morfológicas sozinhas podem ser consideradas como diagnóstica (Kamminga \& Wight, 1988; Lahr, 1995), apesar de algumas apresentarem alta freqüência em alguns grupos.

As análises craniométricas realizadas especificamente no continente americano por Lahr (1995) demonstraram uma afinidade de forma entre as populações Fueguinas e Patagonicas e as populações do Pacífico Sul bem como certa distância das demais populações nativas americanas. No que diz respeito à robustez, as populações Fueguinas e Patagônicas, são comparáveis somente às populações australianas. Supondo a existência de uma especialização para regiões frias, quando comparados aos Esquimós, os caracteres altamente correlacionados entre as populações indicam uma tendência similar de pressão biomecânica e não climática, já que as variáveis métricas nasais (primordiais para a adaptação ao frio) estão presentes nos esquimós, mas ausentes nos fueguinos e patagões. Apesar de poucos dentes terem sido analisados, os que 0 foram apresentam dentição sundadôntica. Portanto, as populações fueguinas e patagônias analisadas por Lahr (1995) seriam derivadas de uma população mongolóide menos especializada, anterior à diferenciação da morfologia típica Mongolóide-Sinodonte.

Mena et al. (2003) ao estudarem remanescentes ósseos arcaicos chilenos, proposeram que os indivíduos analisados, apesar de classificados como mongolóides, não exibem os caracteres clássicos dessa morfologia, e que 
poderiam fazer parte de um estoque andiano generalizado não-mongolóide. Neste sentido, Pucciarelli et al. $(2006,2008)$ diagnosticaram a descontinuidade de variação nativa americana no sentido leste-oeste, tendo a Cordilheira dos Andes como barreira natural (como, aliás, havia já sugerido Dixon, 2001). Isto explicaria a dispersão dos primeiros americanos no continente, constituindo dois universos microevolutivos distintos e independentes.

Já Brace et al. (2001), ao estudarem caracteres craniofaciais, concluiu que os primeiros americanos assemelhavam-se com aos Ainu de Hokkaido, ao passo que os Aleutas e Na-denes estariam mais próximos das populações do leste asiático (ver Figura 5).

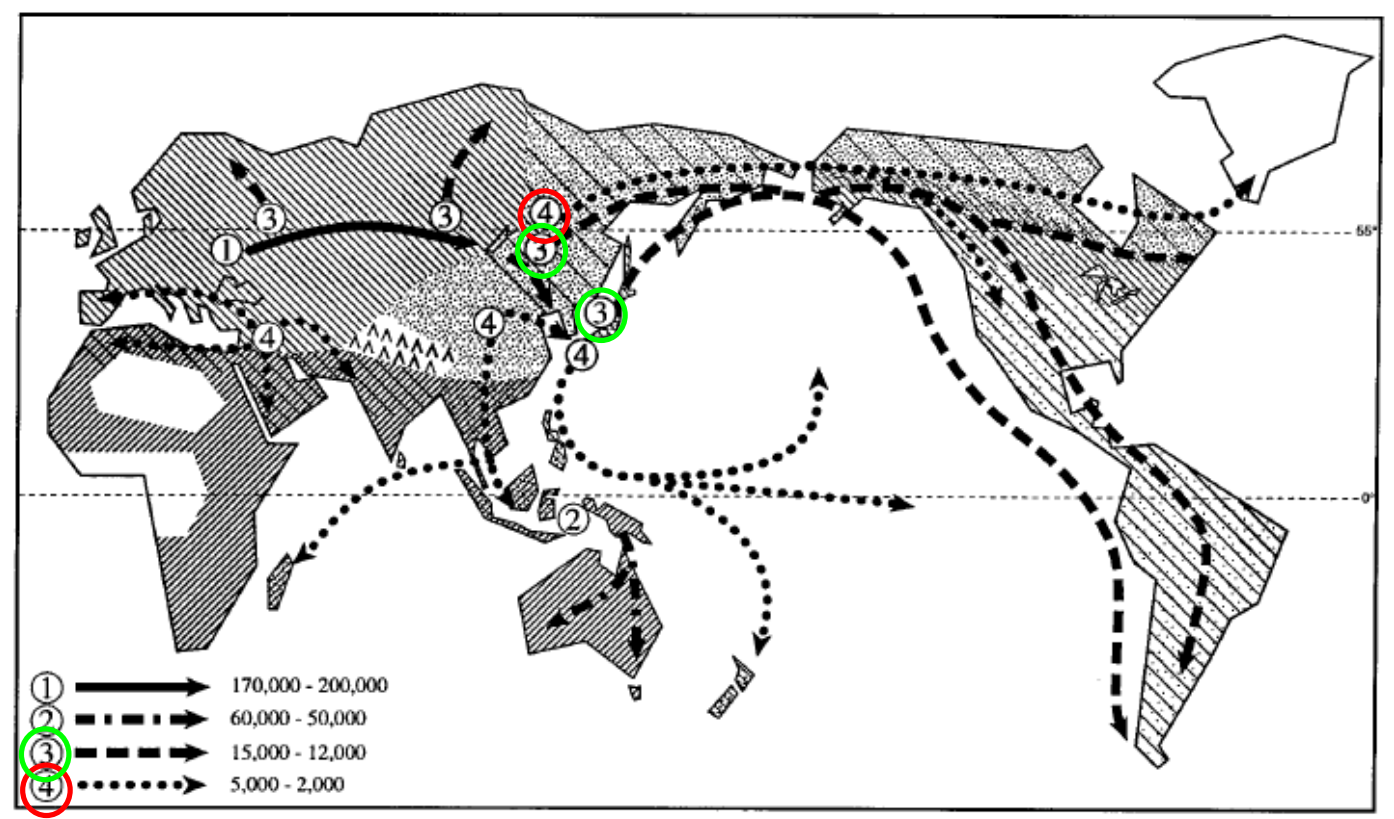

Figura 5 - Povoamento da América de acordo com Brace et al. (2001), de onde a figura foi extraída.

Munford et al. (1995) sugeriu que a substituição da morfologia mais generalizada encontrada nos paleoíndios para a morfologia mais especializada, mongolóide, teria ocorrido na América do Sul de forma abrupta, já que não existem morfologias intermediárias entre esses dois padrões craniométricos 
durante o Holoceno Médio. O modelo proposto por Neves e colaboradores ("Modelo dos Dois Componentes Principais") assumiu inicialmente que em algum momento houve um processo de substituição que extinguiu a morfologia mais generalizada na América do Sul.

No entanto, trabalhos de diferentes autores vêem sugerindo que existem populações remanescentes com morfologia generalizada. Este é o caso dos fueguinos (Lahr, 1995), povos andinos patagões (Mena et al., 2003), e dos Pericus da Baja Califórnia (Gonzalez-José et al., 2003), o que apóia a suposição do "Modelo dos Dois Componentes Principais" de que se a morfologia generalizada tivesse sobrevivido isso teria acontecido em regiões periféricas e/ou isoladas (Neves et al., 1999). Naturalmente, o modelo de Neves e colaboradores recebeu diversas críticas da comunidade científica norteamericana.

Recentemente um trabalho publicado por González-Jose et al. (2008) propõe um novo cenário para o povoamento do continente. Os autores sugerem que os padrões morfológicos generalizado e mongolóide constituem apenas extremos de um espectro de variação morfológica e não padrões distintos e independentes. O modelo proposto leva em consideração dados arqueológicos, genéticos e craniométricos está de acordo com o "Modelo Out of Beringia" ou "Modelo de Migração Única", afirmando que teria ocorrido um evento único de migração de uma população extremamente variada para o povoamento da América. 


\subsubsection{Os Estudos Odontológicos}

\subsubsection{A odontologia dos primeiros americanos}

Além das relações inter-populacionais observáveis através das afinidades morfocranianas, o estudo da morfologia dentária também vem contribuindo para as discussões sobre as origens dos primeiros americanos. Durante as últimas décadas, muitos antropólogos têm focado suas análises dentárias em características não-métricas da coroa e da raiz para definirem os padrões dentários dos grandes grupos geográficos (e.g. Greenberg, et al., 1986; Hanihara, 1996, 2005; Irish \& Guatelli-Steinberg, 2003). A variação odontométrica também tem sido utilizada para a investigação da evolução hominínea de maneira mais ampla e da diversidade local e regional de grupos humanos recentes (Brace, 1980; Scott \& Lockwood, 2004; Bermudez de Castro et al., 2004). O estudo da morfologia externa dos dentes por métodos não destrutivos e relativamente baratos tem sido feito devido à natureza estrutural dentária, que constitui um dos vestígios arqueológicos e paleontológicas mais abundantes e, conseqüentemente, um dos mais estudados na paleoantropologia (Bailey, 2007; Macchiarelli \& Bailey, 2007).

As protuberâncias e ranhuras que estão na superfície dentária são mais desafiadoras para quantificar relações evolutivas do que as variáveis métricas, mais simples (Bailey, 2007). Dentre as possibilidades exploradas com o intuito de quantificar a variação dentária estão o estudo das áreas relativas das cúspides (Wood \& Abbott, 1983; Wood \& Uytterschaut, 1987; Wood \& Engelman, 1988; Bailey et al., 2004; Moggi-Cecchi \& Boccone, 2007), os 
ângulos das cúspides (Morris, 1986; Bailey et al., 2004), altura dos gumes (Pilbrow, 2003, 2007), assim como caracteres não métricos ou discretos (Hrdlička, 1932; Dahlberg, 1945; Turner \& Scott, 1977; Turner, 1985; Sofaer et al., 1972; Turner, 1990; Turner et al., 1991; Turner, 1992; Irish, 1994; Hanihara, 1996; Turner II \& Hawkey, 1998; Bailey, 2002; Irish \& GuatelliSteinberg, 2003). Mas é claro que o material analisado precisa estar em ótimo estado de conservação para que tais caracteres sejam analisados, além de terem sofrido pouco ou nenhum desgaste, condições extremamente raras em material arqueológico de considerável profundidade temporal como neste estudo.

Análises fenéticas, ao invés das filogenéticas, são mais comumente 0 foco de estudos de morfologia dentária. Inicialmente estimadas pelo cálculo da Medida de Divergência Média (do inglês, Mean Measure of Divergence) (Sjøvold, 1973; Berry, 1976; Harris \& Sjøvold, 2004; Bailey \& Wood, 2004), pelas distancias biológicas, como a distância de Mahalanobis; deveriam ser subistituídas, de acordo com o proposto por Manni et al. (2007), pela aplicação do estudo das redes neurais artificiais pelo método de Mapas de AutoOrganização (do inglês, Self Organizing Maps - SOMs). As vantagens das técnicas supracitadas são primeiramente o uso de espécimes com valores ausentes, com um tratamento diferenciado dos valores ausentes já que não é necessário a substituição através de estimações de valores - muito comuns em materiais arqueológicos - e o foco da análise nos indivíduos ao invés das freqüências dos caracteres nas amostras. 
Estudos focando a anatomia dentária de populações humanas modernas têm mostrado, em escala global, o potencial considerável dos caracteres dentários como ferramentas para entender a relação fenética entre populações (e.g. Scott \& Turner, 1997). Tendo em vista este potencial, vários autores vêm estudando variação dentáris aplicada à emergência dos humanos anatomicamente modernos (e.g., Stringer et al., 1997; Irish 1997, 1998; Bailey \& Turner, 1999; Bailey 2002, 2004; Irish \& Guattelli-Steinberg, 2002; Bailey \& Lynch, 2005; Manni, et al. 2007).

K. Hanihara, em 1967, identificou dois tipos principais de caracteres morfológicos nas coroas dentárias das diferentes raças. Dos dois tipos de caracteres identificados por K. Hanihara, um tipo refere-se a diferenças nas frequências e o outro à similaridades nas freqüências, ou como Dahlberg chamou, em 1945, de "característica invariável intra-racial" e "característica variável inter-racial". Baseado nestes dois tipos de características, Hanihara (1967) propôs a definição do "Complexo Dentário Mongolóide", iniciando uma tendência classificatória que seria seguida por muitos pesquisadores para a definição de afinidades biológicas que ajudariam a contar a história do homem moderno.

Stringer et al. (1997) atacaram a questão da origem única ou multiregional dos humanos anatomicamente modernos através da análise da morfologia dentária de acordo com o protocolo ASUDAS. Quando a África foi tratada como um único grupo populacional, emergiu como grupo externo em relação às demais populações humanas. Quando a amostra africana foi subdividida em dois grupos, Norte da África e África Subsaariana, a África 
Subsaariana divergiu primeiro, seguida pela Austrália, Melanésia, e pelo grupo formado pela Europa e Norte da África. Entre as populações asiáticas, as populações mais antigas do sudeste asiático foram as primeiras a divergir, seguidas das populações recentes da mesma região, incluindo a Sibéria. A árvore mais parcimoniosa das duas análises sugeriu uma divergência antiga para as populações da África e da Australo-Melanésia. Os Africanos subsaarianos apresentaram grande heterogeneidade intra-regional, o que poderia significar grande profundidade temporal; eles sempre se apresentam distintos dos demais grupos amostrados (Irish \& Guatelli-Steinberg, 2003, Figura 06). Os resultados, de acordo com Irish (1994, 1997, 1998), apoiariam o "Modelo da Monogênese Africana". Este mesmo padrão foi confirmado em estudos posteriores (Irish \& Guatelliu-Steinberg, 2003; Hanihara 1996; Hanihara \& Ishida, 2005; Hanihara, 2008).

Hanihara (2008) constatou um gradiente de variação não-métrica partindo da África Subsaariana para zonas mais periféricas (Figura 07). A relação entre variação regional e distância geográfica sustenta a idéia de diversos episódios de gargalo populacional durante a expansão da África para o resto do mundo. A variação do leste e do nordeste asiático é relativamente alta, sugerindo uma história populacional complexa como migrações múltiplas a partir de fontes externas. 


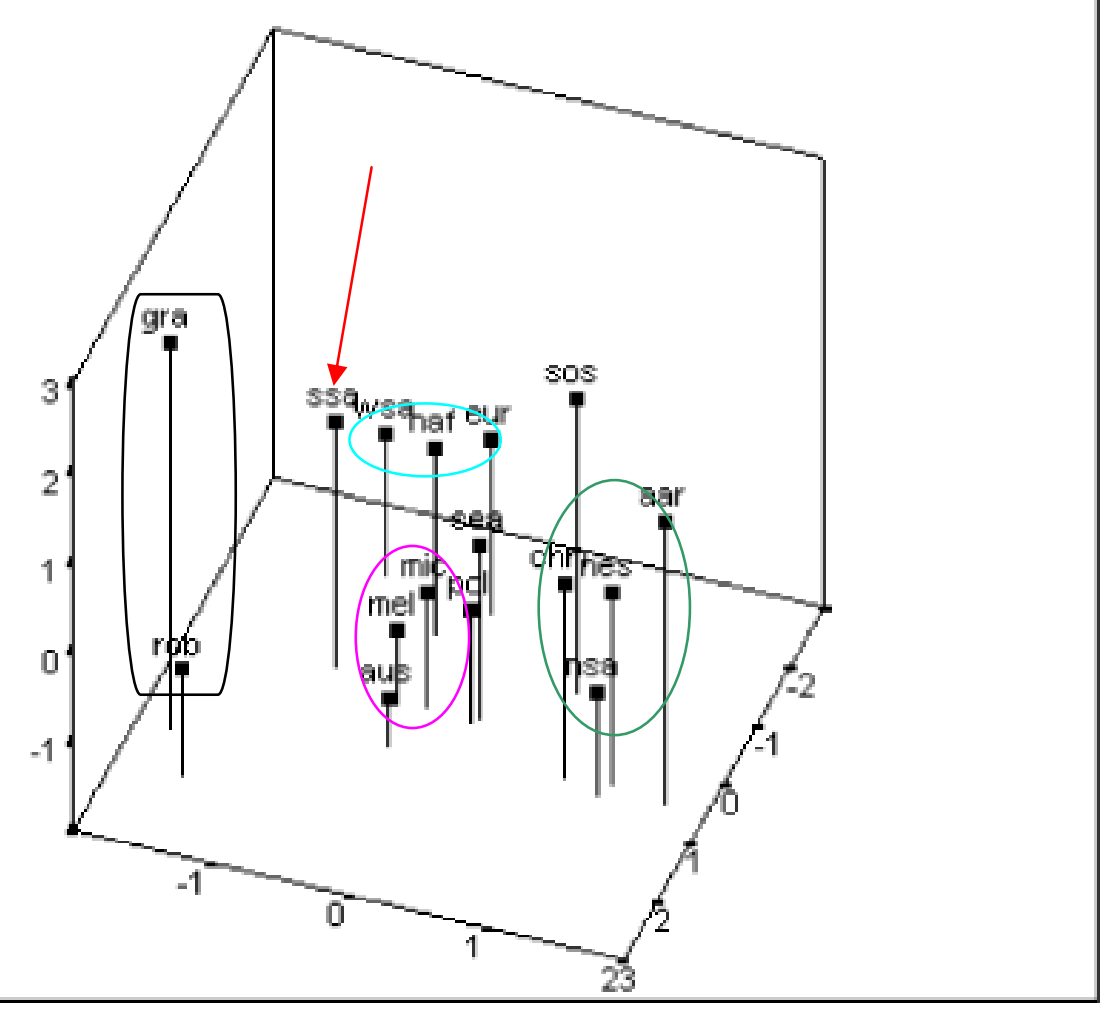

Figura 6 - Gráfico de dispersão ao longo dos três primeiros componentes principais, extraído de Irish \& Guatelli-Steinberg (2003), com a seta vermelha destacando a população africana subsaariana; círculo verde destacando os mongolóides; círculo rosa as populações da Oceania; círculo azul as européias; e retângulo preto os australopitecineos robustos e gráceis utilizados como grupos externos.

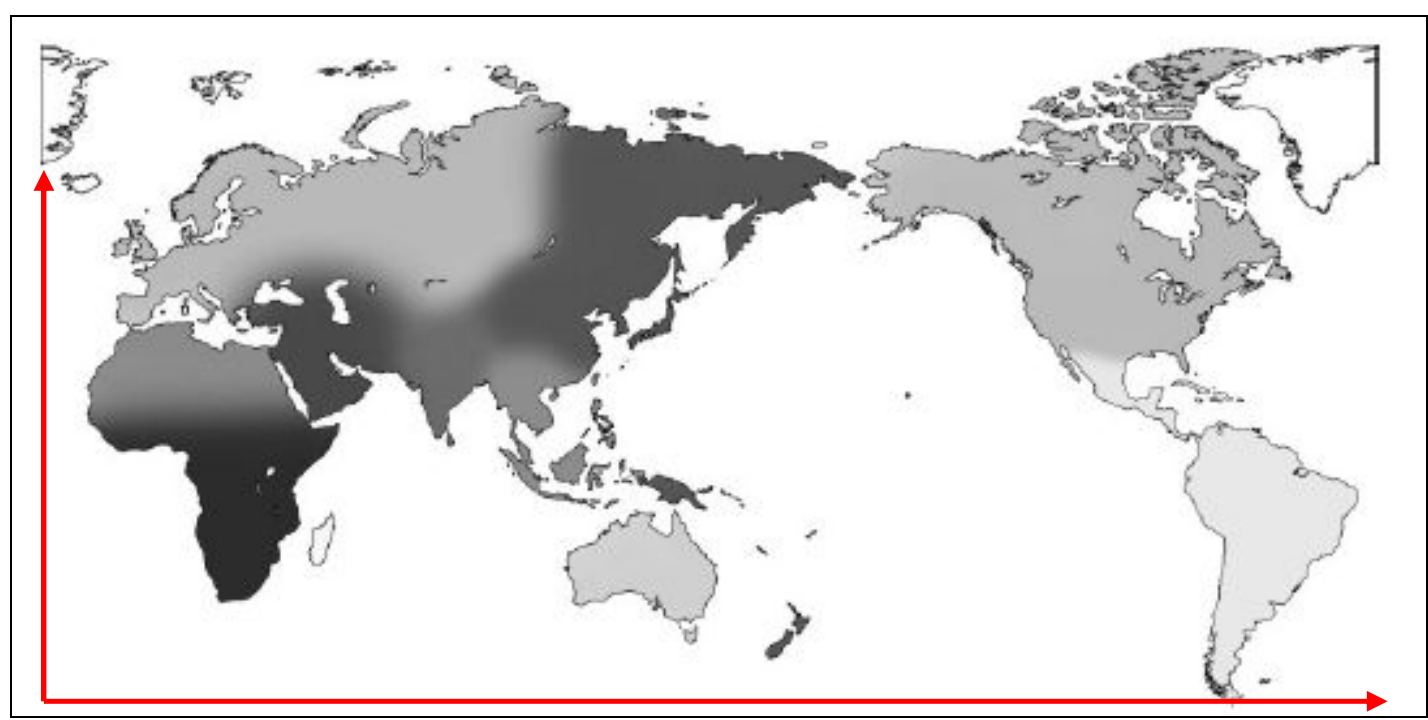

Figura 7 - Mapa mundial apresentando o degradê de variabilidade intra-populacional extraído de Hanihara (2008). Setas em vermelho indicam o sentido do gradiente proposto pelo autor.

Confirmando as afirmações de Turner II (1981, 1985, 1987, 1990 e 1992), Hanihara (2008) sugeriu que os resultados por ele obtidos indicam que 
os caracteres não métricos dentários não foram submetidos a grandes pressões seletivas durante o passado recente e que as variações regionais, de maneira geral, estão de acordo com as expectativas oriundas da biologia molecular.

Com um trabalho de âmbito mundial com populações atuais, K. Hanihara (1976) obteve resultados que indicam que os aborígines australianos excedem todas as demais populações quanto ao diâmetro mesiodistal da coroa dentária de modo geral. No entanto, surpreendentemente, os Pimas têm os dentes anteriores maiores, sobretudo os caninos superiores. Os negros americanos também possuem dentes com grande diâmetro, ligeiramente menores que 0 dos australianos, porém com robustez semelhante. Abordando a questão das afinidades entre as populações em si, K. Hanihara (1976) observou que as amostras masculinas se agrupavam em: 1) Aleutas e ainus; 2) Pimas, japoneses, javaneses, lapões; 3) Negros americanos e aborígenes australianos; e 4) Suíços, caucasianos, tristaneses e brancos americanos. E as amostras femininas da seguinte forma: 1) Aborígenes australianos, negros americanos, tristaneses, suíços, caucasóides e brancos americanos; 2) Pimas, javaneses, japoneses e ainus; e 4) Aleutas.

Penrose (1954) já havia enfatizado que o "componente forma" talvez fosse mais importante que o "componente tamanho" nas comparações entre populações e os resultados apresentados por Hanihara (1977) parecem ter confirmado tal importância. Ao calcular a distância de Penrose, que leva em consideração tanto a forma quanto o tamanho, mas separadamente (o que a distancia de Mahalanobis não faz), o autor obteve os resultados que podem ser visualizados na Figura 8. 


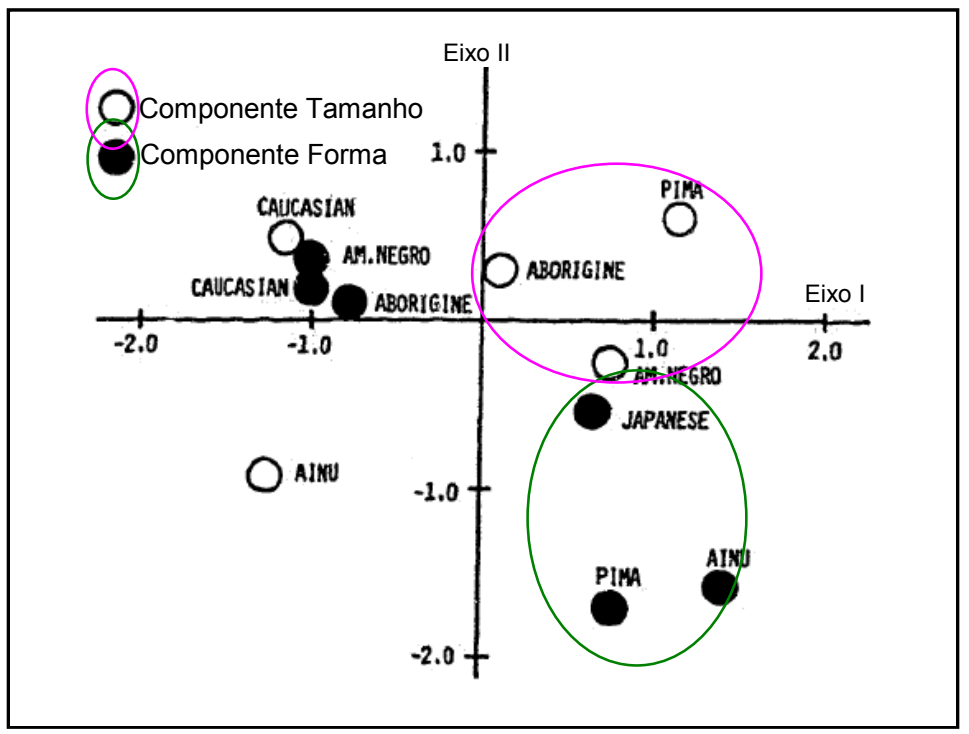

Figura 8 - Representação gráfica do componente tamanho (destacado em rosa) e forma (destacado em verde) extraída de Hanihara (1977).

Considerando o "componente forma" como sendo o melhor estimador da divergência entre populações, pode-se observar uma grande diferença entre os australianos, negros americanos e caucasóides em oposição aos japoneses, pimas e ainus. O que parece fazer mais sentido geográfico do que a distribuição baseada no tamanho dentário que aproxima os aborígines australianos, pimas e negros americanos, observado na parte superior direita da Figura 5.

Dos 28 traços não-métricos por ele analisados, Turner II (1990) propôs a divisão em sundadontes e sinodontes para o "Complexo Dentário Mongolóide Asiático" (confirmado em estudos posteriores, como por exemplo Brace \& Hunt, 1990; Hanihara, 1996; Irish \& Guatelli-Steinberg, 2003). O padrão sundadonte apresenta uma série de características que foram abundates durante 0 pleistoceno tardio e atualmente encontra-se restrito ao sudeste asiático. 0 padrão sinodonte é mais especializado e é encontrado no norte asiático até os dias atuais. Os chineses, japoneses, mongóis, siberianos do extremo leste e todos as populações nativas americanas apresentam o padrão sinodonte. Os 
sinodontes teriam supostamente surgido no final do Pleistoceno como registrado nos crânios da Caverna Superior de Zhoukordian, no norte da China.

Para explicar essa distinção entre sinodontes e sundadontes, Turner II (1990) propôs uma evolução local do padrão sundadôntico. Para explicar a origem dos dois padrões, Turner II reafirmou o proposto por Hanihara (1977), defendendo assim que o padrão sundadôntico existiu no sudeste asiático até pelo menos há 12.000 A.P., o que foi antes da migração mongolóide para o sul. Consequentemente, o padrão sundadôntico não poderia ter se originado através da mistura de mongolóides e australo-melanésios, como alguns pesquisadores sustentavam (para um exemplo ver Von Koenisgswald, 1952).

Em um trabalho posterior, Turner II (1992) foi mais preciso em relação à distinção do padrão sinodonte, afirmando que o padrão sundadonte é o grupo externo do qual mais facilmente teriam evoluido os padrões dentários mais recentes, por deriva e seleção. Tanto o padrão europeu quanto o sinodonte asiático (teriam sofrido o mesmo tipo de pressão seletiva já que evoluíram sob padrões de processamento alimentar e em ambientes árticos e sub-árticos semelhantes) teriam tido suas origens diretamente dos sundadontes.

Matsumura \& Hudson (2005), a partir da análise métrica e não métrica de dentes permanentes do sudeste da Ásia, sugeriram que houve uma primeira leva migratória à região do sudeste asiático que posteriormente misturou-se com imigrantes mongolóides do leste asiático durante a expansão agrícola do neolítico. As características dentárias da maioria dos atuais habitantes do sudeste asiático revelam uma clara mistura de caracteres associados às populações do leste asiático e dos Australo-Melanésios. 
Conforme já mensionado, Turner II utilizou o termo sundadonte para caracterizar a morfologia dentária das populações recentes do sudeste asiático. Matsumura \& Hudson (2005) propuseram que o termo sundadonte fosse utilizado apenas para populações australo-melanésias e pré-neoliticas do sudeste asiático, já que as populações atuais da região não compartilham do padrão sundadôntico, devido a influências vindas do norte.

Comparações dentárias realizadas por Turner II (1981) entre asiáticos e nativos americanos, tanto de períodos tardios quanto recentes, monstraram grandes similaridades, sugerindo a ocorrência de reduzida microevolução na América, nos últimos 11.000 anos. Para ele, todos os índios americanos possuem dentes que se parecem muito mais com asiáticos do que com europeus.

Em 1986, essas afirmações sobre a suposta homogeneidade americana foram consolidadas no trabalho de Greenberg et al. (1986), que sugere que o povoamento da América se deu em três migrações distintas no final do Pleistoceno a partir da Sibéria, todas com caracteres sinodontes. Turner II (coautor do artigo de Greenberg et al., 1986) demonstrou que existe maior variabilidade dentária no norte do que no sul do continente americano, e portanto a existência de um evidente sentido norte-sul para o povoamento da América a partir do Alasca.

A variação dentária no Novo Mundo apresenta, segundo Greenberg et al. (1986), três clusters distintos: 1) todos os índios norte e sul-americanos ou Macro Índios, provenientes das estepes e tundras siberianas; 2) Grande Costa Nordeste ou Na-Dene, originados das florestas siberianas; e 3) Aleutas - 
Esquimós, com origem na região costeira da Sibéria, com todos os padrões dentários (sinodontia) evoluídos na Ásia. Greenberg et al. (1986) chegaram a afirmar que "... é possível que tenha existido um grupo pré-Clovis que tenha entrado no Novo Mundo e que não tenha deixado nenhum descendente entre os índios atuais, mas esse não é um caminho parcimonioso para explicar a relação entre tempo-dente-Clovis" (pg. 484). Os autores do Modelo das Três Migrações mostraram-se absolutamente pessimistas quanto à possibilidade de uma migração pré-Clovis, mas não a descartaram perimptoriamente.

Powell (1993) se propôs a revisar as análises realizadas por Turner II (1985, 1992) e por Greenberg et al. (1986) apontando problemas nas suposições de suas análises estatísticas, principalmente no que se refere ao uso de Análises de Cluster do tipo "unweighted pair group" (UPGMA) para traços discretos. Segundo Powell, análises UPGMA geram frequentemente clusters suspeitos e podem não serem válidos para resgatar relações evolutivas porque assumem que as taxas de mudanças envolvidas são iguais para todas as populações. Powell (1993) usou técnicas analíticas alternativas, que teriam vantagens sobre as utilizadas por Turner II, por não assumirem taxas iguais de mudança evolutiva para diferentes populações, eliminado, conseqüentemente, a possibilidade de juntar em um mesmo cluster populações que apenas evoluem com taxas semelhantes e que na verdade não apresentam afinidades biológicas ou, em outras palavras, que não dividem uma história evolutiva recente. Apesar das críticas, os resultados obtidos por Powell produziram dendrogramas similares aos apresentados por Turner II e associados. No entanto, algumas considerações poderam ser efeituadas por Powell (1993). Os 
paleoíndios apesar de se agruparem com as demais populações nativas do Novo Mundo, guardam com elas uma certa distância, sugerindo uma posição única em relação às outras séries americanas, em todas as análises realizadas (Figura 9).

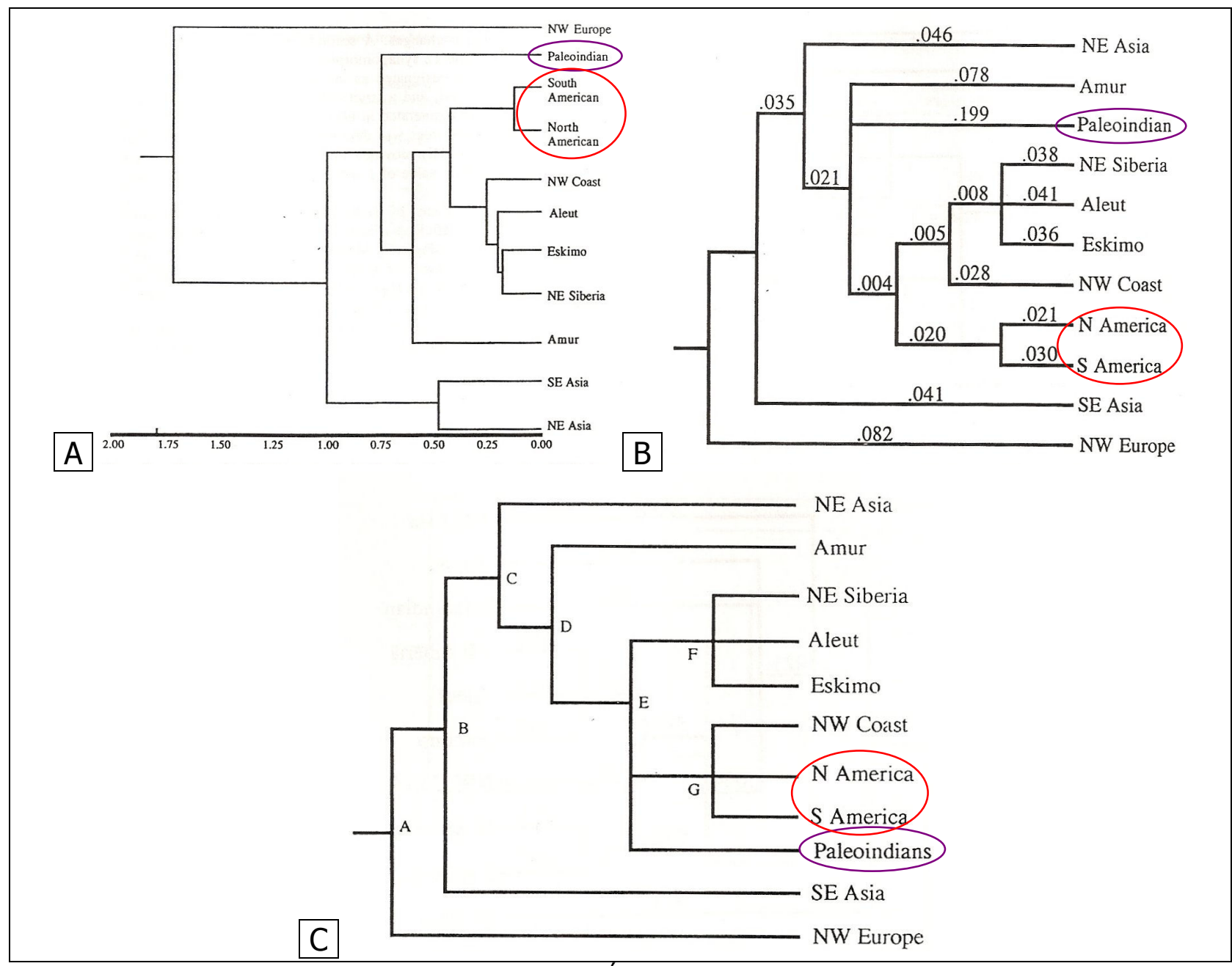

Figura 9 - Dendrogramas extraídos de Powell (1993). A) Árvore produzida pelo agrupamento de UPGMA baseada nos dados de MMD para 28 traços morfológicos; B) Árvore produzida sob a distância de Wagner do 28 traços morfodentários usando a optimização de Fitch-Margoliash; e C) Árvore produzida pelo consenso da Máxima Parcimônia utilizando 12 segmentos codificadores sinapomorficos de traços morfodentários. Em destaque (círculos) a posição dos Paleoíndios em roxo e em vermelho os demais nativos americanos.

Powell (1993) destacou ainda que alguns problemas e vieses podem ser observados nesses grupos em especial. É possível que a inclusão de indivíduos provenientes do Holoceno inicial na amostra paleoíndia tenha diminuído a distância entre os primeiros americanos. Outro ponto que deve ser questionado 
é o tamanho americano representados na análise reduzido da amostra paleoíndia, o que pode facilmente ter afetado os resultados.

Powell (1993) também atacou a subdivisão dos asiáticos em sinodontes e sundadontes dizendo que "...apesar dos complexos sinodonte e sundadonte serem bastante reais, o estado dos carateres é muito mais complicado que o descrito por Turner II" (pg. 815). Em outras palavras, alguns traços parecem ser muito mais característicos de determinados agrupamentos resultados dos artifícios estatísticos do que realmente das populações.

A homogeneidade fenotípica dentária americana também não foi apoiado pelos trabalhos de Powell (1993, 1995 e 1997), tanto para dados métricos quanto para não métricos. Análises discriminantes e distâncias biológicas não revelaram uma clara divisão em três ondas populacionais para o Novo Mundo. Quando a classificação dos dentes por caracteres não métricos do protocolo ASUDAS proposto por Turner II foi utilizada para espécimes norte-americanos do Holoceno Médio re-analisados por Powell (1995), os paleoamericanos foram classificados como sundadontes e não como sinodontes. Resultado que vai em direção oposta ao esperado pelo Modelo Tripartite.

Powell (1997), analisando amostras esqueletais adicionais de Paleoíndios, datados entre 8.500 e 10.700 A.P. e do Holoceno Médio (8.500-5.000) A.P. pôde observar que em termos dentários os Paleoíndios não se monstram afins a nenhuma população moderna tendo se comportado como outliers. De acordo com Powell (1997) uma considerável variabilidade pode ser identificada logo após a entrada dos primeiros migrantes no continente, seguida por uma redução da variabilidade e uma tendência à homogenização nos descentes dos 
Paleoíndios, que podem ser atribuídas a processos microevolutivos locais como o efeito fundador, deriva genética, entre outros - (Powell, 1997).

Somente recentemente foi publicado um estudo de âmbito mundial, com um bando de dados com mais de 7.000 indivíduos do sexo masculino, baseado em caracteres métricos dentários (Hanihara \& Ishida, 2005) que confirmou concomitantemente várias das relações entre populações humanas já conhecidas da literatura (Figura 10).
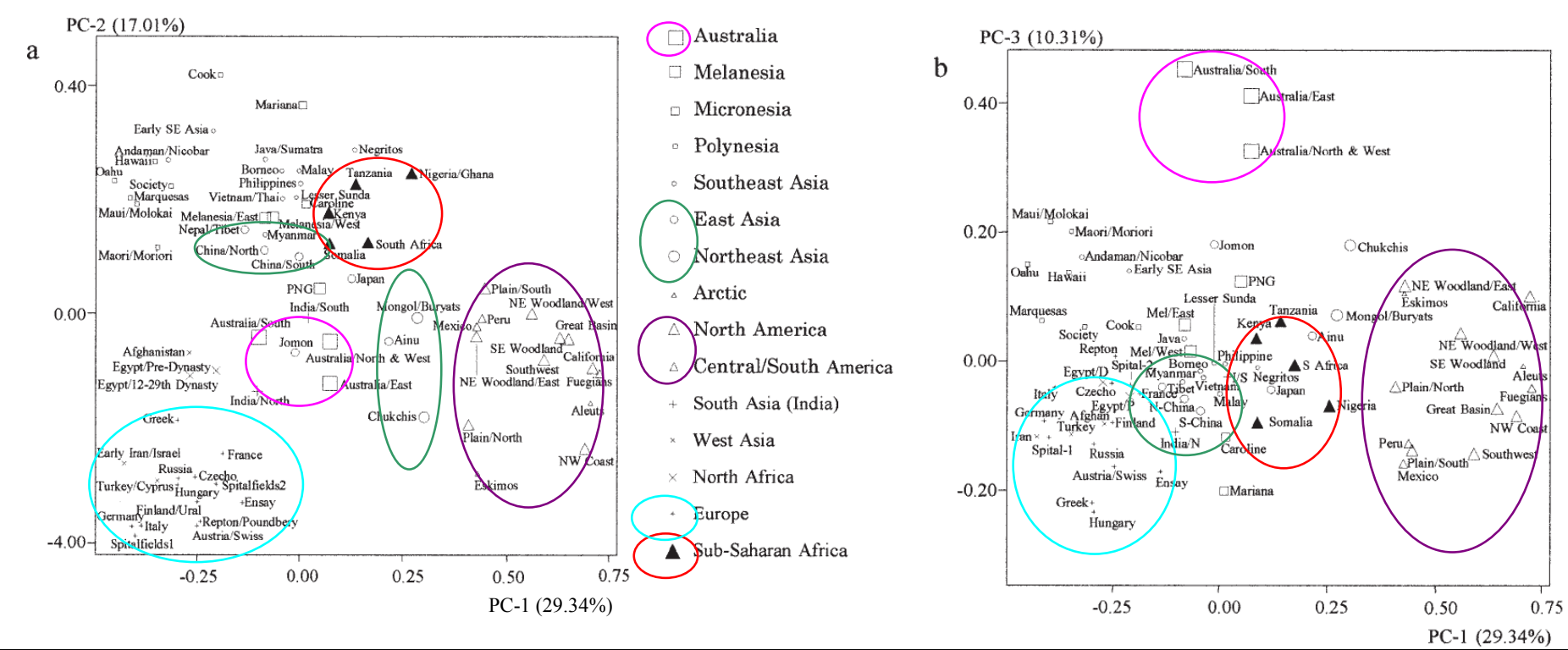

Figura 10 - Afinidades Biológicas entre as populações mundiais com base em Análise de Componentes Principais (dados corrigidos por CScore), extraído de Hanihara \& Ishida (2005). Destaque para os círculos inseridos na figura: roxo para o Continente Americano, vermelho para a África Sub-saariana, verde para o Leste e o Norte asiáticos, e azul para Europa.

Os principais resultados obtidos por Hanihara \& Ishida (2005) foram: 1) os australianos possuem os maiores dentes, seguidos pelos melanésios, micronésios, africanos subsaarianos e nativos americanos; 2) Negritos filipinos, Jomon/Ainu e euro-asiáticos orientais possuem dentes pequenos; 3) Leste e Sudeste Asiáticos, bem como Polinésios são intermediários quanto ao tamanho; 4) em termos de forma somente, os extremos mundiais são representados 
pelos europeus, pelos nativos americanos e pelos australianos; 5) Leste e Sudeste Asiáticos apresentam caracteres similares com africanos subsaarianos, agrupando-se, ambos no centro do espaço fenético; 6) o padrão de variação das grandes populações geográficas é relativamente consistente com os obtidos por dados craniométricos e genéticos.

\subsubsection{A base genética-evolutiva dos dentes humanos}

Avanços recentes na Antropologia Biológica, na Biologia do Desenvolvimento, na Genética Quantitativa e na Anatomia Microestrurural ilustram a extraordinária quantidade de informação presente e/ou possível de ser retirada através do estudo dos dentes (e.g., Harris \& McKee, 1990; Jernevall \& Jung, 2000; Jung et al., 2003; Irish \& Guatelli-Steinberg, 2003; Hlusko, 2004; Harris \& Sjøvold, 2004; Bailey et al., 2004; Hanihara \& Ishida, 2005; Olejniczak et al., 2007; Manni et al., 2007; Macchiarelli \& Bailey, 2007; Wood, 2007; Braga \& Heuze; 2007; Macchiarelli \& Bailey, 2007).

Uma suposição básica na Bioantropologia é que o desenvolvimento dentário é menos influenciado por fatores ambientais imediatos do que o resto do esqueleto, sendo, conseqüentemente, um melhor indicador de afinidades genéticas (Cardoso, 2007). Demirjian et al. (1985) analisaram a inter-relação entre somático, dentário, esqueletal e maturação sexual em crianças e jovens norte-americanos e descobriram que a formação dentária é uma das características mais geneticamente estáveis nos humanos. Trabalhos 
relacionando fatores ambientais, como atrasos na maturação, estresse, doenças e variações no estatus sócio-econômico, também vem confirmando que o desenvolvimento dentário é menos sensível a esses fatores (Kieser, 1990; Larsen, 1997; Cardoso 2007; Stojanowski et al., 2007).

Como qualquer outra estrutura biológica, as características dentárias refletem não somente demandas funcionais e adaptações no contexto da filogenia, mas também o processo de desenvolvimento controlado pela morfogênese. A morfogênese é mais estável nos dentes que em outros elementos ósseos, porque depois da erupção o formato da coroa só é alterado por desgaste, e não por remodelamento ósseo (Jernevall \& Jung, 2000). As análises odontométricas podem incluir indivíduos adultos e jovens, devido ao fato de que as coroas dentárias permanentes são totalmente formadas antes de sua erupção, ou seja, em fases iniciais do desenvolvimento (Hilson, 1996).

Entretanto, a suposição de que os dentes seguem uma trajetória alométrica simples em relação ao tamanho corporal não foi até agora confirmada por completo. Alguns estudos afirmam existirem relações sistemáticas, positivas e de baixa ordem entre tamanho dentário e variação de diversas partes do corpo humano (Garn et al., 1968a, b e c). No entanto, para alguns autores, essas relações são demasiadamente baixas, apesar de estatisticamente significativas (Henderson et al., 1976). Indívíduos maiores de fato possuem dentes maiores em sentido absoluto, mas não relativo, ou seja, indivíduos mais altos não possuem dentes maiores em comparação com os indivíduos mais baixos (Kurtén, 1967; Perzigizn, 1976) e alguns trabalhos até mesmo já indentificaram relações negativas entre tamanho dentário e corporal 
(Kieser \& Groeneveld, 1988). E ainda, Harris et al. (1983) ao analisarem o tamanho corporal através de medidas craniométricas (comprimento da base craniana e distância nasion-basion) e compará-las com o diâmetro mesiodistal dos dentes, encontraram uma independência entre essas medidas nas populações humanas. Conseqüentemente, existem diferenças significativas nas relações de tamanho e forma entre humanos (Cheverud, 1982).

As estimativas de herdabilidade são geralmente altas para todas as grandes medidas da coroa dentária, variando de 60 a 82\% (Townsend et al., 2003), contrastando com a baixa e altamente variável herdabilidade observada nas medidas intercúspides, indicando claramente a influência de fatores ambientais imediatos sobre estas últimas (Dempsey \& Townsend, 2001; Hanihara \& Ishida, 2005). Lewis \& Grainger (1967) ao estudarem 43 famílias sugeriram que o tamanho de ambos os diâmetros dentários são ao menos parcialmente regido por herança genética ligada ao sexo, mais precisamente pelo cromossomo X (resultado que já havia sido observado por Garn et al., 1965 para os diâmetros mesiodistais). Alvesalo \& Tigerstedt (1974) analisaram a influência genética nas diferentes dimensões dos dentes humanos e encontraram um amplo espectro de variação de herdabilidade. A herdabilidade foi geralmente menor nos dentes distais dos grupos dentários, à exceção dos incisivos laterais inferiores (confirmado posteriormente por Hanihara, 1976 e identificado anteriormente por Moorrees \& Reed, 1964). Alvesalo \& Tigerstedt (1974) sugeriram que os dentes distais dos grupos dentários estão mais submetidos a pressões seletivas.

As diferenças comumente encontradas no tamanho dentário entre 
homens e mulheres devem-se a diferenças no tamanho do corpo no geral e ocorrem em todas as populações humanas (Brace \& Ryan, 1980; Brace \& Nagai, 1982). Estas diferenças seriam decorrentes e/ou resíduos do dimorfismo sexual que foi mantido por razões adaptativas a partir do Pleistoceno Médio. Segundo Brace (1967); Brace \& Mahler (1971); Brace \& Ryan (1980); Brace \& Nagai, (1982); Brace et al. (1984) e Brace et al. (1987) o desenvolvimento de técnicas de processamento de alimentos no final do Pleistoceno teria levado à redução, em ambos os sexos, das dimensões dentárias. Brace \& Ryan (1980) sugeriram que o dimorfismo sexual teria sido mantido até o final do Pleistoceno, quando a caça de grandes animais por técnicas rudimentares foi substituída pela caça de pequenos animais, com mecanismos mais sofisticados e pelo aumento do consumo de alimentos de origem vegetal. A redução subseqüente no dimorfismo seria conseqüência do "Probable Mutation Effect" (PME, sigla em inglês) operando sob condições de relaxamento da seleção (Brace, 1967; Brace \& Mahler, 1971; Brace \& Ryan, 1980; Brace \& Nagai, 1982; Brace et al., 1984; Brace et al. 1987). De acordo com esta hipótese, o pequeno dimorfismo sexual observado atualmente seria encontrado em populações que estiverem por mais tempo separadas dos seus ancestrais que dependeriam da caça de grandes animais para a sua sobrevivência durante o Pleistoceno (Brace et al., 1987). O dimorfismo teria diminuído porque a redução do tamanho corporal masculino teria sido mais rápida do que a do feminino, justamente apoiado na idéia de um relaxamento da pressão seletiva que atuava mais fortemente sobre os homens em decorrência da caça (Brace et al.,1987).

Nos últimos 3 milhões de anos o dimorfismo sexual do tamanho corporal 
dos hominíneos reduziu-se de 60\% (ainda visível nos gorilas e babuínos) para $10 \%$ nos humanos atuais (Brace \& Ryan, 1980). O dimorfismo dentário, especificamente, teria sido reduzido de 16 a $20 \%$ para apenas $4 \%$ nas populações menos dimórficas humanas atuais. Brace \& Ryan (1980) sugeriram que o dimorfismo dentário estaria mais relacionado e dependente da taxa de dimorfismo sexual corpóreo total; e que a redução ocorrida no final do Pleistoceno foi de duas formas, ou seja, no tamanho total dos dentes e no dimorfismo sexual dentário, sem que uma estivesse relacionada com a outra (Brace et al., 1987). Conforme já mensionado, a redução no tamanho total dos dentes estaria relacionada com 0 desenvolvimento de técnicas de processamento pré-oral do alimento, que atinguiu ambos os sexos igualmente (Brace et al., 1987). Já a redução no dimorfismo sexual teria sido provocada pela troca da caça de grandes animais por estratégias de subsistência que teriam relaxado a pressão seletiva sobre robustez (Brace et al., 1987). Outros autores também vêm retratando uma redução do tamanho dentário em diferentes partes do mundo (e.g. Perzigizn, 1976; Sharma, 1983; Yamada \& Brown, 1990).

Segundo Brace (1967), Brace \& Mahler (1971), Brace \& Ryan (1980), Brace et al. (1984) e Brace et al. (1987) pode ser observado um gradiente norte-sul na redução do tamanho dos dentes nas populações humanas atuais principalmente em decorrência de dois fatores principais: primeiro, porque as técnicas de preparação pré-oral dos alimentos tiveram origem nas regiões setentrionais e depois se difundiram para o sul, e, em segundo lugar, que as populações meridionais (principalmente aquelas mais a leste) teriam mantido 
por mais tempo a caça de animais de grande porte e, portanto, mantido por mais tempo a pressão seletiva sobre a robustez dos machos. McKee (1984), através de simulações computacionais, sugeriu que uma hipótese viável para a PME, seria a de um sistema poligênico para que fosse possível a redução deste traço quantitativo em um espaço de tempo limitado, ou seja, da redução dentária nas populações humanas nos últimos 40.000 anos.

De acordo com Calcagno \& Gibson (1988) o modelo PME sugere que estruturas não mais funcionais irão experimentar um relaxamento de pressão seletiva, permitindo um acúmulo mais rápido de mutações que irão inevitavelmente resultar em redução do tamanho ou em perda dessas estruturas. As críticas de Calcagno \& Gibson (1988) sobre a PME recaem sobre a idéia que de seria pouco racional assumir que certos dentes seriam objeto de um acúmulo mais rápido de mutações se um relaxamento geral da seleção ocorresse sobre o tamanho dentário. Se um dente é inútil, é possível supor que a seleção seria positivamente direcionada para a sua perda e não para a sua redução em tamanho. Em outras palavras, se um dente torna-se inútil seria mais adaptativo a sua ausência do que a sua redução, já que dentes pequenos estão suceptíveis aos mesmos males sofridos por dentes de tamanho normal (Calcagno \& Gibson, 1988).

A magnitude da correlação entre os diâmetros mesiodistal e bucolingual (Figura 11) das coroas dentárias é de considerável importância, já que uma alta correlação pode sugerir um único fator de "tamanho" que afetaria ambas as dimensões; já uma baixa correlação indicaria uma relativa autonomia dos fatores que controlam as duas dimensões. Hanihara \& Ishida (2005) 
demonstraram que os dois diâmetros são mais sistematicamente e significativamente correlacionados nas mulheres, e menos para os dentes inferiores do que para os superiores. Em números, apenas $26 \%$ da variação do tamanho dos dentes são determinados por fatores comuns, indicando que as duas dimensões variam de forma mais ou menos autônoma (Garn et al., 1967; Hanihara \& Ishida, 2005).

Como já foi dito, o dimorfismo sexual dos dentes humanos também tem sido extensivamente estudado através de análises odontométricas. A maioria desses estudos tem demonstrado diferenças estatisticamente significativas entre os sexos (Townsend, 1985 e 2003; Dempsey \& Townsend, 2001). Os caninos superiores apresentam as maiores diferenças sexuais, maiores quanto aos diâmetros mesiodistal e bucolingual (Garn et al., 1967; Lund, 2001; Dempsey \& Townsend, 2001; Townsend et al., 2003). A razão pela qual os caninos são mais dimórficos é incerta. Um grande número de hipóteses vem sendo proposto para explicar o fenômeno. A mais popular está relacionada com a função dos caninos, que evolutivamente é diferente dos demais dentes, por estar grandemente relacionado à agressividade (Lund, 2001). Porém, o dimorfismo sexual dentário não é igual em todas as populações humanas, sendo relativamente pequeno entre os japoneses e os aborígines australianos e maior nas demais populações (Hanihara, 1976). 


\section{Material e Métodos}

\subsection{Materiais}

Para a execução deste trabalho utilizaram-se as medidas odontométricas (mesiodistal e bucolingual) dos dentes dos paleoíndios de Lagoa Santa existentes nas coleções do Laboratório de Estudos Evolutivos Humanos da USP, do Museu Nacional da Universidade Federal do Rio de Janeiro, do Museu de História Natural da Universidade Federal de Minas Gerais - coleção Harold Walter e coleção Santa do Riacho -, e do Museu de História Natual da Universidade de Copenhaguen, Dinamarca.

Outra coleção foi inserida no trabalho com o intuito de validar o protocolo de medidas utilizado pelos dois observadores (Dr. Hanihara e eu) através das relações biológicas já conhecidas mundialmente. A coleção inserida é um subgrupo do material depositado no Museu de Anatomia Humana Professor Alfonso Bovero da Universidade de São Paulo, de japanoses vindos nas primeiras imigrações para o Brasil (1914 até 1934), tipicamente mongolóides.

O protocolo de medidas odontométricas utilizado foi o de Moorrees et al. (1957). As medidas são definidas como:

- O diâmetro mesiodistal (Figura 11) da coroa dos dentes é obtido pela medida da maior distancia entre os pontos de contato das superfícies dentárias adjacentes, paralela a ambas as superfícies dentárias, a oclusal e a vestibular. Este critério pode ser empregado somente quando o dente está em posição normal na arcada dentária. Caso isso não ocorra, o diâmetro mesiodistal é 
obtido pela medida dos dois pontos nos quais deveria ocorrer o contato com os dentes vizinhos.

- $\quad$ O diâmetro bucolingual (Figura 11) é facilmente obtido uma vez que o diâmetro mesiodistal foi estabelecido. É definido como sendo a maior distância entre as superfícies laterais labial e lingual, tomada perpendicularmente $\left(90^{\circ}\right)$ ao plano da medida mesiodistal.

Preferencialmente foram utilizados todos os dentes do lado esquerdo de para a realização das medições. Caso um os dentes estivesse ausente do lado esquerdo, foi substituído pelo seu antímero. Tal procedimento permitiu maximizar o tamanho das amostras e ao mesmo tempo manter o indivíduo e não o dente como unidade de estudo. Este é um procedimento padrão utilizado em trabalhos de odontometria e está alicerçado na existência de uma alta correlação entre os antímeros (variando de 0.85 a 0.97 ) para os dentes decíduos e de 0.87 a 0.96 para os dentes permanentes (Barrett et al., 1963; Barrett et al., 1964; Moorrees \& Reed, 1964).

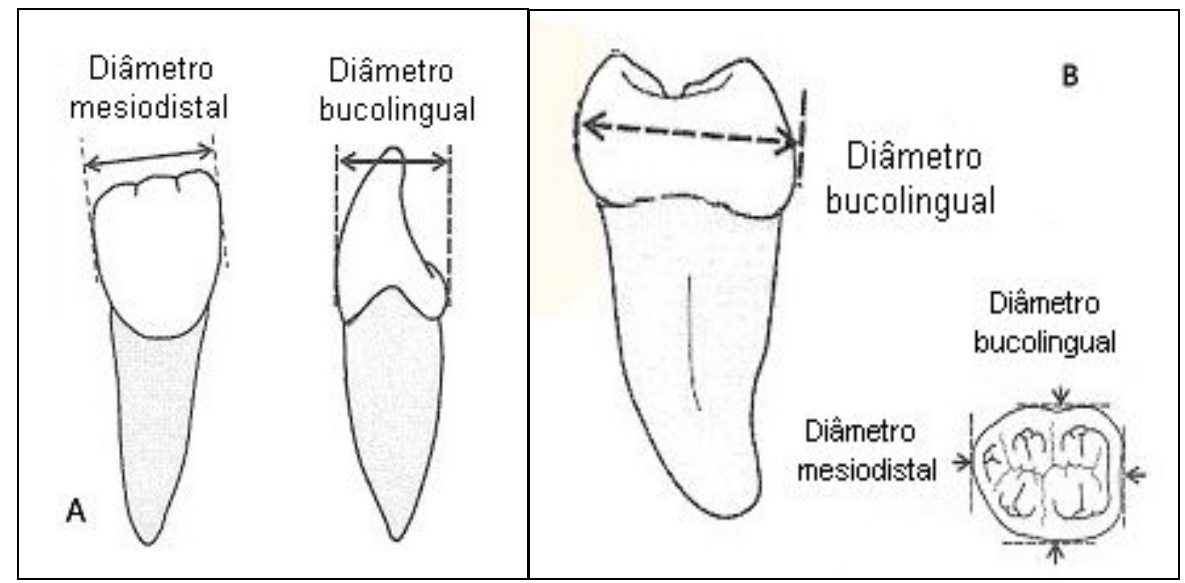

Figura 11 - Medidas dentárias 1A- diâmetros mesiodistal e bucolingual em incisivos; 1B- diâmetros mesio-distal e buco-lingual em molares. 


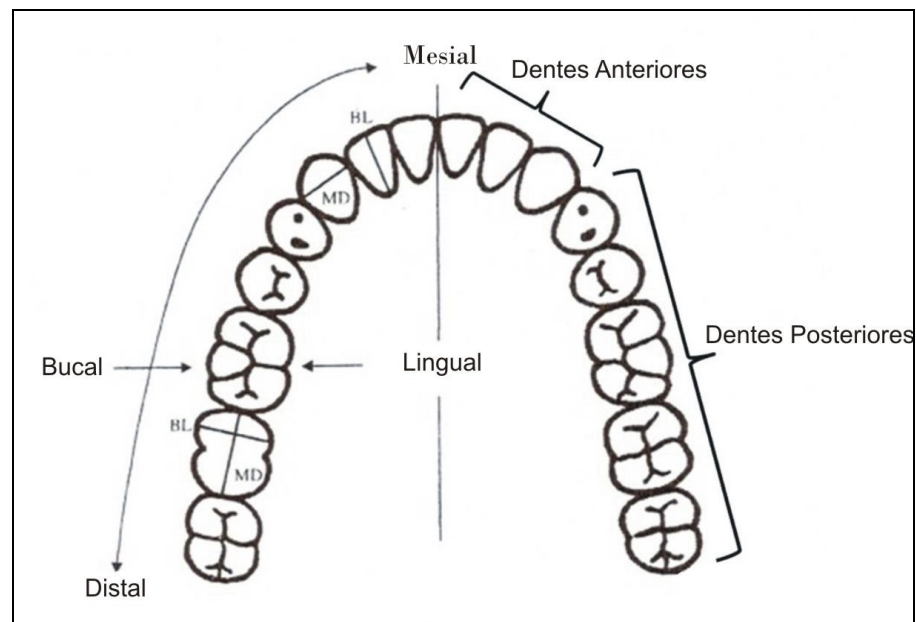

Figura 12 - Exemplo esquemático das medidas tomadas em uma arcada e orientações anatômicas utilizadas como referência.

A análise contemplou 32 variáveis odontométricas, ou seja, as medidas mesiodistal (MD) e bucolingual (BL), de todas as categorias dentárias - incisivos (I), pré-molares (PM) e molares (M). Dentes com variações morfológicas peculiares, patológicos ou danificados foram excluídos do banco (Hanihara, informação pessoal). As demais notações utilizadas referem-se à definição exata do dente: centrais ou primeiro 1 e laterais ou segundo 2 e terceiro 3, para os casos nos quais existem mais de um dente de um mesmo tipo dentário; e superiores U e inferiores L. Todas as notações utilizadas são apresentadas na Tabela 1.

Tabela 1 - Variáveis odontométricas utilizadas neste estudo, baseadas em Morreess et al., 1957.

\begin{tabular}{|c|c|c|c|}
\hline \multicolumn{2}{|c|}{ Variáveis maxilares ou superiores } & \multicolumn{2}{|c|}{ Variáveis mandibulares ou inferiores } \\
\hline Descrição & Abreviatura & Descrição & Abreviatura \\
\hline $\begin{array}{c}\text { Mesiodistal do Incisivo } \\
\text { Central Superior }\end{array}$ & MD I 1 U & $\begin{array}{c}\text { Mesiodistal do Incisivo } \\
\text { Central Inferior }\end{array}$ & MD I 1 L \\
\hline $\begin{array}{c}\text { Mesiodistal Incisivo } \\
\text { Lateral Superior }\end{array}$ & MD I 2 U & $\begin{array}{l}\text { Mesiodistal Incisivo } \\
\text { Lateral Inferior }\end{array}$ & MD I 2 L \\
\hline $\begin{array}{c}\text { Mesiodistal } \\
\text { Canino Superior }\end{array}$ & MD C 1 U & $\begin{array}{c}\text { Mesiodistal } \\
\text { Canino Inferior }\end{array}$ & MD C 1 L \\
\hline $\begin{array}{l}\text { Mesiodistal Primeiro } \\
\text { Pré-molar Superior }\end{array}$ & MD PM 1 U & $\begin{array}{l}\text { Mesiodistal Primeiro } \\
\text { Pré-molar Inferior }\end{array}$ & MD PM 1 L \\
\hline
\end{tabular}


(Continuação) Tabela 1 - Variáveis odontométricas utilizadas neste estudo, baseadas em Morreess et al., 1957.

\begin{tabular}{|c|c|c|c|}
\hline \multicolumn{2}{|c|}{ Variáveis maxilares ou superiores } & \multicolumn{2}{|c|}{ Variáveis mandibulares ou inferiores } \\
\hline Descrição & Abreviatura & Descrição & Abreviatura \\
\hline $\begin{array}{l}\text { Mesiodistal Segundo } \\
\text { Pré-molar Superior }\end{array}$ & MD PM 2 U & $\begin{array}{l}\text { Mesiodistal Segundo } \\
\text { Pré-molar Inferior }\end{array}$ & MD PM 2 L \\
\hline $\begin{array}{l}\text { Mesiodistal Primeiro } \\
\text { Molar Superior }\end{array}$ & MD M 1 U & $\begin{array}{l}\text { Mesiodistal Primeiro } \\
\text { Molar Inferior }\end{array}$ & MD M 1 L \\
\hline $\begin{array}{l}\text { Mesiodistal Segundo } \\
\text { Molar Superior }\end{array}$ & MD M 2 U & $\begin{array}{l}\text { Mesiodistal Segundo } \\
\text { Molar Inferior }\end{array}$ & MD M 2 L \\
\hline $\begin{array}{l}\text { Mesiodistal Terceiro } \\
\text { Molar Superior }\end{array}$ & MD M 3 U & $\begin{array}{l}\text { Mesiodistal Terceiro } \\
\text { Molar Inferior }\end{array}$ & MD M 3 L \\
\hline $\begin{array}{l}\text { Bucolingual do Incisivo } \\
\text { Central Superior }\end{array}$ & BL I 1 U & $\begin{array}{l}\text { Bucolingual do Incisivo } \\
\text { Central Inferior }\end{array}$ & BL \\
\hline $\begin{array}{l}\text { Bucolingual Incisivo } \\
\text { Lateral Superior }\end{array}$ & BL I 2 U & $\begin{array}{l}\text { Bucolingual Incisivo } \\
\text { Lateral Inferior }\end{array}$ & BL I 2 L \\
\hline $\begin{array}{l}\text { Bucolingual Canino } \\
\text { Superior }\end{array}$ & BL & $\begin{array}{l}\text { Bucolingual Canino } \\
\text { Inferior }\end{array}$ & BL C 1 L \\
\hline $\begin{array}{l}\text { Bucolingual Primeiro } \\
\text { Pré-molar Superior }\end{array}$ & BL PM 1 U & $\begin{array}{l}\text { Bucolingual Primeiro } \\
\text { Pré-molar Inferior }\end{array}$ & BL PM 1 L \\
\hline $\begin{array}{l}\text { Bucolingual Segundo } \\
\text { Pré-molar Superior }\end{array}$ & BL PM 2 U & $\begin{array}{l}\text { Bucolingual Segundo } \\
\text { Pré-molar Inferior }\end{array}$ & BL PM 2 L \\
\hline $\begin{array}{l}\text { Bucolingual Primeiro } \\
\text { Molar Superior }\end{array}$ & BL M 1 U & $\begin{array}{l}\text { Bucolingual Primeiro } \\
\text { Molar Inferior }\end{array}$ & BL M 1 L \\
\hline $\begin{array}{l}\text { Bucolingual Segundo } \\
\text { Molar Superior }\end{array}$ & BL M 2 U & $\begin{array}{l}\text { Bucolingual Segundo } \\
\text { Molar Inferior }\end{array}$ & BL M 2 L \\
\hline $\begin{array}{l}\text { Bucolingual Terceiro } \\
\text { Molar Superior }\end{array}$ & BL M 3 U & $\begin{array}{l}\text { Bucolingual Terceiro } \\
\text { Molar Inferior }\end{array}$ & BL M 3 L \\
\hline
\end{tabular}

Dentes com desgaste interproximal e oclusal extremos também foram desconsiderados. O desgaste interproximal ocorre naturalmente através do contato entre dentes vizinhos, na região denominada de ponto de contato. no entanto em leve intensidade, deixando somente um sinal no dente da região onde existia o toque entre dentes. Desgastes interproximais que apresentavam perda de esmalte mais acentuada, ou seja, qualquer desgaste maior do que 0 normalmente observado pelo ponto de contato entre dentes, foram excluídos. Para o desgaste oclusal, quando se trataram dos dentes pré-molares e molares o limite tolerado foi o equador do dente (região do diâmetro máximo 
mesiodistal e bucolingual) (Figura 13b). Para o desgaste oclusal dos caninos e dos incisivos, nos quais os diâmetros máximos são muito próximos da superfície oclusal, a tolerância adotada foi maior. O relaxamento no desgaste tolerado deve-se à natureza do material analisado, de origem arqueológica de considerável profundidade temporal, e conseqüentemente com desgaste intenso. No caso dos dentes incisivos e caninos, o critério foi mais subjetivo, no qual foram evitados desgastes considerados extremos e muito comprometedores do diâmetro dos dentes (Figura 13a).

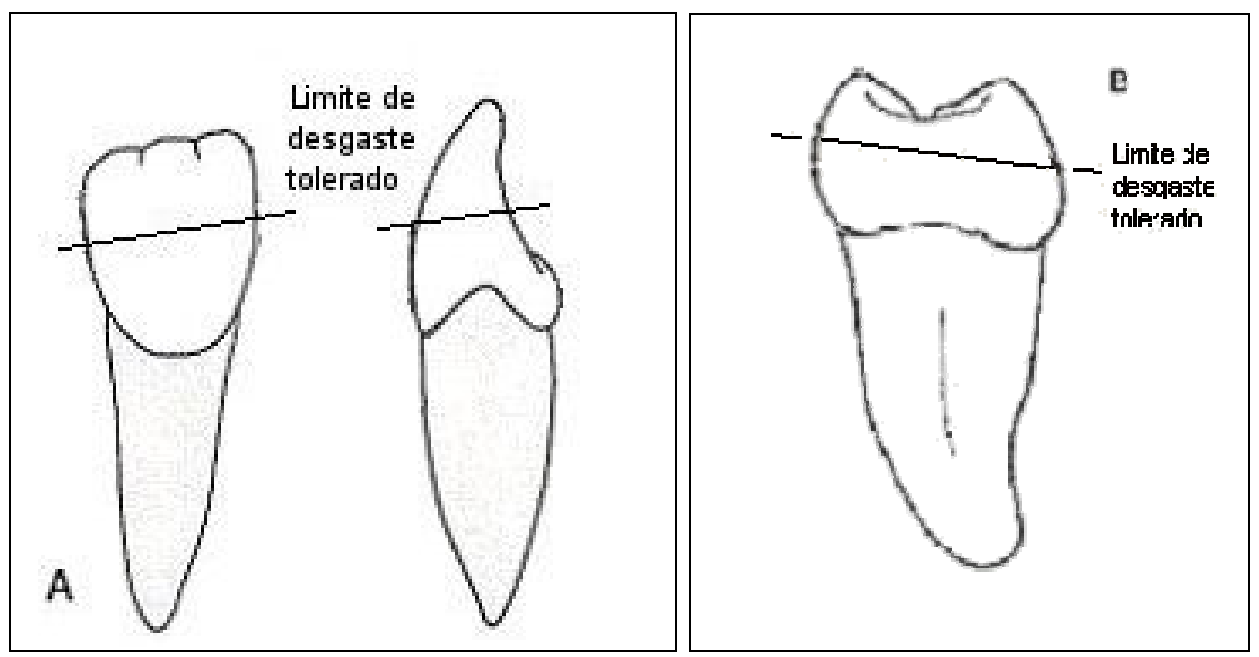

Figura 13 - Limite de desgaste tolerado para a tomada das medidas. A: limite para dentes incisivos e caninos e B: limite para dentes pré-molares e molares.

\subsection{Métodos Odontométricos:}

\subsubsection{O banco de dados odontométricos de Hanihara}

O bando de dados odontométricos organizado pelo Dr. Tsunehiko Hanihara, do Departamento de Anatomia, da Escola de Medicina de Saga no Japão, foi divulgado para a comunidade científica apenas em 2005. O artigo intitulado: "Metric Dental Variation of Major Human Populations" publicado no 
American Journal of Physical Anthropology (volume 128, pgs. 287-298) apresentou as afinidades biológicas mundiais baseadas em um banco de dados representativo e aparentemente robusto (Tabela 2 ).

Tabela 2 - Distribuição das populações masculinas e femininas utilizadas neste trabalho segundo divisão sugerida por Hanihara \& Ishida (2005)*

\begin{tabular}{|c|c|c|c|c|}
\hline $\begin{array}{r}\text { Grandes Regiões } \\
\text { Geográficas }\end{array}$ & $\begin{array}{c}\text { Grupos } \\
\text { Populacionais }\end{array}$ & $\begin{array}{c}N^{* *} \\
\text { masc }\end{array}$ & $N^{* *}$ & Unidade Populacional \\
\hline \multirow[t]{11}{*}{ East Asia } & Japanese & 50 & 40 & Tohoku \\
\hline & & & & Kanto regions \\
\hline & & & & Northern parte of Honshu \\
\hline & Ainu & 102 & 81 & Hokaido \\
\hline & & & & Sakhalin Island \\
\hline & Jomon & 131 & 75 & Prehistoric (neolithic) Japan \\
\hline & & & & Middle to the latest Jomons periods \\
\hline & Northern Chinese & 69 & 11 & From north of Cheng Kiang River \\
\hline & Southern Chinese & 64 & - & From south of Cheng Kiang River \\
\hline & Tibetans/Nepalese & 65 & 14 & Tibet \\
\hline & & & & Nepal \\
\hline \multirow{8}{*}{ Northeast Asia } & Mongol/ Buryats & 140 & 85 & Tibet (lowland) \\
\hline & & & & Nepal (lowland) \\
\hline & & & & Ulan Bator \\
\hline & & & & Mongol/Troiskosavsk \\
\hline & & & & Buryats \\
\hline & Chukchis/NE Asia & 21 & - & Chukchis \\
\hline & & & & Evenki Yukagirs \\
\hline & & & & Yakuts \\
\hline \multirow[t]{23}{*}{ Southeast Asia } & Vietnam/Thailand & 68 & - & Saigon \\
\hline & & & & Bangkok \\
\hline & & & & Vietnam \\
\hline & & & & Thailand \\
\hline & Myanmar & 103 & - & Arakan Hill \\
\hline & & & & Rangoon \\
\hline & & & & Karen \\
\hline & & & & Myanmar \\
\hline & Malay & 54 & & Singapore \\
\hline & Early SE Ásia & 76 & 39 & Neolhitic Malay \\
\hline & & & & Gua Cha \\
\hline & & & & Neolithic Vietnam \\
\hline & & & & Neolithic Laos \\
\hline & & & & Bang Chang site, early Iron Age, Thailand \\
\hline & Andaman/Nicobar & 75 & 26 & Recent Andamanese (Onge, Jarawa, etc) \\
\hline & & & & Nicobarese \\
\hline & Java/Sumatra & 102 & 11 & including nias \\
\hline & & & & Biliton \\
\hline & & & & Mentawei Islands \\
\hline & & & & Batavia \\
\hline & & & & Madura \\
\hline & & & & Fagal \\
\hline & & & & Pekalongan \\
\hline
\end{tabular}


(Continuação) Tabela 2 - Distribuição das populações masculinas e femininas utilizadas neste trabalho segundo divisão sugerida por Hanihara \& Ishida (2005)*

\begin{tabular}{|c|c|c|c|c|}
\hline $\begin{array}{c}\text { Grandes Regiões } \\
\text { Geográficas }\end{array}$ & $\begin{array}{c}\text { Grupos } \\
\text { Populacionais }\end{array}$ & $\begin{array}{c}\mathrm{N}^{* *} \\
\text { masc }\end{array}$ & $\begin{array}{l}N^{* *} \\
\text { fem }\end{array}$ & Unidade Populacional \\
\hline \multirow[t]{4}{*}{ Southeast Asia } & Borneo & 109 & 12 & $\begin{array}{l}\text { Land Dayaks includins } \\
\text { Iban Sea Dayaks }\end{array}$ \\
\hline & Philippines & 107 & 21 & $\begin{array}{l}\text { Non-negrito filipinos from } \\
\text { Luzon } \\
\text { Palawan } \\
\text { Panay } \\
\text { Negrões } \\
\text { Mindanao }\end{array}$ \\
\hline & Lesser Sunda & 55 & - & $\begin{array}{l}\text { Bali } \\
\text { Sumbawa } \\
\text { Flores } \\
\text { Timor Islands } \\
\text { Celebre Islands } \\
\text { Molucca Islands } \\
\text { Aeta }\end{array}$ \\
\hline & Negritos & 44 & 12 & $\begin{array}{l}\text { Luzon } \\
\text { Philippines }\end{array}$ \\
\hline \multirow[t]{2}{*}{ Arctic } & Aleutian Islands & 78 & 32 & $\begin{array}{l}\text { Unalaska } \\
\text { Unga } \\
\text { Umnak } \\
\text { Shiplock } \\
\text { Amaknak } \\
\text { Kagamil } \\
\text { Atka } \\
\text { Kanaga } \\
\text { Amlia } \\
\text { Adak } \\
\text { Amchitka } \\
\text { Kiska } \\
\text { Attu } \\
\text { Agatu Islands }\end{array}$ \\
\hline & Eskimos & 147 & 115 & $\begin{array}{l}\text { Lower Yukon River basin } \\
\text { Seward Peninsula } \\
\text { Point Barrow around Baffin Bay } \\
\text { Somerset Islands } \\
\text { Prince of Wales } \\
\text { Victoria Islands } \\
\text { Greenland }\end{array}$ \\
\hline \multirow[t]{2}{*}{ North America } & Plateau/Grea Basin & 32 & - & $\begin{array}{l}\text { Washington } \\
\text { Oregon } \\
\text { Utah } \\
\text { Colorado } \\
\text { Wyoming } \\
\text { Nevada }\end{array}$ \\
\hline & California & 64 & 36 & $\begin{array}{l}\text { Sacramento Angel Island } \\
\text { San Nicolas Islands } \\
\text { Angels Bay } \\
\text { Santa Bárbara } \\
\text { Santa Rosa Islands } \\
\text { Santa Cruz Island }\end{array}$ \\
\hline
\end{tabular}


(Continuação) Tabela 2 - Distribuição das populações masculinas e femininas utilizadas neste trabalho segundo divisão sugerida por Hanihara \& Ishida (2005)*

\begin{tabular}{cccc}
$\begin{array}{c}\text { Grandes Regiões } \\
\text { Geográficas }\end{array}$ & $\begin{array}{c}\text { Grupos } \\
\text { Populacionais }\end{array}$ & $\begin{array}{c}\mathbf{N}^{* *} \\
\text { masc }\end{array}$ & $\begin{array}{c}\mathbf{N}^{* *} \\
\text { fem }\end{array}$ \\
\hline
\end{tabular}

North America

Southwest

51

\begin{tabular}{|c|c|c|c|c|}
\hline \multirow[t]{36}{*}{ North America } & Southwest & 51 & 29 & Arizona \\
\hline & & & & New México \\
\hline & Plains/North & 57 & 45 & North Dakota \\
\hline & & & & South Dakota \\
\hline & & & & Montana \\
\hline & & & & lowa \\
\hline & & & & Nebraska \\
\hline & Plains/South & 38 & 26 & Kansas \\
\hline & & & & Missouri \\
\hline & & & & Arkansas \\
\hline & & & & Texas \\
\hline & & & & Oklahoma \\
\hline & Northeastern & & & \\
\hline & Woodland/West & 39 & 23 & Illinois \\
\hline & & & & Michigan \\
\hline & & & & Wisconsin \\
\hline & & & & Indiana \\
\hline & & & & Ohio \\
\hline & Northeastern & & & \\
\hline & Woodland/East & 51 & 33 & New York \\
\hline & & & & Massachusetts \\
\hline & & & & Connecticut \\
\hline & & & & New Jersey \\
\hline & & & & Pennsylvania \\
\hline & & & & Delaware \\
\hline & & & & Maryland \\
\hline & & & & Kentucky \\
\hline & Southeastern & & & \\
\hline & Woodland & 59 & 46 & Virginia \\
\hline & & & & Tennessee \\
\hline & & & & Georgia \\
\hline & & & & Alabama \\
\hline & & & & North and South Carolina \\
\hline & & & & Louisiana \\
\hline & & & & Mississippi \\
\hline & & & & Florida \\
\hline \multirow{3}{*}{ Central \& South America } & México & 57 & 23 & recent Mexico Indians including \\
\hline & Peru & 172 & 64 & recent peruvians \\
\hline & Fuegians/Patagonias & 33 & - & $\begin{array}{l}\text { Terra del Fuego } \\
\text { Patagonia region }\end{array}$ \\
\hline \multirow[t]{5}{*}{ Australia } & Australia/East & 78 & 20 & Queensland \\
\hline & & & & $\begin{array}{l}\text { New South Wales } \\
\text { Victoria }\end{array}$ \\
\hline & Australia/South & 175 & 50 & Near Adelaide \\
\hline & & & & Murray River Basin \\
\hline & Australia/North \& West & 26 & & Northern Territory Western Australia \\
\hline \multirow[t]{4}{*}{ Melanesia } & Papua New Guinea & 245 & 120 & Purari River \\
\hline & & & & Fly River \\
\hline & & & & Sepik River \\
\hline & & & & Including Torres Strait \\
\hline
\end{tabular}

Unidade Populacional 
(Continuação) Tabela 2 - Distribuição das populações masculinas e femininas utilizadas neste trabalho segundo divisão sugerida por Hanihara \& Ishida (2005)*

$\begin{array}{cccc}\text { Grandes Regiões } & \text { Grupos } & \mathbf{N}^{* *} & \mathbf{N}^{* *} \\ \text { Geográficas } & \text { Populacionais } & \text { masc } & \text { fem }\end{array}$

Geográficas

West Melanesia

$135 \quad 59$

Unidade Populacional

Melanesia

West Melanesia

BismarckArchipelago

New Ireland

East Melanesia

127

New Britains

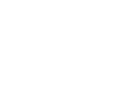

Micronesia

Mariana Islands

86

olomon

New Caledonia

Vanuatu

Fiji

(n)

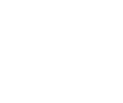

Polinesia

Society

Cook

Maori/Miriori

Marquesas

87

64

Guan Islands

Saipan Islands

Tinian Islands

Caroline Islands

34

Yap Islands

Palau Islands

Ponap Islands

Posia

South Asia

India/North

184

Tahiti

64 - Manuai

Atiu

Titiaroa

Mangaia Islands

New Zealand

Chatham Islands

Hatua Tua

Nuku Hiva

Ua Huka

Fatu Hiva

Oahu/Hawaii

14698 Mokapu site

Maui-Molakai/Hawaii

Lanai

Hawaii/Hawaii

50

Kauai

Kona site

H1 Site

Hawaii Island

South Asia

West Asia

Afghanistan/Pakistan

37

Bengal

Behar

Orissa

Bombay

Punjab

Kashimir

India/South

103

Madrs

Malabar

Mysore

Helman Valley

Mogul

Kandahar

Kotal

Priest

Pecheen Valley

Kalati

Pamir Plat., including a few specimes from West Ásia 
(Continuação) Tabela 2 - Distribuição das populações masculinas e femininas utilizadas neste trabalho segundo divisão sugerida por Hanihara \& Ishida (2005)*

$\begin{array}{cccc}\text { Grandes Regiões } & \text { Grupos } & \mathbf{N}^{* *} & \mathbf{N}^{* *} \\ \text { Geográficas } & \text { Populacionais } & \text { masc } & \text { fem }\end{array}$

Geográficas

Populacionais

masc fem

\section{Unidade Populacional}

\begin{tabular}{|c|c|c|c|c|}
\hline \multirow[t]{2}{*}{ West Asia } & Turkey/Cyprus & 252 & $\begin{array}{l}- \\
-\end{array}$ & $\begin{array}{l}\text { Adevis } \\
\text { Marash } \\
\text { Aintab } \\
\text { Adalea } \\
\text { Ephesos } \\
\text { Kurd } \\
\text { Mohammedan } \\
\text { Armenian: Hellenismic period of Cyprus }\end{array}$ \\
\hline & Early Iran/Israel & 46 & - & $\begin{array}{l}\text { Tell Duweir (Lachish) } \\
\text { Bronze and Iron Age } \\
\text { Israel/Bronze to Achaemenian period of Iran }\end{array}$ \\
\hline \multirow[t]{2}{*}{ North Africa } & Egypt/Predinasty & 92 & - & $\begin{array}{l}\text { Badari } \\
\text { Naqada }\end{array}$ \\
\hline & Egypt/12-29th Dynasty & 115 & 20 & $\begin{array}{l}\text { Lisht } \\
\text { Cairo } \\
\text { Omdurman } \\
\text { Gizeh }\end{array}$ \\
\hline \multirow[t]{6}{*}{ Europe } & Greek & 34 & - & $\begin{array}{l}\text { ancient and recent greek } \\
\text { Cyrene } \\
\text { Rhodes } \\
\text { Corfu } \\
\text { Athens } \\
\text { Attica }\end{array}$ \\
\hline & Russia & 48 & - & $\begin{array}{l}\text { Crimea Courland } \\
\text { Latvia } \\
\text { Pskoff } \\
\text { Uzbekistan } \\
\text { Odessa } \\
\text { Tambow }\end{array}$ \\
\hline & Czecho & 74 & - & $\begin{array}{l}\text { Charvaty, near Olomouc, Central Moravia } \\
\text { including a few samples from East Europe }\end{array}$ \\
\hline & Hungary & 44 & 23 & $\begin{array}{l}\text { Demko-Hegy } \\
\text { Czakbereny } \\
\text { Roman Period } \\
\text { Demko-Hegy 11-12th centuries } \\
\text { Nagy-sap } \\
\text { Csakover 11th century } \\
\text { Stuhlweisenberg } \\
\text { Presburg }\end{array}$ \\
\hline & Germany & 62 & - & $\begin{array}{l}\text { Berlin } \\
\text { Mainz } \\
\text { Holstein } \\
\text { Westphalia }\end{array}$ \\
\hline & Austria/Swiss & 32 & - & $\begin{array}{l}\text { Tirol } \\
\text { St. Peter above Tweng } \\
\text { Carinthia 16-17th centuries } \\
\text { Malta } \\
\text { Millstatt } \\
\text { Carinthia 16-17th centuries }\end{array}$ \\
\hline
\end{tabular}


(Continuação) Tabela 2 - Distribuição das populações masculinas e femininas utilizadas neste trabalho segundo divisão sugerida por Hanihara \& Ishida (2005)*

\section{Grandes}

Regiões

Grupos $\quad \mathbf{N}^{* *} \quad \mathbf{N}^{* *}$

Geográficas Populacionais masc fem

Europe

Austria/Swiss

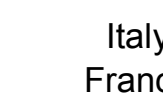

France

UK/Esay

UK/Poundbury

UK/Spitalfields 1

UK/Spitalfields2

Finland / Ural

Sub-Saharan Africa
Nigeria/Ghana

Somalia

Kenya

Tanzania

South Africa

s

masc fem

Raach near Gloggnitz
Modling near Vienna

Vienna/Austria

Lenz

Canton

Grissons/Switzerland

15 - Ancient and recent italians

59 - Merovingian

Gallo-Roman

Late Medieval to Post-Medieval periods,

$75 \quad$ Scotland

$77 \quad$ - $\quad$ Late Roman period Southwest England

$7355 \quad$ Mid-Victorian period London

12247 Pre-17th century London

$153 \quad 16 \quad$ Ibo

Ashanti tribes

$72 \quad$ - $\quad$ Erigravo Dsitric

Ogaden Somali

$96 \quad 24 \quad$ Ngorongo

Turkana

Kikuyu

Kaurite to Fort Hall

127

15 Tanganika Territory

Loe

Haya Tribe

123

Zulu nad oncec

* A nomenclatura das populações foi mantida em inglês de acordo com o apresentado por Hanihara \& Ishida (2005)

**N dos intervalos de tamanho, distribuição de $\mathrm{N}$ nas amostras populacionais, já que cada uma das características observadas tem um $\mathrm{N}$ diferente.

A Tabela 2 traz os agrupamentos e o número de indivíduos por população utilizados nas análises estatísticas deste trabalho, ainda de acordo com os agrupamentos propostos por Hanihara \& Ishida (2005). O referido trabalho utiliza somente a parcela masculina do banco de dados, e a classificação da parcela feminina foi realizada aplicando o mesmo agrupamento proposto para a parcela masculina. No entanto é possível observar que diversas populações apresentam tamanho amostral muito reduzido. Este tamanho amostral reduzido $(\mathrm{N}<20)$ para o número de variáveis utilizadas neste trabalho 
(32 variáveis) de acordo com as premissas estatísticas (Hair et al., 2005) não deve ser utilizado. Isto trás à tona um problema, já que a parcela feminina é muito menor que o banco masculino (7223 homens e 2146 mulheres subdivididos em 161 e 60 populações, respectivamente).

O procedimento adotado para a apuração do banco de dados tanto masculino quanto feminino aqui utilizados seguiu os seguintes passos de exclusão de populações/indivíduos e/ou variáveis do banco original e completo:

1) todos os indivíduos com menos de cinco variáveis;

2) populações que apresentavam ausência de valor em alguma variável;

3) populações com somente um indivíduo;

4) populações selecionadas por Hanihara \& Ishida (2005).

Neste ponto o banco de dados foi reduzido para 5899 homens subdivididos em 71 populações todas com pelo menos 21 indivíduos (as duas populações masculinas excluídas foram Chukchis/NE Ásia e Finland/Ural) e 1715 mulheres, subdivididas em 42 populações. As 28 populações femininas excluídas até este ponto do processo foram: Afghanistan/Pakistan, Austrália North/West, Áustria/Swiss, Caroline Islands, Chukchis/NE Ásia, Cook, Czecho, Early Iran/Israel, Egypt/Predynasty, Finland/Ural, France, Fueginos/Patagonians, Germany, Greek, Italy, Lesser Sunda, Malay, Maori/Moriori, Myanmar, Plateaus/Great Basin, Rússia, Society, Somalia, South África, Southern China, UK/Ensay, UK/Poundbury e Vietnam/Thailand. Caso as populações com menos de 20 indivíduos tivessem sido retirados do banco de dados como proposto por Brace \& Hunt (1990), o banco de dados feminino 
encerraria com a modesta quantia de 1604 mulheres subdivididas em apenas 33 populações (perdendo as seguintes populações adicionais: Borneo, Hawaii/Hawaii, India/South, Java/Sumatra, Negritos, Nigeria/Ghana, North China, Tanzânia e Tibetans/Nepalese), uma parcela ínfima do que representa o banco de dados masculino. Conseqüentemente, as inferências que foram realizadas a partir da parcela feminina são menos confiáveis já que sua representatividade é muito menor.

Tabela 3 - Exemplo de arquivo sem formatação recebido do Dr. Haniraha

\begin{tabular}{lllllllll}
\multicolumn{1}{l}{ Kagamil, Unalaska, Unga, Hog, Umnak, Attu, Shiplock, Agatu, Amchitka, Kiska, Kanaga, Amlia, Adak, Atka Islands / Aleutian Islands } \\
\hline \hline 32 & & & & & & & & \\
32 & & & & & & & & \\
no-number & 0.00 & 7.28 & 8.58 & 0.00 & 0.00 & 10.63 & 0.00 & 0.00 \\
& 0.00 & 0.00 & 0.00 & 0.00 & 0.00 & 0.00 & 0.00 & 0.00 \\
& 0.00 & 6.23 & 8.28 & 0.00 & 0.00 & 10.97 & 0.00 & 0.00 \\
377897 & 0.00 & 0.00 & 0.00 & 0.00 & 0.00 & 0.00 & 0.00 & 0.00 \\
& 0.00 & 6.91 & 7.79 & 0.00 & 0.00 & 10.53 & 9.81 & 0.00 \\
& 0.00 & 0.00 & 0.00 & 0.00 & 0.00 & 0.00 & 0.00 & 0.00 \\
243976 & 0.00 & 6.94 & 8.42 & 0.00 & 0.00 & 11.69 & 11.66 & 0.00 \\
& 0.00 & 0.00 & 0.00 & 0.00 & 0.00 & 0.00 & 0.00 & 0.00 \\
& 0.00 & 0.00 & 0.00 & 0.00 & 0.00 & 10.55 & 9.64 & 0.00 \\
242939 & 0.00 & 0.00 & 0.00 & 0.00 & 0.00 & 0.00 & 0.00 & 0.00 \\
& 0.00 & 0.00 & 0.00 & 0.00 & 0.00 & 11.14 & 10.79 & 0.00 \\
& 0.00 & 0.00 & 0.00 & 0.00 & 0.00 & 0.00 & 0.00 & 0.00 \\
& 0.00 & 0.00 & 0.00 & 7.16 & 0.00 & 10.80 & 10.09 & 9.30 \\
& 0.00 & 0.00 & 0.00 & 0.00 & 0.00 & 0.00 & 0.00 & 0.00 \\
& 0.00 & 0.00 & 0.00 & 0.00 & 0.00 & 11.31 & 11.04 & 10.65 \\
& 0.00 & 0.00 & 0.00 & 0.00 & 0.00 & 0.00 & 0.00 & 0.00 \\
\hline
\end{tabular}

A Tabela 3 apresenta um exemplo dos arquivos enviados por Hanihara, enquanto a Tabela 4 o arquivo explicativo enviado pelo mesmo. Foram formatadas todas as 379 planilhas para o padrão adotado pelo Laboratório de Estudos Evolutivos Humanos, mais adequado à aplicação dos testes estatísticos disponíveis em pacotes computacionais (para um exemplo da formatação final ver Tabela 5). Foi realizada intensa checagem visando evitar erros de importação de dados. Os dados masculinos e femininos foram agrupados em 
duas grandes planilhas de dados (excell) para que pudessem sofrer 0 tratamento estastístico adequado às análises propostas por este trabalho.

Tabela 4 - Arquivo informativo sobre o Banco de Dados Hanihara Datafile information

\section{Dental Measurements}

Mesiodistal and buccolingual dental measurements

1-8: mesiodistal measurements of Upper I1 - M3

9-16: mesiodistal measurements of Lower I1 - M3

17-24: buccolingual measurements of Upper I1 - M3

25-32: buccolingual measurements of Lower I1 - M3

\section{Datafile construction}

Datafile ID (brief information of the samples)

Number of samples (NS)

Number of Variables (NV=32)

Data set

ID number (specimen's number), Measurement data (1-32)

File name

F-: Female

M-: Male

CA: Canada

CSA: Central and South America

EA: East Asia

EU: Europe

MEL: Melanesia

MIC: Micronesia

NA: North Africa

NEA: Northeast Asia

POL: Polynesia

SEA: Southeast Asia

SSA: Subsaharan Africa

SWA: South and West Asia

UK: United Kingdom

US: United States

Aleut

Australia

Eskimo

India

Papua New Guinea 


\section{Tabela 5 - Formatação final de uma única população do banco de dados Hanihara, a título de exemplo}

DATA FILE (brief information

\section{the samples}

Kagamil, Unalaska, Unga, Hog, Umnak, Attu, Shiplock, Agatu, Amchitka, Kiska, Kanaga, Amlia, Adak, Atka Islands / Aleutian Islands

NUMBER OF SAMPLES (NS) 32.00

NUMBER OF VARIABLES $(\mathrm{NV}=32)$

32.00

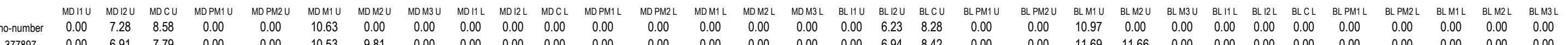

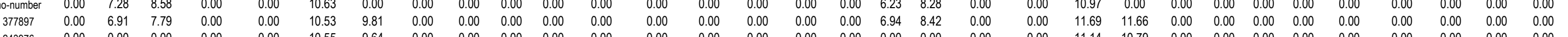

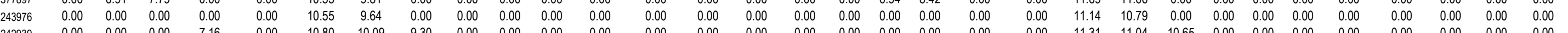

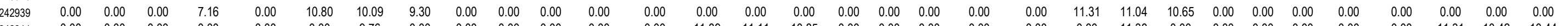

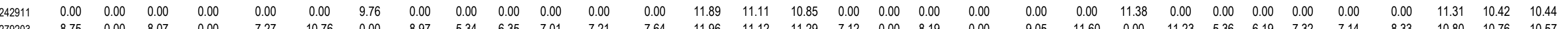

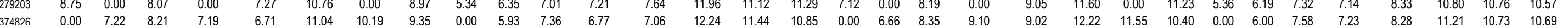

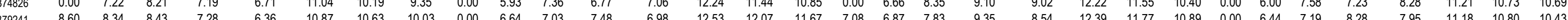

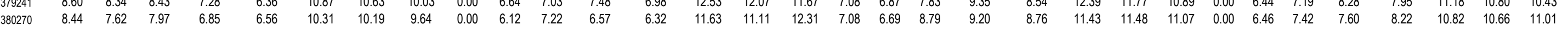

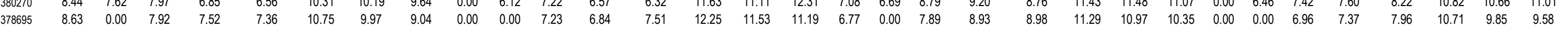
\begin{tabular}{lllllllllllll}
378695 & 8.63 & 0.00 & 7.92 & 7.52 & 7.36 & 10.75 & .97 & 9.04 & 0.00 & 0.00 & 7.23 & 0.84 \\
\hline
\end{tabular} $\begin{array}{lllllllllllll}377865 & 0.00 & 0.00 & 0.00 & 0.00 & 7.62 & 10.86 & 10.14 & 0.00 & 0.00 & 0.00 & 0.00 & 0.00\end{array}$ $\begin{array}{lllllllllllll}378417 & 10.28 & 9.22 & 8.50 & 8.01 & 7.48 & 11.83 & 10.48 & 10.02 & 0.00 & 0.00 & 0.00 & 0.00 \\ 377863 & 7.85 & 6.55 & 6.84 & 6.45 & 5.84 & 9.75 & 8.57 & 8.68 & 4.94 & 5.38 & 6.34 & 6.25\end{array}$ $\begin{array}{lllllllllllll}377863 & 7.85 & 6.55 & 6.84 & 6.45 & 5.84 & 9.75 & 8.57 & 8.68 & 4.94 & 5.38 & 6.34 & 6.25 \\ 377867 & 0.00 & 0.00 & 7.91 & 6.96 & 0.00 & 10.37 & 9.62 & 8.20 & 0.00 & 0.00 & 0.00 & 0.00\end{array}$ $\begin{array}{lllllllllllll}377811 & 0.00 & 0.00 & 0.00 & 7.62 & 0.00 & 11.32 & 9.96 & 9.02 & 5.69 & 6.52 & 7.73 & 7.35\end{array}$ $\begin{array}{lllllllllllll}377809 & 0.00 & 8.60 & 8.92 & 8.47 & 7.83 & 10.67 & 10.56 & 8.11 & 5.91 & 6.86 & 0.00 & 7.80\end{array}$ $\begin{array}{llllllllllllll}377924 & 0.00 & 0.00 & 7.88 & 7.09 & 6.79 & 9.97 & 9.47 & 8.14 & 5.32 & 5.78 & 6.80 & 6.73\end{array}$ $\begin{array}{lllllllllllll}378369 & 0.00 & 7.29 & 7.94 & 7.62 & 7.19 & 0.00 & 10.85 & 8.43 & 0.00 & 6.47 & 6.96 & 7.34 \\ 377874 & 0.00 & 0.00 & 0.00 & 6.54 & 6.46 & 10.68 & 9.41 & 8.24 & 0.00 & 0.00 & 0.00 & 0.00\end{array}$ $\begin{array}{lllllllllllll}377874 & 0.00 & 0.00 & 0.00 & 6.54 & 6.46 & 10.68 & 9.41 & 8.24 & 0.00 & 0.00 & 0.00 & 0.00 \\ 3 & 0.00 & 0.00 & 0.00 & 0.00 & 0.00 & 0.00 & 0.00 & 0.00 & 0.00 & 0.00 & 0.00 & 0.00\end{array}$ $\begin{array}{lllllllllllll}378433 & 0.00 & 0.00 & 0.00 & 0.00 & 0.00 & 0.00 & 0.00 & 0.00 & 0.00 & 0.00 & 0.00 & 0.00\end{array}$ $\begin{array}{lllllllllllll}378433 & 0.00 & 0.00 & 0.00 & 0.00 & 0.00 & 0.00 & 0.00 & 0.00 & 0.00 & 0.00 & 0.00 & 0.00 \\ 378487 & 0.00 & 0.00 & 0.00 & 0.00 & 0.00 & 0.00 & 0.00 & 0.00 & 0.00 & 0.00 & 0.00 & 0.00\end{array}$ $\begin{array}{lllllllllllll}378312-\mathrm{e} & 0.00 & 0.00 & 0.00 & 0.00 & 0.00 & 0.00 & 0.00 & 0.00 & 0.00 & 0.00 & 0.00 & 0.00\end{array}$ $\begin{array}{lllllllllllll}378213-d & 0.00 & 0.00 & 0.00 & 0.00 & 0.00 & 0.00 & 0.00 & 0.00 & 0.00 & 0.00 & 7.54 & 7.02\end{array}$ $\begin{array}{lllllllllllll}377803-12 & 0.00 & 0.00 & 0.00 & 0.00 & 0.00 & 0.00 & 0.00 & 0.00 & 0.00 & 0.00 & 0.00 & 0.00\end{array}$ $\begin{array}{llllllllllllll}377803-14 & 0.00 & 0.00 & 0.00 & 0.00 & 0.00 & 0.00 & 0.00 & 0.00 & 5.20 & 6.19 & 0.00 & 0.00 \\ 377803-16 & 0.00 & 0.00 & 0.00 & 0.00 & 0.00 & 0.00 & 0.00 & 0.00 & 0.00 & 0.00 & 7.01 & 0.00\end{array}$ 


\subsubsection{A população de Lagoa Santa}

Desde meados do século XIX, com os trabalhos de Peter Lund até as intervenções de campo realizadas pelo Projeto Temático "Origens e microevolução do homem na América: uma abordagem paleoantropológica" (Neves et al., 2004 e 2008) a amostra esqueletal da população de Lagoa Santa tem aumentado totalizando, segundo o último trabalho de Neves \& Hubbe (2005), 81 crânios paleoíndios mensuráveis.

Este material está distribuído em, principalmente, 4 coleções distintas, as quais foram acessadas por esta pesquisa. São elas: Coleção do Museu Nacional do Rio de Janeiro (Figura 15), Coleção do Museu de História Natural da UFMG de Minas Gerais (Figura 16 e 17), Coleção do Laboratório de Estudos Evolutivos Humanos - USP São Paulo (Figura 14) - e Coleção do Museu de História Natural da Dinamarca (Figura 18). A coleção dinamarquesa foi inserida neste trabalho devido à oportunidade surgida de viagem de uma pesquisadora do LEEH à Dinamarca para a realização de outra pesquisa. A pesquisadora foi diretamente treinada por mim, objetivando padronização na tomada das medidas. Os espécimes analisados estão listados na Tabela 6.

Tabela 6 - Identificação dos crânios constituintes da amostra esqueletal paleoíndia de Lagoa Santa

\begin{tabular}{|c|c|c|c|}
\hline $\begin{array}{c}\text { Referência } \\
\text { Institucional }\end{array}$ & $\begin{array}{c}\text { Sítio } \\
\text { Arqueológico } \\
\end{array}$ & $\begin{array}{c}\text { Referência } \\
\text { Institucional }\end{array}$ & $\begin{array}{c}\text { Sítio } \\
\text { Arqueológico } \\
\end{array}$ \\
\hline SH-01 & Sumidouro & MN 920 & Lapa Mortuária \\
\hline SH-02 & Sumidouro & MN 1055 & $\mathrm{~S} /$ origem precisa \\
\hline $\mathrm{SH}-04$ & Sumidouro & MN 1055' & $\mathrm{S} /$ origem precisa \\
\hline
\end{tabular}


(Continuação) Tabela 6 - Identificação dos crânios constituintes da amostra esqueletal paleoíndia de Lagoa Santa

\begin{tabular}{|c|c|c|c|}
\hline $\begin{array}{c}\text { Referência } \\
\text { Institucional }\end{array}$ & $\begin{array}{c}\text { Sítio } \\
\text { Arqueológico }\end{array}$ & $\begin{array}{c}\text { Referência } \\
\text { Institucional }\end{array}$ & $\begin{array}{c}\text { Sítio } \\
\text { Arqueológico }\end{array}$ \\
\hline $\mathrm{SH}-07$ & Sumidouro & MN 1319 & Cerca Grande \\
\hline SH-09 & Sumidouro & MN 1325 & Cerca Grande \\
\hline $\mathrm{SH}-10$ & Sumidouro & MN 1332 & Cerca Grande \\
\hline $\mathrm{SH}-11$ & Sumidouro & MN 1337 & Cerca Grande \\
\hline $\mathrm{SH}-16$ & Sumidouro & MN 1338 & Cerca Grande \\
\hline $\mathrm{SH}-17$ & Sumidouro & MN 1339 & Cerca Grande \\
\hline WN-01 & Sumidouro & MN 1340 & Cerca Grande \\
\hline WN-02 & Sumidouro & MN 1341 & Cerca Grande \\
\hline WN-06 & Sumidouro & MN 1342 & Cerca Grande \\
\hline WN-07 & Sumidouro & MN 1349 & Cerca Grande \\
\hline WN-14 & Sumidouro & MN 1352 & Cerca Grande \\
\hline WN-15 & Sumidouro & MN 1363 & Cerca Grande \\
\hline 2186 & Sumidouro & MN 1373 & Cerca Grande \\
\hline 2187 & Sumidouro & MN 1379 & Cerca Grande \\
\hline 2188 & Sumidouro & MN 1383 & Cerca Grande \\
\hline 2194 & Sumidouro & MN 1959 & Lapa Vermelha IV \\
\hline 2199 & Sumidouro & LST sep II & Lapa do Santo \\
\hline M8 & Sumidouro & LST sep III & Lapa do Santo \\
\hline SN & Sumidouro & LST sep IV & Lapa do Santo \\
\hline SN & Sumidouro & LST sep V & Lapa do Santo \\
\hline MN 114 & $\mathrm{~S} /$ origem precisa & LST sep VII & Lapa do Santo \\
\hline MN 630 & Lapa de Carrancas & LST $\operatorname{sep} X$ & Lapa do Santo \\
\hline MN 804 & Lapa do Caetano & LST sep XI & Lapa do Santo \\
\hline MN 805 & Lapa Mortuária & LST sep XV & Lapa do Santo \\
\hline MN 807 & Lapa Mortuária & LST sep XXI & Lapa do Santo \\
\hline MN 810 & Lapa Mortuária & LST sep XXII & Lapa do Santo \\
\hline MN 813 & Lapa da Amoreira & HW - 01 & Harold Walter \\
\hline MN 815 & Lapa da Amoreira & $\mathrm{HW}-05$ & Harold Walter \\
\hline MN 819 & Lapa Mortuária & $\mathrm{HW}-10$ & Harold Walter \\
\hline MN 825 & Lapa Mortuária & HW - 12 & Harold Walter \\
\hline MN 826 & Lapa do Caetano & HW - 55 & Harold Walter \\
\hline MN 827 & Lapa Mortuária & HW - 56 & Harold Walter \\
\hline MN 828 & Lapa do Caetano & HW - 57 & Harold Walter \\
\hline MN 830 & Lapa Mortuária & $H W-60$ & Harold Walter \\
\hline MN 831 & Fazenda do mocambo & $H W-82$ & Harold Walter \\
\hline MN 878 & Lapa do Caetano & HW - 119 & Harold Walter \\
\hline MN 880-1 & $\mathrm{S} /$ origem precisa & HW - 123 & Harold Walter \\
\hline MN 880-2 & $\mathrm{S} /$ origem precisa & HW - 126 & Harold Walter \\
\hline MN 880-3 & $\mathrm{S} /$ origem precisa & HW - 135 & Harold Walter \\
\hline
\end{tabular}


(Continuação) Tabela 6 - Identificação dos crânios constituintes da amostra esqueletal paleoíndia de Lagoa Santa

\begin{tabular}{|c|c|c|c|}
\hline $\begin{array}{c}\text { Referência } \\
\text { Institucional }\end{array}$ & $\begin{array}{c}\text { Sítio } \\
\text { Arqueológico } \\
\end{array}$ & $\begin{array}{c}\text { Referência } \\
\text { Institucional }\end{array}$ & $\begin{array}{c}\text { Sítio } \\
\text { Arqueológico } \\
\end{array}$ \\
\hline MN 880-4 & S/ origem precisa & HW - 137 & Harold Walter \\
\hline MN 880-5 & $\mathrm{S} /$ origem precisa & HW - 139 & Harold Walter \\
\hline MN 880-6 & $\mathrm{S} /$ origem precisa & HW - 291 & Harold Walter \\
\hline MN 880-7 & $\mathrm{S} /$ origem precisa & HW - 292 & Harold Walter \\
\hline MN 881-a & Lapa Mortuária & HW - 295 & Harold Walter \\
\hline MN 881-b & Lapa Mortuária & HW - 2493 & Harold Walter \\
\hline MN 881-c & Lapa Mortuária & HW - 2494 & Harold Walter \\
\hline MN 881-d & Lapa Mortuária & $H W-2495$ & Harold Walter \\
\hline MN 881-h & Lapa Mortuária & HW - 2498 & Harold Walter \\
\hline MN 881-j & Lapa Mortuária & HW - 2503 & Harold Walter \\
\hline MN 882 & Lapa Mortuária & $H W-2506$ & Harold Walter \\
\hline MN $882^{\prime}$ & Lapa Mortuária & HW - 2507 & Harold Walter \\
\hline MN 882-3 & Lapa Mortuária & $H W-2640$ & Harold Walter \\
\hline MN 882-b & Lapa Mortuária & SR 1 - SEP I & Santana do Riacho \\
\hline MN 883 & Lapa Mortuária & SR 1 - SEP IV & Santana do Riacho \\
\hline MN 887 & Lapa Mortuária & SR 1- SEP Va & Santana do Riacho \\
\hline MN 888 & Lapa Mortuária & SR 1 - SEP $X$ & Santana do Riacho \\
\hline MN 888' & Lapa Mortuária & SR 1 - SEP XIXb & Santana do Riacho \\
\hline MN 893 & Fazenda do mocambo & SR 1- SEP XXII & Santana do Riacho \\
\hline
\end{tabular}
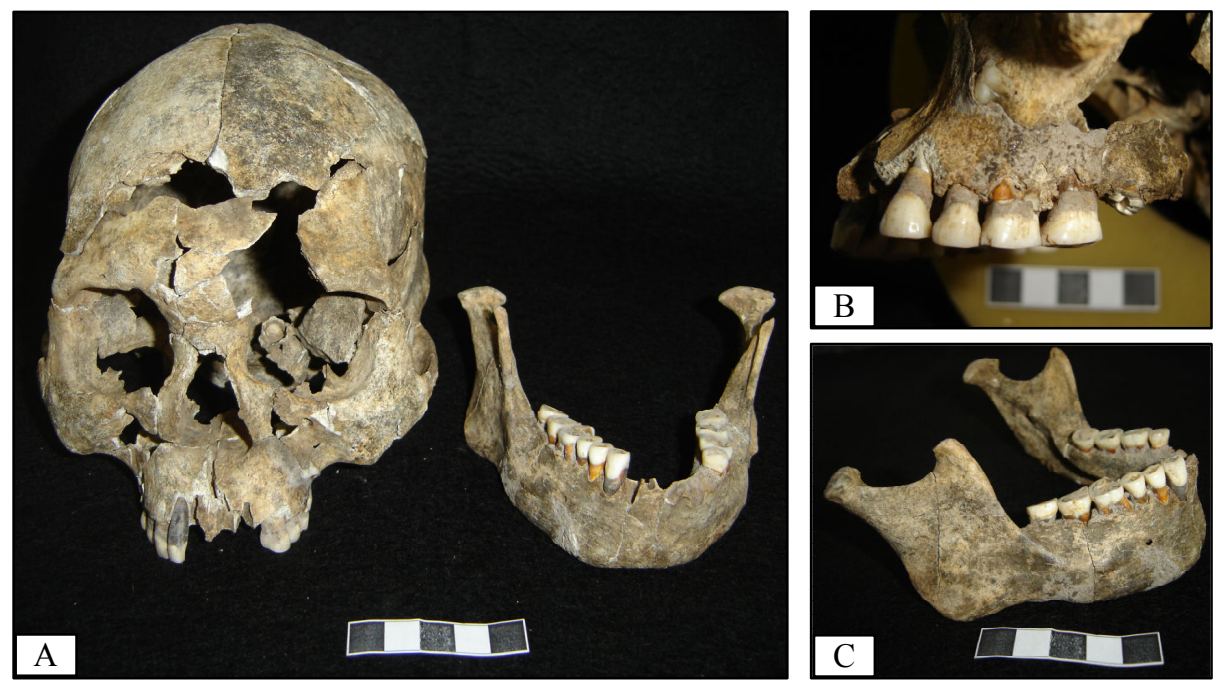

Figura 14 - Exemplar analisado proveniente do Sítio Lapa do Santo, Sepultamento XXII, depositado no Laboratório de Estudos Evolutivos Humanos - USP (A: crânio e mandíbula, ambos em vista frontal; $\mathrm{B}$ : destaque para a face bucal dos dentes maxilares do lado esquerdo; e C: destaque para a mandíbula, vista lateral direita). 

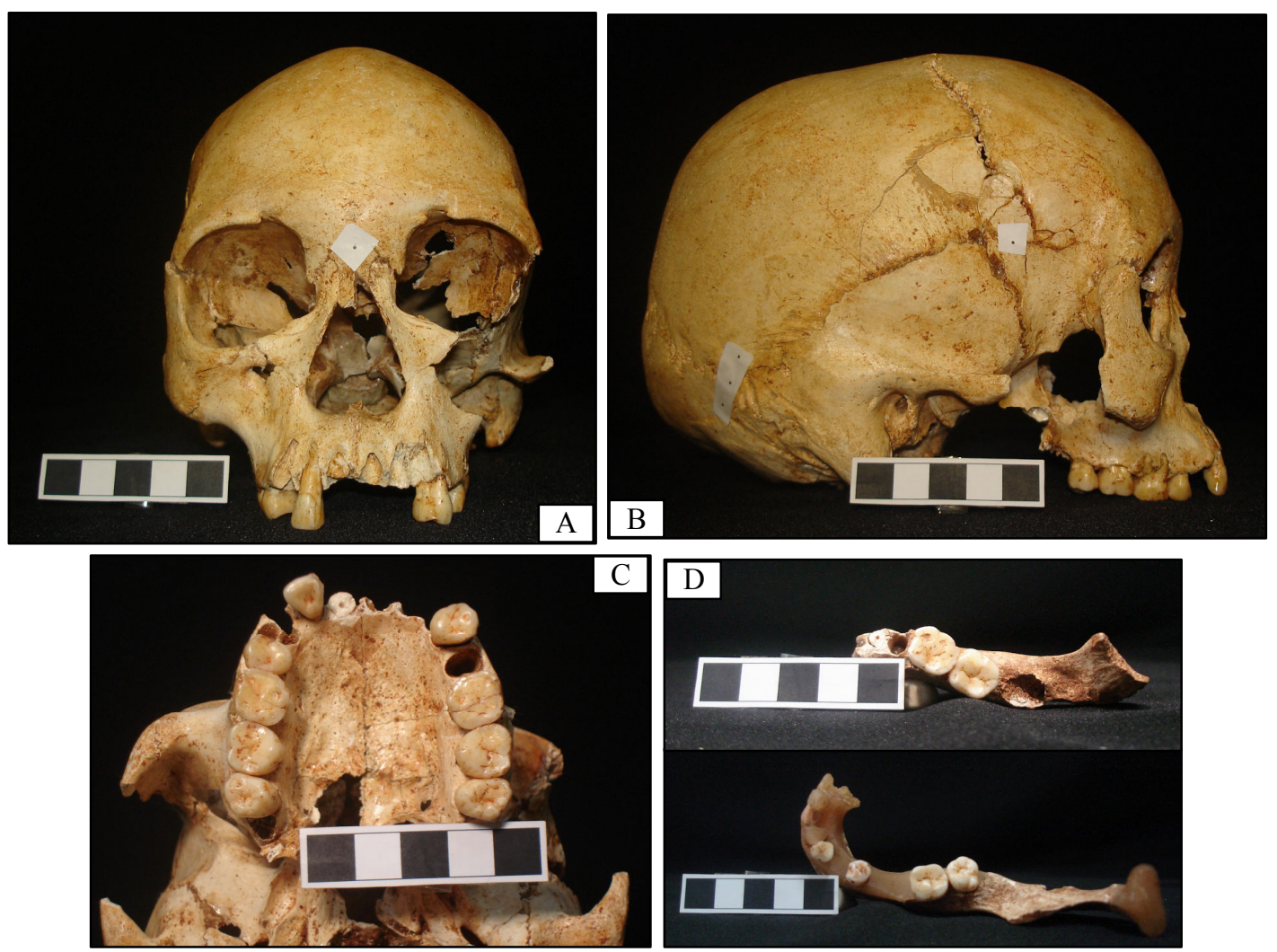

Figura 15 - Exemplar analisado proveniente do Sítio Lapa Vermelha IV popularmente conhecido como Luzia depositado na coleção do Museu Nacional - UFRJ (A: crânio, vista frontal; B: crânio, vista lateral direita; C: destaque para os dentes maxilares, vista oclusal; D: destaque para a mandíbula lado direito e lado esquerdo, vista oclusal).
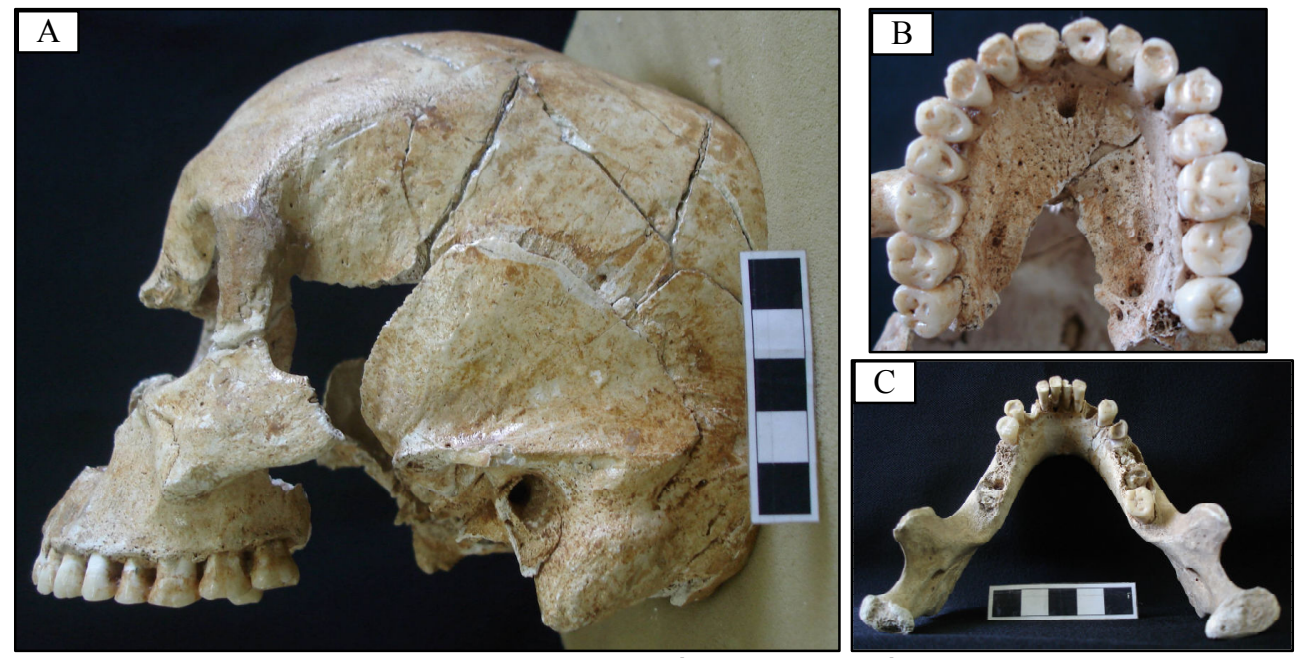

Figura 16 - Exemplar analisado proveniente do Sítio Lapa Mortuária de Confins, popularmente conhecido como Homem de Confins, depositado na coleção Harold Walter do Museu de História Natural - UFMG (A: crânio, vista lateral esquerda; B: destaque para os dentes maxilares, vista oclusal; e C: destaque para a mandíbula, vista oclusal). 

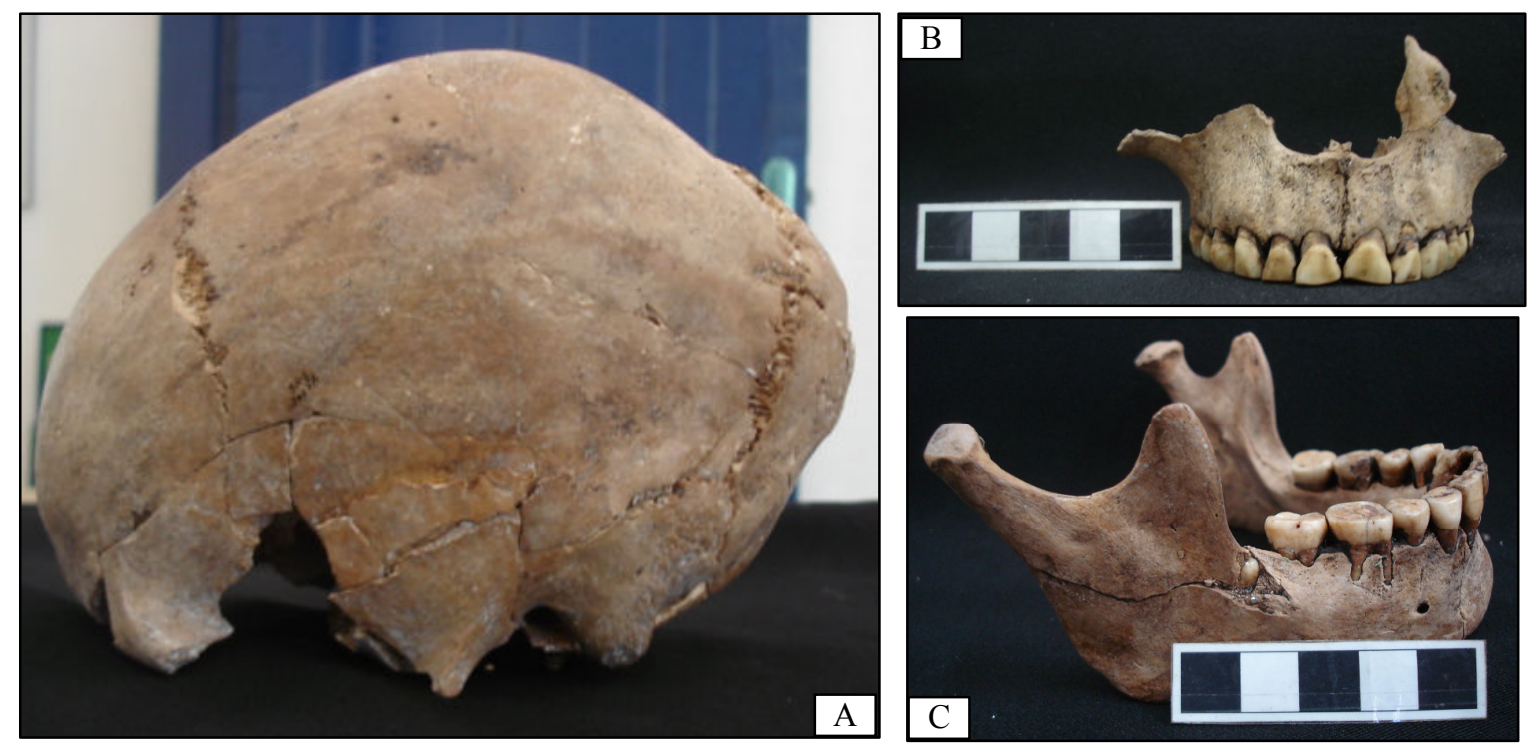

Figura 17 - Exemplar analisado proveniente do sítio Santana do Riacho, Sepultamento Va, depositado na coleção Santana do Riacho do Museu de História Natural da - UFMG (A: crânio, vista lateral esquerda; B: destaque para os dentes maxilares, vista frontal; e C: destaque para a mandíbula, vista lateral direita).
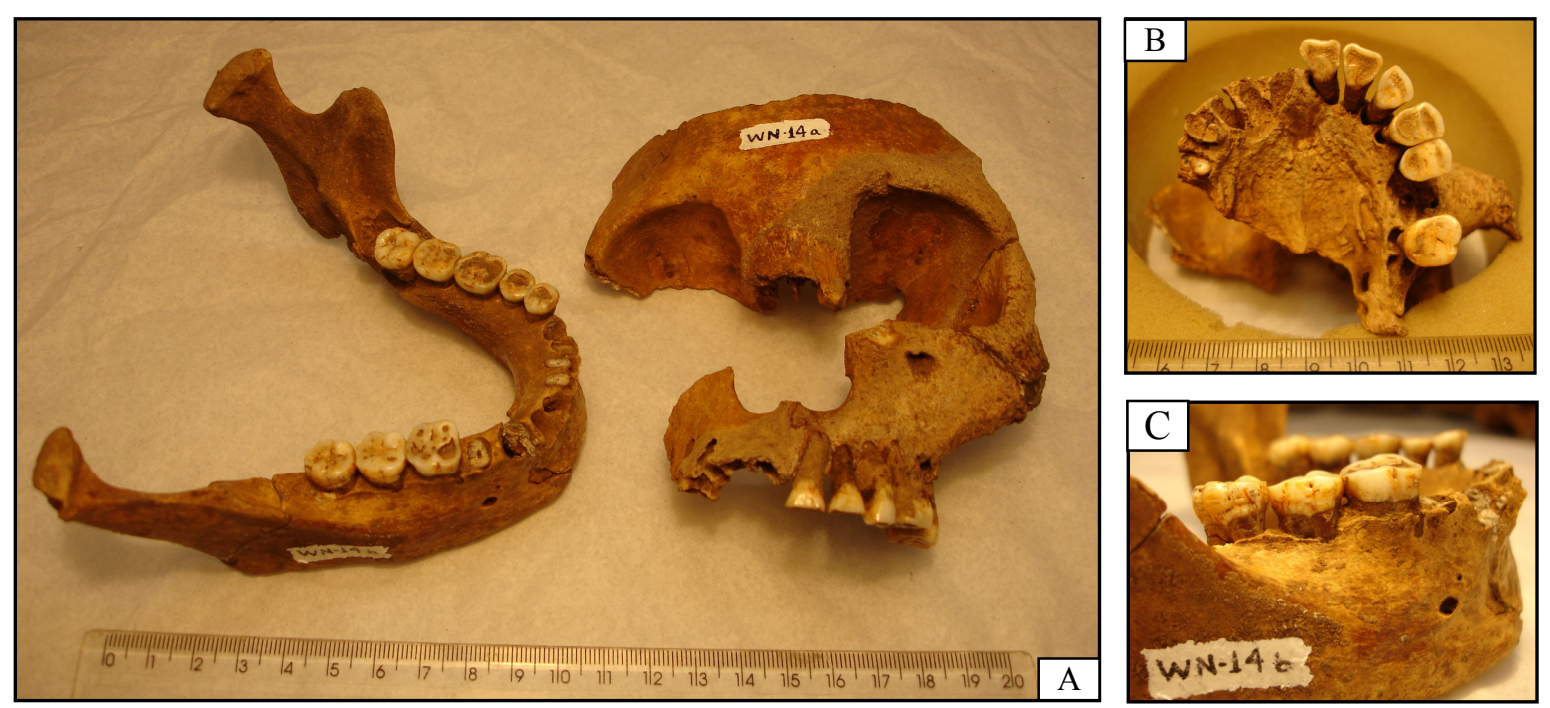

Figura 18 - Exemplar analisado proveniente da Gruta do Sumidouro depositado na coleção do Museu de História Natural de Copenhaguem (A: face, vista frontal e mandíbula, vista oclusal; B: destaque para os dentes maxilares, vista oclusal e C: destaque para a mandíbula, vista lateral direita). 


\subsubsection{Amostra do Museu de Anatomia Humana Professor Alfonso Bovero}

De todo o acervo existente no Museu de Anatomia Humana Professor Alfonso Bovero da Universidade de São Paulo, somente a parcela com origem asiática, mais precisamente os nascidos no Japão, foi analisada (Tabela 7 e Figuras 19 e 20).

As primeiras migrações japonesas a chegarem no Brasil datam de 1908 até 1922 no Porto de Santos (Nogueira, 1973). E são esses primieros imigrantes que constituem a amostra do MAHPAB. Estima-se que esta amostra seja tipicamente mongolóide pela suposta ausência de mistura inter-etnica, já que todos os indivíduos incluídos nesta sub-amostra, teriam nascido no Japão de acordo com registro do tombo e que somente um nascimento é posterior à data das primeiras migrações (indivíduo masculino de 19 anos nascido em 1911) (Registro de Tombo do MAHPAB).

Também nesta amostra é possível observar uma disparidade entre as parcelas masculinas e femininas, sendo mais uma vez a parcela masculina muito maior e muito mais representativa do que a feminina (Figura 19 e 20, repectivamente). Consequentemente, as suposições mais promissoras serão realizadas com base na parcela masculina dos dados. Os procedimentos realizados com a parcela masculina não puderam ser realizados com a parcela feminina, isso 
porque nenhum das mulheres analisadas possui os terceiros molares, inviabilizando assim as análises de serem realizadas.

Tabela 7 - Descrição da amostra coletada no Museu de Anatomia Humana - USP

\begin{tabular}{|c|c|c|c|c|c|c|}
\hline Código Crânio & Código Tombo & Sexo & Idade & Nacionalidade & Ano de Nascimento & Ano da Morte \\
\hline 6 & 10 & $\mathrm{~F}$ & 22 & JAPÃO & 1893 & 1915 \\
\hline 10 & 19 & $\mathrm{~F}$ & 22 & JAPÃO & 1893 & 1915 \\
\hline 15 & 31 & $\mathrm{~F}$ & 35 & JAPÃO & 1881 & 1916 \\
\hline 30 & 58 & $\mathrm{~F}$ & 38 & JAPÃO & 1880 & 1918 \\
\hline 5 & 9 & M & 40 & JAPÃO & 1874 & 1914 \\
\hline 8 & 17 & M & 21 & JAPÃO & 1894 & 1915 \\
\hline 21 & 45 & M & 38 & JAPÃO & 1879 & 1917 \\
\hline 22 & 47 & M & 20 & JAPÃO & 1897 & 1917 \\
\hline 23 & 48 & M & 24 & JAPÃO & 1893 & 1917 \\
\hline 24 & 49 & M & 48 & JAPÃO & 1869 & 1917 \\
\hline 29 & 57 & M & 23 & JAPÃO & 1895 & 1918 \\
\hline 33 & 63 & M & 20 & JAPÃO & 1899 & 1919 \\
\hline 34 & 64 & M & 27 & JAPÃO & 1892 & 1919 \\
\hline 35 & 65 & M & 40 & JAPÃO & 1879 & 1919 \\
\hline 47 & 83 & M & 30 & JAPÃO & 1891 & 1921 \\
\hline 49 & 85 & M & 25 & JAPÃO & 1896 & 1921 \\
\hline 54 & 93 & M & 25 & JAPÃO & 1896 & 1921 \\
\hline 63 & 102 & M & 37 & JAPÃO & 1889 & 1926 \\
\hline 95 & 137 & M & 19 & JAPÃO & 1911 & 1930 \\
\hline 96 & 139 & M & 29 & JAPÃO & 1901 & 1930 \\
\hline
\end{tabular}
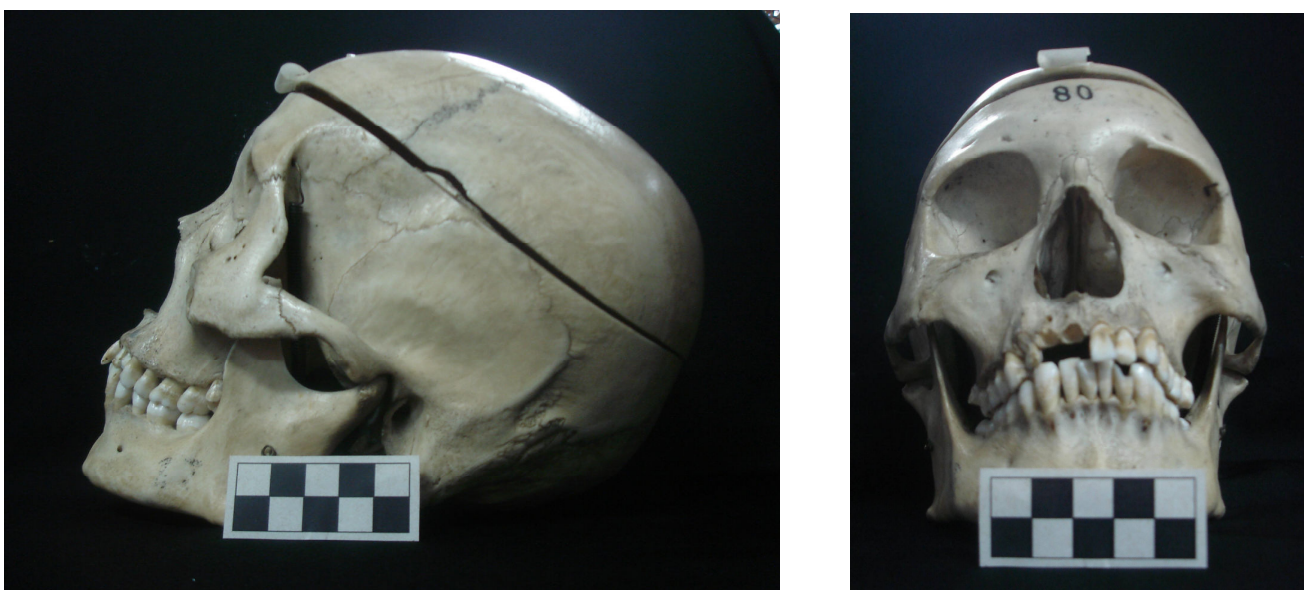

Figura 19 - Indivíduo do sexo masculino em vista lateral esquerda e frontal. 

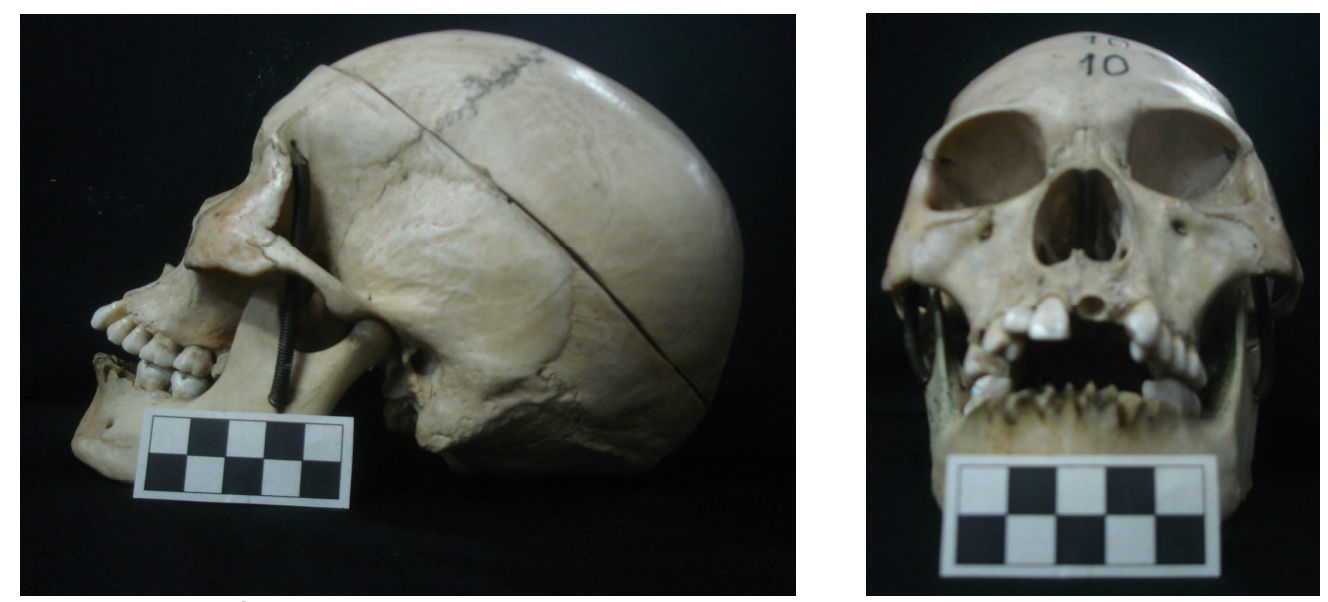

Figura 20 - Indivíduo do sexo feminino em vista lateral esquerda e frontal.

\subsection{Métodos Quantitativos}

\subsubsection{Análises univariadas}

Ao se lidar com bancos de dados, dois tipos de erros são comuns e devem ser controlados pelo pesquisador; ambos dizem respeito à replicabilidade dos dados obtidos, no entanto suas naturezas são diferentes (Wolpoff, 1971; Kieser, 1990; Hilson, 1996; Hair, 2005). O primeiro erro deve-se à precisão das medidas dados coletadas por um único pesquisador (erro intra-observador) e o segundo, por diferenças nas medidas obtidas por pesquisadores diferentes (erro interobservador) (Hair et al., 2005). 


\subsubsection{Erro Intraobservador}

Este tipo de erro é minimizado simplesmente com o treino do executor das medidas e está diretamente relacionado com a experiência do pesquisador e a convergência das anotações realizadas pelo mesmo. Para mensurar este tipo de erro neste trabalho, além de intenso treinamento, medidas foram replicadas no intuito de mensurar a diferença obtida nas duas tomadas de medidas foram aplicados para avaliá-la.

As medidas foram repetidas em duas das coleções, coleção Harold Walter e Santana do Riacho, medidas em sua totalidade em dois momentos espaçados no tempo. Na segunda bateria de medições não houve acesso aos dados anteriormente coletados com as peças acessadas em ordens diferentes. De acordo com a literatura especializada (e.g. Harris \& Smith, 2008), um teste simples como o teste-t pareado é suficiente e recomendado para o diagnótico de diferenças nas medidas replicadas (Hanihara \& Ishida, 2005). Alguns autores sugerem que outros testes sejam realizados, por exemplo o TEM de "Technical Measurement Error", a ANOVA, o desvio-padrão da média, o coeficiente de variação - CV, regressões e análise dos resíduos, bem como correlações de Pearson (para uma revisão ver Harris \& Smith, 2008). Neste trabalho foram empregados testes-t pareados e os coeficentes de correlação de Pearson (r). 


\subsubsection{Erro Interobservador}

O banco de dados global utilizado foi construído por mais de um observador e, portanto a mensuração e/ou o controle dessa diferença precisou ser avaliado. Como nenhuma das coleções medidas pelo Dr. Hanihara pode ser acessada por mim, vias alternativas para tentar controlar eventuais diferenças de medição foram adotadas. Para isso, uma coleção extra foi incluída no estudo, já apresentada anteriormente, os crânios nipônicos do Museu de Anatomia Humana Prof. Alfonso Bovero, de morfologia tipicamente mongolóide. Espera-se que a população extra inserida comporte-se similarmente as populações de japoneses incluídas no banco de dados mundiais, validando, então, indiretamente, a precisão das medidas tomadas. A associação morfológica foi conduzida principalmente nas análises multivaridas.

\subsubsection{Teste de Dimorfisomo Sexual}

Como amplamente relatado na literatura e já mensionado anteriormente, o dimorfismo sexual parece estar presente nos diâmetros dentários humanos. Este dimorfismo sexual, apesar de concensual foi diagnostico de diferentes formas na literatura (Garn et al., 1964; Lewis \& Grainger, 1967; Black III, 1978; Lund, 2001; Kondo et al., 2005; Schwartz \& Dean, 2005; Vodanović et al., 2007; GuatelliSteinberg et al., 2008; Cardoso, 2008). Neste trabalho foram realizados testes de 
Variância Univariada (ANOVA) com o intuito de verificar e quantificar o dimorfismo nas populações humanas aqui estudadas.

A ANOVA é uma técnica de dependência que mede as diferenças para duas variáveis métricas dependentes com base em um conjunto de variáveis categóricas que atuam como variável independente. Ou seja, a ANOVA avalia a diferença média entre grupos. O teste determina a probabilidade de que as diferenças entre médias entre diversos grupos ocorram apenas devido a erro amostral. A ANOVA calcula duas estimativas da variância independente, uma refletindo a variância geral dentro dos grupos e outra representando a diferença entre grupos. A razão entre as duas estimativas é uma medida de quanta variância é atribuível aos diferentes grupos em oposição à variância esperada a partir de amostras aleatórias (Hair et al., 2005).

A hipótese nula da ANOVA é a igualdade de variânicas entre dois grupos para as variáveis em questão. Caso a hipótese nula seja rejeitada, isto é, existe desigualdade média entre os grupos, a ANOVA não é capaz de identificar entre qual(is) conjunto(s) de dado(s) se encontra a diferença estatisticamente significativa. Para isso, são necessários testes a posteriores ou post-hoc. Os testes post-hoc testam a diferença entre todos os possíveis pares de objetos. Não devem ser diretamente aplicados porque seriam necessários diversos testes, o que resultaria em uma somatória de erros (principalmente de rejetiar a hipótese nula quando ela deveria ser aceita), diminuindo assim, sua eficiência e poder (Hair et al., 2005). 


\subsubsection{Análise Exploratória Multivariada}

Apesar de muito interessantes e altamente informativas, as análises univariadas não respondem a questão central deste trabalho, qual seja, as afinidades biológicas da população de Lagoa Santa em âmbito mundial. Essa questão, de acordo com o embasamento teórico apresentado na introdução deste trabalho, é tradicionalmente acessada pela análise simultânea de diversas variáveis em uma ou várias populações. Isso significa que, o importante nas análises de afinidades biológicas é o comportamento do conjunto de variáveis e não o comportamento de uma variável individualmente sobre determinado grupo populacional (Hair et al., 2005).

A técnica escolhida para as análises multivariadas exploratórias foi diminuir a dimensionalidade dos dados, perdendo o menor número de informações originais (variância) possível. Tal abordagem é aplicada amplamente na área da Antropologia Biológica, desde os trabalhos seminais como os de Howells (1973, 1989).

\subsubsection{Análise de Componentes Principais}

As análises de componentes principais foram realizadas de diversas maneiras. Como de praxe na literatura, uma primeira abordagem foi realizada sobre os valores brutos das médias ou centróides de cada população, ou seja, 
baseadas na tendência central de cada população no que diz respeito aos fatores "tamanho" e "forma". De acordo com Brace \& Hunt (1990), dados odontométricos devem ser corrigidos quanto ao fator tamanho pela adaptação do índice C-Score primeiramente sugerido por Howell's (1986). É importante analisar as medidas sem o efeito do tamanho dos indivíduos sobre elas, porque o mesmo poder mascarar a forma. Além disso, o tamanho é diretamente influenciado por condições ambientais imediatas (Corruccini, 1973), efeito que mais uma vez, poderia confundir as afinidades entre duas ou mais populações. As abordagens acima foram realizadas separadamente para as parcelas masculinas e femininas devido ao dimorfismo sexual, (como já mensionado). Portanto, quatro grandes conjuntos de dados foram submetidos a cada teste multivariado empregado: parcela masculina - tamanho e forma, parcela masculina - somente forma, parcela feminina - tamanho e forma e parcela feminina - somente forma.

A capacidade exploratória de um Componente principal está diretamente relacionada à quantidade de informação que cada vetor gerado é capaz de sintetizar a partir de uma matrix de dados com n-variáveis durante a redução da dimensionalidade. Obviamente, quanto maior o valor de cada vetor, maior sua capacidade explanatória (expressa em porcentagem) da variância original. Conseqüentemente, também maior é a resolução das associações/dissociações entre as amostras estudadas (Hair et al., 2005).

Neste trabalho optou-se por extrair os componentes principais a partir de matrizes de covariância, já que ela padroniza a variância original dos dados, 
independente da variância estar multivariávelmente distribuída (Hair et al., 2005). A escolha de trabalhar sobre os centróides populacionais deve-se à natureza do material aqui analisado e do banco de dados escolhido. Primeiramente, na análise com vetores de média não é necessária a substituição dos valores ausentes. Tanto o banco de dados Hanihara quanto os dados por mim coletados apresentam muitos valores ausentes. Além disso, há também dificuldade prática de se analisar e interpretar um gráfco bi ou tridimensional com quase 8.000 indivíduos como é o caso da parcela masculina aqui estudada.

\subsubsection{Substituição de valores ausentes}

A substituição de valores ausentes (ou do inglês "missing-value") é uma realidade na análise de material arqueológico e um tratamento adequado a esses valores torna-se absolutamente necessário. No processo de substituição dos dados diversos fatores devem ser levados em conta, principalmente a quantitade de valores a serem substituídos. O impacto da substituição desses valores pode tanto mascarar padrões subjacentes aos dados originais, quanto criar padrões artificiais. Uma alternativa à substituição dos valores ausentes é a exclusão direta de variáveis e de casos. Dada a natureza do material analisado neste trabalho isto não pôde ser aplicado. Optou-se, preferencialmente, pela análise dos centróides das populações (não necessitando assim substituição de valores ausentes). 
Entretanto, quando necessárias as substituições, o critério adotado substituição por regressão multivariada.

A substituição por regressão é realizada por meio da previsão de uma variável com base em sua relação com outras variáveis no conjunto de dados do indivíduo em pauta. A desvantagem deste método é o reforço das relações já presente nos dados, uma subestimação da variância da amostra e o pressuposto de correlação substancial entre a variável substituída e as demais variáveis. Se as correlações não forem suficientes para a produção de uma boa estimativa, então métodos como a substituição pela média podem ser mais adequados. No entanto, o método de substituição por regressão é promissor e será adotado neste trabalho devido à dispersão aleatória dos valores ausentes na amostra e à alta correlação entre as variáveis.

\subsubsection{Análise de Cluster}

A Análise de Clusters designa uma série de procedimentos estatísticos sofisticados que podem ser utilizados para classificar objetos e pessoas sem préconceitos, ou seja, observando apenas as semelhanças sem pré-definir critérios de inclusão em qualquer agrupamento (Reis, 2001).

É uma técnica analítica de agrupamento com o objetivo de gerar subgrupos significativos de indivíduos. Em outras palavras, classificar os objetos ou indivíduos em um pequeno número de grupos mutuamente excludentes, baseados em 
similaridades. Nesta técnica, diferentemente da Análise Discriminante, os grupos não são pré-definidos (Hair et al., 2005). O resultado final deve ser tal que os indivíduos de um grupo serão mais semelhantes entre si do que em relação a qualquer outro indíviduo não pertencente ao grupo em questão, ou seja, a diferença intragrupo é menor do que a intergrupo. Este método é por principio exploratório e seu objetivo principal é gerar hipóteses mais do que testá-las.

Análises de Cluster foram aqui realizadas tanto sobre componentes principais quanto sobre matrizes de distâncias (Euclidianas e Mahalanobis). Para que o agrupamento fornecido pela análise seja então testado, é necessária a validação dos resultados através da aplicação de outros métodos estatísticos (Índice Cofenético - obtido com o pacote estatístico NTSYS). A definição dos grupos pode ser gerada por uma série de critérios de agregação - ligação pela média não-ponderada (UPGMA), ligação pela média ponderada (WPGMA), ligação completa (complete linkage) e ligação simples (single linkage) e o método de Ward. O método de Ward apesar de não poder ser validado pelo índice cofenético foi inserido na análise devido à sua capacidade explanatória de gerar sub-grupos a qualquer custo.

A "ligação simples" utiliza a distância mínima, ou seja, a semelhança máxima entre dois grupos; em outras palavras, a distância entre dois grupos quaisquer deve ser menor do que a distância de um destes com qualquer outro grupo. A "ligação completa" diferencia-se da "simples" por utilizar a distância máxima entre dois grupos ao invés da semelhança máxima. A "ligação pela média 
não ponderada" avalia a distância entre dois grupos pela média da distância par a par das subunidades analisadas de cada grupo. A "ligação pela média ponderada" diferencia-se desta última pela ponderação dos grupos de acordo com seus tamanhos amostrais, ou seja, dá pesos diferentes a grupos com tamanhos amostrais diferentes.

O Índice Cofenético nada mais é do que uma correlação entre a matriz utilizada para gerar o dendrograma e a matriz produzida pelo agrupamento ou matriz cofenética. Para que o agrupamento seja uma boa solução para as relações existentes entre os grupos analisados, a correlação deve apresentar um alto valor (valores $<0,7$ são muito pobres, $<0,8$ pobres, $<0,9$ bons e valores $>0,9$ muito bons) (NTSYS Help ver 2.02f).

\subsubsection{Análise de Distâncias Biológicas}

Distâncias são produzidas a partir de matrizes de dissimilaridades. A dissimilaridade entre objetos é uma medida de correspondência ou semelhança entre objetos a serem agrupados. Características são combinadas em uma medida de dissimilaridade calculada para todos os pares de objetos. Deste modo, qualquer objeto pode ser comparado a qualquer outro objeto por meio da medida de dissimilaridade.

Diferentes medidas de distâncias podem produzir diferentes agrupamentos. Por isto, utilizarei diferentes métodos de estimação tanto para as distâncias quanto 
para os agrupamentos. As distâncias aplicadas neste estudo foram a Distância Euclidina e a de Mahalanobis também conhecida como $\mathrm{D}^{2}$. A visualização das matrizes de distâncias euclidianas foram obtidas através dos dendrogramas e as matrizes de distâncias de Mahalanobis através de Escalonamento Multidimensional (apresentado mais adiante).

A Distância Euclidiana é a medida mais comumente empregada para mensurar a dissimilaridade entre objetos. Essencialmente é uma medida do comprimento de um segmento de reta entre dois objetos ou pontos (sob uma ótica geométrica, a distância euclidiana entre dois pontos é a hipotenusa de um triângulo retângulo formado por eles) (Hair et al., 2005).

Já a Distância de Mahalanobis é uma forma padronizada da Euclidiana. A resposta é dada em termos de escalonamentos de desvios-padrões que padronizam os dados, com ajustes feitos para intercorrelações entre as variáveis. E esta é uma das vantagens do uso da Distância de Mahalanobis, já que a padronização já está incorporada em seu procedimento (Hair et al., 2005).

\subsubsection{Análise de Escalonamento Multidimensional}

O objetivo principal deste tipo de análise é tornar possível a observação de distâncias em um espaço multidimensional. O resultado são mapas perceptuais com a posição relativa dos objetos (Hair et al., 2005). Tal posição é definida pela distância entre pares de objetos em relação aos outros objetos da análise, 
mantendo os mais semelhantes mais próximos entre si do que de qualquer outro objeto. Análises adicionais são necessárias para descrever ou avaliar quais são os atributos que ditam a posição de cada objeto. O Escalonamento Multidimensional foi aplicado sobre as matrizes de distâncias de Mahalanobis.

De forma esquemática temos então na Figura 21 a série de procedimentos analíticos adotados neste trabalho.

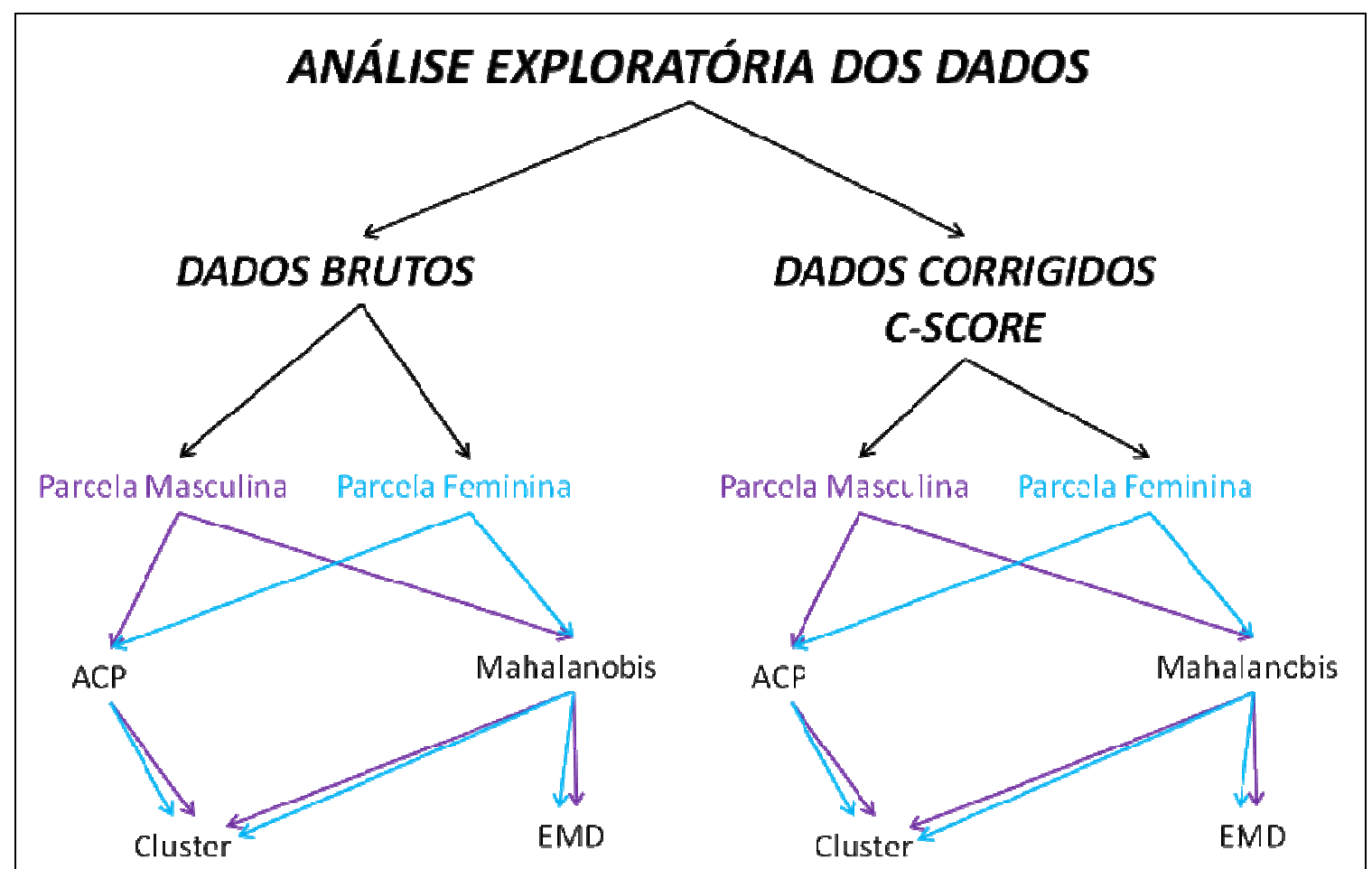

Figura 21 - Diagramação esquemáticas da sucessão de análises estatísticas que foram realizadas neste trabalho. 


\section{Resultados}

Conforme já explicitado anteriormente, os resultados aqui apresentados têm carárer exploratório, destacando-se apenas tendências que necessitarão confirmações posteriores. Todos os gráficos apresentados a seguir seguirão a legenda da Tabela 8 , de acordo com os símbolos disponíveis no programa utilizado - Statiscica 7.0. Os resultados serão apresentados separadamente para a parcela masculina e feminina do banco de dados devido ao dimorfismo sexual (como já discutido).

\begin{tabular}{|c|c|c|c|}
\hline Símbolo & Região & Símbolo & Região \\
\hline 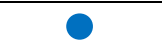 & Arctic & $\Delta$ & N América \\
\hline$\Delta$ & Australia & $\mathbf{0}$ & NE Ásia \\
\hline 0 & C/S America & 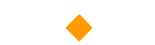 & Polinésia \\
\hline 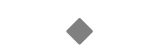 & E Asia & $\square$ & Lagoa Santa \\
\hline$\diamond$ & Europe & * & S Ásia \\
\hline$\Delta$ & Melanesia & $\diamond$ & SE Ásia \\
\hline+ & Micronesia & $\diamond$ & SS África \\
\hline$\Delta$ & A Africa & $\Delta$ & W Ásia \\
\hline
\end{tabular}

\subsection{Análises Univariadas}

\subsubsection{Teste de erro intra-observador}

As medidas repetidas na sub-amostra de Lagoa Santa (coleções Santa do Riacho e Harold Walter) foram submetidas a testes formais de validação. A Tabela 9 apresenta os resultados por variável tanto do teste-t pareado (específico para 
medidas repetidas) quanto para a correlação de Pearson. É possível observar na Tablea 9 que nenhum dos valores do teste-t apresentou valor significativo (ou seja, a hipótese nula de igualdade dos dois grupos não foi negada) e os valores da correlação de Pearson são todos extremamente altos $(r>0,85)$, validando assim a replicabilidade das medidas realizadas por mim.

Tabela 9 - Resultados dos testes-t pareados e das correlações de Pearson.

\begin{tabular}{lcc}
\hline Variável & Teste-t pareado & Correlação de Pearson (r) \\
\hline \hline MD I1 U & 0,9 & 0,94 \\
MD I2 U & 0.860 & 0,962 \\
MD C U & 0,42 & 0,895 \\
MD PM1 U & 0,08 & 0,953 \\
MD PM2 U & 0,47 & 0,921 \\
MD M1 U & 0,66 & 0,845 \\
MD M2 U & 0,34 & 0,981 \\
MD M3 U & 0,31 & 0,979 \\
MD I1 L & 0,16 & 0,986 \\
MD I2 L & 0,83 & 0,998 \\
MD C L & 0,62 & 0,989 \\
MD PM1 L & 0,32 & 0,933 \\
MD PM2 L & 0,59 & 0,868 \\
MD M1 L & 0,85 & 0,879 \\
MD M2 L & 0,97 & 0,952 \\
MD M3 L & 0,49 & 0,994 \\
BL I1 U & 0,18 & 0,85 \\
BL I2 U & 0,41 & 0,875 \\
BL C U & 0,83 & 0,893 \\
BL PM1 U & 0,26 & 0,995 \\
BL PM2 U & 0,34 & 0,977 \\
BL M1 U & 0,25 & 0,863 \\
BL M2 U & 0,14 & 0,991 \\
BL M3 U & 0,98 & 0,994 \\
BL I1 L & 0,34 & 0,979 \\
BL I2 L & 0,19 & 0,996 \\
BL C L & 0,13 & 0,924 \\
BL PM1 L & 0,13 & 0,862 \\
BL PM2 L & 0,09 & 0,979 \\
BL M1 L & 0,86 & 0,894 \\
BL M2 L & 0,38 & 0,891 \\
BL M3 L & 0,49 & 0,957 \\
\hline
\end{tabular}




\subsubsection{Análise do Dimorfismo sexual}

O dimorfismo sexual das populações envolvidas foi estimado pela Análise de Variância Univarida (ANOVA), já que o intuito do teste era verificar diferenças significativas entre os valores de cada variável individualmente. A Tabela 12 traz os resultados dos testes realizados para o banco de dados completo. Neste banco foram incluídas somente as populações que possuiram indivíduos de ambos os dois sexos. Todas as variáveis apresentaram diferenças significativas entre o sexo masculino e feminino.

Tabela 10 - Resultado das ANOVAs para os testes de dimorfismo sexual.

\begin{tabular}{|c|c|c|c|c|c|}
\hline & & $\begin{array}{c}\text { Soma dos } \\
\text { Quadrados } \\
\end{array}$ & $\begin{array}{l}\text { Quadrados } \\
\text { Médios }\end{array}$ & $\mathbf{F}$ & Sig. \\
\hline \multirow[t]{3}{*}{$M D I 1 U$} & Between Groups & 15,6816 & 15,6816 & 42,0955 & 0,000 \\
\hline & Within Groups & 576,2954 & 0,3725 & & \\
\hline & Total & 591,977 & & & \\
\hline \multirow[t]{3}{*}{$M D I 2 U$} & Between Groups & 8,9175 & 8,9175 & 22,6123 & 0,000 \\
\hline & Within Groups & 750,4809 & 0,3944 & & \\
\hline & Total & 759,3984 & & & \\
\hline \multirow[t]{3}{*}{$M D \subset U$} & Between Groups & 33,1274 & 33,1274 & 120,243 & 0,000 \\
\hline & Within Groups & 763,9727 & 0,2755 & & \\
\hline & Total & 797,1002 & & & \\
\hline \multirow[t]{3}{*}{ MD PM1 U } & Between Groups & 24,8436 & 24,8436 & 94,9047 & 0,000 \\
\hline & Within Groups & 895,2667 & 0,2618 & & \\
\hline & Total & 920,1103 & & & \\
\hline \multirow[t]{3}{*}{ MD PM2 U } & Between Groups & 17,6796 & 17,6796 & 58,4612 & 0,000 \\
\hline & Within Groups & 1037,8931 & 0,3024 & & \\
\hline & Total & 1055,5727 & & & \\
\hline \multirow[t]{3}{*}{$M D M 1 U$} & Between Groups & 72,3078 & 72,3078 & 178,1652 & 0,000 \\
\hline & Within Groups & 1808,4545 & 0,4058 & & \\
\hline & Total & 1880,7624 & & & \\
\hline \multirow[t]{3}{*}{$M D M 2 U$} & Between Groups & 122,3635 & 122,3635 & 211,6543 & 0,000 \\
\hline & Within Groups & 2499,8287 & 0,5781 & & \\
\hline & Total & 2622,1921 & & & \\
\hline
\end{tabular}


(Continuação) Tabela 10 - Resultado das ANOVAs para os testes de dimorfismo sexual.

\begin{tabular}{|c|c|c|c|c|c|}
\hline & & $\begin{array}{l}\text { Soma dos } \\
\text { Quadrados }\end{array}$ & $\begin{array}{c}\text { Quadrados } \\
\text { Médios }\end{array}$ & $\mathbf{F}$ & Sig. \\
\hline \multirow[t]{3}{*}{$M D M 3 U$} & Between Groups & 35,2081 & 35,2081 & 44,3974 & 0,000 \\
\hline & Within Groups & 2100,7109 & 0,793 & & \\
\hline & Total & 2135,9189 & & & \\
\hline \multirow[t]{3}{*}{$M D / 1 L$} & Between Groups & 1,2337 & 1,2337 & 8,6186 & 0,0034 \\
\hline & Within Groups & 205,8379 & 0,1431 & & \\
\hline & Total & 207,0715 & & & \\
\hline \multirow[t]{3}{*}{$M D I 2 L$} & Between Groups & 2,043 & 2,043 & 9,8691 & 0,0017 \\
\hline & Within Groups & 381,7195 & 0,207 & & \\
\hline & Total & 383,7625 & & & \\
\hline \multirow[t]{3}{*}{$M D C L$} & Between Groups & 49,2155 & 49,2155 & 189,8757 & 0,000 \\
\hline & Within Groups & 586,5663 & 0,2592 & & \\
\hline & Total & 635,7818 & & & \\
\hline \multirow[t]{3}{*}{ MD PM1 L } & Between Groups & 26,9657 & 26,9657 & 99,0679 & 0,000 \\
\hline & Within Groups & 763,5038 & 0,2722 & & \\
\hline & Total & 790,4695 & & & \\
\hline \multirow[t]{3}{*}{$M D P M 2 L$} & Between Groups & 22,1149 & 22,1149 & 64,6701 & 0,000 \\
\hline & Within Groups & 970,498 & 0,342 & & \\
\hline & Total & 992,613 & & & \\
\hline \multirow[t]{3}{*}{$M D M 1 L$} & Between Groups & 42,9628 & 42,9628 & 95,8099 & 0,000 \\
\hline & Within Groups & 1515,2027 & 0,4484 & & \\
\hline & Total & 1558,1656 & & & \\
\hline \multirow[t]{3}{*}{$M D M 2 L$} & Between Groups & 86,428 & 86,428 & 122,85 & 0,000 \\
\hline & Within Groups & 2415,2012 & 0,7035 & & \\
\hline & Total & 2501,6292 & & & \\
\hline \multirow[t]{3}{*}{ MD M3 L } & Between Groups & 126,0919 & 126,0919 & 128,9178 & 0,000 \\
\hline & Within Groups & 2561,5917 & 0,9781 & & \\
\hline & Total & 2687,6836 & & & \\
\hline \multirow[t]{3}{*}{$B L I 1 U$} & Between Groups & 10,79 & 10,79 & 40,0636 & 0,000 \\
\hline & Within Groups & 459,4637 & 0,2693 & & \\
\hline & Total & 470,2537 & & & \\
\hline \multirow[t]{3}{*}{$B L I 2 U$} & Between Groups & 11,5116 & 11,5116 & 41,5004 & 0,000 \\
\hline & Within Groups & 556,4368 & 0,2774 & & \\
\hline & Total & 567,9484 & & & \\
\hline \multirow[t]{3}{*}{$B L C U$} & Between Groups & 110,1771 & 110,1771 & 282,6966 & 0,000 \\
\hline & Within Groups & 1087,7533 & 0,3897 & & \\
\hline & Total & 1197,9304 & & & \\
\hline \multirow[t]{3}{*}{ BL PM1 U } & Between Groups & 66,4134 & 66,4134 & 145,6961 & 0,000 \\
\hline & Within Groups & 1542,0909 & 0,4558 & & \\
\hline & Total & 1608,5044 & & & \\
\hline \multirow[t]{3}{*}{$B L P M 2 U$} & Between Groups & 102,1061 & 102,1061 & 209,153 & 0,000 \\
\hline & Within Groups & 1674,487 & 0,4882 & & \\
\hline & Total & 1776,5931 & & & \\
\hline \multirow[t]{3}{*}{$B L M 1 U$} & Between Groups & 116,7391 & 116,7391 & 264,4945 & 0,000 \\
\hline & Within Groups & 1993,2133 & 0,4414 & & \\
\hline & Total & 2109,9525 & & & \\
\hline
\end{tabular}


(Continuação) Tabela 10 - Resultado das ANOVAs para os testes de dimorfismo sexual.

\begin{tabular}{|c|c|c|c|c|c|}
\hline & & $\begin{array}{l}\text { Soma dos } \\
\text { Quadrados }\end{array}$ & $\begin{array}{c}\text { Quadrados } \\
\text { Médios }\end{array}$ & $\mathbf{F}$ & Sig. \\
\hline \multirow[t]{3}{*}{$B L M 2 U$} & Between Groups & 270,8206 & 270,8206 & 387,8847 & 0,000 \\
\hline & Within Groups & 3011,3313 & 0,6982 & & \\
\hline & Total & 3282,1519 & & & \\
\hline \multirow[t]{3}{*}{$B L M 3 U$} & Between Groups & 173,5943 & 173,5943 & 198,6936 & 0,000 \\
\hline & Within Groups & 2213,0275 & 0,8737 & & \\
\hline & Total & 2386,6218 & & & \\
\hline \multirow[t]{3}{*}{$B L I 1 L$} & Between Groups & 6,0021 & 6,0021 & 34,1811 & 0,000 \\
\hline & Within Groups & 268,4883 & 0,1756 & & \\
\hline & Total & 274,4904 & & & \\
\hline \multirow[t]{3}{*}{$B L I 2 L$} & Between Groups & 6,0467 & 6,0467 & 31,1877 & 0,000 \\
\hline & Within Groups & 363,1399 & 0,1939 & & \\
\hline & Total & 369,1866 & & & \\
\hline \multirow[t]{3}{*}{$B L C L$} & Between Groups & 89,6202 & 89,6202 & 258,36 & 0,000 \\
\hline & Within Groups & 780,1355 & 0,3469 & & \\
\hline & Total & 869,7557 & & & \\
\hline \multirow[t]{3}{*}{ BL PM1 L } & Between Groups & 51,1559 & 51,1559 & 131,0815 & 0,000 \\
\hline & Within Groups & 1042,3852 & 0,3903 & & \\
\hline & Total & 1093,5411 & & & \\
\hline \multirow[t]{3}{*}{$B L P M 2 L$} & Between Groups & 41,2404 & 41,2404 & 110,946 & 0,000 \\
\hline & Within Groups & 999,5442 & 0,3717 & & \\
\hline & Total & 1040,7846 & & & \\
\hline \multirow[t]{3}{*}{$B L M 2 L$} & Between Groups & 61,1859 & 61,1859 & 131,3705 & 0,000 \\
\hline & Within Groups & 1519,7439 & 0,4658 & & \\
\hline & Total & 1580,9297 & & & \\
\hline \multirow[t]{3}{*}{$B L M 3 L$} & Between Groups & 66,7517 & 66,7517 & 112,2708 & 0,000 \\
\hline & Within Groups & 1474,5075 & 0,5946 & & \\
\hline & Total & 1541,2592 & & & \\
\hline
\end{tabular}

\subsection{Análises Multivariadas}

A Tabela 11 apresenta os autovalores dos oito primeiros componentes principais gerados para a parcela masculina com base nos dados brutos, ou seja, levando-se em consideração tamanho e forma. Nela é possível observar uma 
grande discrepância em termos de variância explicada entre o Primeiro Componente Principal e os demais (com cerca de $75 \%$ da variância original explicada pelo Primeiro Componente). Este valor destaca a importância do tamanho dos dentes na análise. Os demais componentes principais explicam pouco da variância observada entre as populações utilizadas, com o Segundo Componente explicando apenas cerca de 6,0\%; os demais componentes explicam, cada um, menos de $5 \%$ da variância original. A visualização gráfica do decaimento dos valores de variância explicada por cada componente é também apresentado na Figura 22, na qual uma queda abrupta pode ser observada após o Primeiro Componente.

Tabela 11 - Autovalores e percentuais de variância explicada pelos primeiros oito componentes principais. Parcela masculina, tamanho e forma (73 populações, 32 variáveis).

\begin{tabular}{ccccc}
\hline $\begin{array}{c}\text { Componente } \\
\text { Principal }\end{array}$ & Autovalor & $\begin{array}{c}\text { \% Total de } \\
\text { Variância Explicada }\end{array}$ & $\begin{array}{c}\text { Autovalor } \\
\text { Cumulativo }\end{array}$ & $\begin{array}{c}\% \\
\text { Cumulativa }\end{array}$ \\
\hline \hline 1 & 2,871004 & 75,38518 & 2,871004 & 75,3852 \\
2 & 0,232611 & 6,10778 & 3,103615 & 81,4930 \\
3 & 0,176471 & 4,63368 & 3,280087 & 86,1266 \\
4 & 0,096648 & 2,53774 & 3,376735 & 88,6644 \\
5 & 0,064388 & 1,69066 & 3,441123 & 90,3550 \\
6 & 0,054156 & 1,42200 & 3,495279 & 91,7770 \\
7 & 0,050446 & 1,32457 & 3,545725 & 93,1016 \\
8 & 0,039045 & 1,02522 & 3,584769 & 94,1268 \\
\hline
\end{tabular}

De acordo com a Tabela 12 o Primeiro Componente Principal extraído dos dados brutos, ou seja, tamanho e forma, apresenta-se altamente correlacionado com todas as variáveis, de forma negativa (visualização gráfica na Figura 23). Isto reafirma que o Primeiro Componente é definido essencialmente pelo fator 
"tamanho". Assim, as populações que estão na porção esquerda da Figura 24 são aquelas com os maiores dentes, e vice-versa.

No que diz respeito à correlação das variáveis originais com o Segundo Componente Principal o panorama é totalmente diferente. Somente uma variável original (BLPM1L) apresenta correlação (negativa) maior que 0,5. Entretanto, é possível observar que as variáveis que apresentam as maiores correlações (ainda que baixas no geral) com o Segundo Componente Principal, pertencem sobretudo a um grupo dentário específico, o dos dentes anteriores (incisivos e caninos), com correlações positivas no caso dos diâmetros mesiodistais e negativas no caso dos diâmetros bucolinguais. Isto quer dizer que as populações localizadas nos quadrantes superiores da Figura 24 possuem incisivos mais lateralizados enquanto que as populações dos quadrantes infeirores dentes incisivos mais espessos.

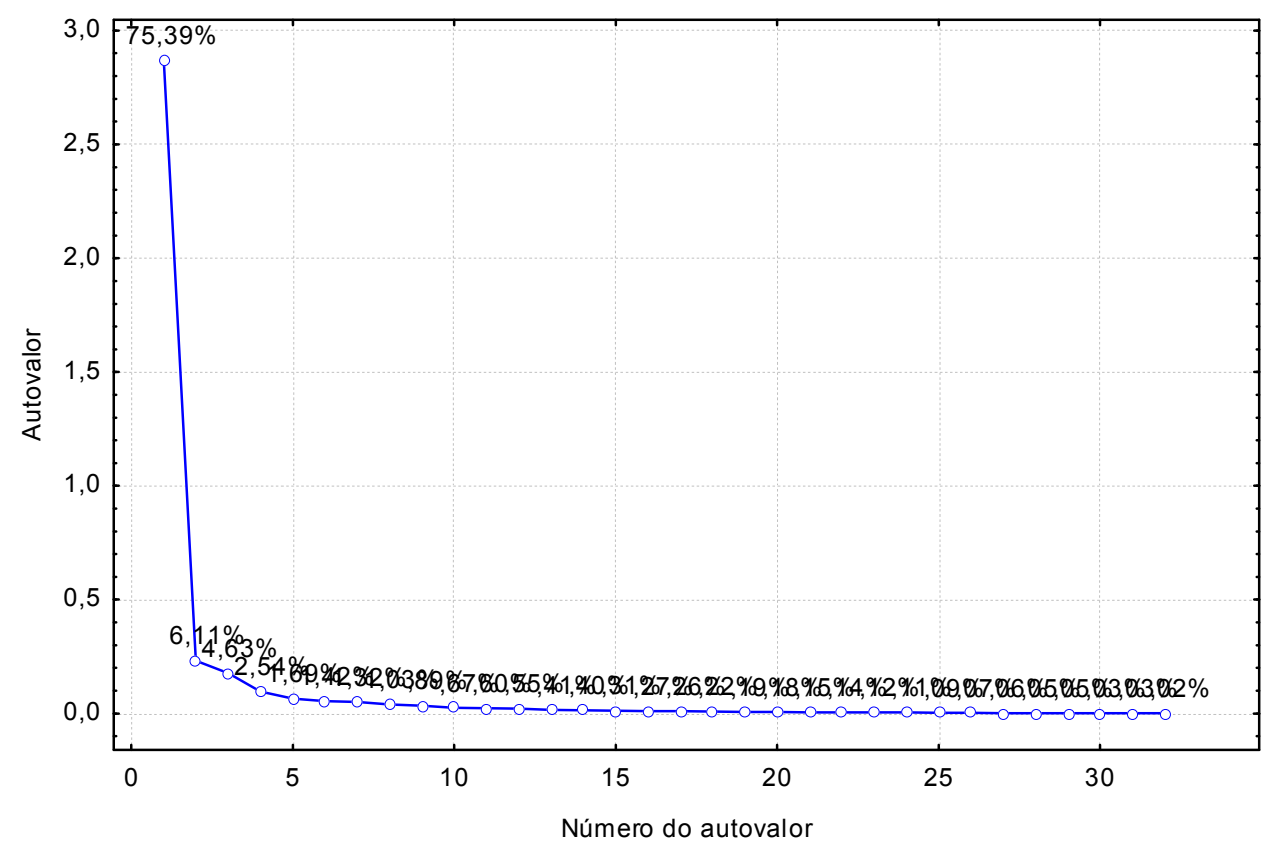

Figura 22 - Screeplot representando o decaimento das porcentagens de variância explicada por cada componente principal. Parcela masculina, tamanho e forma (73 populações, 32 variáveis). 
Tabela 12 - Correlação entre as variáveis originais e os componentes principais extraídos. Parcela masculina, tamanho e forma (73 populações, 32 variáveis).

\begin{tabular}{|c|c|c|}
\hline & Fator 1 & Fator 2 \\
\hline MD I1 U & $-0,7941$ & 0,2759 \\
\hline MD I2 U & $-0,8012$ & 0,4302 \\
\hline MD C U & $-0,8572$ & 0,2764 \\
\hline MD PM1 U & $-0,8726$ & 0,0939 \\
\hline MD PM2 U & $-0,8977$ & 0,1719 \\
\hline MD M1 U & $-0,9021$ & 0,2525 \\
\hline MD M2 U & $-0,9375$ & 0,1403 \\
\hline MD M3 U & $-0,8315$ & 0,0796 \\
\hline MD I1 L & $-0,7843$ & 0,3350 \\
\hline MD I2 L & $-0,8397$ & 0,3571 \\
\hline MD C L & $-0,8697$ & 0,2230 \\
\hline MD PM1 U & $-0,8726$ & 0,0939 \\
\hline MD PM2 U & $-0,8977$ & 0,1719 \\
\hline MD M1 U & $-0,9021$ & 0,2525 \\
\hline MD M2 U & $-0,9375$ & 0,1403 \\
\hline MD M3 U & $-0,8315$ & 0,0796 \\
\hline MD I1 L & $-0,7843$ & 0,3350 \\
\hline MD I2 L & $-0,8397$ & 0,3571 \\
\hline MD C L & $-0,8697$ & 0,2230 \\
\hline MD PM1 L & $-0,8634$ & $-0,1023$ \\
\hline MD PM2 L & $-0,8758$ & $-0,0376$ \\
\hline MD M1 L & $-0,9015$ & 0,2273 \\
\hline MD M2 L & $-0,9451$ & 0,1097 \\
\hline MD M3 L & $-0,8998$ & $-0,0166$ \\
\hline BL I1 U & $-0,8054$ & 0,0635 \\
\hline $\mathrm{BL}$ I2 U & $-0,7518$ & $-0,0369$ \\
\hline$B L C U$ & $-0,8209$ & $-0,2175$ \\
\hline BL PM1 U & $-0,8633$ & $-0,2432$ \\
\hline BL PM2 U & $-0,8803$ & $-0,3485$ \\
\hline BL M1 U & $-0,9405$ & 0,0228 \\
\hline BL M2 U & $-0,9185$ & $-0,2094$ \\
\hline BL M3 U & $-0,7773$ & $-0,4242$ \\
\hline BL I1 L & $-0,5381$ & $-0,4296$ \\
\hline BL I2 L & $-0,5379$ & $-0,4423$ \\
\hline BL C L & $-0,6759$ & $-0,2743$ \\
\hline BL PM1 L & $-0,7834$ & $-0,5198$ \\
\hline BL PM2 L & $-0,8066$ & $-0,4695$ \\
\hline BL M1 L & $\underline{-0,9065}$ & 0,1468 \\
\hline BL M2 L & $\underline{-0,9451}$ & $-0,0022$ \\
\hline BL M3 L & $\underline{-0,9308}$ & $-0,0770$ \\
\hline
\end{tabular}

*destaque em vermelho para correlações maiores que 0,5 , sublinado para as correlações maiores que 0,9 e, em itálico, as correlações mais altas obtidas quando nenhuma das correlações ultrapassa o valor de 0,5 .

A projeção das correlações entre as variáveis originais e os dois primeiros 
componentes principais é apresentada na Figura 23. Destaque deve ser dado ao fato de todas as projeções seguirem uma mesma direção. Em outras palavras, a distribuição das populações no morfo-espaço da Figura 24 deve-se, principalmente, ao tamanho dentário. É possível observar ainda um padrão com três faixas agrupando os diâmetros analisados por tipos dentários (em verde os incisivos na porção direita do gráfico, em laranja os molares na região mais à esquerda, e em azul os pré-molares na porção mais central).

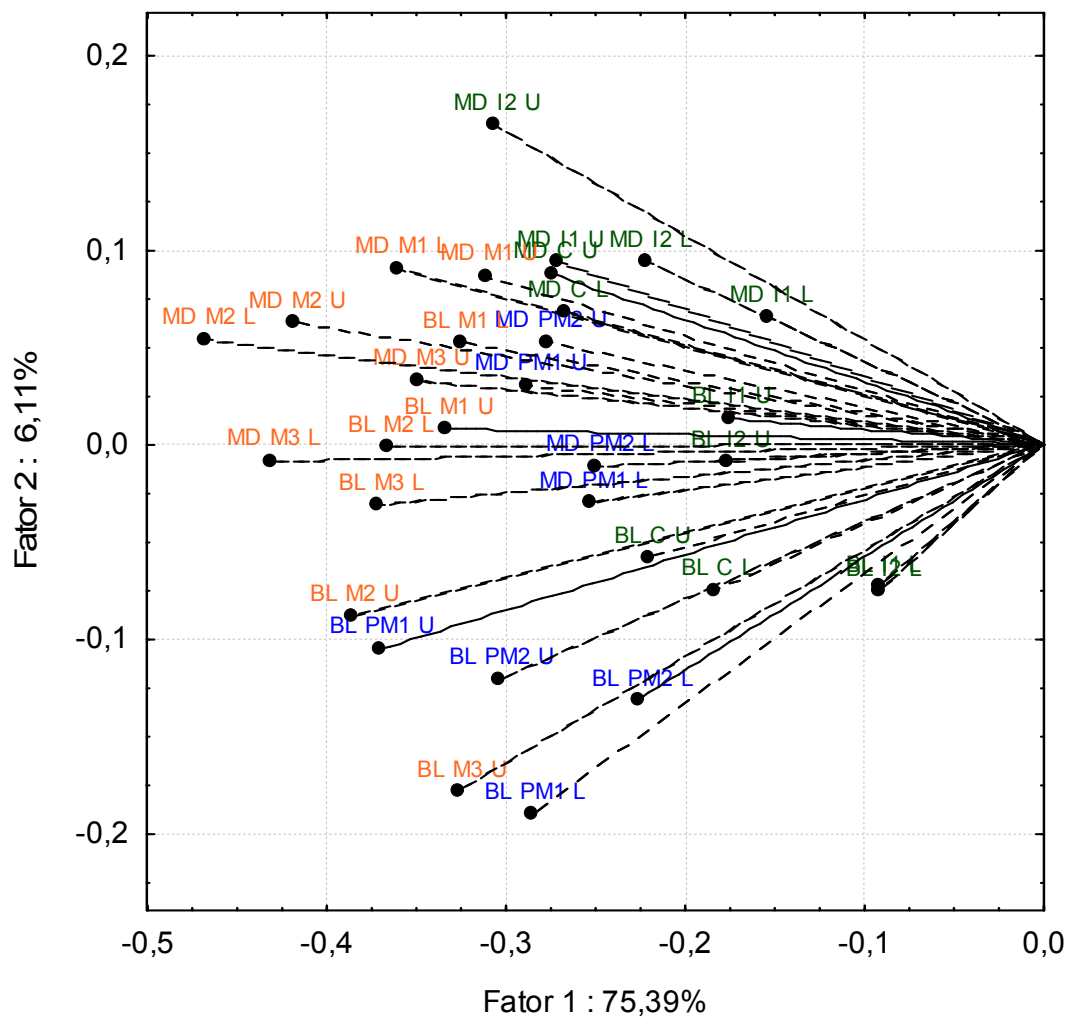

Figura 23 - Projeção das variáveis no morfo-espaço definido pelos dois primeiros Componentes Principais. Parcela masculina, tamanho e forma (73 populações, 32 variáveis).

O gráfico do morfo-espaço formado pelos dois primeiros componentes principais na Figura 24 parece separar três agrupamentos: as populações australo- 
melanésicas, no quadrante inferior esquerdo, caracterizadas principalmente por molares e pré-molares largos; os nativos americanos, no quadrante superior esquerdo, definidos por dentes incisivos e molares largos; e as demais populações, na metade direita, com tamanhos dentários menores. As populações australianas apresentam os maiores dentes entre todas as populações analisadas, seguidas pelas populações melanésicas e africanas, principalmente no que diz respeito aos molares. No entanto, as populações australo-melanésicas e africanas apresentam dentes anteriores mais espessos, enquanto que as populações americanas, também com dentes grandes, possuem dentes anteriores lateralizados. A população de Lagoa Santa (destacada pela seta vermelha) com dentes de tamanho médio e dentes anteriores levemente mais espessos, encontra-se dentro da elipse de dispersão das populações do Sudeste Asiático, extremamente distante das demais populações nativas americanas. A população Japonesa do Museu de Anatomia Humana da USP (destacada pela seta cinza) encontra-se, conforme esperado, dentro da elipse de dispersão das populações do Leste Asiático, muito proximamente associada aos chineses, com dentes de tamanho reduzido.

A quebra abrupta da porcentagem de variância original explicada após o terceiro componente (Figura 22) fez com que as análises de cluster, por meio de matrizes de Distâncias Euclidianas, fossem realizadas com base nos três primeiros CPs apenas. A Tabela 13 apresenta os índices cofenéticos para os diferentes critérios de agregação (ligação simples, composta, ponderada pela média e não ponderada pela média). 


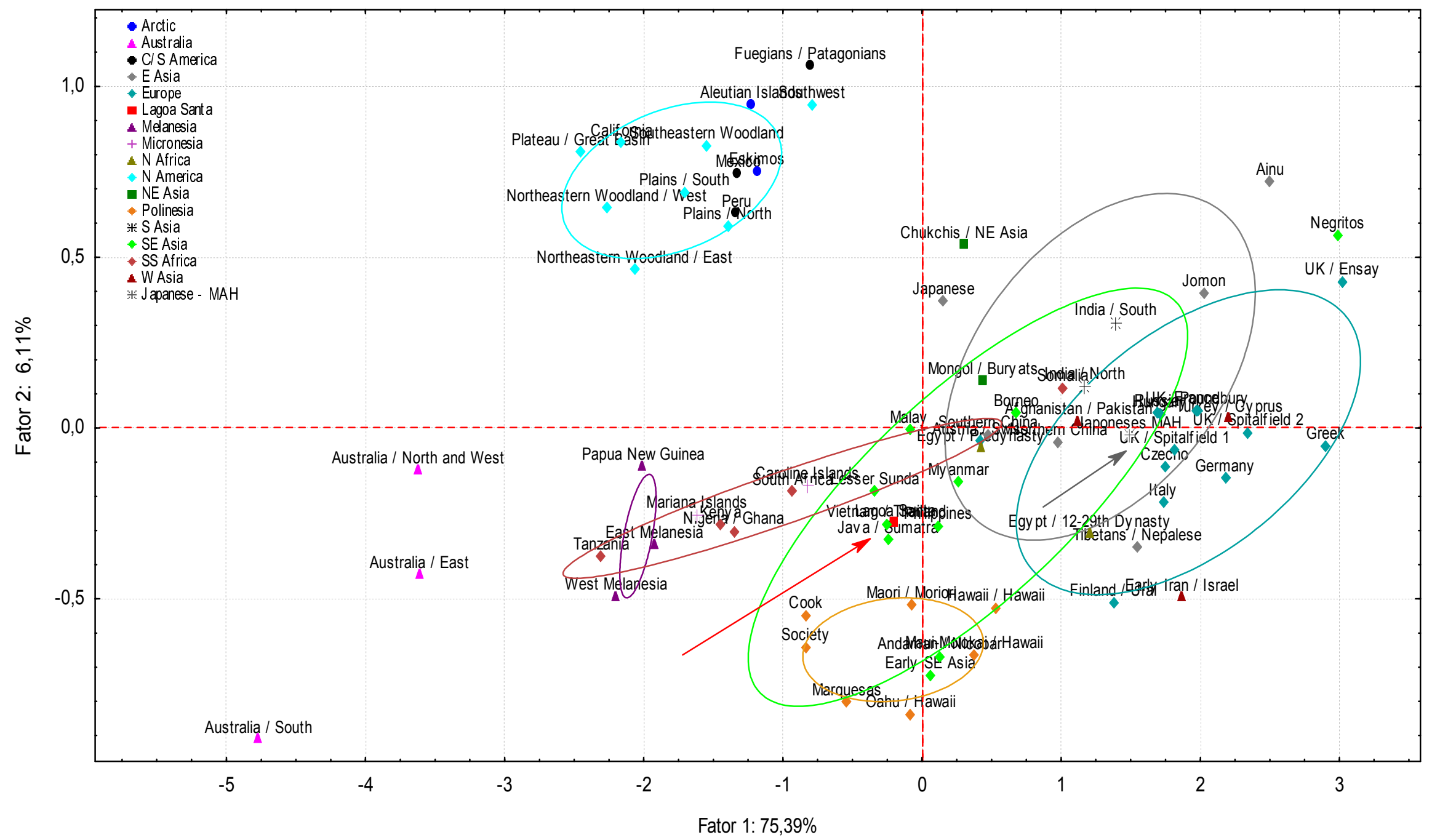

Figura 24 - Morfo-espaço formado pelos $1^{\circ}$ e $2^{\circ}$ componentes principais. Parcela masculina, tamanho e forma (73 populações, 32 variáveis). 
Todos os valores dos Índices Cofenéticos (Tabela 13) estão aquém do necessário para a validação de qualquer um dos métodos aplicados. $\mathrm{O}$ valor recomendado para agrupamentos regulares é de $r=0,70$ (NTSYS Help, VER2.02F). Entretanto, este valor é dificilmente obtido e um relaxamento do critério pode ser adotado. Porém, os valores aqui obtidos (Tabela 13) são todos menores que 0,4 , e portanto, nenhum dendrograma foi gerado.

Tabela 13 - Índices Cofenéticos para os diferentes critérios de "clustering" a partir de Distâncias Euclidianas. Parcela masculina, tamanho e forma (73 populações, 32 variáveis).

\begin{tabular}{lc}
\hline Método de Agregação & Índice Cofenético - r \\
\hline \hline Simples & 0,10949 \\
Composta & 0,17674 \\
média não ponderada & $\mathbf{0 , 3 7 5 1 4}$ \\
média ponderada & 0,34845 \\
\hline
\end{tabular}

As Distâncias de Mahalanobis para a parcela masculina (tamanho e forma) foram calculadas para dois níveis de agregação: um primeiro, populacional (como apresentado nas analises anteriores) e um segundo, aqui denominado de "grandes regiões geográficas" (classificação apresentada na Tabela 2). Somente o agrupamento com melhor Índice Cofenético está apresentado graficamente, bem como o gerado pelo método de Ward (sem Índice Cofenético). De acordo com os valores das Distâncias de Mahalanobis para o agrupamento em populações locais (Tabela 14) é possível observar que as populações mais próximas dos Paleoíndios de Lagoa Santa são os peruanos, russos, mongóis, indianos do norte, andamaneses, antigos sudeste asiáticos, birmaneses e antigos iranianos, enquanto que os mais distantes são os 
Tabela 14 - Matriz de Distâncias de Mahalanobis (agrupamento realizado por populações locais). Parcela masculina, tamanho e forma.

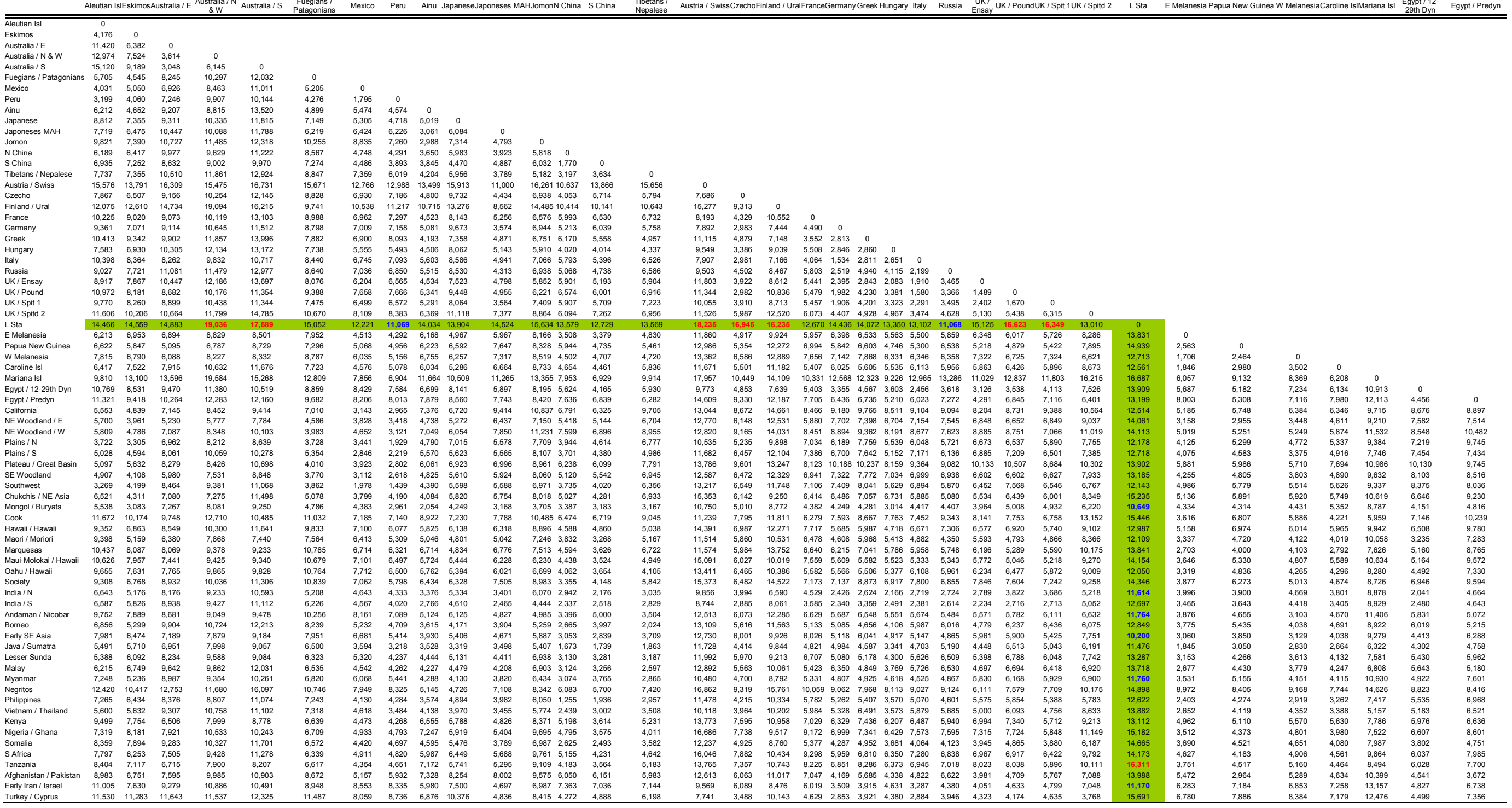


(Continuação) Tabela 14 - Matriz de Distâncias de Mahalanobis (agrupamento realizado por populações locais). Parcela masculina, somente forma.

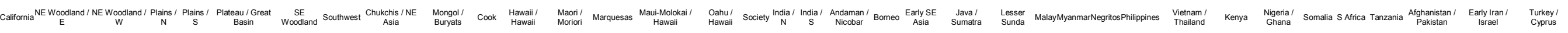

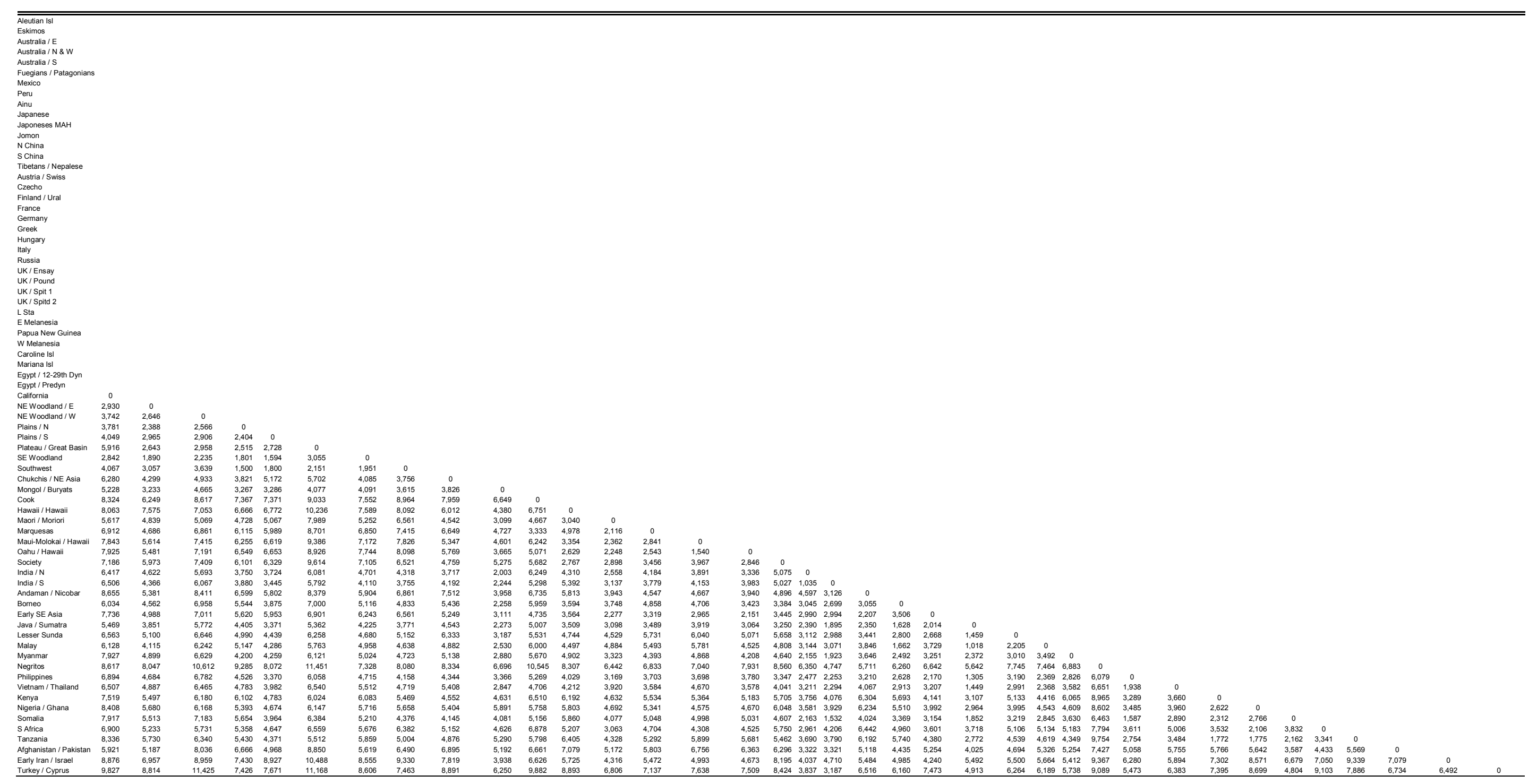


australianos, austríacos, tchecos, finlandeses, do Reino Unido (Poundbury e Spitalfield 1) e tanzanês. O Escalonamento Multidimensional gerado a partir da matriz de Distâncias de Mahalanobis para a parcela masculina para dados de tamanho e forma (Figura 25) apresenta a população de Lagoa Santa como outlier. Para as demais populações, alguns agrupamentos se destam, como é o caso das populações australianas e européias/peri-mediterrânicas. Os nativos americanos misturam-se com as populações africanas sub-saarianas. Já as populações melanésicas estão próximas das populações polinésicas em posição mais centralizada no gráfico. As populações do Sudeste e Leste Asiático estão extamente na porção central do gráfico com grande sobreposição de suas elipses.

As Distâncias de Mahalanobis apresentadas na Tabela 15 diz respeito ao agrupamento realizado sobre grandes regiões geográficas e apresenta os grupos mais proximamente associados à população de Lagoa Santa as do Nordeste, Oeste e Sudeste Asiáticos, sendo as mais distantes as populações australianas e micronésicas.

De acordo com a Tabela 16 os valores dos Índices Cofenéticos tanto no agrupamento por população local quanto por grandes regiões geográficas apresentam valores muito baixos $(r<0,70)$. No entanto, o dendrograma produzido por ligação pela média não ponderada $(r>0,4)$ e o produzido pelo método de Ward para grandes regiões geográficas estão apresentados nas Figuras 26 e 27, respectivamente. A Figura 26 (média não-ponderada) apresenta uma grande lógica geográfica. Os nativos americanos agrupam-se entre si e têm as populações da região Ártica como grupo mais próximo. As 


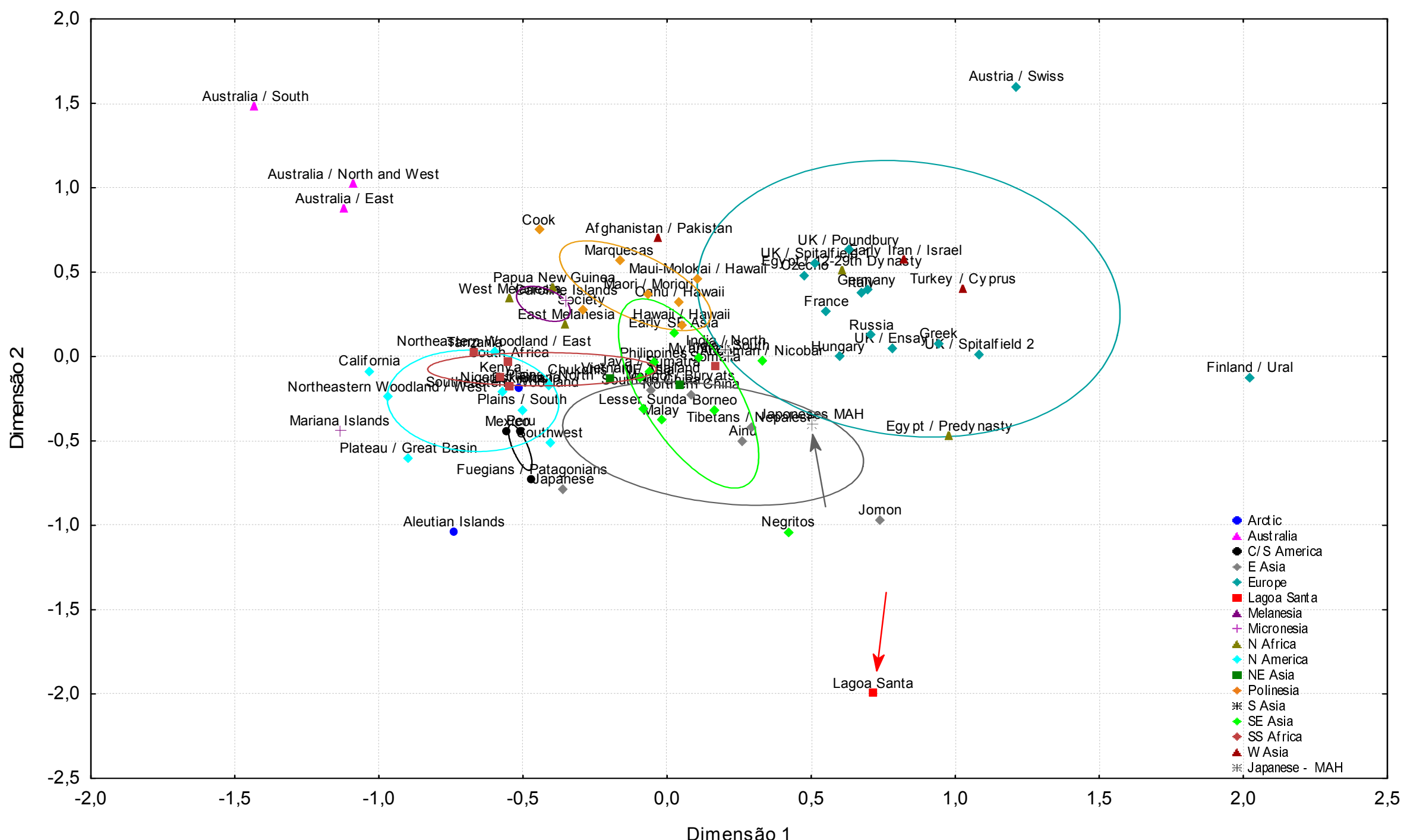

Figura 25 - Escalonamento Multidimensional produzido sobre a matriz de Distâncias de Mahalanobis (agrupamento por populações locais). Parcela masculina, somente tamanho e forma. 
Tabela 15 - Matriz de Distâncias de Mahalanobis (populações agrupadas por grandes regiões geográficas). Parcela masculina, tamanho e forma (73 populações, 32 variáveis).

\begin{tabular}{|c|c|c|c|c|c|c|c|c|c|c|c|c|c|c|c|c|}
\hline & Arctic & Australia & $\mathrm{C} / \mathrm{S}$ América & E Asia & Europe & L Sta & Melanesia & Micronesia & N Africa & N America & NE Asia & Polinesia & S Asia & SE Asia & SS Africa & W Asia \\
\hline Arctic & 0 & & & & & & & & & & & & & & & \\
\hline Australia & 8,687 & 0 & & & & & & & & & & & & & & \\
\hline $\mathrm{C} / \mathrm{S}$ America & 2,267 & 7,815 & 0 & & & & & & & & & & & & & \\
\hline E Asia & 4,137 & 8,371 & 2,965 & 0 & & & & & & & & & & & & \\
\hline Europe & 6,410 & 9,079 & 4,945 & 3,347 & 0 & & & & & & & & & & & \\
\hline L Sta & 13,509 & 16,013 & 11,223 & 12,167 & 13,441 & 0 & & & & & & & & & & \\
\hline Melanesia & 5,149 & 6,176 & 4,050 & 3,646 & 4,435 & 12,846 & 0 & & & & & & & & & \\
\hline Micronesia & 7,956 & 11,443 & 5,102 & 5,981 & 7,596 & 14,081 & 4,462 & 0 & & & & & & & & \\
\hline N Africa & 7,877 & 9,192 & 6,253 & 4,588 & 3,092 & 12,424 & 4,995 & 7,952 & 0 & & & & & & & \\
\hline N America & 2,318 & 6,638 & 0,996 & 3,222 & 4,948 & 11,831 & 2,938 & 5,879 & 6,368 & 0 & & & & & & \\
\hline NE Asia & 2,839 & 7,485 & 2,488 & 1,262 & 3,038 & 10,773 & 3,494 & 6,179 & 3,565 & 2,480 & 0 & & & & & \\
\hline Polinesia & 6,277 & 7,009 & 5,003 & 2,608 & 3,657 & 11,863 & 2,573 & 4,551 & 4,925 & 4,519 & 2,858 & 0 & & & & \\
\hline S Asia & 4,658 & 8,868 & 3,382 & 1,851 & 1,520 & 11,740 & 3,328 & 5,721 & 2,482 & 3,357 & 1,681 & 2,504 & 0 & & & \\
\hline SE Asia & 4,382 & 7,637 & 3,203 & 0,983 & 3,012 & 10,977 & 1,863 & 4,507 & 3,373 & 3,137 & 1,698 & 1,668 & 1,425 & 0 & & \\
\hline SS Africa & 5,687 & 7,485 & 3,028 & 3,180 & 4,427 & 13,858 & 2,942 & 4,784 & 4,775 & 3,707 & 3,662 & 2,780 & 2,116 & 2,007 & 0 & \\
\hline W Asia & 6,049 & 7,504 & 4,860 & 3,155 & 1,060 & 10,842 & 3,700 & 7,023 & 2,376 & 4,723 & 2,639 & 2,691 & 1,510 & 2,153 & 3,975 & 0 \\
\hline
\end{tabular}


populações asiáticas (Leste e Sudeste) apresentam como grupo mais próximo o Nordeste Asiático. As populações européias estão intimamente associadas às populações do Oriente Médio (W Asia) e egípcias (N África). A Melanésia associa-se às populações africanas sub-saarianas. Já as populações da Micronésia, as australianas e Lagoa Santa comportam-se como outliers.

Tabela 16 - Índices Cofenéticos para os diferentes critérios de "clustering" a partir de Distâncias de Mahalanobis. Parcela masculina, tamanho e forma (73 populações, 32 variáveis).

\begin{tabular}{llc}
\hline Classificação & Método de Agregação & Índice Cofenético - r \\
\hline \hline Populacional & simples & 0,21883 \\
Populacional & composta & 0,20421 \\
Populacional & média não ponderada & 0,39976 \\
Populacional & média ponderada & 0,37138 \\
Grandes regiões & simples & 0,36541 \\
Grandes regiões & composta & 0,30824 \\
Grandes regiões & média não ponderada & $\mathbf{0 , 4 2 8 7 3}$ \\
Grandes regiões & média ponderada & 0,41186 \\
\hline
\end{tabular}

A árvore produzida pelo método de Ward (Figura 27) mostra também agrupamentos com certa lógica geográfica. Os nativos americanos formam um grupo coeso, que se diferencia de um outro cluster mais amplo, formado por populações do Velho Mundo, exceto Austrália. Este segundo cluster é formado por três sub-grupos: um formado pelas populações do Leste da Ásia, outro, por Melanésia, Polinésia e África Sub-saariana, e um terceiro, formado pelos europeus, asiáticos ocidentais e Norte da África. Lagoa Santa comporta-se como outlier, não se aproximando de nenhuma população mundial específica. É necessário enfatizar a locação inesperada dos australianos com os nativos americanos.

O Escalonamento Multidimensional gerado a partir das Distâncias de 


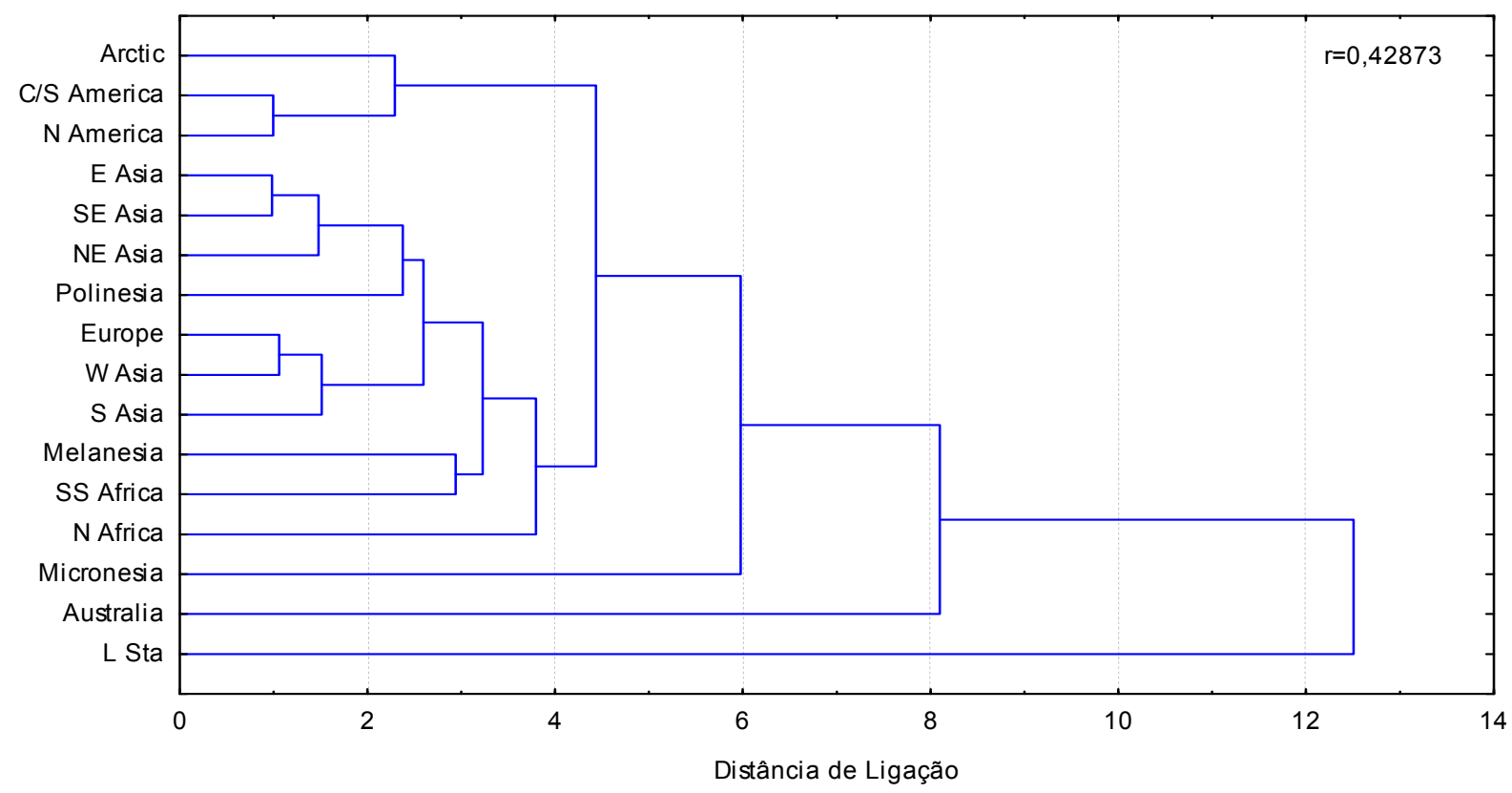

Figura 26 - Dendrograma produzido pelo critério de ligação pela média não-ponderada sobre a matriz de Distâncias de Mahalanobis (populações agrupadas por grandes regiões geográficas). Parcela masculina, tamanho e forma.

Mahalanobis confirma a posição de outlier da população de Lagoa Santa (Figura 28) observada nas análises de agrupamento (Figura 26 e 27). A posição de outlier dos paleoíndios de Lagoa Santa não permite explorar de nenhuma forma as afinidades biológicas desses em relação às demais populações. A Austrália também comporta-se como outlier. As populações nativas americanas estão próximas às do Ártico e da África Sub-saariana. As populações asiáticas estão associadas entre si. Os europeus estão, mais um vez, relacionados as populações do Oriente Médio e Oeste Asiáticos. E, por fim, os melanésicos estão próximos aos polinésicos.

Na Tabela 17 é possível observar que, a parcela masculina, quando corrigida por C-Score, ou seja, levando-se em consideração somente forma, distribuiu melhor a variância original explicada por cada componente na Análise de Componentes Principais, principalmente entre o Primeiro Componente e os 


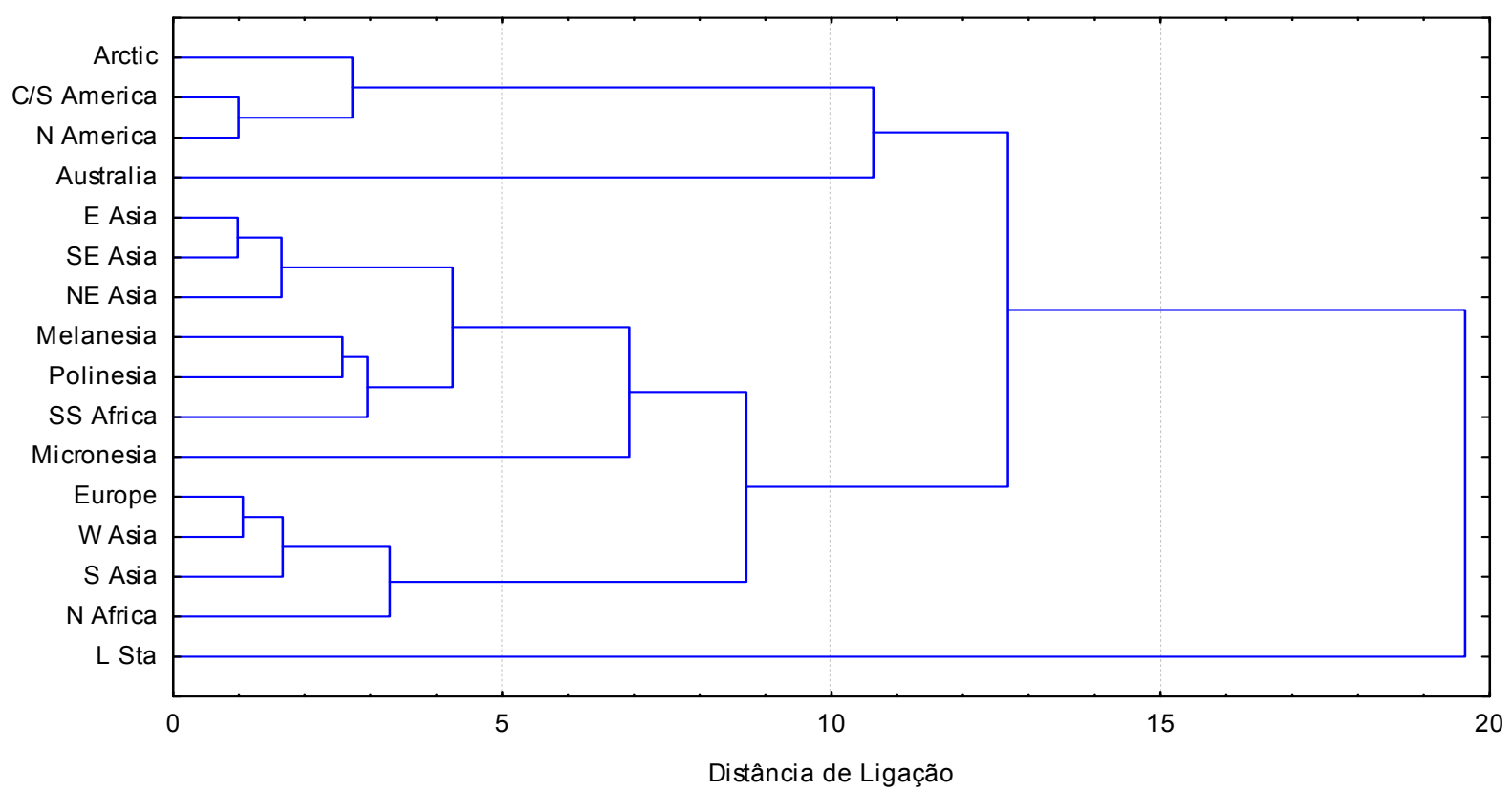

Figura 27 - Dendrograma produzido pelo critério de ligação de Ward sobre matriz de Distâncias de Mahalanobis (com as populações agrupadas por grandes regiões geográficas). Parcela masculina, tamanho e forma.

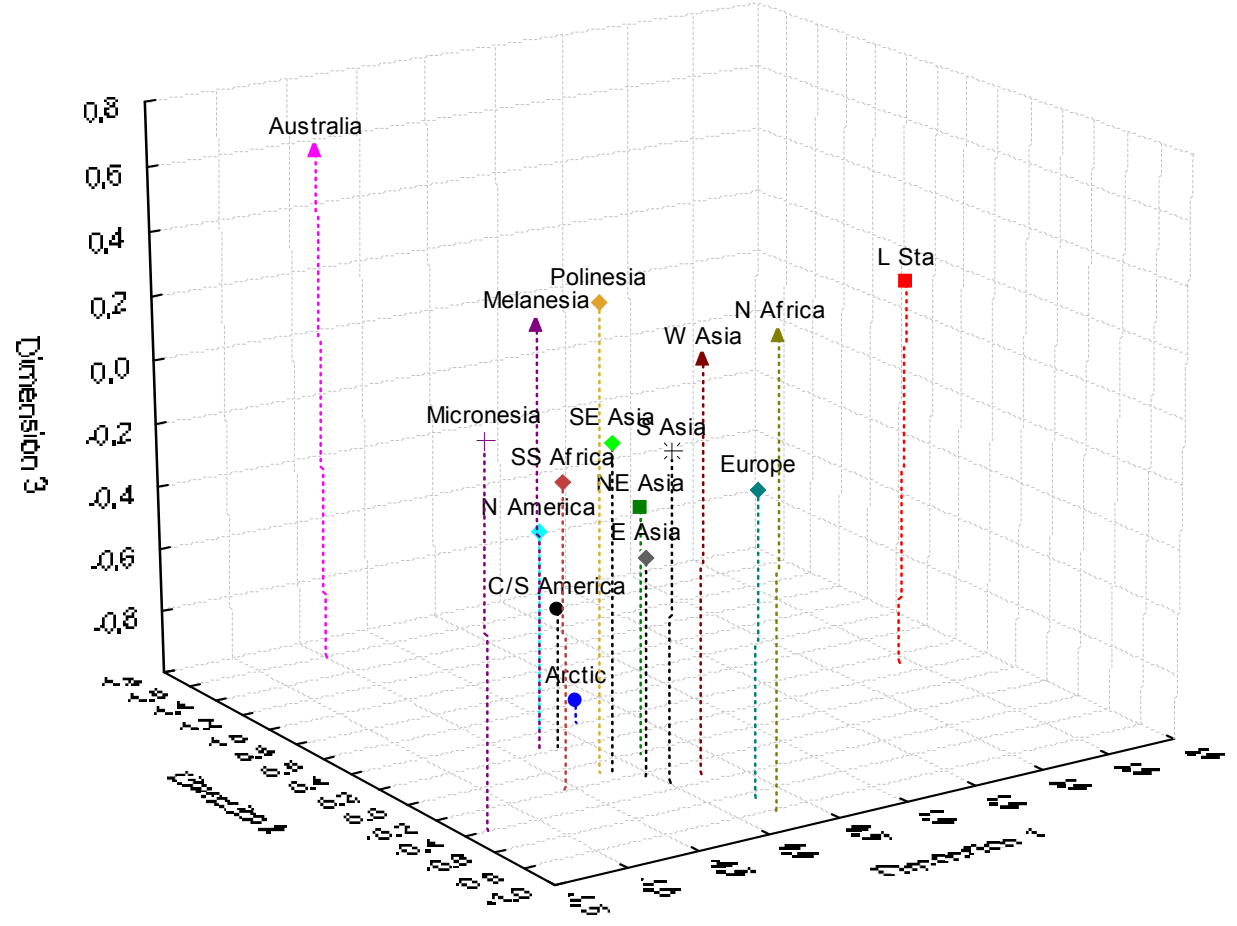

Figura 28 - Gráfico tridimensional produzido por Escalonamento Multidimensional sobre a matriz de Distâncias de Mahalanobis (com as populações agrupadas por grandes regiões geográficas). Parcela masculina, tamanho e forma). 
demais. Na representação gráfica do decaimento da explicabilidade dos compenentes (Figura 29) é nítida a ausência de queda abrupta após o Primeiro Componente, como ocorreu na análise anterior.

Tabela 17 - Autovalores e percentuais de variância explicada pelos primeiros dezessete componentes principais. Parcela masculina, somente forma ( 73 populações, 32 variáveis).

\begin{tabular}{ccccc}
\hline $\begin{array}{c}\text { Componente } \\
\text { Principal }\end{array}$ & Autovalor & $\begin{array}{c}\text { \% Total de } \\
\text { Variância Explicada }\end{array}$ & $\begin{array}{c}\text { Autovalor } \\
\text { Cumulativo }\end{array}$ & $\begin{array}{c}\% \\
\text { Cumulativa }\end{array}$ \\
\hline \hline 1 & 0,685012 & 31,15644 & 0,685012 & 31,1564 \\
2 & 0,323947 & 14,73411 & 1,008959 & 45,8905 \\
3 & 0,230537 & 10,48553 & 1,239496 & 56,3761 \\
4 & 0,165538 & 7,52916 & 1,405034 & 63,9052 \\
5 & 0,111343 & 5,06422 & 1,516377 & 68,9695 \\
6 & 0,088576 & 4,02872 & 1,604953 & 72,9982 \\
7 & 0,079242 & 3,60416 & 1,684195 & 76,6023 \\
8 & 0,060318 & 2,74343 & 1,744512 & 79,3458 \\
9 & 0,053545 & 2,43539 & 1,798057 & 81,7812 \\
10 & 0,051879 & 2,35964 & 1,849937 & 84,1408 \\
11 & 0,045397 & 2,06478 & 1,895333 & 86,2056 \\
12 & 0,038439 & 1,74832 & 1,933772 & 87,9539 \\
13 & 0,032464 & 1,47656 & 1,966236 & 89,4305 \\
14 & 0,029446 & 1,33931 & 1,995683 & 90,7698 \\
15 & 0,026468 & 1,20385 & 2,022151 & 91,9736 \\
16 & 0,024525 & 1,11548 & 2,046676 & 93,0891 \\
17 & 0,022331 & 1,01570 & 2,069007 & 94,1048 \\
\hline
\end{tabular}

Na Tabela 18 é apresentada a correlação das variáveis originais com os dois primeiros componentes principais extraídos dos dados corrigidos por CScore, ou seja, somente forma, na qual diversas variáveis mostram correlações altas em todos os grupos dentários tanto nos diâmetros mesiodistais quanto nos bucolinguais (as correlações podem ser visualizadas também na Figura 30). As correlações significativas (maiores que 0,5 ) negativas entre as variáveis originais e o Primeiro Componente referem-se aos diâmetros mesiodistais, enquanto que as correlações positivas referem-se aos diâmetros bucolinguais. As correlações dos diâmetros mesiodistais não estão restritas a um único grupo 
dentário específico, o que dificulta uma interpretação morfológica, entretanto, é possível observar que as maiores correlações ocorrem nos incisivos laterais e nos caninos, tanto superiores quanto inferiores. Os diâmetros bucolinguais também apresentam alta correlação com todos os grupos dentários, todavia, as maiores correlações (maiores que 0,8 ) ocorrem nos incisivos inferiores e no segundo pré-molar inferior. As populações que estão na porção esquerda da Figura 31 são aquelas com dentes mais lateralizados, ao passo que aquelas na porção esquerda apresentam dentes mais expandidos no sentido anteroposterior, ou seja, mais espessos.

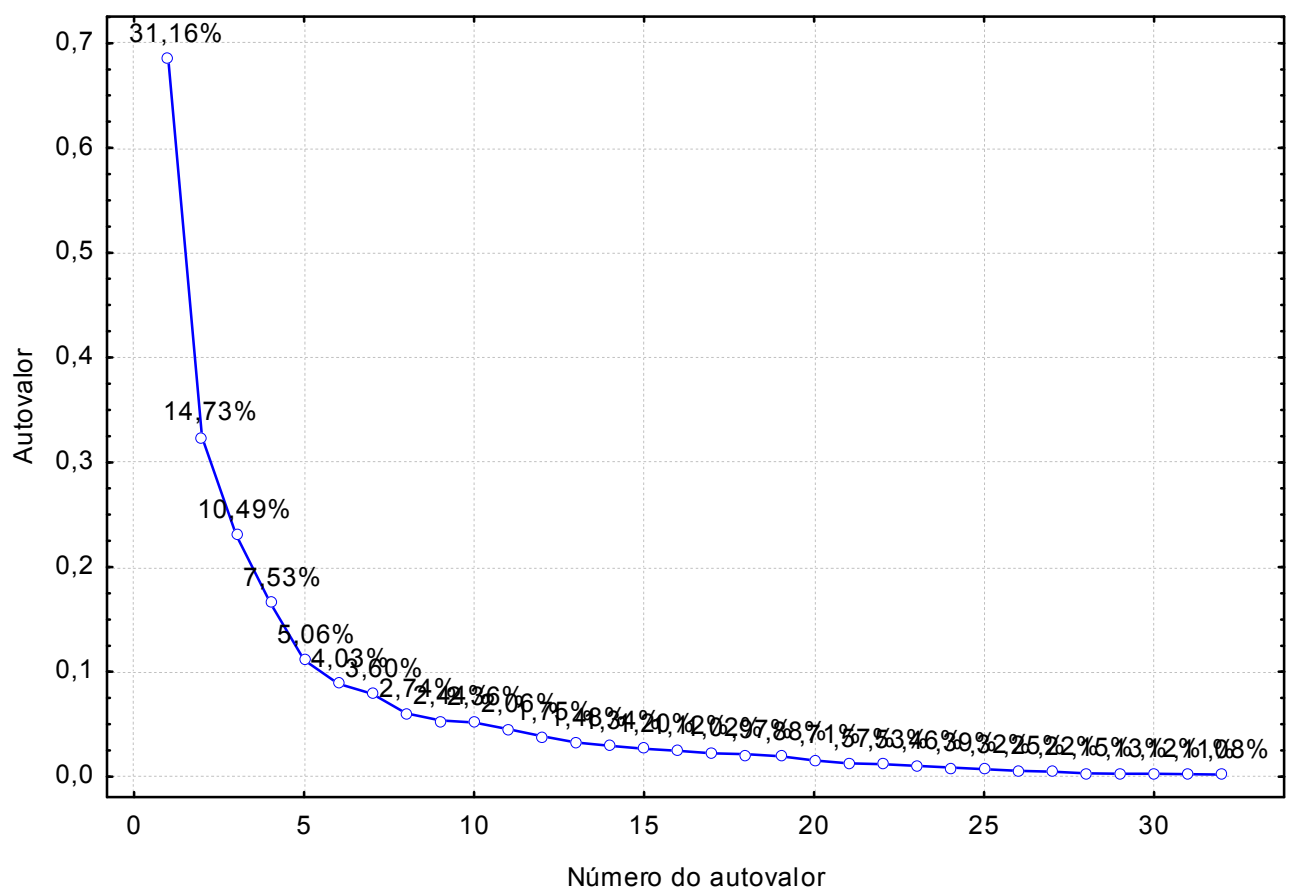

Figura 29 - Screeplot representando o decaimento das porcentagens de variância explicada por cada Componente Principal. Parcela masculina, somente forma (73 populações, 32 variáveis).

No que diz respeito as correlações entre as variáveis originais e o Segundo Componente Principal (Tabela 18), a interpretação morfológica é regida pelos primeiros pré-molares com as maiores correlações. Em ambos os 
Tabela 18 - Correlação entre as variáveis originais e os componentes principais extraídos. Parcela masculina, somente forma (73 populações, 32 variáveis).

\begin{tabular}{lcc}
\hline & Fator 1 & Fator 2 \\
\hline \hline MD I1 U & $-0,1193$ & 0,5753 \\
MD I U & $-0,6578$ & 0,0642 \\
MD C U & $-0,5519$ & $-0,1861$ \\
MD PM1 U & $-0,4447$ & $-0,7394$ \\
MD PM2 U & $-0,5529$ & $-0,3315$ \\
MD M1 U & $-0,5066$ & 0,3818 \\
MD M2 U & $-0,4778$ & 0,2179 \\
MD M3 U & $-0,0276$ & 0,5535 \\
MD I1 L & $-0,4632$ & 0,1857 \\
MD I2 L & $-0,6533$ & 0,3186 \\
MD C L & $-0,6450$ & $-0,1113$ \\
MD PM1 L & $-0,0698$ & $-0,7694$ \\
MD PM2 L & $-0,0411$ & $-0,4276$ \\
MD M1 L & $-0,6265$ & $-0,1793$ \\
MD M3 L & 0,0114 & 0,5219 \\
BL I1 U & 0,3528 & 0,3528 \\
BL I2 U & 0,4266 & 0,0682 \\
BL C U & 0,5991 & 0,2868 \\
BL PM1 U & 0,2245 & $-0,7980$ \\
MD M2 L & $-0,4275$ & 0,3532 \\
BL PM2 U & 0,6649 & $-0,3934$ \\
BL M1 U & $-0,0016$ & 0,4947 \\
BL M2 U & 0,5027 & 0,4303 \\
BL M3 U & 0,7015 & 0,1822 \\
BL I1 L & 0,8260 & 0,2034 \\
BL I2 L & 0,8072 & 0,0763 \\
BL C L & 0,5987 & 0,2407 \\
BL PM1 L & 0,6684 & $-0,5805$ \\
BL PM2 L & 0,8071 & $-0,2661$ \\
BL M1 L & $-0,4083$ & 0,1713 \\
BL M2 L & $-0,1606$ & 0,2497 \\
BL M3 L & $-0,0664$ & 0,1416 \\
\hline & 0,550 & 0 \\
\hline
\end{tabular}

*destaque em vermelho para correlações altas maiores que 0,5 , sublinado para as correlações maiores que 0,9 .

diâmetros os primeiros pré-molares (tanto inferiores quanto superiores) apresentam correlação negativa com o Segundo Componete Principal. Correlações positivas maiores que 0,5 podem ser observadas apenas no diâmetro mesiodistal dos incisivos centrais superiores e nos terceiros molares. Isto quer dizer que as populações distribuídas nos quadrantes inferiores apresentam pré-molares mais robustos. Já nos quadrantes superiores 
posicionam-se as populações que possuem incisivos e molares mais proeminentes.

A projeção das correlações entre as variáveis originais e os dois primeiros componentes é apresentada na Figura 30, na qual as variáveis estão dispersas por todos os quadrantes do morfo-espaço. Ocorreu novamente um agrupamento das projeções dos dentes incisivos na porção central superior (em verde). As projeções dos diâmetros dos molares estão concentradas na área superior do gráfico (em laranja), ao passo que as projeções referentes aos prémolares (em azul) encontram-se divididas na porção inferior do mesmo.

No gráfico da Análise de Componentes Principais do morfo-espaço formado pelos dois primeiros componentes da parcela masculina para tamanho e forma da Figura 31 quatro conjuntos populacionais apresentam-se bastantes distintos: as populações nativas americanas no extremo da metade esquerda, são caracterizadas pelos diâmetros mesiodistais dos dentes anteriores e molares; as populações australianas na porção centro-superior, distinguidas principalmente pelos diâmetros dos dentes molares; as populações européias na porção superior-direita do morfo-espaço, definidas pelos diâmetros bucolinguais dos dentes anteriores e molares; e as populações asiáticasmelanésicas-africanas na área central da figura regidos principalmente pelos pré-molares. As populações européias são acompanhadas pelas populações do Oeste Asiático e egípcias. Tal associação é esperada já que essas populações peri-mediterrânicas estiveram em contato íntimo ao longo da história recente. A elipse de dispersão do Leste Asiático alongada-se em direção à esquerda do gráfico por causa dos Ainu, que, por sua vez, se aproximam dos nativos 


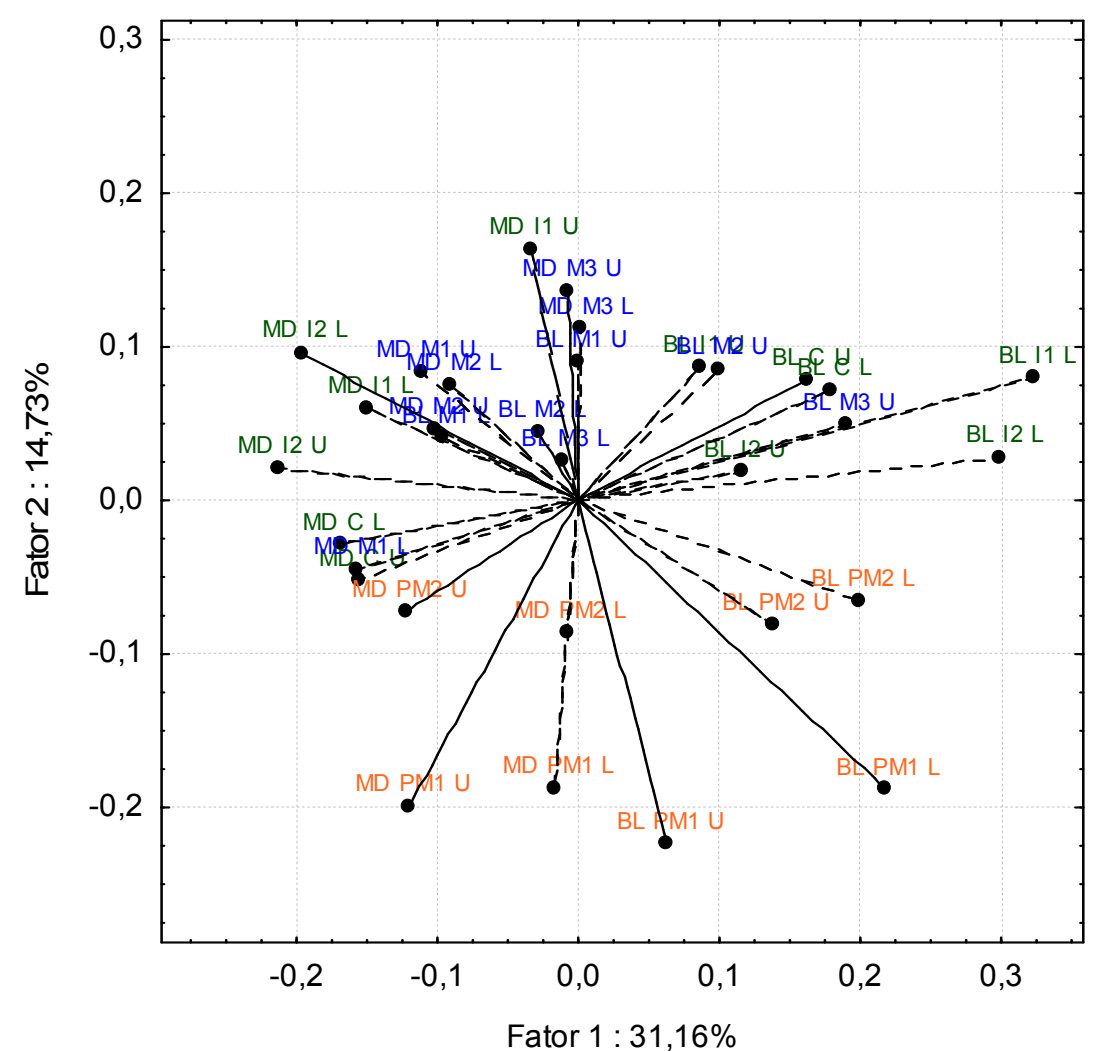

Figura 30 - Projeção das variáveis no morfo-espaço definido pelos dois primeiros Componentes Principais. Parcela masculina, somente forma (73 populações, 32 variáveis).

americanos, e pela posição dos japoneses que se comportam como outliers. As populações africanas sub-saarianas estão intimamente associadas às populações melanésicas e do Sudeste Asiático. Estas últimas apresentam uma elipse alongada pela posição extrema dos negritos. Nota-se também uma certa sobreposição entre o Sudeste Asiático e a Polinésia, no quadrante inferior direito (Figura 31). Lagoa Santa está situada dentro da elipse de dispersão das populações polinésicas e no limite da elipse de dispersão do Sudeste Asiático.

$\mathrm{Na}$ análise de agrupamento da parcela masculina (somente forma) foram incluídos os cinco primeiros CPs levando em consideração a quebra na porcentagem de variância original também representada no screeplot (Figura 


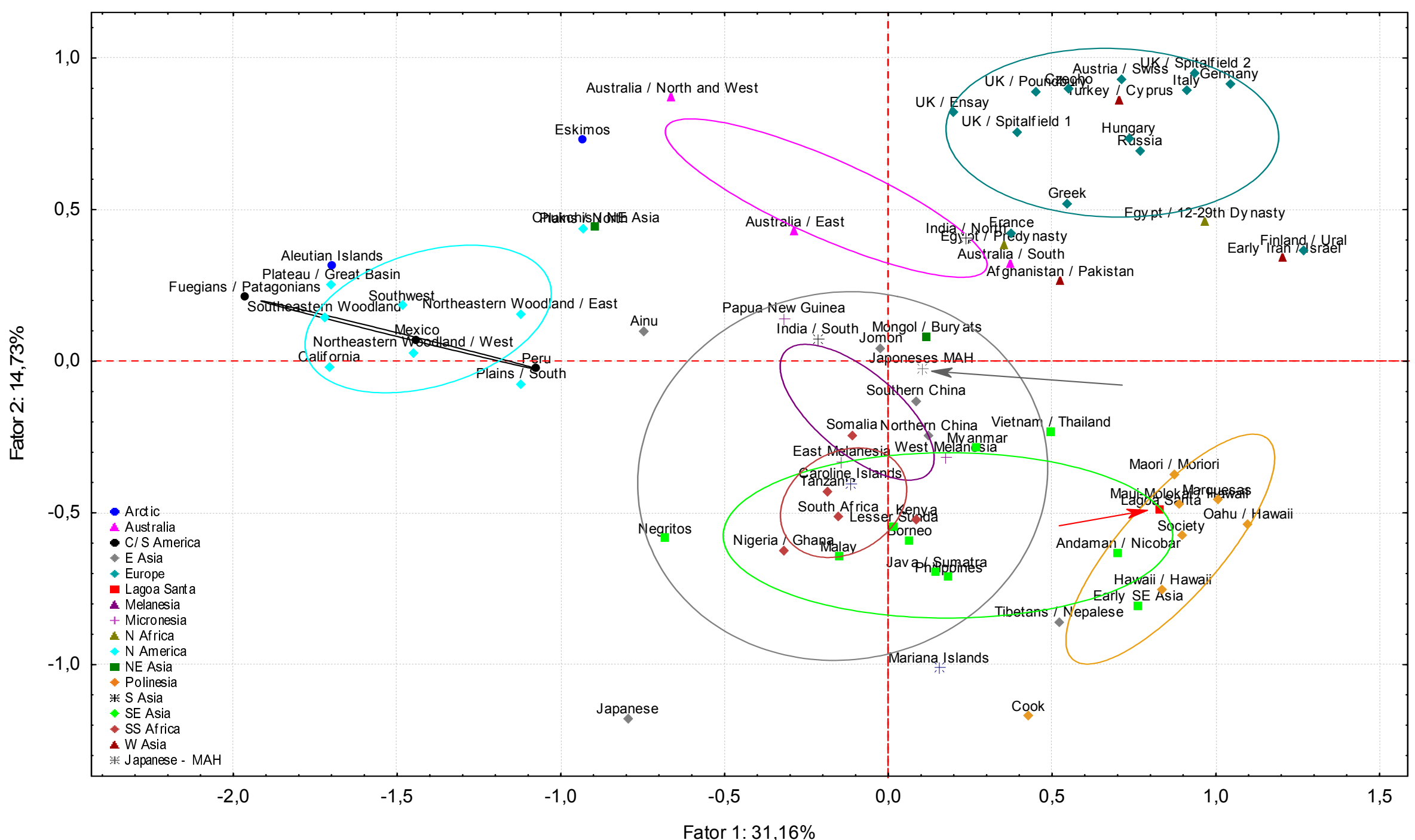

Figura 31 - Morfo-espaço formado pelos $1^{\circ}$ e $2^{\circ}$ componentes principais. Parcela masculina, somente forma (73 populações, 32 variáveis). 
30). A Tabela 19 apresenta os Índices Cofenéticos dos diferentes critérios de agregação (ligação simples, composta, ponderada pela média e não-ponderada pela média).

Tabela 19 - Índices Cofenéticos para os diferentes critérios de "clustering" a partir de Distâncias Euclidianas. Parcela masculina, somente forma ( 73 populações, 32 variáveis).

\begin{tabular}{lc}
\hline Método de Agregação & Índice Cofenético - $\mathbf{r}$ \\
\hline \hline simples & 0,0337 \\
composta & 0,20216 \\
média não ponderada & $\mathbf{0 , 4 3 5 1 8}$ \\
média ponderada & $\mathbf{0 , 3 7 1 8 6}$ \\
\hline
\end{tabular}

Nenhum dos valores dos Índices Cofenéticos (Tabela 19) superou o mínimo esperado $(r=0,70)$. Mais uma vez, os índices estão muito distantes do valor necessário para a validação de qualquer um dos métodos aplicados. No entanto, relaxando o critério de exclusão para valores acima de 0,4, o agrupamento produzido pela média não-ponderada é apresentado na Figura 32 . No dendrograma da Figura 32 pode ser observada uma grande lógica geográfica nos grupos formados. O primeiro agrupamento populacional a divergir é composto pelas populações australianas (excluindo-se os finlandeses que comportam-se como outliers). A próxima grande cissão ocorre na separação das populações nativas americanas em relação às demais do Velho Mundo (por volta de 3,5 unidades de distância de ligação). Logo após, ocorre a separação dos europeus das populações asiáticas, polinésicas, melanésicas e africanas (por volta de 2,9 unidades). As populações melanésias e africanas separam-se quase que 


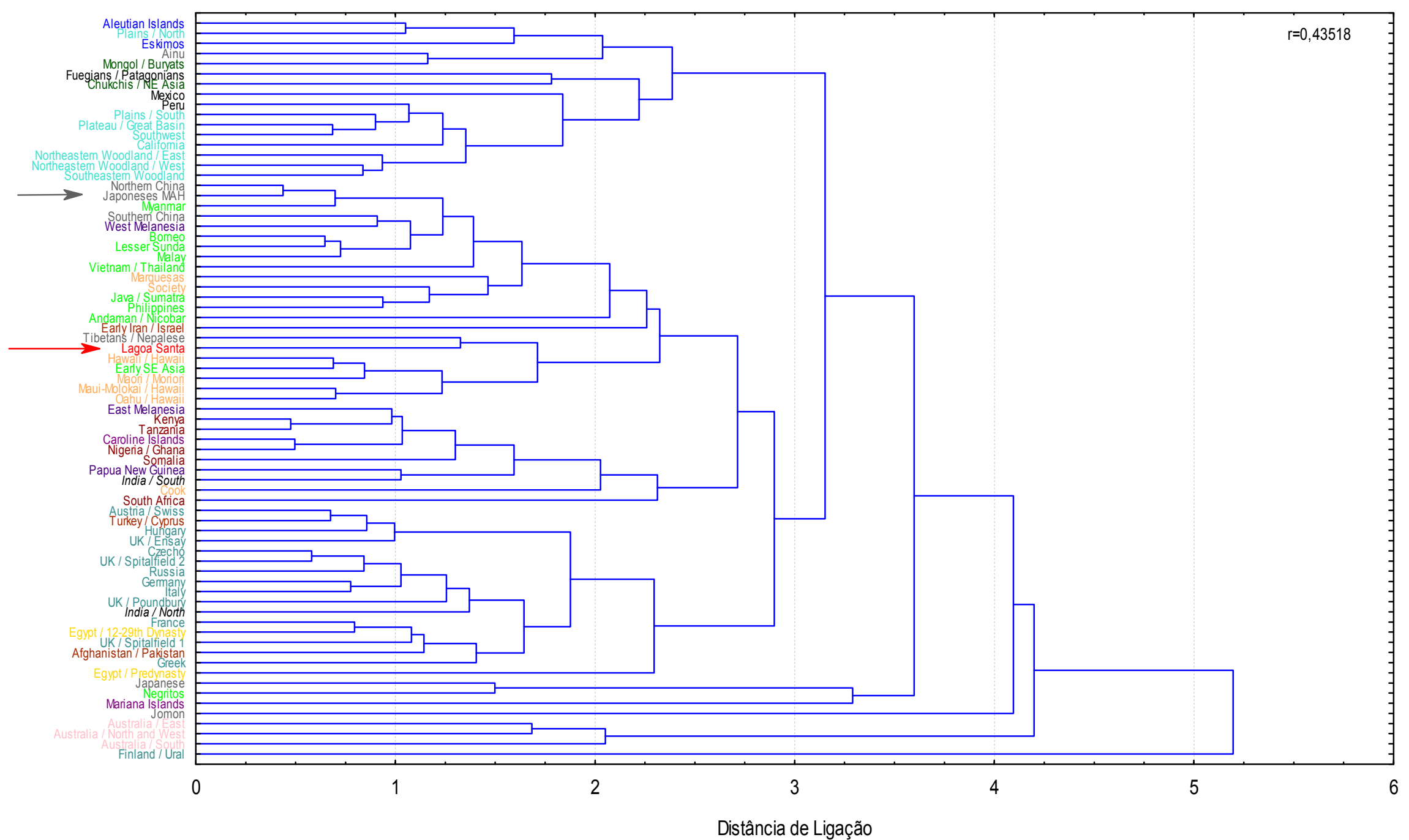

Figura 32 - Dendrograma produzido pelo critério de ligação pela média não-ponderada a partir dos cinco primeiros componentes principais (Distâncias Euclidianas). Parcela masculina, somente forma. 
imediatamente na sequência (em torno de 2,7 unidades). As populações do leste asiático se separam num próximo momento, ao passo que as populações polinésicas e do Sudeste Asiático permanecem estritamente associadas. A população de Lagoa Santa está intimamente associada às populações polinésicas, enquanto a população acessória de japoneses mantem-se associada às populações chinesas.

Já o agrupamento produzido pelo método de Ward, Figura 33, podem ser identificados 7 grandes agrupamentos populacionais com lógica geográfica à uma distância de amálgama de 8,0. Na porção superior do gráfico estão os nativos americanos. Num segundo pequeno agrupamento, logo abaixo, estão as populações australianas. $O$ terceiro agrupamento, também pequeno, condensa as populações africanas. $\mathrm{Na}$ porção mediana do gráfico destacam-se dois subconjuntos, o das populações européias e o das populações do Oriente Médio e norte-africanas. Os dois próximos agrupamentos pertencem predominantemente as populações sudeste-asiáticas e polinésicas, respectivamente. $\mathrm{O}$ agrupamento constrituído predominantemente por populações do Sudeste Asiático é menos estruturado, já o agrupamento das populações da Polinésia é mais coeso e é neste grupo que está inserida a população de Lagoa Santa. A população acessória de japoneses do Museu de Anatomia-USP está novamente associada intimamente à população chinesa.

A Tabela 20 apresenta os Índices Cofenéticos baseados em populações locais e em grandes regiões geográficas (parcela masculina, somente forma) 


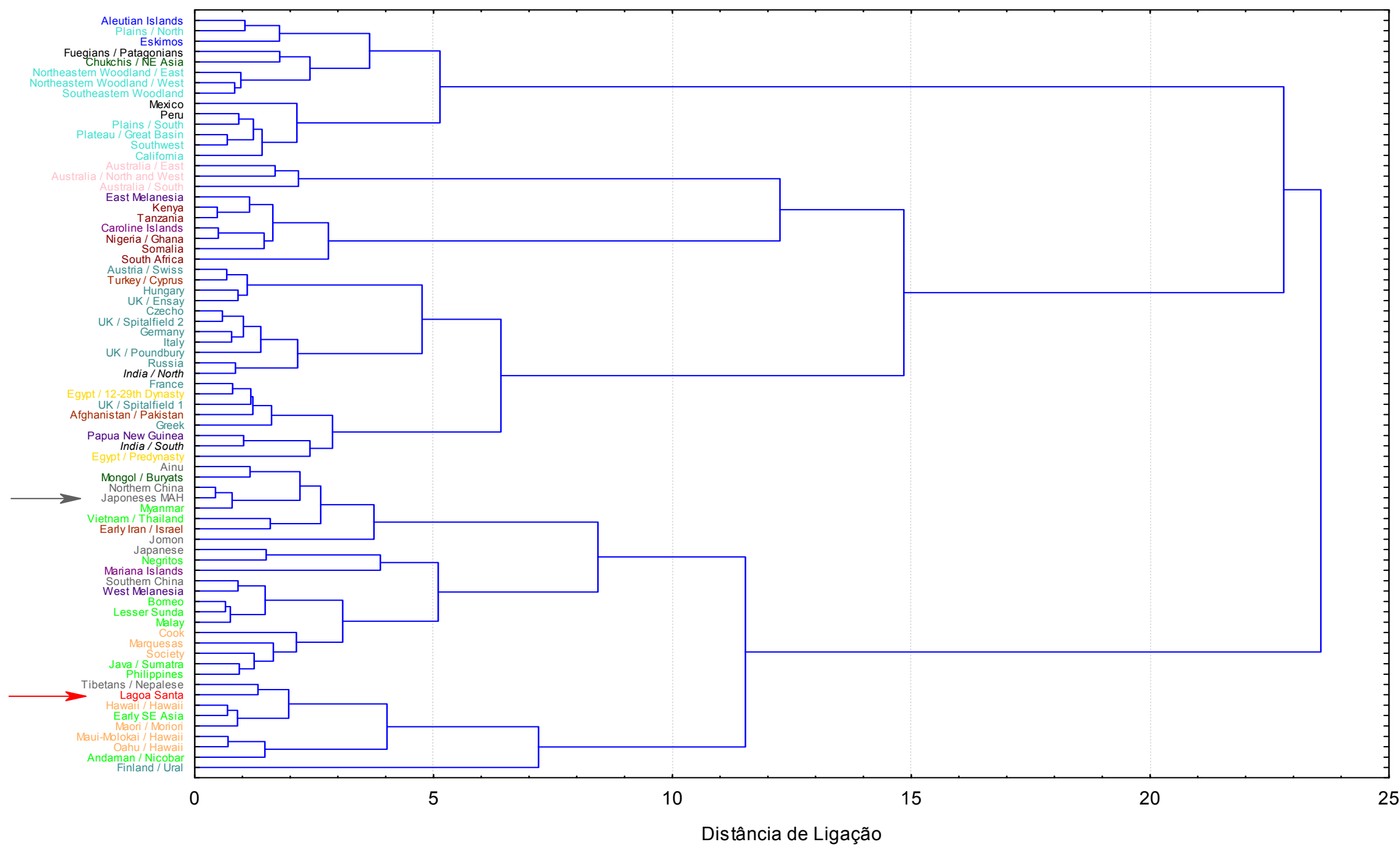

Figura 33 - Dendrograma produzido pelo critério de Ward a partir dos cinco primeiros componentes principais (Distâncias Euclidinas). Parcela masculina, somente forma. 
obtidos a partir das Distâncias de Mahalanobis (Tabela 21 e 22). Os agrupamentos produzidos por critério de média não-ponderada apresentam os maiores valores do Índice Cofenético. De acordo com as distâncias calculadas entre populações locais (Tabela 21), os grupos humanos mais próximos dos Paleoíndios são os gregos, húngaros, italianos, russos, duas populações do Reino Unido (Essay e Poundbury), andamenses, das ilhas Carolinas e indianos do sul; enquanto que as populações mais distantes são as populações australianas, aleutas, japonesas, fueginas, tchecas, melanésicas do leste, egípcias da 12-19th dinastia e havainas.

Tabela 20 - Índices Cofenéticos para os diferentes critérios de "clustering" a partir de Distâncias de Mahalanobis. Parcela masculina, somente forma (73 populações, 32 variáveis).

\begin{tabular}{llc}
\hline Classificação & Método de Agregação & Índice Cofenético - r \\
\hline \hline Populacional & simples & 0,28981 \\
Populacional & composta & 0,18705 \\
Populacional & média não ponderada & $\mathbf{0 , 4 1 7 3 9}$ \\
Populacional & média ponderada & 0,35699 \\
Grandes regiões & simples & 0,36534 \\
Grandes regiões & composta & 0,27171 \\
Grandes regiões & média não ponderada & $\mathbf{0 , 5 3 2 9 4}$ \\
Grandes regiões & média ponderada & 0,51666 \\
\hline
\end{tabular}

A Figura 34 mostra o dendrograma produzido pelo critério de ligação pela média não ponderada, no qual as populações locais, de forma geral, agrupam-se por regiões geográficas, apesar da árvore produzida não formar grupos distintos. É possível observar os nativos americanos intimamente associados às populações do Ártico. As populações do Leste Asiático estão muito ligadas às populações do Nordeste Asiático. As populações do Sudeste Asiático, Polinésias, Melanésias e África Sub-saarina formam blocos distintos e coesos, sem a intromissão de 
Tabela 21 - Matriz de Distâncias de Mahalanobis (agrupamento realizado por populações locais). Parcela masculina, somente forma.

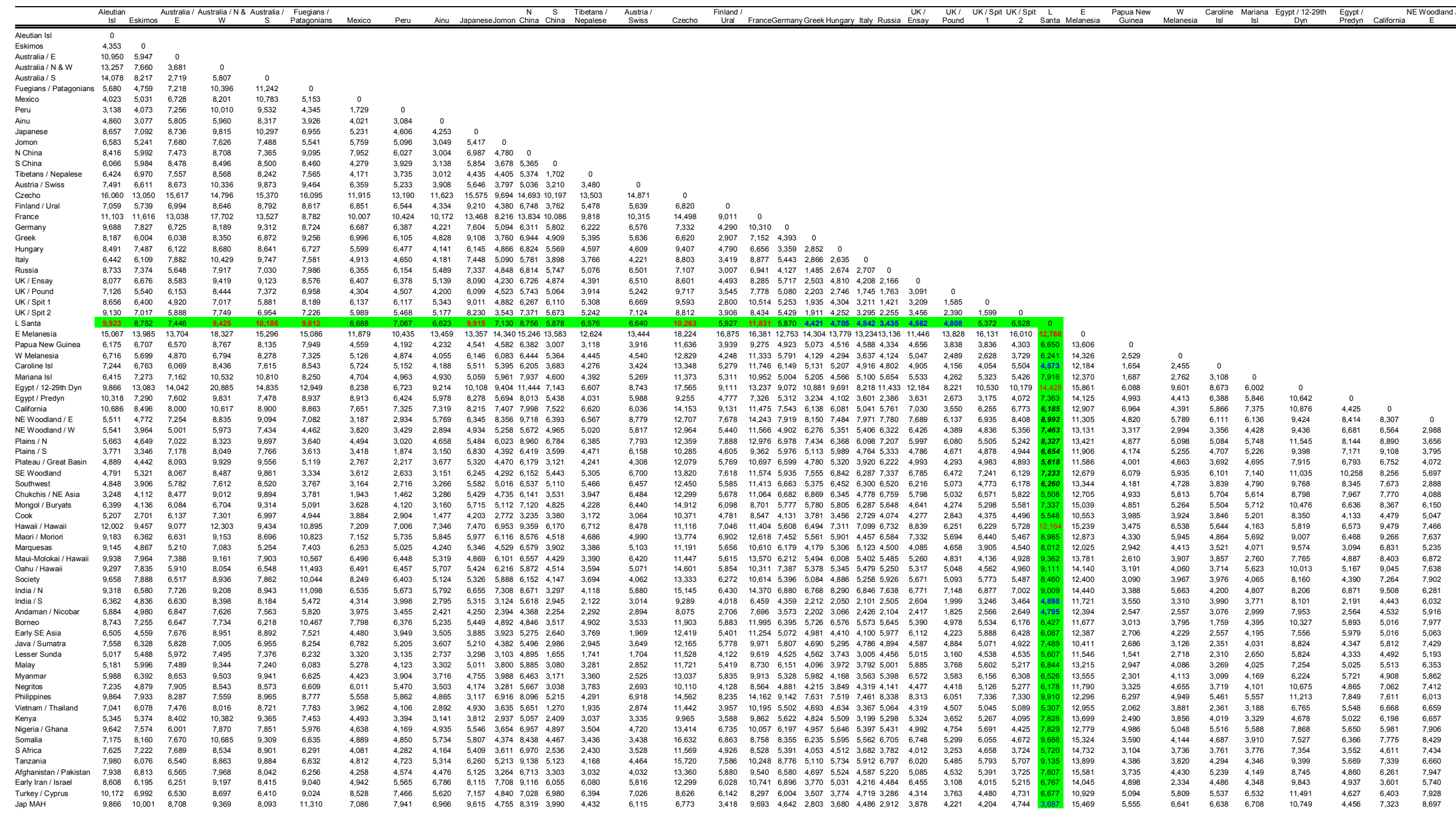


(Continuação) Tabela 21 - Matriz de Distâncias de Mahalanobis (agrupamento realizado por populações locais). Parcela masculina, somente forma.

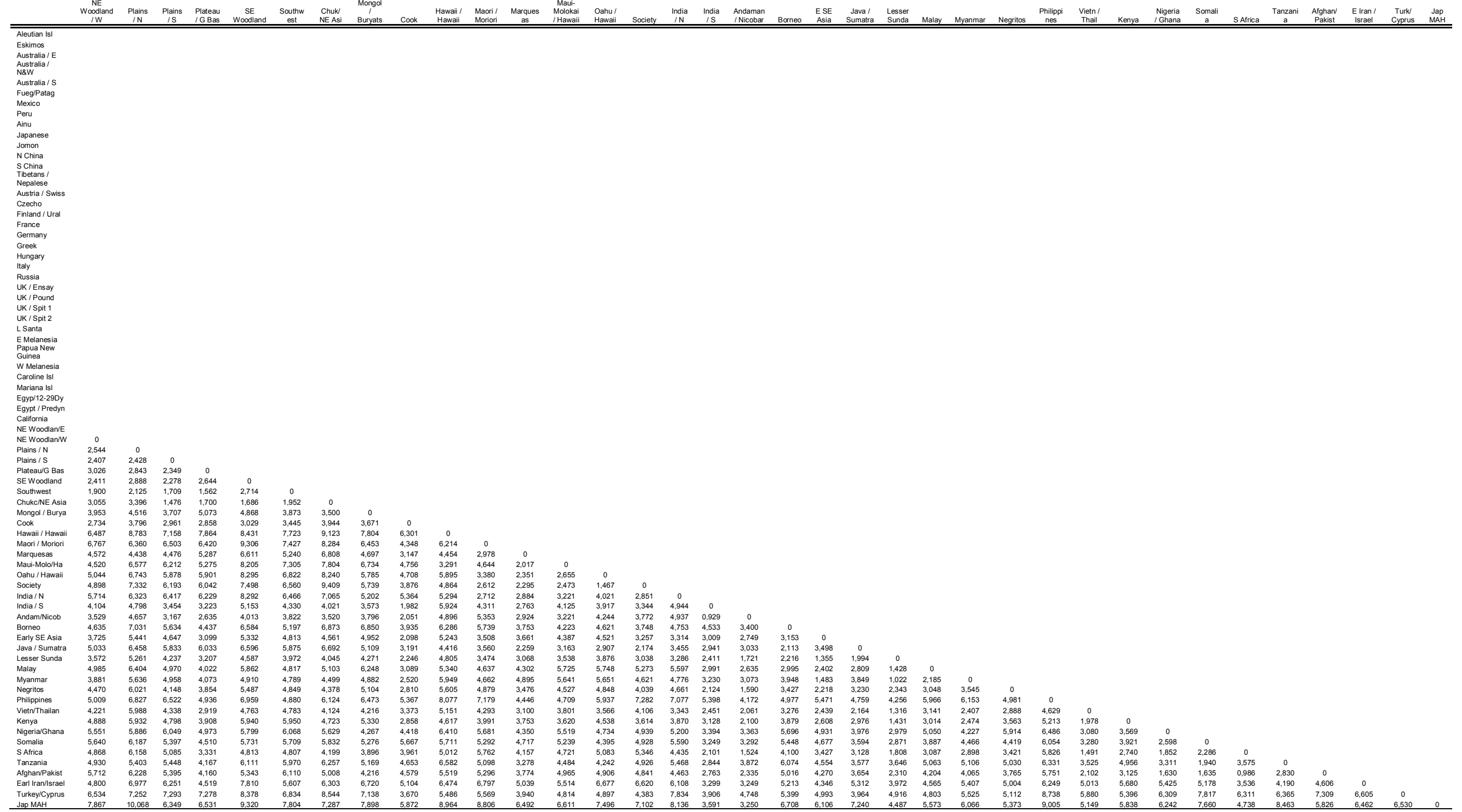




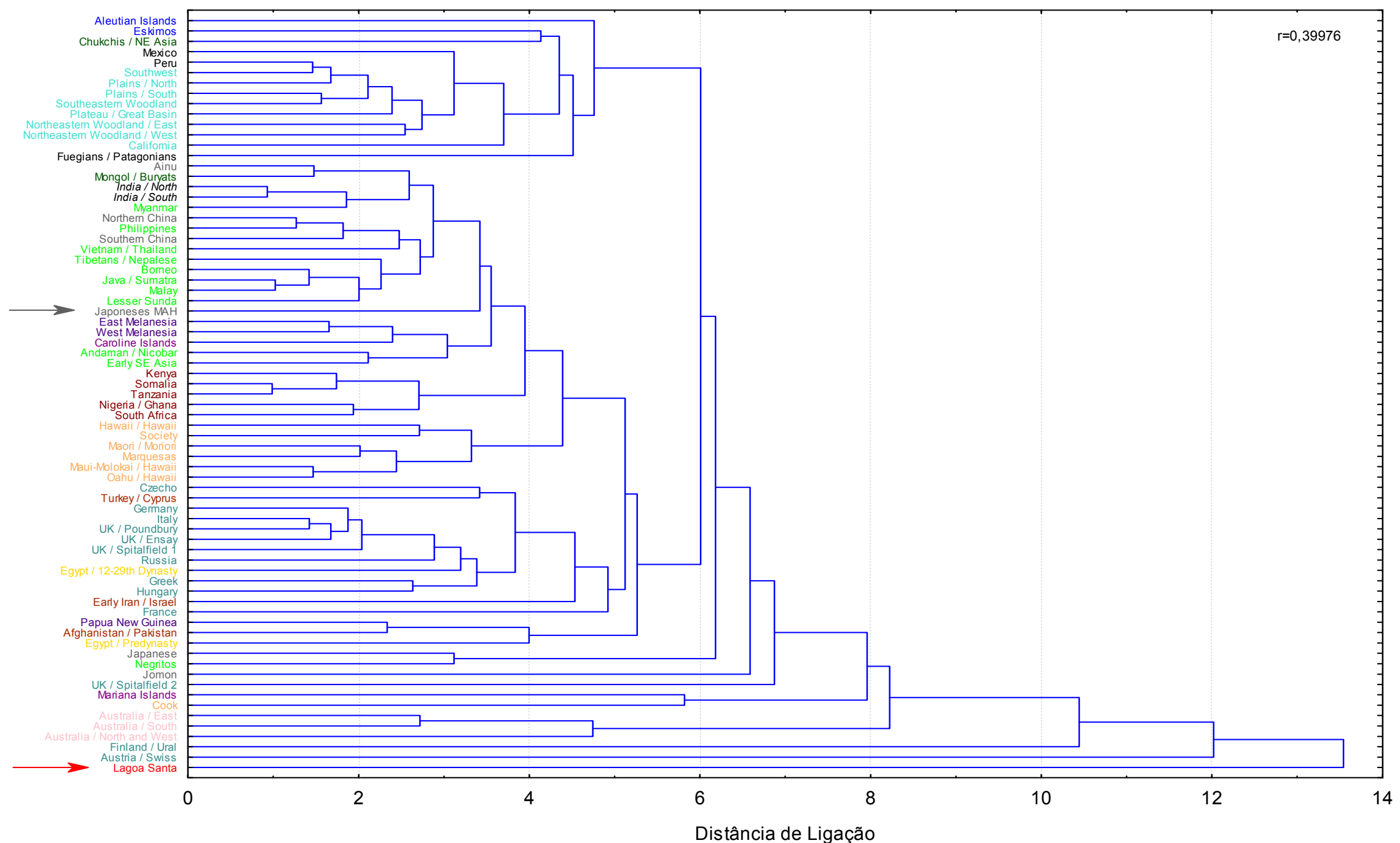

Figura 34 - Dendrograma produzido pelo critério de ligação pela Média não-ponderada sobre a matriz de Distâncias de Mahalanobis (agrupamento por populações locais). Parcela masculina, somente forma. 
populações de outras regiões geográficas. As populações européias estão bem associadas entre si, em conjunto com populações do Oriente Médio e Norte da África. A população de Lagoa Santa comporta-se como outlier, não se associando com nenhuma outra população. Os japoneses do Museu de Anatomia Humana associam-se às populações do Leste e Nordeste Asiáticos. E por fim, as populações australianas associam-se fortemente entre si na parte inferior da Figura 34.

Já na Figura 35, gerada pelo critério de agregação de Ward as populações australianas comportam-se como grupo irmão dos nativos americanos. Um bloco coeso é formado pelas populações do Leste e Sudeste Ásiático, os quais tem a população de Lagoa Santa como grupo irmão. Um outro grupo é formado por populações melanésicas e micronésicas. Um pequeno agrupamento é formado por populações africanas sub-saarianas. As populações polinésicas estão, todas, à exceção da população das ilhas Cook, formando um grupo coeso e distinto. E por fim, as populações européias formam um grupo com populações da Ásia Ocidental e Norte da África. Os japoneses do Museu de Anatomia - USP estão associados às populações do Leste e Nordeste asiático.

O gráfico de Escalonamento Multidimensional gerado a partir das Distâncias de Mahalanobis (Figura 36) calculadas com base em dados de somente forma confirma Lagoa Santa como outlier. Tampouco distingue bem as demais populações mundiais. Os dois únicos conjuntos populacionais que se distinguem bem são os constituídos pelas populações australianas e européias. Os nativos americanos misturam-se com populações da África Sub-Saariana. Já as 


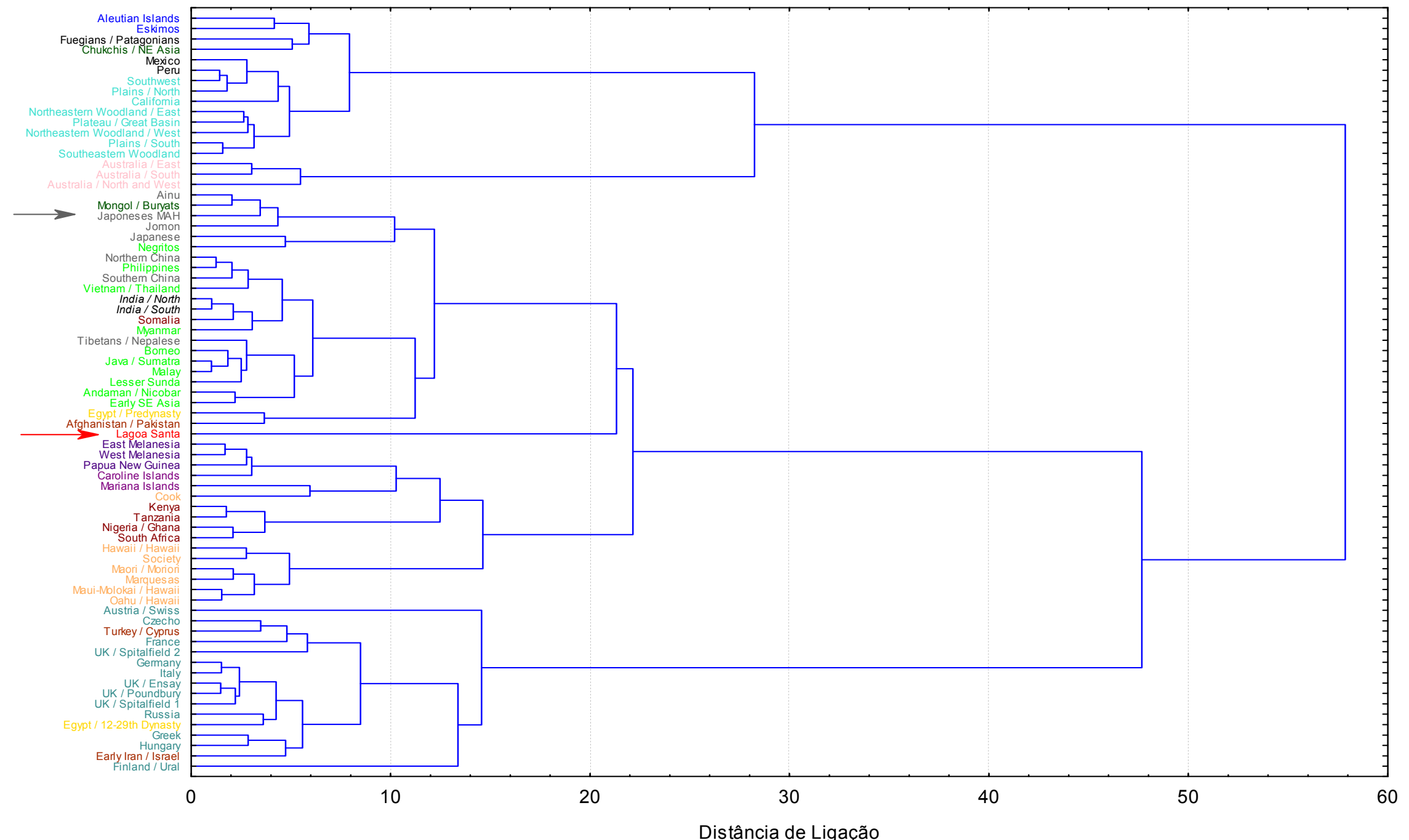

Figura 35 - Dendrograma produzido pelo critério de Ward sobre a matriz de Distâncias de Mahalanobis (agrupamento por populações locais). Parcela masculina, somente forma. 


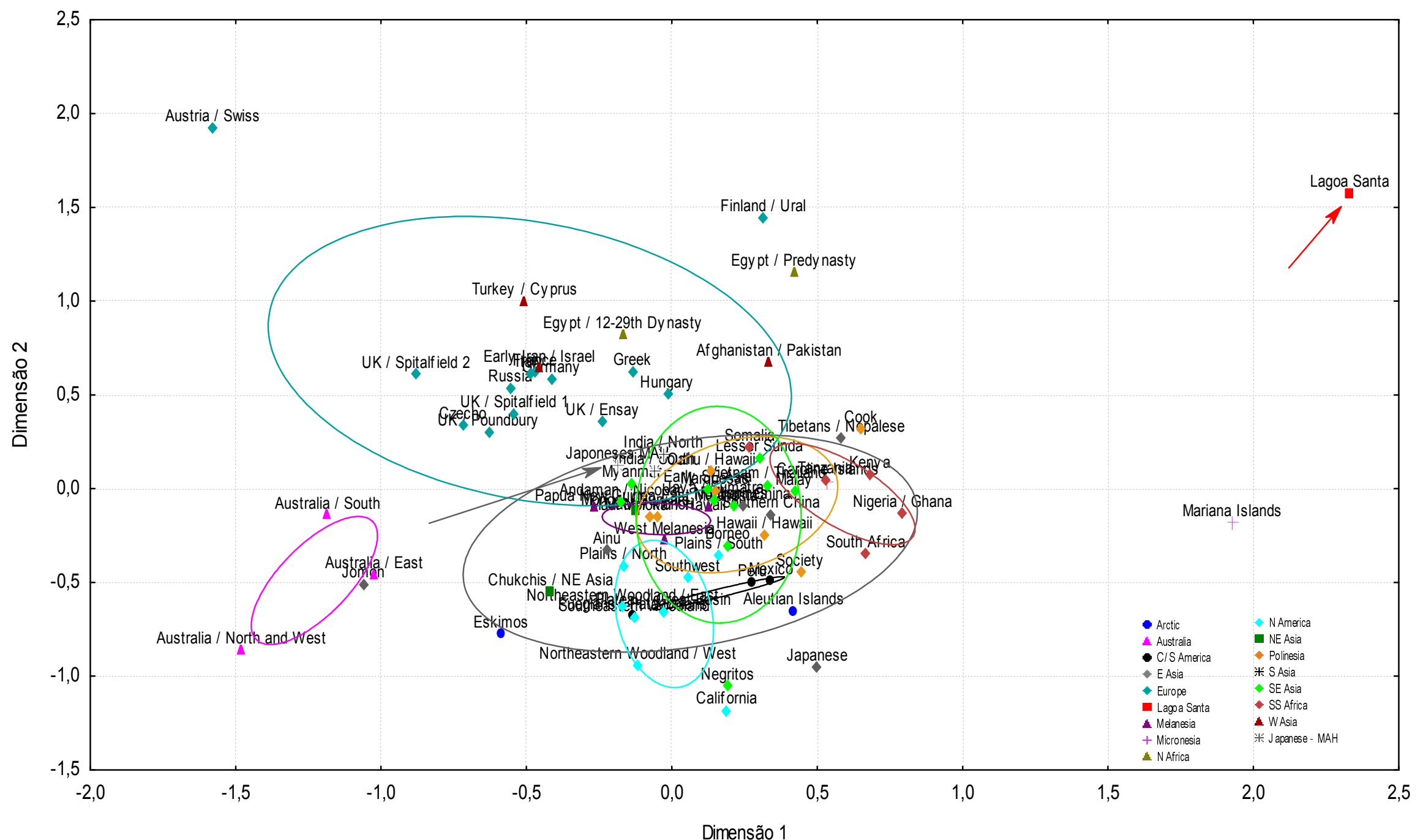

Figura 36 - Escalonamento mutlidimensional produzido sobre a matriz de Distâncias de Mahalanobis (agrupamento por populações locais). Parcela masculina, somente forma. 
populações melanésicas e polinésicas ocupam posição central no gráfico, região também ocupados por Leste e Sudeste Asiáticos.

Na Tabela 22 é possível visualizar as Distâncias de Mahalanobis realizadas sobre grandes regiões geográficas. As populações mais próximas dos paleoíndios de Lagoa Santa são as populações da América Central e do Sul e as do Nordeste, Sudeste e Oeste Asitáticos, e as mais distantes são as australianas e africanas subsaarianas.

De acordo com os Índices Cofenéticos da Tabela 20 somente os dendrogramas gerados pelo método de ligação pela média não ponderada e pelo método de Ward são apresentados. Tanto os dendrogramas produzidos pela média não ponderada, quanto os produzidos pelo método de Ward para as grandes regiões geográficas (Figura 37 e Figura 38, respectivamente) colocam a população de Lagoa Santa como outlier. As demais populações seguem lógica geográfica. Uma das duas maiores diferenças entre os dois dendrogramas é a posição dos australianos que no método de ligação pela média não-ponderada é outlier e no método de Ward junta-se à populações nativas americanas. A outra grande diferença é a posição das populações da África Sub-saariana que ora é grupo irmão das populações asiáticas, polinésicas, melanésicas e européias (ligação pela média não-ponderada) e ora, grupo irmão das populações melanésicas e polinésicas apenas (Ward).

A análise de Escalonamento Multidimensional sobre a Matriz de Distâncias de Mahalanobis para dados de somente forma (Figura 39) confirma a posição 
Tabela 22 - Matriz de Distâncias de Mahalanobis (populações agrupadas por grandes regiões geográficas). Parcela masculina, somente forma (73 populações, 32 variáveis).

\begin{tabular}{|c|c|c|c|c|c|c|c|c|c|c|c|c|c|c|c|c|}
\hline & Arctic & Australia & $\begin{array}{c}\mathrm{C} / \mathrm{S} \\
\text { America }\end{array}$ & E Asia & Europe & L Sta & Melanesia & Micronesia & N Africa & $\begin{array}{c}\mathrm{N} \\
\text { America }\end{array}$ & NE Asia & Polinesia & $\begin{array}{c}\text { S } \\
\text { Asia }\end{array}$ & $\begin{array}{c}\text { SE } \\
\text { Asia }\end{array}$ & SS Africa & $\begin{array}{c}\text { W } \\
\text { Asia }\end{array}$ \\
\hline Arctic & 0 & & & & & & & & & & & & & & & \\
\hline Australia & 8,384 & 0 & & & & & & & & & & & & & & \\
\hline $\mathrm{C} / \mathrm{S}$ America & 2,180 & 7,708 & 0 & & & & & & & & & & & & & \\
\hline E Asia & 3,498 & 5,909 & 2,369 & 0 & & & & & & & & & & & & \\
\hline Europe & 5,129 & 5,072 & 4,268 & 3,136 & 0 & & & & & & & & & & & \\
\hline L Sta & 13,652 & 14,222 & 10,836 & 11,900 & 12,924 & 0 & & & & & & & & & & \\
\hline Melanesia & 5,034 & 5,993 & 3,830 & 2,532 & 2,515 & 12,347 & 0 & & & & & & & & & \\
\hline Micronesia & 7,839 & 10,980 & 5,156 & 5,067 & 6,095 & 13,320 & 4,474 & 0 & & & & & & & & \\
\hline N Africa & 7,250 & 6,304 & 5,487 & 4,563 & 2,811 & 12,208 & 3,994 & 7,196 & 0 & & & & & & & \\
\hline N America & 2,263 & 6,110 & 0,984 & 2,547 & 3,855 & 12,141 & 2,867 & 6,124 & 5,602 & 0 & & & & & & \\
\hline NE Asia & 2,572 & 5,703 & 2,526 & 1,080 & 2,479 & 10,733 & 3,019 & 5,792 & 3,355 & 2,159 & 0 & & & & & \\
\hline Polinesia & 5,901 & 5,259 & 5,581 & 2,453 & 3,120 & 11,952 & 2,142 & 4,431 & 4,662 & 4,396 & 2,856 & 0 & & & & \\
\hline S Asia & 4,299 & 6,530 & 3,054 & 1,773 & 1,333 & 11,974 & 2,574 & 5,126 & 2,441 & 2,999 & 1,599 & 2,445 & 0 & & & \\
\hline SE Asia & 3,959 & 5,880 & 3,078 & 0,902 & 2,630 & 10,973 & 1,182 & 3,987 & 3,302 & 2,596 & 1,661 & 1,712 & 1,445 & 0 & & \\
\hline SS Africa & 5,540 & 6,725 & 3,133 & 2,717 & 3,375 & 13,741 & 2,851 & 4,764 & 4,395 & 3,697 & 3,601 & 2,658 & 1,825 & 1,796 & 0 & \\
\hline W Asia & 4,867 & 4,440 & 4,007 & 3,217 & 1,011 & 10,780 & 2,365 & 6,121 & 2,316 & 3,972 & 2,445 & 2,412 & 1,534 & 2,048 & 3,361 & 0 \\
\hline
\end{tabular}




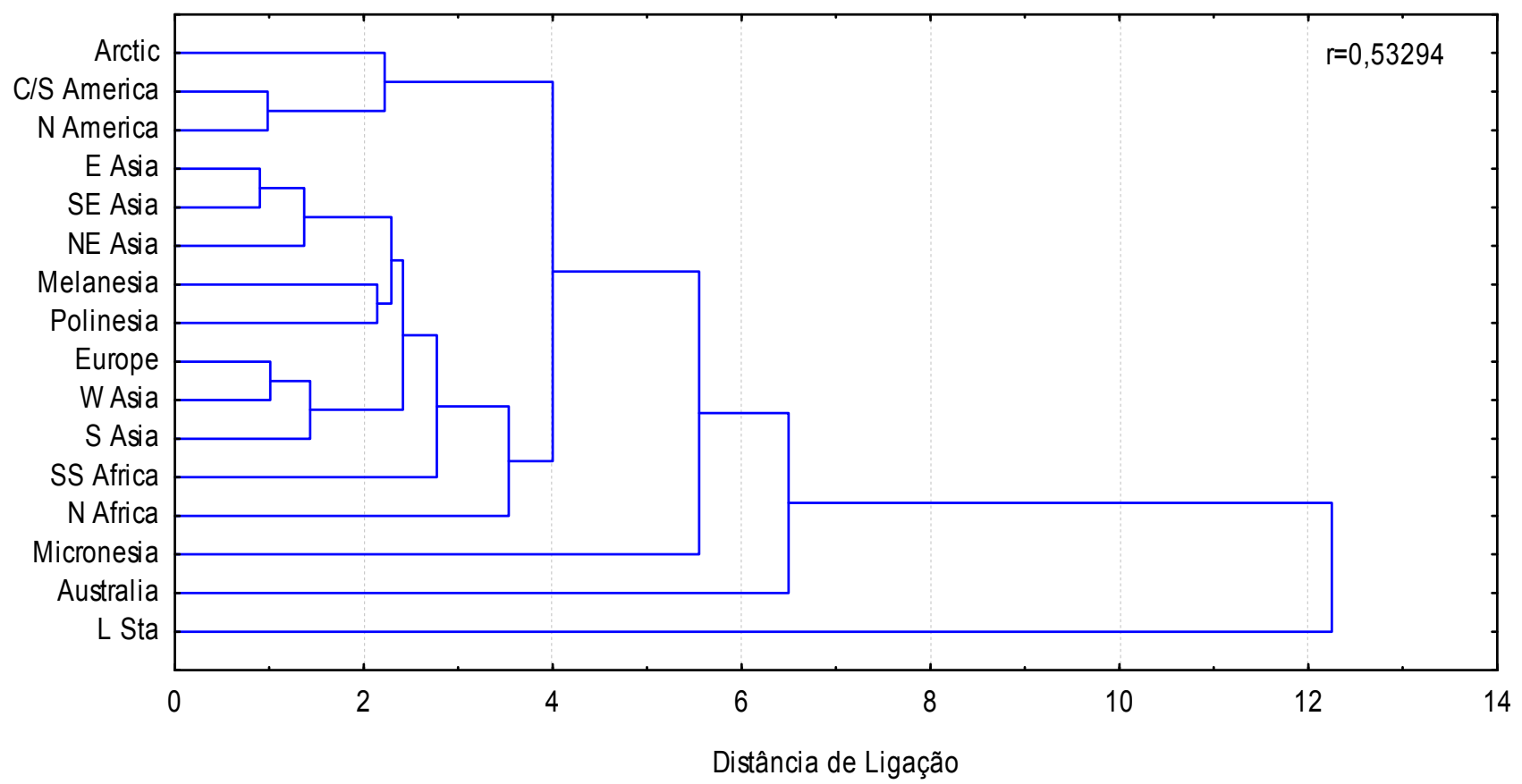

Figura 37 - Dendrograma produzido pelo critério de ligação pela Média não-ponderada sobre a matriz de Distâncias de Mahalanobis (com as populações agrupadas por grandes grupos). Parcela masculina, somente forma.

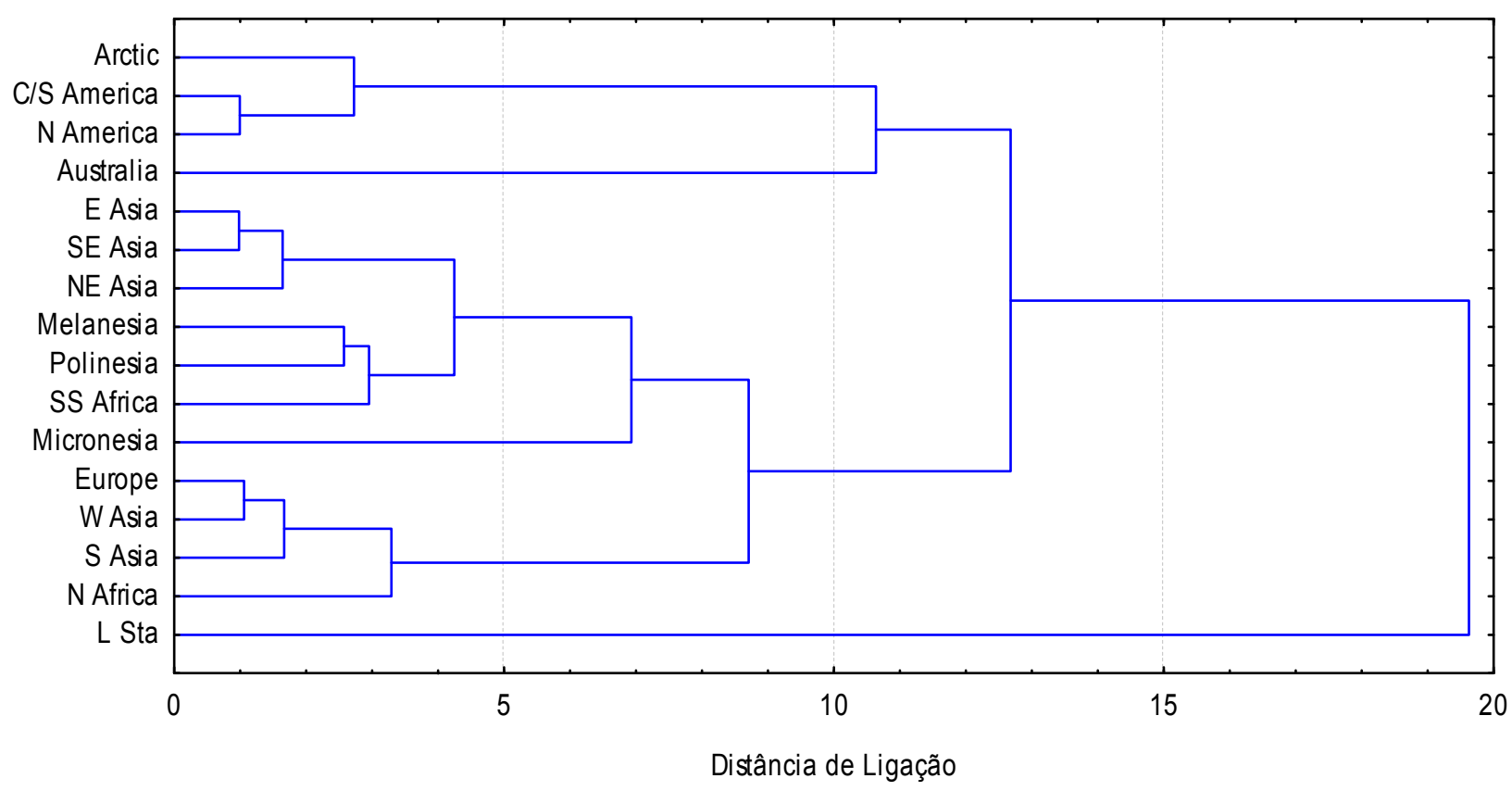

Figura 38 - Dendrograma produzido pelo critério de ligação de Ward sobre a matriz de Distâncias de Mahalanobis (com as populações agrupadas por grandes grupos). Parcela masculina, somente forma. 
outlier da população de Lagoa Santa o que não permite explorar suas afinidades com as demais populações, objetivo central deste trabalho. Em posição de outlier também estão as populações da Micronésia e da Austrália. As demais populações associam-se da seguinte forma: as populações nativas americanas estão próximas das populações do Ártico; as populações peri-mediterrânicas - européias, norteaffricanas e do Oriente Médio - mais uma vez encontram-se associadas; e, todas as populações asiáticas estão posicionadas próximas entre si na parte central do gráfico tridimensional. A população mais próxima dos paleoíndios de Lagoa Santa são as populações polinésicas, que por si, estão mais próximas das melanésicas.

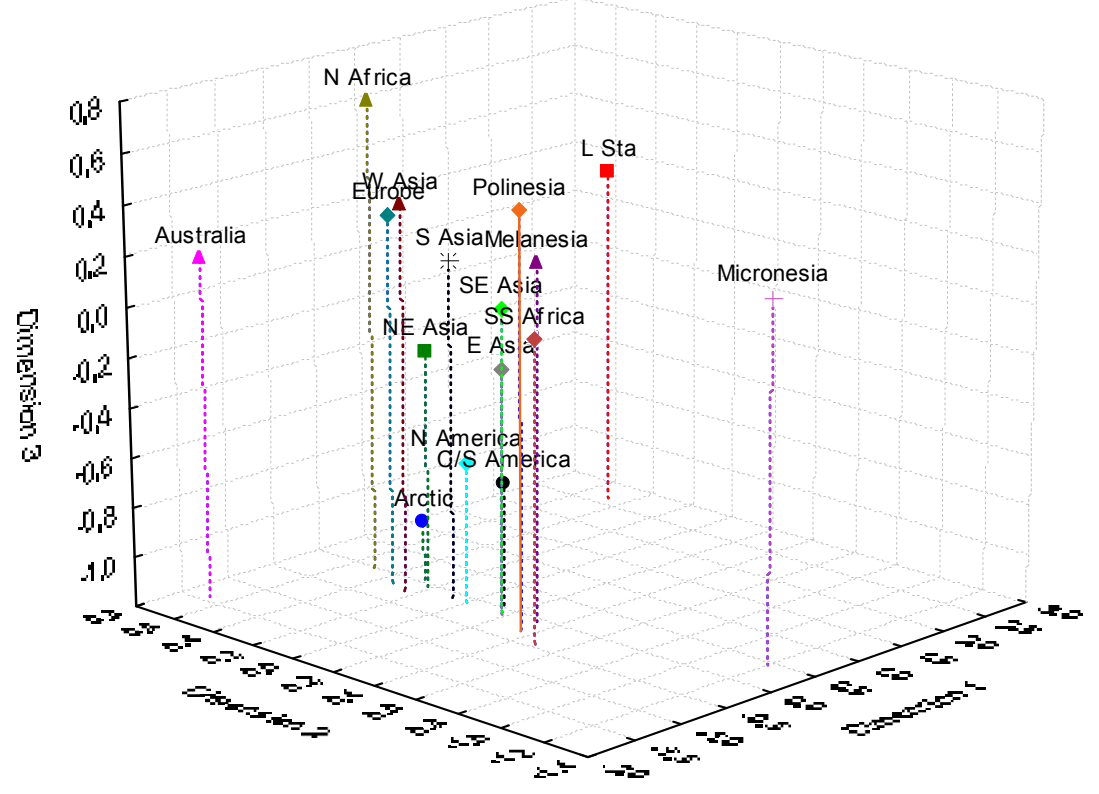

Figura 39 - Gráfico tridimensional produzido pela Análise de Escalonamento Multidimensional sobre a matriz de Distâncias de Mahalanobis (com as populações agrupadas por grandes regiões geográficas). Parcela masculina, somente forma). 
A Tabela 23 apresenta os autovalores dos onze primeiros componentes principais gerados para a parcela feminina com base nos dados brutos, ou seja, levando-se em consideração tamanho e forma. Novamente, é possível observar uma grande discrepância em termos de variância explicada pelo Primeiro Componente Principal (64\%) em relação aos demais. Tal valor confirma o fator "tamanho" dos dentes. Os demais componentes principais explicam pouco da variância observada entre as populações, com o segundo componete explicando menos que $10 \%$ dessa variância $(C P 2=8,34 \%)$. O decaimento dos valores de representatividade dos componentes é também apresentado na Figura 40, e uma queda abrupta é observada após do Primeiro Componente.

Tabela 23 - Autovalores e percentagens de variância explicada pelos primeiros onze componentes principais. Parcela feminina, tamanho e forma (43 populações, 32 variáveis).

\begin{tabular}{ccccc}
\hline $\begin{array}{c}\text { Componente } \\
\text { Principal }\end{array}$ & Autovalor & $\begin{array}{c}\text { \% Total de Variância } \\
\text { Explicada }\end{array}$ & $\begin{array}{c}\text { Autovalor } \\
\text { Cumulativo }\end{array}$ & $\begin{array}{c}\% \\
\text { Cumulativa }\end{array}$ \\
\hline \hline 1 & 2,426848 & 64,16436 & 2,426848 & 64,1644 \\
2 & 0,315616 & 8,34470 & 2,742464 & 72,5091 \\
3 & 0,177645 & 4,69684 & 2,920109 & 77,2059 \\
4 & 0,127296 & 3,36562 & 3,047405 & 80,5715 \\
5 & 0,121396 & 3,20962 & 3,168801 & 83,7811 \\
6 & 0,100311 & 2,65215 & 3,269112 & 86,4333 \\
7 & 0,091139 & 2,40965 & 3,360250 & 88,8430 \\
8 & 0,074655 & 1,97382 & 3,434905 & 90,8168 \\
9 & 0,056326 & 1,48923 & 3,491231 & 92,3060 \\
10 & 0,043442 & 1,14858 & 3,534673 & 93,4546 \\
11 & 0,038973 & 1,03043 & 3,573646 & 94,4850 \\
\hline
\end{tabular}

De acordo com a Tabela 24 o Primeiro Componente extraído dos dados brutos, ou seja, tamanho e forma, apresenta-se altamente correlacionado com todas as variáveis de forma negativa (a visualização gráfica na Figura 41). Isto, 
mais uma vez, reafirma que o Primeiro Componente é definido essencialmente pelo fator "tamanho". Portanto, todas as populações que estão na porção esquerda do Figura 42 são aquelas com os maiores dentes, e vice-versa.

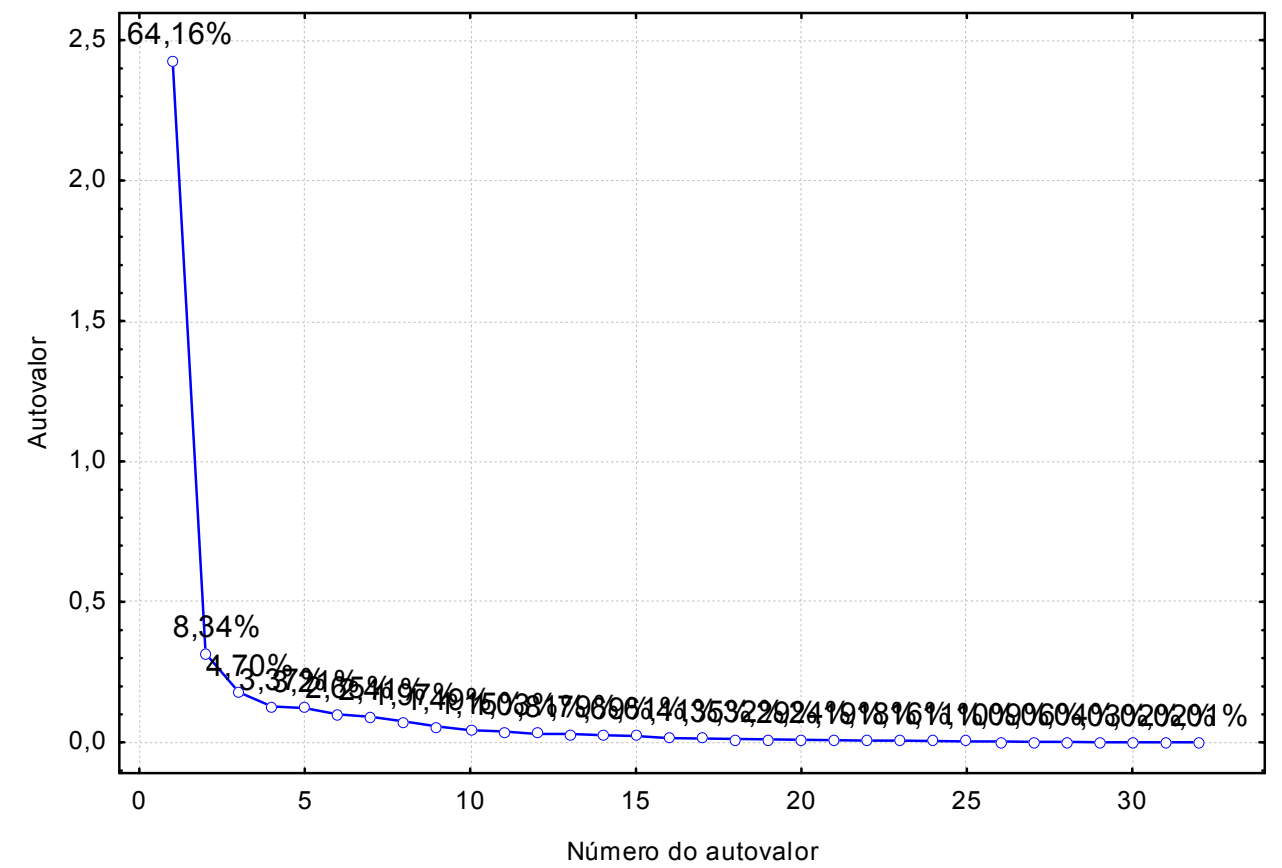

Figura 40 - Screeplot representando o decaimento das porcentagens de variância explicadas por cada componente principal. Parcela Feminina, tamanho e forma (43 populações, 32 variáveis).

Quando são observadas as correlações das variáveis originais com o Segundo Componente, as relações existentes são distintas (Tabela 24). Praticamente todas as variáveis referentes aos diâmetros mesiodistais estabelecem correlações positivas com o Segundo Componente, com a excessão dos dentes inferiores incisivos centrais e primeiros e segundos pré-molares. Entretanto, essas exceções são de magnitude extremamente baixas, variando de $-0,183$ a $-0,001$, permitindo então, considerar que o Segundo Componente Principal se correlaciona positivamente com os diâmetros mesiodistais. No que diz respeito aos diâmetros 
bucolinguais, a relação é inversa, ou seja, os diâmetros bucolinguais relacionam-se negativamente com o Segundo Componente. Novamente, exceções podem ser observadas, neste caso, correlações positivas para os dentes incisivos laterais e primeiros molares superiores e para os primeiros e segundos molares inferiores estão presentes, entretanto, mais uma vez são magnitudes baixas (variando de 0,147 a 0,016). Portanto, pode-se generalizar que os diâmetros bucolinguais relacionam-se negativamente com o Segundo Componente Principal para a parcela feminina. Permitindo, consequentemente, afirmar que as populações nos quadrantes superiores da Figura 42 apresentam dentes mais lateralizados enquanto que as populações distribuídas nos quadrantes inferiores, dentes mais espessos.

Tabela 24 - Correlação entre as variáveis originais e os componentes principais extraídos. Parcela feminina, tamanho e forma (43 populações, 32 variáveis).

\begin{tabular}{lcc} 
& Fator 1 & Fator 2 \\
\hline \hline MD I1 U & $-0,709583$ & 0,259233 \\
MD I2 U & $-0,707136$ & 0,507026 \\
MD C U & $-0,862537$ & 0,294911 \\
MD PM1 U & $-0,874953$ & 0,089176 \\
MD PM2 U & $-0,865771$ & 0,226413 \\
MD M1 U & $-0,881011$ & 0,297494 \\
MD M2 U & $-0,927265$ & 0,185995 \\
MD M3 U & $-0,664353$ & 0,001404 \\
MD I1 L & $-0,729504$ & $-0,080550$ \\
MD I2 L & $-0,835109$ & 0,200809 \\
MD C L & $-0,836525$ & 0,109832 \\
MD PM1 L & $-0,819518$ & $-0,183035$ \\
MD PM2 L & $-0,853105$ & $-0,001891$ \\
MD M1 L & $-0,885358$ & 0,159306
\end{tabular}


(Continuação) Tabela 24 - Correlação entre as variáveis originais e os componentes principais extraídos. Parcela feminina, tamanho e forma (43 populações, 32 variáveis)

\begin{tabular}{lcc}
\hline & Fator 1 & Fator 2 \\
\hline \hline MD M2 L & $\underline{-0,922322}$ & 0,118121 \\
MD M3 L & $-0,765996$ & 0,218191 \\
BL I1 U & $-0,673043$ & $-0,157933$ \\
BL I2 U & $-0,706677$ & 0,097447 \\
BL C U & $-0,851783$ & $-0,309952$ \\
BL PM1 U & $-0,856598$ & $-0,350483$ \\
BL PM2 U & $-0,839831$ & $-0,260898$ \\
BL M1 U & $-0,902586$ & 0,044310 \\
BL M2 U & $-0,894551$ & $-0,158591$ \\
BL M3 U & $-0,727496$ & $-0,375717$ \\
BL I1 L & $-0,332688$ & $-0,602101$ \\
BL I2 L & $-0,442658$ & $-0,511876$ \\
BL C L & $-0,594293$ & $-0,505437$ \\
BL PM1 L & $-0,694852$ & $-0,650970$ \\
BL PM2 L & $-0,687087$ & $-0,433942$ \\
BL M1 L & $-0,803651$ & 0,147867 \\
BL M2 L & $-0,894170$ & 0,016686 \\
BL M3 L & $-0,853210$ & $-0,010223$ \\
\hline
\end{tabular}

* destaque em vermelho para as correlações maiores que 0,5 , sublinhado para as correlações maiores que 0,9.

A projeção das variáveis originais e os dois primeiros componentes principais é apresentada na Figura 41. Destaque deve ser dado ao fato de todas as projeções seguirem uma mesma direção, ou seja, a dispersão das populações no morfo-espaço da Figura 42 deve-se, quase que completamente, ao tamanho dentário. A distribuição das projeções das variáveis na Figura 41 é mais difusa do que observado para a parcela masculina, tamanho e forma (Figura 23), no entanto ainda é possível observar uma setorização das projeções dos grupos dentários com os dentes anteriores (incisivos e caninos) localizados na porção mais a direita do gráfico, os dentes pré-molares, na porção mais inferior central enquanto os 
molares na porção mais superior esquerda.

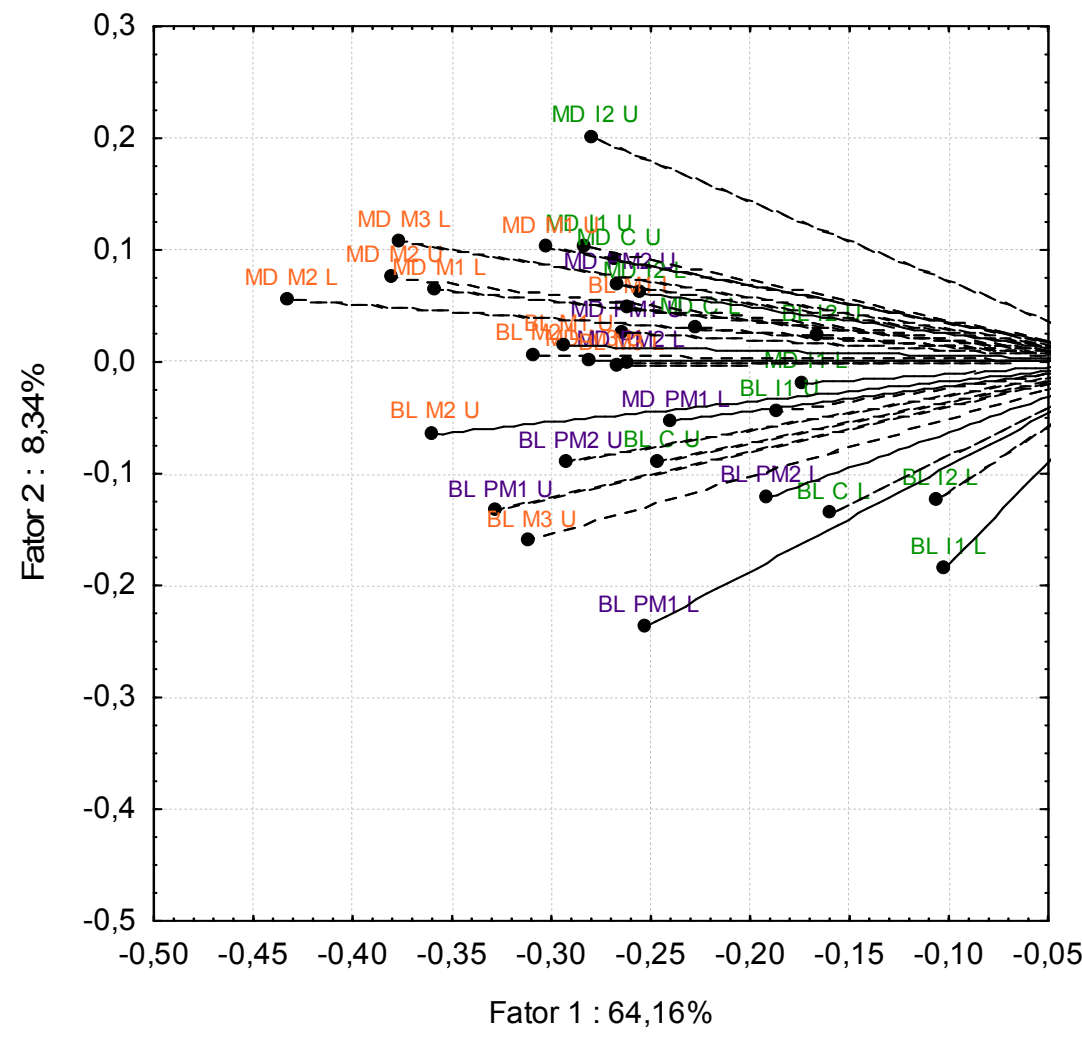

Figura 41 - Projeção das variáveis no morfo-espaço definido pelos dois primeiros Componentes Principais. Parcela feminina, tamanho e forma (43 populações, 32 variáveis).

O gráfico do morfo-espaço formado pelos dois primeiros componentes principais na Figura 42 separa destacadamente as populações australomelanésicas das demais populações analisadas, com os maiores dentes entre todas as populações humanas do planeta e com dentes mais espessos, ou seja, extremamente robustos em ambos os diâmetros. Em posição diametralmente oposta encontram-se as populações européias e do Leste Asiático com os menores dentes e mais lateralizados. Populações do Sudeste Asiático e polinésicas 


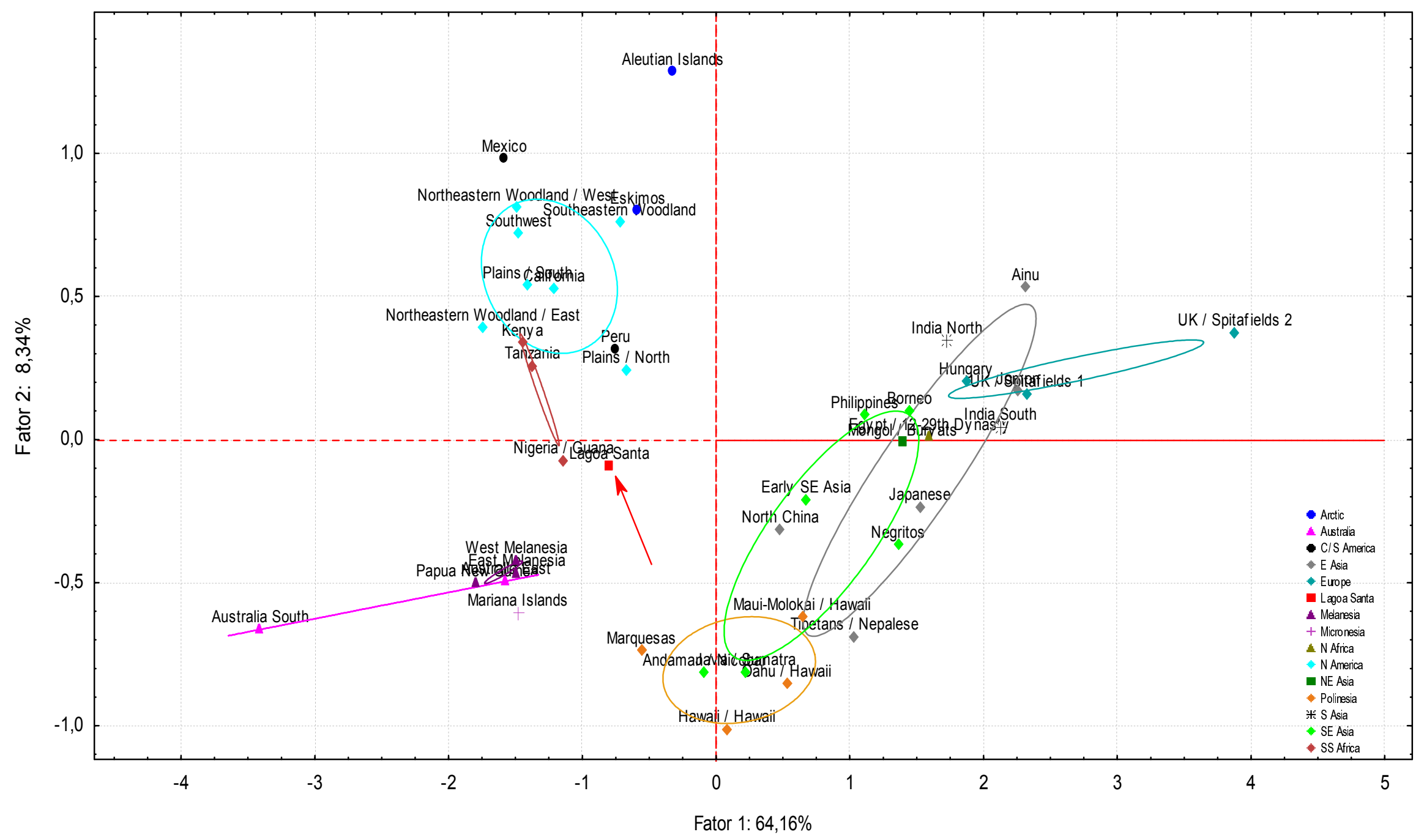

Figura 42 - Morfo-espaço formado pelos $1^{\circ}$ e $2^{\circ}$ componentes principais. Parcela Feminina, tamanho e forma (43 populações, 32 variáveis) 
encontram-se muito próximas às populações do Leste Asiático, também com dentes de tamanho mais reduzido, no entanto com dentes mais espessos. Outro conjunto populacional com distanciamento considerável é formado pelo continente americano e pela África Sub-saariana com dentes de tamanho relativamente grandes próximos às populações com os maiores dentes (australianos). Entretanto, as populações americanas diferenciam-se das populações australianas por apresentarem dentes mais lateralizados, ou seja, com maiores diâmetros mesiodistais. A população de Lagoa Santa ocupa uma posição intermediária entre os conjuntos populacionais autralo-melanésico, americano e euro-asiático, com dentes relativamente grandes no entanto, nem mais espessos nem mais lateralizados, já que se encontra em posição intermediária no que diz respeito à projeção do Segundo Componente Principal. Vale destacar que esta amostra Paleoíndia de Lagoa Santa, apesar de se encontrar mais próxima ao conjunto populacional americano-africano, está fora da elipse de dispersão de $95 \%$ de qualquer uma das populações analisadas e em posição intermediária entre os conjuntos américo-africano, australomelanésico e sudeste asiático-polinésico.

Por razões óbvias as análises de Cluster subseqüentes foram realizadas somente com os três primeiros componentes princiapais. A Tabela 25 apresenta os Índices Cofenéticos dos diferentes critérios de agregação (ligação simples, composta, ponderada pela média e não-ponderada pela média). Como já dito, o método de Ward de agregação não pode ser validado pelo Índice Cofenético por questões computacionais.

Apesar de nenhum dos valores dos índices cofenéticos estarem de 
acordo com o valor mínimo esperado $(r=0,70)$, o dendrograma obtido pelo método com o melhor resultado, a ligação pela média não-ponderada e o dendrograma obtido pelo método de Ward's (não validado) serão apresentados pelo relaxamento do critério para valores maiores que 0,4 (Figuras 43 e 44, respectivamente).

Tabela 25 - Índices Cofenéticos para os diferentes critérios de "clustering" a partir de Distâncias Euclidianas. Parcela feminina, tamanho e forma (43 populações, 32 variáveis).

\begin{tabular}{lc}
\hline Método de Agregação & Índice Cofenético $-\mathrm{r}$ \\
\hline \hline Simples & 0,18152 \\
Composta & 0,23248 \\
média não ponderada & $\mathbf{0 , 4 2 5 4 7}$ \\
média ponderada & 0,37756 \\
\hline
\end{tabular}

No dendrograma apresentado na Figura 43 por ligação pela média não ponderada, na distância de ligação ao redor de 2 unidades é possível observar a formação de quatro grandes grupos: um primeiro, americano; um segundo, composto primordialmente por populações Australo-melanesicas; um terceiro, composto por populações européias, Leste e Sul Asiáticas; e um quarto, composto por populações com posições atípicas. As populações do Leste e Sudeste Asiáticos bem como as populações polinésicas estão dispersas no segundo, terceiro e quatro grupos. A população de Lagoa Santa está inserida no cluster formado pelas populações nativas americanas.

No dendrograma da Figura 44 gerado pelo método de Ward, na distância de amalgama de aproximadamente 8,0 é possível visualizar quatro agrupamentos principais. Novamente, um primeiro agrupamento é composto pelas populações nativas americanas, um segundo agrupamento pelas 
populações autralo-melanésicas e africanas, um terceiro grupo, pelas populações européias, Sul e Leste Asiáticas, e um quarto, composto principalmente por populações do Sudeste Asiático. As populações polinésicas estão distribuídas no terceiro e quarto agrupamentos. Já a população de Lagoa Santa encontra-se associada as nativas americanas.

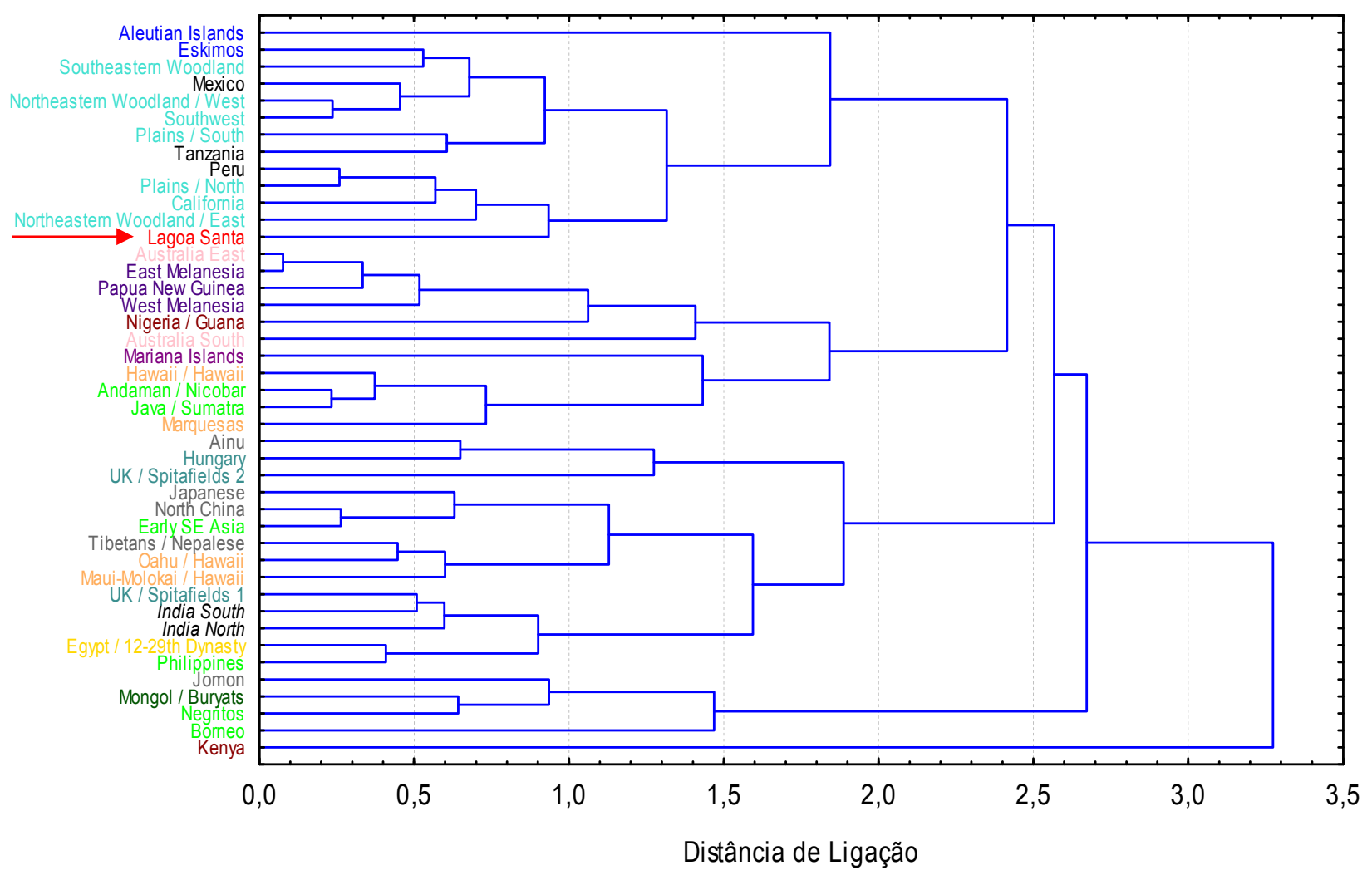

Figura 43 - Dendrograma produzido pelo critério de ligação por média não-ponderada a partir dois três primeiros componentes principais (Distâncias Euclidianas). Parcela feminina, tamanho e forma.

As matrizes de Distâncias de Mahalanobis da parcela feminina (tamanho e forma) foram produzidas para dois níveis de agregação, o populacional e por grandes regiões geográficos (classificação apresentada na Tabela 02). Nenhum valores dos Índices Cofenéticos, nem para o agrupamento populacional nem para grandes regiões geográficas, sequer supera o relaxamento do critério de exclusão e portanto nenhum dendrograma será gerado (Tabela 26). 
As matrizes de Distancias de Mahalanobis e gráficos de Escalonamento Multidimensional gerados sobre as matrizes de Distâncias de Mahalanobis para ambos os níveis de agrupamento são apresentadas nas Tabelas 27 e 28 e Figura 42 e 43, respectivamente. A matriz de Distâncias de Mahalanobis no

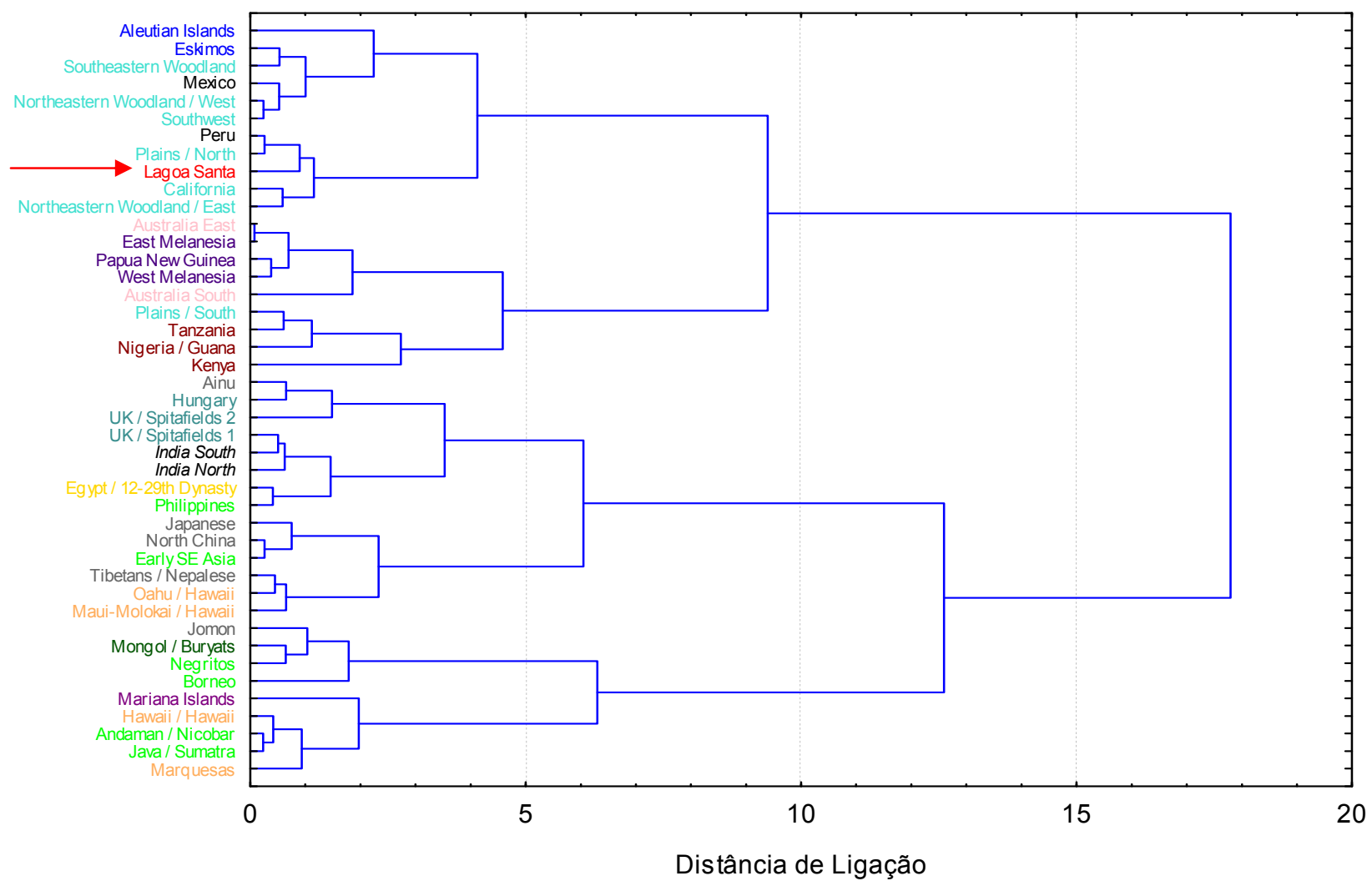

Figura 44 - Dendrograma produzido pelo critério de Ward a partir dois três primeiros componentes principais (Distâncias Euclidianas). Parcela feminina, tamanho e forma.

Tabela 26 - Índices Cofenéticos para os diferentes critérios de "clustering" a partir de Distâncias de Mahalanobis. Parcela feminina, tamanho e forma (43 populações, 32 variávies).

\begin{tabular}{llc}
\hline Classificação & Método de Agregação & Índice Cofenético - r \\
\hline \hline Populacional & Simples & 0,20123 \\
Populacional & Composta & 0,23946 \\
Populacional & média não ponderada & 0,34209 \\
Populacional & média ponderada & $\mathbf{0 , 3 7 0 2 4}$ \\
Grandes regiões & Simples & 0,18536 \\
Grandes regiões & Composta & 0,27549 \\
Grandes regiões & média não ponderada & $\mathbf{0 , 3 2 8 3 9}$ \\
Grandes regiões & média ponderada & 0,311432 \\
\hline
\end{tabular}


Tabela 27 - Matriz de Distancias de Mahalanobis (agrupamento realizado por populações locais). Parcela feminina, tamanho e forma (43 populações, 32 variáveis).

\begin{tabular}{|c|c|c|c|c|c|c|c|c|c|c|c|c|c|c|c|c|c|c|c|c|c|c|c|c|c|}
\hline & $\begin{array}{l}\text { Egypt / 12- } \\
29 t h \text { Dyn } \\
\end{array}$ & Kenya & $\begin{array}{c}\text { Nigeria/ } \\
\text { Guanana } \\
\end{array}$ & Tanzania & $\begin{array}{c}\text { Aleutian } \\
\text { Isl } \\
\end{array}$ & $\begin{array}{l}\text { Eskimos } \\
\end{array}$ & Mexico & Peru & $\begin{array}{l}\text { California } \\
\end{array}$ & $\begin{array}{c}\text { NE Woodland } \\
/ \mathrm{E} \\
\end{array}$ & $\begin{array}{c}\text { NE Woodland / } \\
\mathrm{W}\end{array}$ & Plains $/ \mathrm{N}$ & Plains $/ \mathrm{s}$ & $\begin{array}{c}\text { SE } \\
\text { Woodland }\end{array}$ & $\begin{array}{l}\text { Southwest } \\
\end{array}$ & LSta & Ainu & $\begin{array}{l}\text { Japanese } \\
\end{array}$ & Jomon & NChina & $\begin{array}{l}\text { Tibetans/ } \\
\text { Nepalese } \\
\end{array}$ & $\begin{array}{c}\text { Mongol/ } \\
\text { Burrats } \\
\end{array}$ & India N & Indias & $\begin{array}{l}\text { Andaman } \\
\text { / Nicobar } \\
\end{array}$ \\
\hline Egypt / 12-29th Dyn & 0 & & & & & & & & & & & & & & & & & & & & & & & & \\
\hline Kenya & 10,471 & 0 & & & & & & & & & & & & & & & & & & & & & & & \\
\hline Nigeria / Guana & 10,497 & 8,055 & 0 & & & & & & & & & & & & & & & & & & & & & & \\
\hline Tanzania & 11,124 & 8,562 & 7,227 & 0 & & & & & & & & & & & & & & & & & & & & & \\
\hline Aleutian isl & 10,717 & 12,203 & 9,596 & 10,615 & 0 & & & & & & & & & & & & & & & & & & & & \\
\hline Eskimos & 8,437 & 11,362 & 10,619 & 7,824 & 4,285 & 0 & & & & & & & & & & & & & & & & & & & \\
\hline Mexico & 15,886 & 12,550 & 13,730 & 11,899 & 8,585 & 9,037 & 0 & & & & & & & & & & & & & & & & & & \\
\hline Peru & 9,376 & 10,191 & 8,369 & 6,616 & 8,842 & 4,429 & 6,355 & 0 & & & & & & & & & & & & & & & & & \\
\hline California & 11,865 & 11,538 & 8,008 & 6,612 & 5,744 & 3,991 & 8,152 & 6,211 & 0 & & & & & & & & & & & & & & & & \\
\hline NE Woodland / E & 7,565 & 9,416 & 8,181 & 7,619 & 4,948 & 4,820 & 7,756 & 5,013 & 5,221 & 0 & & & & & & & & & & & & & & & \\
\hline NE Woodland / W & 9,959 & 9,884 & 8,735 & 9,448 & 6,700 & 5,581 & 7,929 & 5,782 & 5,925 & 3,011 & 0 & & & & & & & & & & & & & & \\
\hline Plains $/ \mathrm{N}$ & 8,169 & 10,408 & 7,514 & 4,291 & 5,527 & 3,107 & 8,580 & 2,912 & 3,080 & 3,596 & 5,309 & 0 & & & & & & & & & & & & & \\
\hline Plains $/ \mathrm{s}$ & 7,254 & 7,783 & 5,791 & 5,388 & 6,559 & 4,469 & 7,029 & 3,261 & 5,363 & 3,230 & 3,337 & 3,709 & 0 & & & & & & & & & & & & \\
\hline SE Woodland & 7,586 & 7,772 & 8,815 & 8,063 & 6,179 & 4,083 & 8,411 & 4,486 & 4,977 & 2,572 & 2,793 & 4,161 & 3,596 & 0 & & & & & & & & & & & \\
\hline Southwest & 7,186 & 7,921 & 7,475 & 6,565 & 4,401 & 4,123 & 6,573 & 3,872 & 6,607 & 3,865 & 6,510 & 4,333 & 4,095 & 4,949 & 0 & & & & & & & & & & \\
\hline L Sta & 16,545 & 16,564 & 13,039 & 19,887 & 16,875 & 15,612 & 21,300 & 15,177 & 15,018 & 14,841 & 14,215 & 12,927 & 14,587 & 14,054 & 16,236 & 0 & & & & & & & & & \\
\hline Ainu & 7,293 & 10,456 & 9,878 & 9,259 & 6,327 & 2,973 & 11,868 & 6,424 & 6,085 & 6,869 & 6,568 & 4,991 & 6,104 & 5,387 & 6,373 & 14,331 & 0 & & & & & & & & \\
\hline Japanese & 10,352 & 16,786 & 15,664 & 16,774 & 13,190 & 11,421 & 14,439 & 13,194 & 10,868 & 11,194 & 11,415 & 10,261 & 11,740 & 12,203 & 13,198 & 19,087 & 8,735 & 0 & & & & & & & \\
\hline Jomon & 8,583 & 13,667 & 10,750 & 11,841 & 9,039 & 5,076 & 13,733 & 8,242 & 7,224 & 8,404 & 9,001 & 6,162 & 7,671 & 7,896 & 7,608 & 15,821 & 2,955 & 11,300 & 0 & & & & & & \\
\hline N China & 14,387 & 19,476 & 13,661 & 12,822 & 16,272 & 13,232 & 24,538 & 16,149 & 15,120 & 13,415 & 19,678 & 13,292 & 14,512 & 15,386 & 13,476 & 27,915 & 14,633 & 25,536 & 13,787 & 0 & & & & & \\
\hline Tibetans / Nepalese & 27,074 & 30,886 & 28,623 & 30,738 & 30,508 & 23,691 & 28,288 & 23,570 & 27,619 & 24,820 & 31,479 & 23,693 & 24,685 & 25,856 & 23,053 & 40,665 & 25,339 & 35,297 & 18,301 & 19,794 & 0 & & & & \\
\hline Mongol / Buryats & 6,065 & 9,571 & 7,661 & 8,687 & 6,319 & 3,846 & 10,717 & 6,813 & 4,460 & 4,929 & 6,577 & 4,232 & 5,632 & 6,379 & 5,144 & 13,423 & 3,427 & 7,232 & 3,678 & 14,879 & 24,749 & 0 & & & \\
\hline India N & 7,091 & 9,154 & 9,148 & 6,956 & 9,720 & 6,982 & 12,087 & 7,961 & 6,635 & 7,923 & 8,314 & 6,584 & 7,415 & 5,932 & 7,505 & 16,284 & 5,331 & 9,022 & 8,193 & 17,083 & 32,351 & 5,530 & 0 & & \\
\hline India S & 9,918 & 9,595 & 11,678 & 12,660 & 10,772 & 9,097 & 11,900 & 8,665 & 12,288 & 9,828 & 12,747 & 9,273 & 8,577 & 9,651 & 8,888 & 17,745 & 7,263 & 10,125 & 9,771 & 17,642 & 24,623 & 7,587 & 8,855 & 0 & \\
\hline Andaman / Nicobar & 7,737 & 11,028 & 7,488 & 8,041 & 10,001 & 6,961 & 16,773 & 8,189 & 6,636 & 6,417 & 8,165 & 4,829 & 6,041 & 8,235 & 10,113 & 12,966 & 5,605 & 12,477 & 7,329 & 13,055 & 29,762 & 4,363 & 7,829 & 11,042 & 0 \\
\hline Borneo & 13,999 & 15,397 & 15,280 & 17,774 & 11,433 & 10,681 & 16,139 & 12,536 & 14,086 & 10,038 & 11,717 & 12,127 & 12,951 & 11,812 & 11,908 & 19,624 & 7,117 & 11,805 & 8,051 & 20,525 & 31,596 & 7,530 & 9,885 & 9,421 & 10,740 \\
\hline Early SE Asia & 10,282 & 13,916 & 9,959 & 10,077 & 9,011 & 6,405 & 11,574 & 8,043 & 6,253 & 6,510 & 7,111 & 7,144 & 8,012 & 7,477 & 8,477 & 19,147 & 5,151 & 10,419 & 7,743 & 15,793 & 32,368 & 4,932 & 5,992 & 12,102 & 5,787 \\
\hline Java / Sumatra & 15,406 & 18,612 & 11,509 & 15,424 & 16,559 & 14,793 & 17,304 & 14,856 & 13,708 & 15,695 & 18,271 & 12,575 & 14,651 & 17,742 & 14,710 & 20,791 & 13,832 & 11,490 & 11,974 & 15,811 & 25,764 & 12,317 & 13,807 & 12,435 & 14,141 \\
\hline Negritos & 13,291 & 16,676 & 13,271 & 13,095 & 16,466 & 11,344 & 15,529 & 11,415 & 11,274 & 10,931 & 11,777 & 9,621 & 10,727 & 11,255 & 12,425 & 18,997 & 9,839 & 8,081 & 10,294 & 21,256 & 29,090 & 8,421 & 8,389 & 14,768 & 11,413 \\
\hline Philippines & 7,926 & 7,800 & 7,112 & 7,310 & 10,177 & 6,932 & 9,401 & 6,243 & 6,558 & 8,049 & 7,091 & 5,663 & 4,697 & 6,237 & 7,226 & 16,950 & 5,411 & 13,110 & 6,142 & 16,161 & 22,883 & 5,148 & 5,065 & 8,926 & 6,035 \\
\hline Hungary & 4,452 & 9,834 & 9,022 & 9,291 & 9,100 & 7,013 & 14,046 & 7,453 & 8,625 & 7,512 & 9,497 & 5,907 & 6,956 & 6,985 & 6,413 & 14,708 & 4,988 & 10,255 & 5,495 & 15,058 & 26,310 & 4,108 & 4,991 & 6,325 & 6,576 \\
\hline UK/ spit 1 & 6,209 & 8,261 & 7,694 & 10,458 & 9,049 & 7,093 & 12,960 & 9,319 & 6,671 & 6,917 & 8,696 & 7,166 & 7,424 & 5,705 & 9,027 & 14,913 & 4,880 & 8,069 & 6,125 & 14,031 & 23,415 & 4,375 & 5,041 & 6,784 & 6,618 \\
\hline UK / spit 2 & 6,413 & 15,159 & 15,728 & 13,357 & 11,670 & 11,111 & 20,378 & 15,095 & 11,434 & 11,792 & 15,489 & 11,051 & 13,167 & 9,920 & 12,248 & 20,567 & 8,400 & 14,719 & 11,357 & 19,192 & 35,510 & 9,139 & 7,576 & 14,395 & 9,871 \\
\hline Australia E & 14,910 & 12,125 & 14,041 & 10,800 & 12,772 & 6,999 & 15,498 & 11,151 & 6,066 & 9,077 & 11,400 & 7,444 & 11,038 & 9,149 & 11,283 & 18,737 & 9,608 & 12,781 & 11,267 & 15,591 & 27,731 & 7,728 & 12,362 & 14,244 & 9,035 \\
\hline Australia S & 15,689 & 12,693 & 14,165 & 9,604 & 14,407 & 9,016 & 15,984 & 12,192 & 8,971 & 8,456 & 11,887 & 7,356 & 11,511 & 9,656 & 12,259 & 19,731 & 12,474 & 16,438 & 12,095 & 16,169 & 25,254 & 9,619 & 13,814 & 14,845 & 10,389 \\
\hline E Melanesia & 8,776 & 8,761 & 5,127 & 7,316 & 9,230 & 6,594 & 10,765 & 5,390 & 6,756 & 5,514 & 6,359 & 5,108 & 3,886 & 6,565 & 5,866 & 15,818 & 6,240 & 11,223 & 8,668 & 15,643 & 24,314 & 5,397 & 8,502 & 10,152 & 5,923 \\
\hline Papua New Guinea & 10,807 & 8,116 & 7,297 & 7,733 & 9,517 & 8,089 & 12,970 & 8,810 & 5,848 & 5,815 & 8,691 & 5,848 & 7,630 & 5,662 & 8,111 & 12,805 & 8,785 & 14,739 & 11,367 & 14,473 & 26,550 & 7,763 & 7,585 & 10,183 & 6,515 \\
\hline w Melanesia & 5,692 & 7,214 & 5,692 & 6,070 & 8,077 & 5,156 & 8,646 & 4,452 & 5,226 & 2,970 & 4,724 & 4,090 & 3,067 & 3,806 & 3,887 & 15,219 & 6,204 & 10,837 & 7,086 & 13,721 & 22,011 & 3,974 & 5,770 & 9,553 & 5,145 \\
\hline Mariana Isl & 15,575 & 11,939 & 9,815 & 15,448 & 11,750 & 10,469 & 12,273 & 10,000 & 8,494 & 10,194 & 10,082 & 9,296 & 9,509 & 10,897 & 10,679 & 15,528 & 11,371 & 16,216 & 10,393 & 21,333 & 26,864 & 8,545 & 13,316 & 15,441 & 9,698 \\
\hline Hawaii / Hawaii & 8,350 & 10,565 & 6,478 & 10,300 & 9,474 & 7,701 & 13,181 & 8,278 & 7,653 & 5,096 & 8,011 & 6,325 & 7,334 & 7,244 & 6,976 & 14,250 & 6,180 & 8,664 & 7,541 & 13,448 & 22,362 & 4,221 & 8,123 & 8,140 & 6,239 \\
\hline Marquesas & 9,137 & 9,055 & 8,812 & 10,642 & 10,977 & 7,656 & 12,117 & 7,040 & 8,751 & 7,676 & 10,513 & 6,650 & 8,577 & 8,846 & 7,936 & 14,446 & 8,653 & 12,186 & 10,123 & 17,828 & 25,572 & 5,656 & 9,523 & 7,291 & 7,374 \\
\hline Maui-Molokai / Hawaii & 7,203 & 10,860 & 7,471 & 9,906 & 8,892 & 6,084 & 13,140 & 7,874 & 6,785 & 5,246 & 6,007 & 5,543 & 7,190 & 5,764 & 8,011 & 14,907 & 4,548 & 8,342 & 5,994 & 15,241 & 25,605 & 3,747 & 5,916 & 9,152 & 4,390 \\
\hline Oahu / Hawaii & 8,920 & 8,414 & 8,504 & 10,105 & 10,289 & 7,387 & 12,395 & 7,027 & 6,911 & 6,450 & 7,839 & 5,474 & 7,646 & 6,803 & 7,590 & 15,085 & 5,946 & 8,853 & 7,695 & 16,667 & 25,644 & 3,832 & 8,589 & 7,278 & 5,554 \\
\hline
\end{tabular}


(Continuação) Tabela 27 - Matriz de Distancias de Mahalanobis (agrupamento realizado por populações locais). Parcela feminina, tamanho e forma (43 populações, 32 variáveis).

\begin{tabular}{|c|c|c|}
\hline \multicolumn{3}{|l|}{ Egypt / 12-29th Dyn } \\
\hline Kenya & & \\
\hline Nigeria / Guana & & \\
\hline Tanzania & & \\
\hline Aleutian |s| & & \\
\hline Eskimos & & \\
\hline Mexico & & \\
\hline Peru & & \\
\hline California & & \\
\hline NE Woodland/E & & \\
\hline NE Woodland / W & & \\
\hline Plains / N & & \\
\hline Plains /s & & \\
\hline SE Woodland & & \\
\hline Southwest & & \\
\hline LSta & & \\
\hline Ainu & & \\
\hline Japanese & & \\
\hline Jomon & & \\
\hline N China & & \\
\hline Tibetans / Nepalese & & \\
\hline Mongol / Buryats & & \\
\hline India N & & \\
\hline India S & & \\
\hline Andaman / Nicobar & & \\
\hline Borneo & 0 & \\
\hline Early SE Asia & 9,012 & 0 \\
\hline Java / Sumatra & 14,943 & 13,154 \\
\hline Negritos & 12,664 & 8,252 \\
\hline Philippines & 13,427 & 7,580 \\
\hline Hungary & 9,819 & 9,578 \\
\hline UK/Spit 1 & 10,163 & 7,565 \\
\hline UK/Spit 2 & 17,397 & 10,061 \\
\hline Australia E & 16,618 & 10,794 \\
\hline Australia S & 18,332 & 13,503 \\
\hline E Melanesia & 11,080 & 7,873 \\
\hline Papua New Guinea & 13,721 & 8,963 \\
\hline W Melanesia & 10,785 & 5,869 \\
\hline Mariana |sl & 12,155 & 11,752 \\
\hline Hawaii / Hawaii & 8,454 & 5,485 \\
\hline Marquesas & 10,715 & 10,589 \\
\hline Maui-Moloka & 8,504 & \\
\hline
\end{tabular}

\begin{tabular}{|c|c|c|c|c|c|c|c|}
\hline 10,627 & 0 & & & & & & \\
\hline 14,247 & 10,044 & 0 & & & & & \\
\hline 12,794 & 12,941 & 5,423 & 0 & & & & \\
\hline 10,114 & 9,938 & 5,363 & 4,257 & 0 & & & \\
\hline 19,079 & 15,111 & 10,940 & 6,952 & 6,592 & 0 & & \\
\hline 13,024 & 13,351 & 11,968 & 11,843 & 8,771 & 15,303 & 0 & \\
\hline 15,556 & 15,086 & 12,444 & 12,609 & 10,179 & 18,271 & 3,845 & 0 \\
\hline 14,042 & 10,475 & 6,096 & 7,329 & 7,208 & 14,317 & 10,227 & 10,755 \\
\hline 12,331 & 11,495 & 7,863 & 8,477 & 6,575 & 9,933 & 6,833 & 8,230 \\
\hline 11,743 & 8,371 & 4,509 & 5,657 & 5,528 & 9,877 & 7,429 & 8,489 \\
\hline 15,828 & 13,983 & 10,039 & 12,303 & 10,681 & 19,160 & 14,140 & 16,779 \\
\hline 10,943 & 7,385 & 8,650 & 7,619 & 5,659 & 11,581 & 10,097 & 10,281 \\
\hline 12,381 & 13,087 & 8,472 & 7,994 & 7,173 & 15,526 & 10,289 & 10,413 \\
\hline 11,751 & 8,536 & 6,053 & 6,314 & 4,248 & 10,040 & 8,700 & 8,404 \\
\hline
\end{tabular}


agrupamento populacional (Tabela 27) trás os Paleoíndios de Lagoa Santa mais próximas das populações paupásias, andamamense, nativa norte-americana da planície do norte; enquanto que as populações mais distantes são as tibetanas, chinesas do norte, javanesas, uma do Reino Unido (Spitalfield 2) e mexicanas.

O gráfico de Escalonamento Multidimensional para o agrupamento por populações locais, devido ao número de pontos a serem visualizados, é apresentado bidimensionalmente, e no agrupamento por grandes regiões geográficas tridimensinal. Em ambas as análises é possível observar a posição de outlier dos paleoíndios de Lagoa Santa. Na análise por populações locais (Figura 45) as populações asiáticas, polinésicas e européias estão associadas entre si em um bloco inferior do gráfico, enquanto que, no segundo adensamento populacional estão os nativos americanos, melanésicos, australianos e africanos, sendo estes os mais próximos de Lagoa Santa.

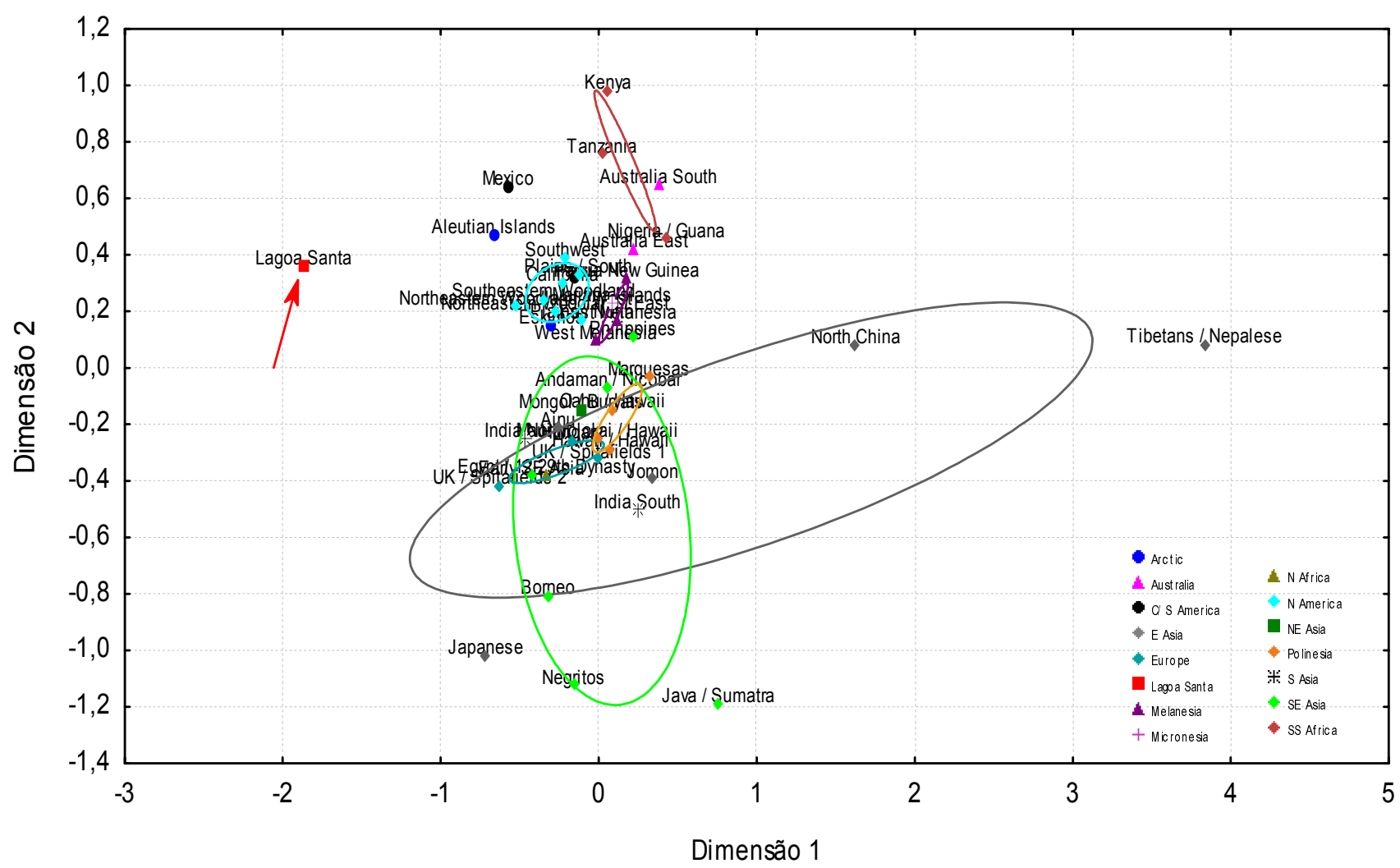

Figura 45 - Escalonamento Multidimensional produzido sobre a matriz de Distâncias de Mahalanobis (agrupamento por populações locais). Parcela feminina, tamanho e forma (43 populações, 32 variáveis). 
Tabela 28- Matriz de Distancias de Mahalanobis (populações agrupadas por grandes regiões geográficas). Parcela feminina, tamanho e forma (43 populações, 32 variáveis).

\begin{tabular}{|c|c|c|c|c|c|c|c|c|c|c|c|c|c|c|c|}
\hline & $\begin{array}{c}\mathrm{N} \\
\text { Africa } \\
\end{array}$ & $\begin{array}{c}\text { SS } \\
\text { Africa } \\
\end{array}$ & Arctic & $\begin{array}{c}\mathrm{C} / \mathrm{S} \\
\text { America } \\
\end{array}$ & $\begin{array}{c}\mathrm{N} \\
\text { America } \\
\end{array}$ & L Sta & E Asia & $\begin{array}{c}\text { NE } \\
\text { Asia } \\
\end{array}$ & S Asia & $\begin{array}{c}\text { SE } \\
\text { Asia } \\
\end{array}$ & Europe & Australia & Melanesia & Micronésia & Polinesia \\
\hline N Africa & 0 & & & & & & & & & & & & & & \\
\hline SS Africa & 8,567 & 0 & & & & & & & & & & & & & \\
\hline Arctic & 8,212 & 7,490 & 0 & & & & & & & & & & & & \\
\hline C/S America & 9,994 & 6,390 & 4,377 & 0 & & & & & & & & & & & \\
\hline N America & 6,494 & 4,127 & 2,158 & 2,361 & 0 & & & & & & & & & & \\
\hline L Sta & 16,545 & 12,945 & 15,196 & 15,679 & 12,648 & 0 & & & & & & & & & \\
\hline E Asia & 6,704 & 7,384 & 3,064 & 6,499 & 3,968 & 14,223 & 0 & & & & & & & & \\
\hline NE Asia & 6,065 & 6,134 & 3,657 & 6,650 & 3,689 & 13,423 & 2,620 & 0 & & & & & & & \\
\hline S Asia & 6,122 & 5,687 & 5,491 & 5,889 & 4,410 & 14,741 & 4,164 & 4,238 & 0 & & & & & & \\
\hline SE Asia & 6,736 & 4,759 & 4,644 & 5,536 & 3,382 & 13,636 & 2,688 & 2,494 & 3,262 & 0 & & & & & \\
\hline Europe & 4,441 & 5,818 & 5,819 & 8,023 & 4,582 & 14,035 & 3,404 & 3,407 & 2,654 & 3,349 & 0 & & & & \\
\hline Australia & 14,706 & 10,206 & 8,070 & 10,986 & 7,121 & 18,689 & 9,716 & 8,330 & 11,020 & 8,285 & 9,123 & 0 & & & \\
\hline Melanesia & 6,487 & 3,179 & 4,827 & 4,595 & 2,059 & 13,453 & 5,274 & 4,068 & 4,708 & 2,766 & 4,204 & 6,596 & 0 & & \\
\hline Micronésia & 15,575 & 9,245 & 10,056 & 9,347 & 8,331 & 15,528 & 9,953 & 8,545 & 12,053 & 7,870 & 10,561 & 15,283 & 6,585 & 0 & \\
\hline Polinesia & 7,569 & 5,607 & 6,071 & 6,476 & 4,103 & 13,843 & 4,623 & 2,997 & 4,775 & 2,792 & 4,553 & 7,857 & 2,881 & 7,398 & 0 \\
\hline
\end{tabular}

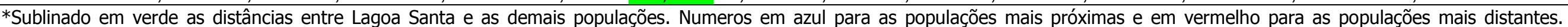


No agrupamento realizado sobre grandes regiões geográficas, a matriz de Distancias de Mahalanobis (Tabela 28) apresenta as populações mais associadas aos Paleoíndios são os nativos norte-americanos e africanos subsaarianos, e os mais distantes são os australianos e norte-africanos. Na Figura 46 é apresentado a visualização gráfica por meio da análise de Escalonamento Multidimensional tridimensional da matriz de distância de Mahalanobis gerada a partir da parcela feminina para tamanho e forma agrupados por grandes regiões geográficas. Mais uma vez é possível observar a posição de outilier dos paleoíndios de Lagoa Santa. O agrupamento norte-africano e micronésico também colocam-se como outliers. As populações asiáticas mantêm-se próximas entre si, enquanto que as populações africanas sub-saarianas associam-se as populações melanésicas, e os nativos norte americanos aproximam-se das populações australianas.

Na Tabela 29 é possível perceber que com a correção por C-Score, somente forma, a variância explicada por cada componente é menos discrepante, distribuindo melhor a variância explicada por cada Componente Principal, principalmente no que diz respeito ao Primeiro Componente em relação aos demais. $\mathrm{Na}$ representação gráfica do decaimento da representatividade dos componentes (Figura 47) é visível a ausência de uma queda tão abrupta quanto na análise feminina anterior (tamanho e forma).

Na Tabela 30 é representada a correlação das variáveis originais com os dois primeiros componentes principais extraídos dos dados corrigidos por CScore, ou seja, somente forma, na qual diversas variáveis mostram correlações altas em diferentes grupos dentários. As correlações maiores que 0,5 no 


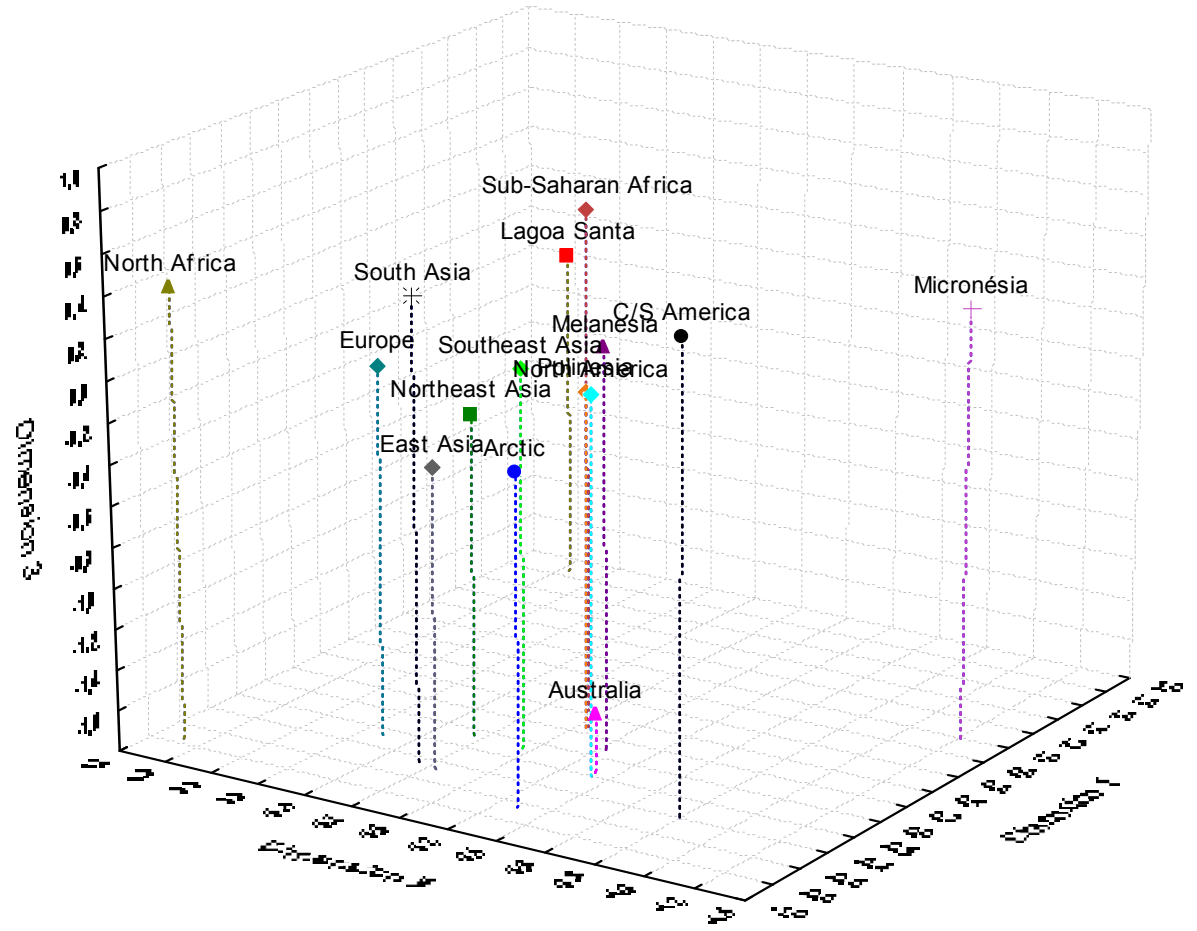

Figura 46 - Escalonamento Multidimensional produzido sobre a matriz de Distâncias de Mahalanobis (agrupamento por grandes regiões geográficas). Parcela feminina, tamanho e forma (43 populações, 32 variáveis).

Tabela 29 - Autovalores e percentagens de variância explicada pelos primeiros dezesseis Componentes Principais. Parcela feminina, somente forma (43 populações, 32 variáveis).

\begin{tabular}{ccccc}
\hline $\begin{array}{c}\text { Componente } \\
\text { Principal }\end{array}$ & Autovalor & $\begin{array}{c}\text { \% Total de } \\
\text { Variância Explicada }\end{array}$ & $\begin{array}{c}\text { Autovalor } \\
\text { Cumulativo }\end{array}$ & $\begin{array}{c}\% \\
\text { Cumulativa }\end{array}$ \\
\hline \hline 1 & 0,957227 & 27,03986 & 0,957227 & 27,0399 \\
2 & 0,497071 & 14,04133 & 1,454298 & 41,0812 \\
3 & 0,321544 & 9,08301 & 1,775842 & 50,1642 \\
4 & 0,251091 & 7,09284 & 2,026933 & 57,2570 \\
5 & 0,214991 & 6,07308 & 2,241924 & 63,3301 \\
6 & 0,184808 & 5,22048 & 2,426732 & 68,5506 \\
7 & 0,182562 & 5,15704 & 2,609294 & 73,7076 \\
8 & 0,160631 & 4,53751 & 2,769925 & 78,2451 \\
9 & 0,139693 & 3,94608 & 2,909618 & 82,1912 \\
10 & 0,100136 & 2,82865 & 3,009754 & 85,0199 \\
11 & 0,079943 & 2,25823 & 3,089697 & 87,2781 \\
12 & 0,064389 & 1,81887 & 3,154086 & 89,0970 \\
13 & 0,061951 & 1,75000 & 3,216037 & 90,8470 \\
14 & 0,050657 & 1,43096 & 3,266694 & 92,2779 \\
15 & 0,050099 & 1,41521 & 3,316793 & 93,6931 \\
16 & 0,038343 & 1,08312 & 3,355136 & 94,7763 \\
\hline
\end{tabular}


Primeiro Componente são positivas nos diâmetros mesiodistais e negativas no diâmetro bucolingual. As correlações positivas dos diâmetros mesidistais estão somente entre os dentes superiores: incisivo lateral, canino, segundo prémolar, primeiro e segundo molares. Nos diâmetros bucolinguais estão representados os dentes superiores canino e terceiro molar; e os dentes inferiores incisivos central e lateral, canino e primeiro pré-molar. Como as correlações não se encontram sistematicamente associadas a um grupo dentário específico, interpretações morfológicas são mais complexas. As correlações mais altas permitem afirmar que as populações na porção esquerda do morfo-espaço tem dentes superiores mais lateralizados e na porção direita dentes inferiores mais espessos.

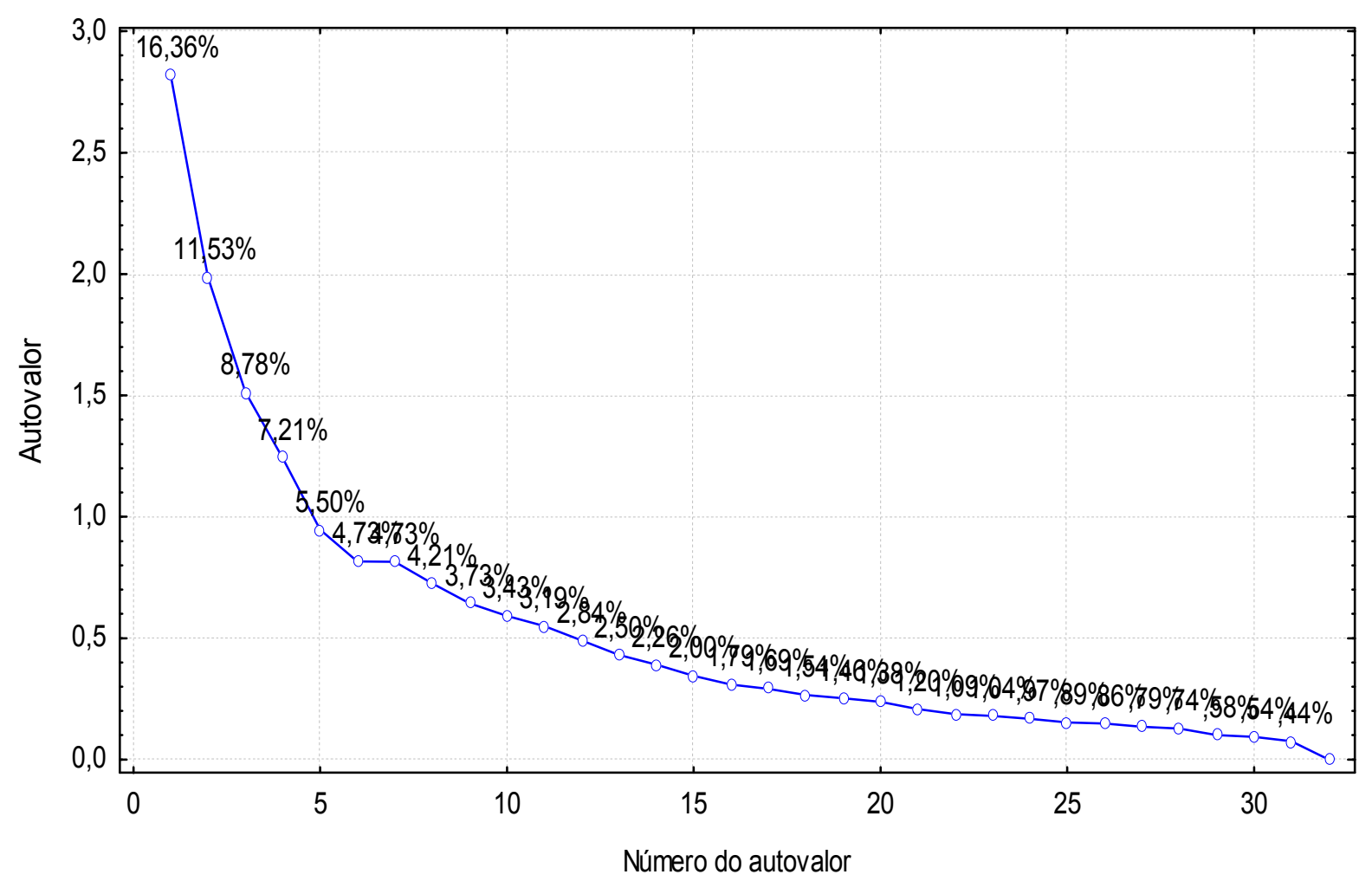

Figura 47 - Screeplot representando o decaimento das porcentagens de variância total explicadas por cada Componente Principal. Parcela Feminina, somente forma (43 populações, 32 variáveis). 
No que diz respeito a correlação das variáveis originais com o Segundo Componente Principal (Tabela 30), apenas 5 correlações são maiores que 0,5. No diâmetro mesiodistal as correlações são negativas nos dentes incisivo lateral superior e ambos incisivos (central e lateral) inferiores. No diâmetro bucolingual as correlações são positivas e estão nos dentes segundo e terceiro molares inferiores. Isso tem como conseqüência que as populações distribuídas na

Tabela 30 - Correlação entre as variáveis originais $\mathrm{e}$ os componentes principais extraídos. Parcela feminina, somente forma (43 populações, 32 variáveis).

\begin{tabular}{|c|c|c|}
\hline & Fator 1 & Fator 2 \\
\hline$\overline{M D ~ I 1 ~ U ~}$ & 0,4959 & 0,4722 \\
\hline MD I2 U & 0,5312 & $-0,5345$ \\
\hline MD C U & 0,6191 & $-0,4993$ \\
\hline MD PM1 U & 0,4196 & $-0,0667$ \\
\hline MD PM2 U & 0,5452 & $-0,2781$ \\
\hline MD M1 U & 0,6883 & 0,0898 \\
\hline MD M2 U & 0,5995 & 0,2635 \\
\hline MD M3 U & $-0,0600$ & 0,0699 \\
\hline MD I1 L & 0,0726 & $-0,5357$ \\
\hline MD I2 L & 0,3952 & $-0,6958$ \\
\hline MD C L & 0,4180 & 0,0819 \\
\hline MD PM1 L & $-0,0871$ & 0,1020 \\
\hline MD PM2 L & 0,2905 & 0,0322 \\
\hline MD M1 L & 0,4074 & $-0,3175$ \\
\hline MD M2 L & 0,4775 & 0,3203 \\
\hline MD M3 L & 0,0174 & $-0,2885$ \\
\hline BL I1 U & $-0,4471$ & $-0,1273$ \\
\hline $\mathrm{BL} 12 \mathrm{U}$ & $-0,1609$ & $-0,4109$ \\
\hline $\mathrm{BL} C \mathrm{U}$ & $-0,6820$ & 0,0868 \\
\hline BL PM1 U & $-0,4215$ & 0,1342 \\
\hline BL PM2 U & $-0,3923$ & 0,1426 \\
\hline $\mathrm{BL}$ M1 U & 0,0622 & $-0,1766$ \\
\hline $\mathrm{BL} M 2 \mathrm{U}$ & $-0,2364$ & 0,5035 \\
\hline BL M3 U & $-0,5115$ & 0,5619 \\
\hline BL I1 L & $-0,8008$ & $-0,4405$ \\
\hline $\mathrm{BL}$ I2 L & $-0,6757$ & $-0,2698$ \\
\hline BL C L & $-0,6680$ & 0,1575 \\
\hline BL PM1 L & $-0,7622$ & 0,2193 \\
\hline BL PM2 L & $-0,4739$ & 0,3359 \\
\hline $\mathrm{BL}$ M1 L & 0,1699 & $-0,2924$ \\
\hline BL M2 L & 0,0637 & 0,3325 \\
\hline BL M3 L & $-0,2568$ & $-0,1463$ \\
\hline
\end{tabular}

* destaque em vermelho para as correlações altas maiores que 0,5. 
porção superior do morfo-espaço da Figura 49 estão as populações com molares superiores mais espessos e na porção inferior as populações com dentes incisivos mais lateralizados.

A projeção da correlação entre as variáveis originais dos dois primeiros componentes (Figura 48) apresentam dispersão em todos os quadrantes do morfo-espaço. Porém, é possível observar que nos quadrantes inferiores existe uma concentração das variáveis referentes aos dentes incisivos (em verde). As projeções das medidas referentes aos molares (em laranja) estão concentradas na porção central do gráfico em todos os sentidos. As projeções referentes aos dentes pré-molares encontram-se dividas na porção esquerda (os diâmetros bucolinguais) e na porção da direita (os diâmetros mesiodistais), na interface entre as medidas dos incisivos e dos molares.

No gráfico do morfo-espaço dos dois primeiros componentes principais na Figura 49 é possível observar uma dispersão populacional diferente da gerada pelos dados brutos. $\mathrm{O}$ conjunto populacional que mais se destaca neste gráfico é o das populações nativas americanas, no extremo direito do gráfico com dentes inferiores mais espessos no entanto dentes incisivos mais lateralizados. As populações africanas constituem um agrupamento populacional também distinto, no quadrante superior direito do gráfico, definidos por molares e dentes inferiores mais espessos. As populações asiáticas e australo-melanésicas constituem um bloco único com sobreposição total das elipses, definidos principalmente por dentes superiores mais lateralizados. A grande dispersão da elipse do leste asiático é provocada pela posição extremamente distante da população do norte da China, que tem 
comportamento atípico (ou outlier). É possível visualizar facilmente que as demais populações estão concentradas na porção inferior da elipse do leste asiático, com praticamente total sobreposição com as populações do sudeste asiático, da Polinésia, da Melanésia e da Australia. A população de Lagoa Santa encontra-se dentro da elipse de dispersão do leste asiático que como já dito, encontra-se artificialmente ampliada, entretanto, desconsiderando esse artifício, os paleoíndios encontram-se próximos às populações do sudeste asiático e melanésicos, e são definidos por dentes superiores e incisivos mais lateralizados.

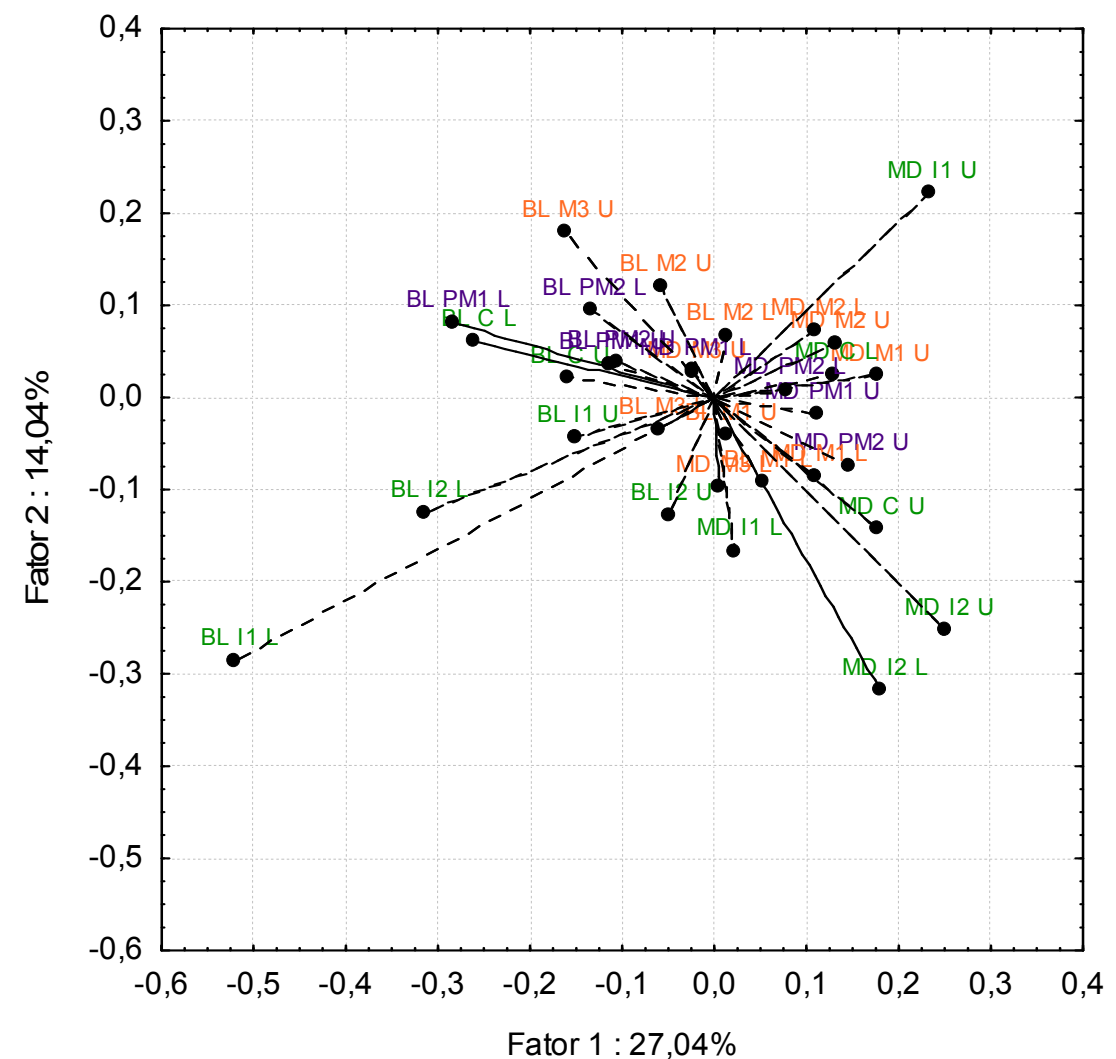

Figura 48 - Projeção das variáveis no morfo-espaço definido pelos dois primeiros Componentes Principais. Parcela feminina, somente forma (43 populações, 32 variáveis). 


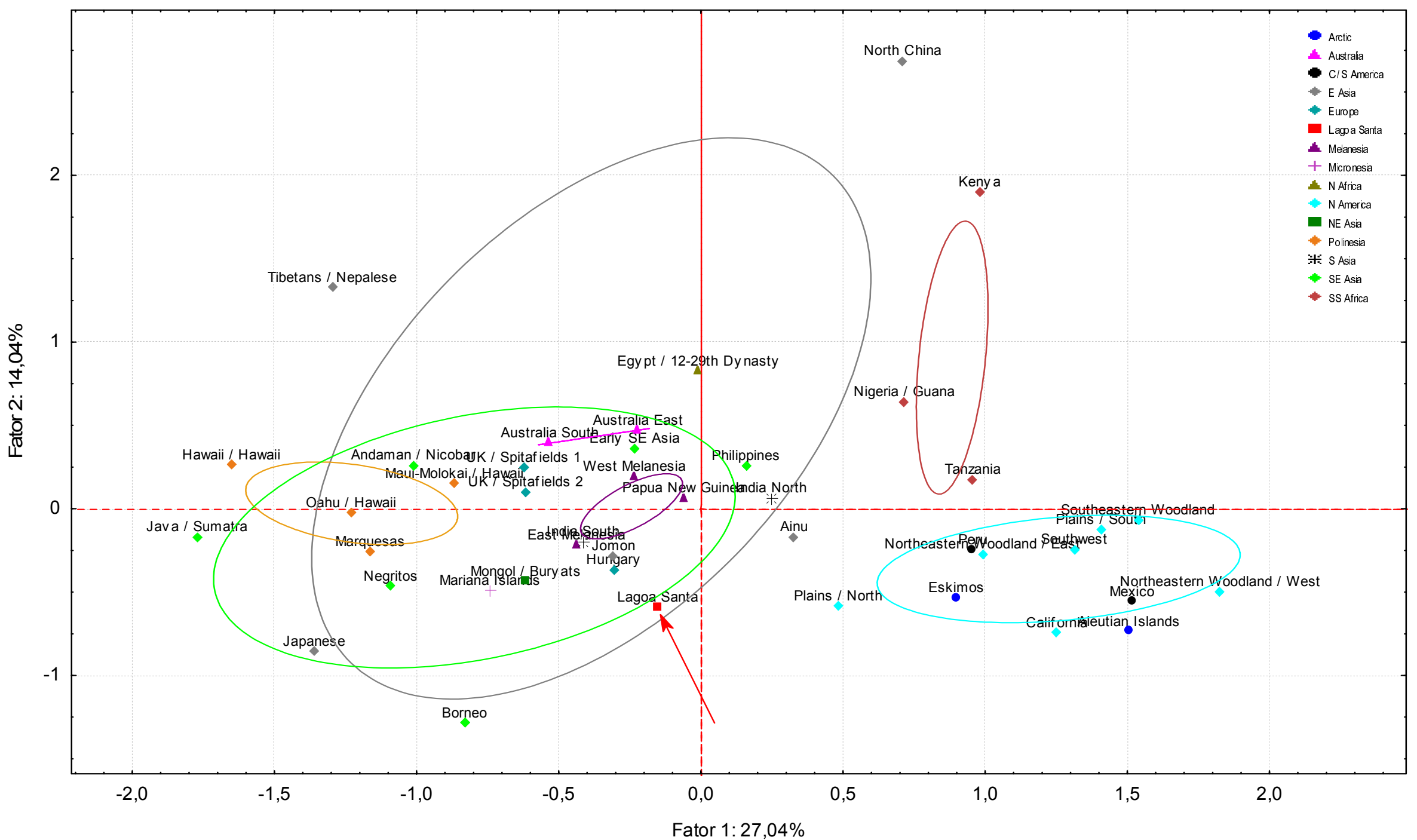

Figura 49 - Morfo-espaço formado pelos $1^{\circ}$ e $2^{\circ}$ componentes principais. Parcela feminina, somente forma (43 populações, 32 variáveis). 
A Tabela 31 apresenta os Índices Cofenéticos dos diferentes critérios de agregação (ligação simples, composta, ponderada pela média e não-ponderada pela média). Novamente, nenhum dos valores está de acordo com o valor mínimo esperado $(r=0,70)$, e o dendrograma obtido pelo método com o melhor resultado, o de ligação pela média não-ponderada e o dendrograma obtido pelo método de Ward são apresentados nas Figuras 50 e 51, respectivamente, pelo relaxamento do critério de exclusão.

Tabela 31 - Índices Cofenéticos para os diferentes critérios de "clustering" a partir de Distâncias Euclidianas. Parcela feminina, somente forma (43 populações, 32 variáveis).

\begin{tabular}{lc}
\hline Método de Agregação & Índice Cofenético $-r$ \\
\hline \hline Simples & 0,10527 \\
Composta & 0,23795 \\
média não ponderada & $\mathbf{0 , 4 1 8 6 1}$ \\
média ponderada & 0,38146 \\
\hline
\end{tabular}

No dendrograma da Figura 50 observa-se uma ausência de estruturação, já que grupos claramente distintos não são perceptíveis. A única exceção são os nativos americanos, que tendem a se aproximar na porção superior do gráfico, no primeiro grupo formado. As populações do Sudeste Asiático e da Polinésia se mantém, a grosso modo, levemente associadas na porção central do gráfico. Vale destacar que a população de Lagoa Santa não se encontra aos nativos americanos, estando localizada na região menos estruturada do dendrograma.

Apesar de mais estruturado, o dendrograma da Figura 48 também não apresenta uma lógica geográfica por trás dos agrupamentos populacionais. A única exceção é 
mais uma vez os nativas americanos que formam um grupo coeso na porção superior do gráfico. Porém, nesta topologia, essas populações são o primeiro agrupamento a divergir das demais populações mundiais (distância de análgama = 12).

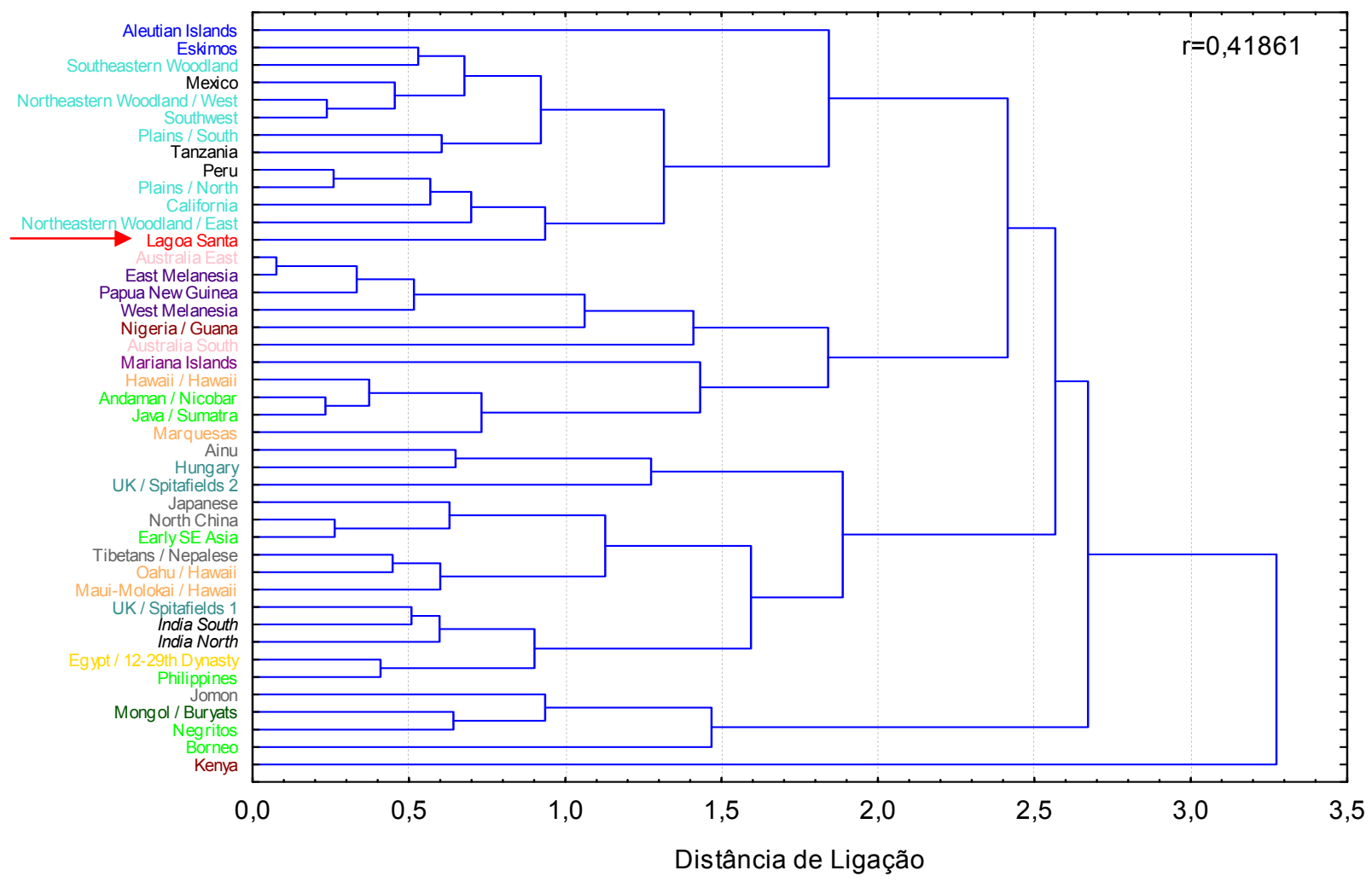

Figura 50 - Dendrograma produzido pelo critério de ligação por média não-ponderada a partir dos cinco primeiros componentes principais (Distâncias Euclidianas). Parcela feminina, somente forma.

De acordo com a Tabela 32 os valores dos índices cofenéticos tanto pelo critério de agrupamento de ligação pela média ponderada quanto pela média não ponderada são muito próximos, e extremamente baixos $(r<0,4)$ quando gerados sobre as Distâncias de Mahalanobis (Tabela 33 e 34). Por isso, nenhum dendrograma será apresentado para o agrupamento por população local nem para 
grandes regiões geográficas para a parcela feminina, somente forma.

Tabela 32 - Índices Cofenéticos para os diferentes critérios de "clustering" a partir de Distâncias de Mahalanobis. Parcela femina, somente forma (43 populações, 32 variáveis).

\begin{tabular}{llc}
\hline Classificação & Método de Agregação & $\begin{array}{c}\text { Índice Cofenético - } \\
\text { r }\end{array}$ \\
\hline \hline Populacional & simples & 0,15573 \\
Populacional & composta & 0,22196 \\
Populacional & média não ponderada & $\mathbf{0 , 3 6 1 5 5}$ \\
Populacional & média ponderada & 0,30697 \\
Grandes regiões & simples & 0,25932 \\
Grandes regiões & composta & 0,29116 \\
Grandes regiões & média não ponderada & $\mathbf{0 , 3 4 8 1 5}$ \\
Grandes regiões & média ponderada & 0,29554 \\
\hline
\end{tabular}

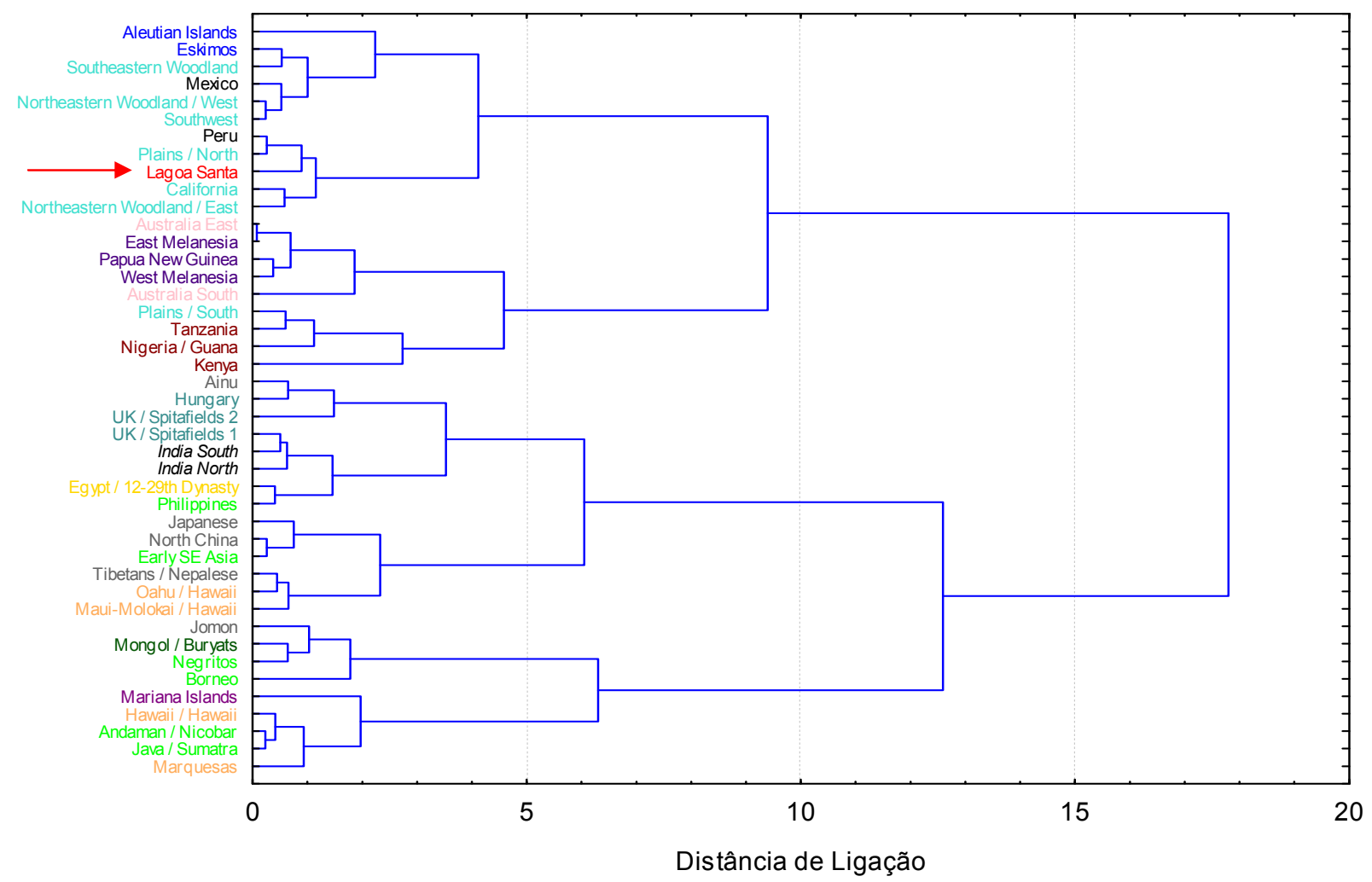

Figura 51 - Dendrograma produzido pelo critério de Ward a partir dos cinco primeiros componentes principais (Distancias Euclidianas). Parcela feminina, somente forma. 
Tabela 33 - Matriz de Distâncias de Mahalanobis (agrupamento realizado por populações locais). Parcela feminina, somente forma (43 populações, 32 vairáveis).

\begin{tabular}{|c|c|c|c|c|c|c|c|c|c|c|c|c|c|c|c|c|c|c|c|c|c|c|c|c|c|}
\hline & $\begin{array}{c}\text { Egypt / 12-29th } \\
\text { Dyn }\end{array}$ & Kenya & $\begin{array}{c}\text { Nigeria/ } \\
\text { Guana }\end{array}$ & Tanzania & $\begin{array}{c}\text { Aleutian } \\
\text { Isl }\end{array}$ & Eskimos & Mexico & Peru & California & $\begin{array}{c}\mathrm{NE} \\
\text { Woodland / } \\
\mathrm{E}\end{array}$ & $\begin{array}{c}\mathrm{NE} \\
\text { Woodland/ } \\
\mathrm{W}\end{array}$ & $\begin{array}{c}\text { Plains/ } \\
\mathrm{N}\end{array}$ & $\begin{array}{c}\text { Plains/ } \\
\mathrm{s}\end{array}$ & $\begin{array}{c}\text { SE } \\
\text { Woodland }\end{array}$ & Southwest & LSta & Ainu & Japanese & Jomon & N China & $\begin{array}{l}\text { Tibetans / } \\
\text { Nepalese }\end{array}$ & $\begin{array}{c}\text { Mongol/ } \\
\text { Buryats }\end{array}$ & India N & India S & $\begin{array}{l}\text { Andaman } / \\
\text { Nicobar } \\
\end{array}$ \\
\hline Egypt / 12-29th Dyn & 0 & & & & & & & & & & & & & & & & & & & & & & & & \\
\hline Kenya & 5,4273 & 0 & & & & & & & & & & & & & & & & & & & & & & & \\
\hline Nigeria / Guana & 5,3618 & 4,201 & 0 & & & & & & & & & & & & & & & & & & & & & & \\
\hline Tanzania & 8,9875 & 8,937 & 4,850 & 0 & & & & & & & & & & & & & & & & & & & & & \\
\hline Aleutian Isl & 8,0087 & 6,327 & 3,639 & 5,129 & 0 & & & & & & & & & & & & & & & & & & & & \\
\hline Eskimos & 6,4944 & 6,662 & 4,601 & 5,790 & 4,528 & 0 & & & & & & & & & & & & & & & & & & & \\
\hline Mexico & 13,7511 & 13,825 & 13,124 & 14,194 & 15,806 & 8,037 & 0 & & & & & & & & & & & & & & & & & & \\
\hline Peru & 7,2675 & 6,239 & 4,868 & 7,024 & 5,429 & 2,225 & 10,506 & 0 & & & & & & & & & & & & & & & & & \\
\hline California & 9,8272 & 7,352 & 6,000 & 9,556 & 6,530 & 6,359 & 18,292 & 5,041 & 0 & & & & & & & & & & & & & & & & \\
\hline NE Woodland/E & 7,9307 & 4,465 & 3,154 & 6,047 & 3,058 & 1,744 & 10,796 & 2,290 & 4,797 & 0 & & & & & & & & & & & & & & & \\
\hline NE Woodland/W & 7,8728 & 7,363 & 4,996 & 7,216 & 5,245 & 3,630 & 15,361 & 5,412 & 8,747 & 4,333 & 0 & & & & & & & & & & & & & & \\
\hline Plains / N & 5,0038 & 3,098 & 1,838 & 6,385 & 3,825 & 2,846 & 12,333 & 3,202 & 5,281 & 1,675 & 3,862 & 0 & & & & & & & & & & & & & \\
\hline Plains $/ \mathrm{s}$ & 9,1297 & 7,744 & 5,084 & 8,702 & 7,108 & 5,285 & 10,328 & 5,326 & 8,604 & 3,609 & 8,143 & 5,021 & 0 & & & & & & & & & & & & \\
\hline SE Woodland & 6,9264 & 5,836 & 3,605 & 5,938 & 5,330 & 3,706 & 10,936 & 3,388 & 5,050 & 2,761 & 7,122 & 3,219 & 2,671 & 0 & & & & & & & & & & & \\
\hline Southwest & 8,1425 & 9,718 & 6,083 & 7,355 & 8,336 & 6,404 & 14,114 & 7,759 & 9,736 & 7,328 & 8,112 & 6,444 & 8,843 & 6,133 & 0 & & & & & & & & & & \\
\hline L sta & 6,1212 & 6,848 & 4,262 & 6,456 & 5,672 & 4,256 & 13,783 & 4,049 & 5,852 & 4,057 & 5,316 & 3,555 & 5,621 & 4,635 & 5,045 & 0 & & & & & & & & & \\
\hline Ainu & 8,6061 & 9,171 & 8,774 & 12,281 & 8,385 & 6,612 & 15,253 & 5,035 & 8,738 & 5,298 & 10,696 & 5,183 & 8,014 & 6,089 & 9,871 & 6,378 & 0 & & & & & & & & \\
\hline Japanese & 9,9016 & 9,941 & 8,738 & 13,176 & 9,170 & 8,181 & 20,341 & 6,433 & 10,732 & 8,330 & 10,831 & 7,655 & 12,225 & 8,488 & 12,049 & 7,525 & 7,607 & 0 & & & & & & & \\
\hline Jomon & 7,7219 & 5,816 & 3,875 & 7,939 & 4,235 & 2,372 & 10,933 & 2,611 & 3,971 & 1,693 & 6,054 & 2,613 & 3,951 & 1,827 & 7,727 & 4,822 & 4,456 & 6,144 & 0 & & & & & & \\
\hline N China & 18,1561 & 14,118 & 15,375 & 18,891 & 16,613 & 11,012 & 19,987 & 12,589 & 16,718 & 11,661 & 13,532 & 11,216 & 14,133 & 13,914 & 11,629 & 10,860 & 16,539 & 21,685 & 13,157 & 0 & & & & & \\
\hline Tibetans / Nepalese & 16,4457 & 11,515 & 12,664 & 17,035 & 16,658 & 13,538 & 17,494 & 10,083 & 17,531 & 11,979 & 17,649 & 12,241 & 15,278 & 13,730 & 16,115 & 14,743 & 14,679 & 18,460 & 13,406 & 17,452 & 0 & & & & \\
\hline Mongol / Buryats & 7,2063 & 4,557 & 3,679 & 8,506 & 6,080 & 3,793 & 9,956 & 3,538 & 4,326 & 2,621 & 7,180 & 2,409 & 4,370 & 1,811 & 6,291 & 3,999 & 5,235 & 8,455 & 2,103 & 12,271 & 10,954 & 0 & & & \\
\hline India N & 17,7799 & 12,748 & 13,497 & 14,778 & 11,517 & 10,432 & 19,343 & 9,234 & 11,851 & 8,665 & 13,526 & 10,363 & 10,956 & 8,424 & 14,563 & 11,446 & 9,153 & 14,885 & 9,270 & 16,691 & 13,955 & 8,949 & 0 & & \\
\hline Indias & 12,8195 & 13,035 & 13,364 & 16,095 & 14,034 & 7,926 & 17,048 & 10,485 & 12,869 & 7,591 & 12,510 & 9,623 & 11,216 & 11,156 & 12,747 & 11,462 & 10,891 & 14,923 & 9,629 & 15,849 & 22,021 & 11,159 & 11,856 & 0 & \\
\hline Andaman / Nicobar & 9,3303 & 5,801 & 5,471 & 10,240 & 5,362 & 4,615 & 12,833 & 5,014 & 7,595 & 2,847 & 5,705 & 2,962 & 5,438 & 5,078 & 9,605 & 8,126 & 7,609 & 11,670 & 3,668 & 12,274 & 15,271 & 4,970 & 12,430 & 9,675 & 0 \\
\hline Borneo & 12,2841 & 8,494 & 5,943 & 10,571 & 7,027 & 4,610 & 10,901 & 6,432 & 7,675 & 4,948 & 8,625 & 5,690 & 7,927 & 7,133 & 12,482 & 9,742 & 10,531 & 14,150 & 5,189 & 15,809 & 15,103 & 6,834 & 13,004 & 10,429 & 6,277 \\
\hline Early SE Asia & 14,2296 & 9,930 & 11,301 & 13,567 & 11,203 & 6,879 & 16,215 & 7,509 & 8,897 & 6,913 & 12,552 & 7,833 & 11,310 & 10,141 & 12,321 & 11,113 & 9,678 & 13,259 & 7,474 & 15,124 & 18,580 & 9,968 & 13,171 & 9,996 & 8,353 \\
\hline Java / Sumatra & 12,4123 & 10,497 & 8,424 & 15,245 & 8,551 & 9,449 & 16,437 & 9,077 & 12,339 & 8,427 & 11,587 & 9,163 & 11,779 & 11,204 & 13,634 & 16,445 & 12,599 & 16,933 & 8,238 & 22,678 & 18,590 & 12,152 & 18,649 & 16,057 & 6,437 \\
\hline Negritos & 14,6913 & 9,152 & 10,827 & 17,772 & 10,494 & 11,610 & 14,573 & 9,268 & 10,207 & 8,363 & 12,080 & 8,273 & 12,386 & 9,174 & 16,001 & 13,037 & 12,643 & 17,030 & 8,954 & 20,440 & 19,693 & 9,308 & 12,829 & 15,463 & 7,202 \\
\hline Philippines & 11,7860 & 10,032 & 7,978 & 12,591 & 6,854 & 5,546 & 12,113 & 5,013 & 9,001 & 5,324 & 8,762 & 6,418 & 8,302 & 6,728 & 11,708 & 7,918 & 8,131 & 8,252 & 4,512 & 19,154 & 16,618 & 5,967 & 13,516 & 13,607 & 9,406 \\
\hline Hungary & 7,7706 & 7,357 & 6,140 & 11,100 & 5,439 & 4,462 & 13,905 & 4,575 & 7,612 & 4,086 & 9,632 & 4,532 & 7,691 & 4,596 & 10,452 & 6,891 & 4,776 & 6,844 & 2,842 & 17,455 & 12,410 & 4,014 & 11,994 & 11,151 & 6,046 \\
\hline UK / Spit 1 & 7,2615 & 6,641 & 5,556 & 11,857 & 7,007 & 4,849 & 12,752 & 4,815 & 7,847 & 3,716 & 10,278 & 4,186 & 6,516 & 4,461 & 10,394 & 6,956 & 5,801 & 4,469 & 2,289 & 15,721 & 12,845 & 3,444 & 10,901 & 9,906 & 6,658 \\
\hline UK/Spit2 2 & 13,9202 & 16,372 & 14,075 & 20,087 & 13,261 & 13,376 & 24,659 & 15,241 & 17,038 & 13,019 & 14,744 & 12,537 & 16,107 & 14,091 & 18,572 & 18,182 & 15,487 & 17,009 & 11,522 & 25,003 & 22,697 & 13,506 & 19,443 & 19,362 & 15,402 \\
\hline Australia E & 12,9167 & 12,319 & 12,275 & 17,533 & 12,674 & 11,095 & 19,794 & 10,163 & 12,816 & 10,001 & 14,583 & 9,151 & 12,019 & 7,957 & 14,349 & 12,240 & 9,292 & 9,317 & 7,465 & 18,122 & 17,590 & 7,455 & 16,454 & 16,565 & 10,769 \\
\hline Australia S & 9,4994 & 10,252 & 9,085 & 10,168 & 8,627 & 4,836 & 12,668 & 5,721 & 7,985 & 6,081 & 11,005 & 7,121 & 8,641 & 5,406 & 12,277 & 9,307 & 7,352 & 7,928 & 3,433 & 20,168 & 16,587 & 6,286 & 12,338 & 10,163 & 8,641 \\
\hline E Melanesia & 8,7579 & 8,646 & 7,284 & 9,845 & 5,708 & 5,025 & 15,414 & 4,186 & 7,603 & 4,376 & 7,957 & 4,943 & 5,069 & 5,235 & 11,454 & 6,763 & 5,902 & 9,627 & 4,401 & 14,197 & 17,586 & 7,419 & 10,525 & 8,790 & 5,494 \\
\hline Papua New Guinea & 8,6114 & 7,416 & 6,242 & 10,104 & 5,446 & 5,202 & 15,136 & 5,005 & 7,556 & 3,699 & 5,719 & 4,345 & 3,786 & 4,515 & 9,048 & 5,809 & 7,328 & 9,695 & 3,924 & 15,282 & 16,842 & 6,118 & 9,189 & 10,490 & 5,080 \\
\hline w Melanesia & 7,5127 & 5,920 & 5,490 & 8,613 & 5,787 & 2,814 & 9,540 & 3,202 & 6,745 & 3,194 & 4,235 & 3,660 & 4,790 & 4,612 & 7,602 & 5,168 & 6,603 & 9,431 & 3,441 & 12,678 & 13,997 & 4,301 & 9,562 & 8,800 & 4,196 \\
\hline Mariana Isl & 6,7387 & 5,163 & 4,971 & 7,719 & 5,694 & 2,768 & 10,106 & 3,000 & 6,682 & 1,995 & 4,936 & 2,484 & 4,741 & 3,794 & 8,176 & 6,102 & 5,451 & 8,663 & 3,052 & 13,790 & 12,905 & 3,997 & 7,859 & 6,982 & 3,353 \\
\hline Hawaii / Hawaii & 10,1581 & 8,447 & 7,348 & 11,975 & 7,442 & 6,596 & 12,272 & 7,735 & 9,647 & 6,410 & 7,449 & 6,736 & 5,539 & 6,421 & 11,216 & 10,118 & 10,869 & 15,595 & 6,579 & 18,294 & 19,777 & 8,813 & 14,318 & 9,324 & 5,328 \\
\hline Marquesas & 7,4930 & 6,359 & 4,982 & 10,593 & 6,429 & 5,217 & 12,648 & 3,999 & 7,559 & 4,159 & 6,771 & 3,418 & 6,271 & 6,393 & 9,275 & 6,306 & 6,263 & 9,429 & 5,138 & 13,848 & 15,970 & 6,421 & 11,761 & 9,278 & 4,200 \\
\hline Maui-Molokai / Hawaii & 10,8430 & 6,785 & 5,204 & 9,882 & 5,083 & 4,778 & 14,198 & 5,629 & 7,979 & 2,712 & 6,072 & 4,281 & 5,888 & 6,088 & 11,721 & 7,378 & 7,541 & 9,656 & 4,857 & 16,961 & 16,162 & 6,392 & 11,598 & 9,328 & 3,860 \\
\hline Oahu / Hawaii & 7,9141 & 5,510 & 3,710 & 6,776 & 4,673 & 2,320 & 11,020 & 3,098 & 5,062 & 1,404 & 5,025 & 2,703 & 2,363 & 1,922 & 6,523 & 3,848 & 5,303 & 7,126 & 1,465 & 11,953 & 12,922 & 2,726 & 7,550 & 6,884 & 3,179 \\
\hline
\end{tabular}


(Continuação) Tabela 33 - Matriz de Distâncias de Mahalanobis (agrupamento realizado por populações locais). Parcela feminina, somente forma (43 populações, 32 variáveis).

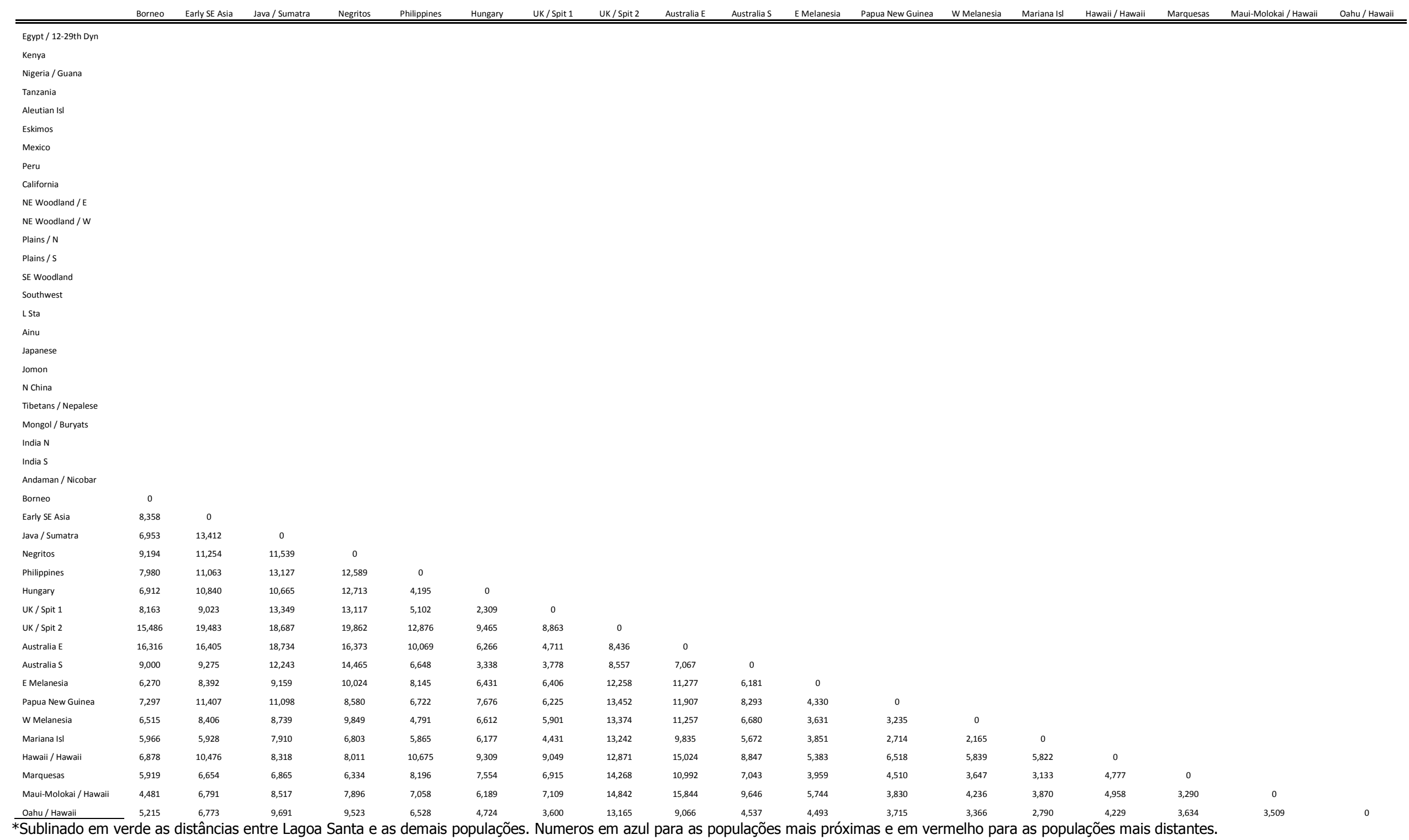


As matrizes de Distancias de Mahalanobis para ambos os níveis de agrupamento são apresentadas nas Tabelas 33 e 34, respectivamente. No agrupamento populacional (Tabela 33) as populações mais próximas dos Paleoíndios de Lagoa Santa são as populações de havaianas da ilha de Oahu, mongóis, jomonesas, nativas norte-americanas do sudeste e nordeste de Woodland, peruanas, esquimós, nigerianas; enquanto que as mais distantes são: mexicanas, tibetanas, javanesas, negritos, e do Reino Unido de Spitalfield 2.

A matriz de Distância de Mahalanobis para agrupamento por populações locais é visualizado na Análise de Escalonamento Multidimensional (Figura 52). Na visualização gráfica, é possível observar que não existe uma separação nítida entre as populações que formam um aglomerado na região central do gráfico. As populações que se destacam, comportam-se claramente como outliers, e são: tibetanos, chineses do norte, mexicanos e inglesas de Spitafields 2. Os paleoiíndios de Lagoa Santa estão encorporados no adensamento populacional.

Já a matriz de Distâncias de Mahalanobis com as populações agrupadas por grandes regiões geográficas (Tabela 34) associa os paleoíndios de Lagoa Santa mais perto das populações nativas norte-americanas, árticas e africanas subsaarianas, enquanto que as distancia das populações australianas e Sul Asiáticas. A Figura 53 apresenta a visualização pelo Escalonamento Multidimensional da Matriz de Mahalanobis gerado a partir do agrupamento por grandes regiões geográficas para a parcela feminina com os dados para somente forma. Neste nível de agrupamento, a população de Lagoa Santa encontra-se associada com as 
Tabela 34 - Matriz de Distâncias de Mahalanobis (populações agrupadas por grandes regiões geográficas). Parcela feminina, somente forma (43 populações, 32 variáveis).

\begin{tabular}{|c|c|c|c|c|c|c|c|c|c|c|c|c|c|c|c|}
\hline & N Africa & SS Africa & Arctic & $\begin{array}{c}\mathrm{C} / \mathrm{S} \\
\text { America } \\
\end{array}$ & $\begin{array}{c}\mathrm{N} \\
\text { America } \\
\end{array}$ & L Sta & E Asia & $\begin{array}{c}\mathrm{NE} \\
\text { Asia } \\
\end{array}$ & S Asia & $\begin{array}{c}\text { SE } \\
\text { Asia } \\
\end{array}$ & Europe & Australia & Melanesia & Micronésia & Polinesia \\
\hline N Africa & 0 & & & & & & & & & & & & & & \\
\hline SS Africa & 4,672 & 0 & & & & & & & & & & & & & \\
\hline Arctic & 5,560 & 2,953 & 0 & & & & & & & & & & & & \\
\hline C/S America & 6,936 & 4,327 & 1,973 & 0 & & & & & & & & & & & \\
\hline N America & 5,113 & 1,439 & 1,343 & 2,352 & 0 & & & & & & & & & & \\
\hline L Sta & 6,121 & 3,802 & 3,725 & 4,869 & 2,589 & 0 & & & & & & & & & \\
\hline E Asia & 6,708 & 4,732 & 3,024 & 3,130 & 2,163 & 4,195 & 0 & & & & & & & & \\
\hline NE Asia & 7,206 & 3,304 & 3,644 & 3,306 & 1,595 & 3,999 & 2,485 & 0 & & & & & & & \\
\hline S Asia & 12,652 & 9,558 & 6,315 & 7,200 & 5,823 & 8,605 & 5,355 & 6,855 & 0 & & & & & & \\
\hline SE Asia & 8,534 & 4,093 & 2,554 & 3,051 & 2,303 & 6,610 & 3,091 & 4,172 & 6,283 & 0 & & & & & \\
\hline Europe & 6,715 & 5,524 & 3,897 & 4,808 & 3,671 & 6,898 & 2,448 & 3,367 & 7,562 & 3,948 & 0 & & & & \\
\hline Australia & 8,777 & 8,001 & 5,032 & 5,668 & 5,335 & 8,565 & 3,860 & 5,173 & 8,829 & 6,044 & 1,960 & 0 & & & \\
\hline Melanesia & 6,943 & 4,461 & 2,461 & 3,096 & 1,928 & 4,583 & 3,020 & 3,902 & 5,567 & 2,595 & 5,093 & 5,786 & 0 & & \\
\hline Micronésia & 6,739 & 4,223 & 2,649 & 2,890 & 2,249 & 6,102 & 3,223 & 3,997 & 4,679 & 1,869 & 4,686 & 5,535 & 1,558 & 0 & \\
\hline Polinesia & 7,526 & 3,017 & 2,094 & 3,093 & 1,126 & 4,208 & 2,415 & 3,403 & 4,764 & 1,794 & 3,742 & 4,728 & 1,782 & 2,152 & 0 \\
\hline
\end{tabular}

*Sublinado em verde as distâncias entre Lagoa Santa e as demais populações. Numeros em azul para as populações mais próximas e em vermelho para as populações mais distantes. 


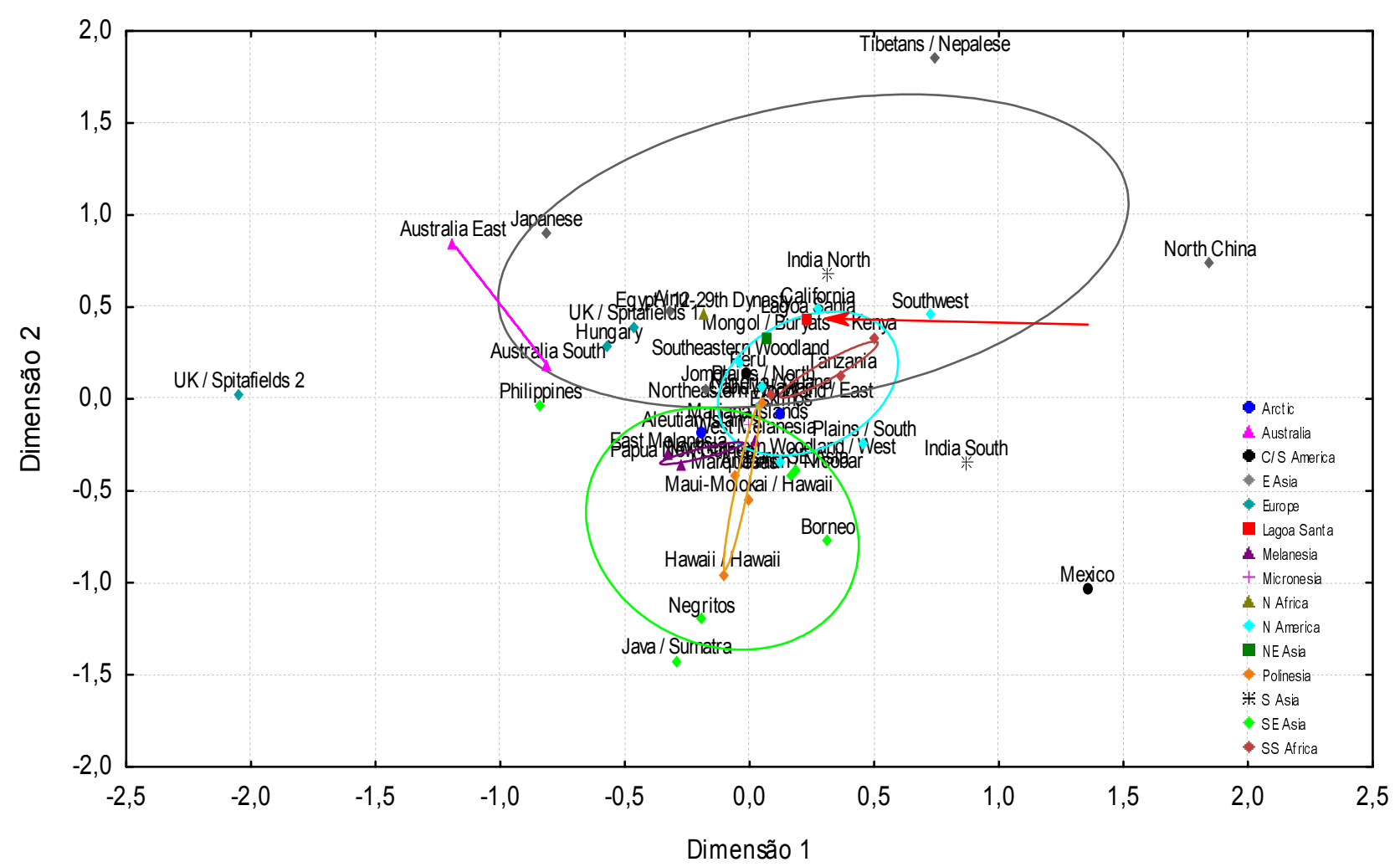

Figura 52 - Escalonamento Multidimensional produzido sobre a matriz de Distâncias de Mahalanobis (agrupamento por populações locais). Parcela feminina, somente forma (43 populações, 32 variáveis).

populações africanas (tanto norte africanas quanto sub-saarianas). As associações obtidas são: as populações melanésicas estão associadas com as micronésicas e Sudeste Asiática; as populações nativas americanas com as populações do Ártico e Leste Asiáticas; e, as populações polinésicas em posição intermediária entre o agrupamento melanésico/micronésico/Sudeste Asiático e nativos americanos/Leste Asiático/Ártico. Individualizadas, mas não necessariamente como outliers estão as populações australianas, européias e do Nordeste e Sul Asiáticos que não se associam com outros grupos humanos. 


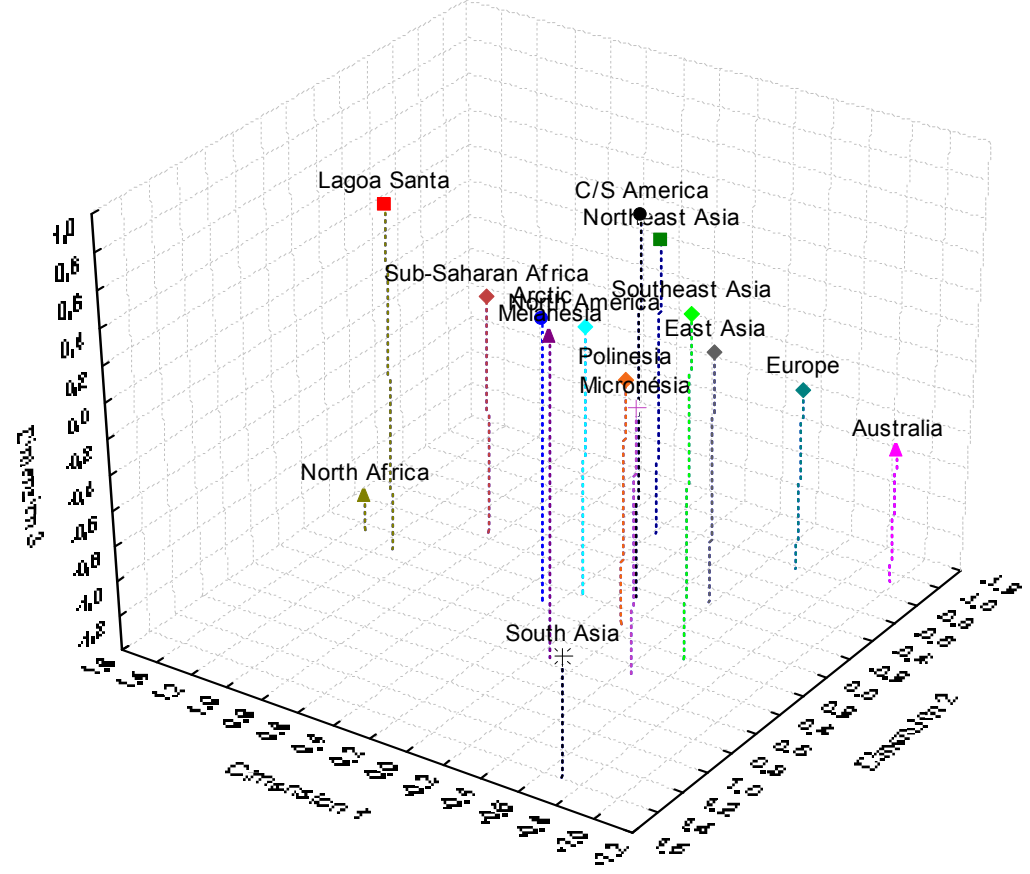

Figura 53 - Escalonamento Multidimensional produzido sobre a matriz de Distâncias de Mahalanobis (populações agrupadas por grandes regiões geográficas). Parcela feminina, somente forma (43 populações, 32 variáveis).

Em suma, a Tabela 35 condensa os resultados aqui obtidos tanto para tamanho e forma quanto para forma somente. Destacado em verde estão as associações dos paleoíndios de Lagoa Santa com populações do Sudeste Asiático, enquanto que em laranja, as associações com populações polinésicas, as mais freqüentemente encontradas no trabalho. Vale destacar também, que em muitos casos a população de Lagoa Santa comporta-se como outlier. 
Tabela 35 - Resumo dos resultados obtidos

\begin{tabular}{|c|c|c|c|c|c|}
\hline & & \multicolumn{2}{|c|}{ PARCELA MASCULINA } & \multicolumn{2}{|c|}{ PARCELA FEMININA } \\
\hline & & tamanho e forma & somente forma & tamanho e forma & somente forma \\
\hline$P C A$ & & SE Asia & SE Asia + Polinesia & $\begin{array}{c}\text { Interm: America + SS } \\
\text { Africa + Australia + } \\
\text { Polinesia + SE Asia }\end{array}$ & SE Asia + Melanesia \\
\hline \multirow[t]{2}{*}{ CLUSTER } & UPGMA & - & Polinesia & America & America \\
\hline & WARD & - & Polinesia + SE Asia & America & America \\
\hline \multirow[t]{5}{*}{$\begin{array}{l}\text { MAHALANOBIS } \\
\text { (POPULAÇÃO) }\end{array}$} & MATRIZ + & $\begin{array}{c}\text { Andaman/Nicobar + } \\
\text { Myanmar + Early SE } \\
\text { Asia + India N + Russia } \\
+ \text { Early Iran + Mong/Bur } \\
\text { + Peru }\end{array}$ & $\begin{array}{l}\text { Europe + India S + } \\
\quad \text { Caroline Isl + } \\
\text { Andaman/Nicolbar }\end{array}$ & $\begin{array}{c}\text { Papua New Guinea + } \\
\text { Andaman/Nicolbar + } \\
\text { Plans/N }\end{array}$ & $\begin{array}{c}\text { Oahu + Mong/Bur + } \\
\text { America + Peru + } \\
\text { Eskimo + Nig/Guan + } \\
\text { Jomon }\end{array}$ \\
\hline & MATRIZ - & $\begin{array}{c}\text { Australia + Austria + } \\
\text { Czecho + Finland + UK + } \\
\text { Tanzania }\end{array}$ & $\begin{array}{c}\text { Europe + Australia + } \\
\text { Aleutas + Japonese + } \\
\text { Melanesia + Hawaii + } \\
\text { Fueginos + Egypt }\end{array}$ & $\begin{array}{c}\text { Tibet + N China + } \\
\text { Java/Sumatra + UK Spit } \\
2+\text { Mexico }\end{array}$ & $\begin{array}{c}\text { Mexico + Tibet }+ \\
\text { Java/Sumatra }+ \\
\text { Negritos + UK Spit } 2\end{array}$ \\
\hline & UPGMA & - & outlier & - & - \\
\hline & WARD & - & SE Asia & - & - \\
\hline & EMD & outlier & outlier & outlier & não discrimina \\
\hline \multirow[t]{5}{*}{$\begin{array}{l}\text { MAHALANOBIS } \\
\text { (GRUPOS) }\end{array}$} & MATRIZ + & $\begin{array}{c}\text { SE Asia + NE Asia + W } \\
\text { Asia }\end{array}$ & $\begin{array}{c}\text { C/S America + NE Asia + } \\
\text { SE Asia + W Asia }\end{array}$ & SS Africa + N America & $\begin{array}{c}\text { America + Artico + SS } \\
\text { Africa }\end{array}$ \\
\hline & MATRIZ - & Australia + Micronesia & Australia + SS Africa & N Africa + Australia & Australia + S Asia \\
\hline & UPGMA & outlier & outlier & - & - \\
\hline & WARD & outlier & outlier & - & - \\
\hline & EMD & outlier & outlier & outlier & $\begin{array}{c}\text { outlier + próx: N Africa + } \\
\text { SS Africa }\end{array}$ \\
\hline
\end{tabular}

\footnotetext{
* destaque em verde para a associação positiva dos paleoíndios de Lagoa Santa com populações do Sudeste Asiático e em laranja para a associação posiva para populações polinésicas.
} 


\section{Discussão e Conclusões}

A variabilidade da anatomia dentária humanas tem mostrado grande potencial como ferramenta para se entender relações fenéticas entre populações (e.g. Scott \& Turner, 1997). Tais inferências devem-se a uma série de características dentárias: são menos influenciadas por fatores ambientais imediatos do que o resto do esqueleto (Kieser, 1990; Larsen, 1997; Cardoso, 2007; Stojanowski et al., 2007); sua morfogênese é mais estável do que a de outros elementos ósseos (Jernevall \& Jung, 2000); e apresentam estimativas de herdabilidade geralmente altas, variando de 60 a $82 \%$ (Townsend et al., 2003). Portanto, os resultados aqui obtidos com respeito à distinção entre as populações humanas analisadas têm amplo embasamento genético.

Devido às diferenças de tamanho dentário comumente encontradas entre homens e mulheres (Brace, 1967; Brace \& Mahler, 1971; Brace \& Ryan, 1980; Brace \& Nagai, 1982), as análises por mim efetuadas foram feitas separadamente por sexo. Tal escolha mostrou-se apropriada, primeiro, pela grande diferença do tamanho amostral entre as parcelas masculinas e femininas, e segundo, pela diferença obtida nas associações biológicas das duas parcelas, por razões que serão discutidas a seguir.

A magnitude da correlação entre os diâmetros mesiodistal e bucolingual das coroas dentárias é sistematica e significativa, mas apenas $26 \%$ da variação do tamanho dos dentes são determinados por fatores comuns, indicando que as duas 
dimensões variam de forma mais ou menos autônoma (Garn et al., 1967; Hanihara \& Ishida, 2005). Portanto, apesar dos diâmetros dentários utilizados serem correlacionados, é possível notar nos gráficos de projeção das correlações entre as variáveis originais e os PCs gerados que diferentes regiões do morfo-espaço são afetados diferentemente pelas 32 variáveis incluídas neste estudo, demonstrando assim, a validade do uso de ambos os diâmetros (mesiodistal e bucolingual) de todas as categorias dentárias.

O componente "forma" tem sido sugerido na literatura como melhor estimador de divergência biológica entre populações, fazendo mais sentido geográfico do que a distribuição baseada no "tamanho e forma" (Penrose, 1954; Hanihara, 1977). Por isso, análises distintas foram realizadas para "tamanho e forma" e para "somente forma". Os resultados obtidos, no entanto, mostraram que o tamanho dentário foi extremamente eficiente para distinguir entre as populações humanas incluídas no trabalho, tanto quanto as análises baseadas em forma apenas.

Fazendo um paralelo com traços não-métricos e os clássicos padrões morfodentários sundadontes e sinodontes do "Complexo Dentário Mongolóide Asiático" (Hanihara, 1977; Turner II, 1990; Brace \& Hunt, 1990; Hanihara, 1996; Irish \& Guatelli-Steinberg, 2003), foi possível notar com os resultados aqui obtidos uma clivagem semelhante entre as populações asiáticas do sudeste e do leste. A origem de tal distinção está fora do escolpo deste trabalho. Entretanto, comparando o padrão de agrupamento das populações analisadas neste trabalho 
com dados da literatura, é possível sugerir que o padrão métrico existente no Sudeste Asiático seria mais antigo e coincidente com o sundadôntico (Brace, 1981, 1987; Turner II, 1990), tendo em vista uma maior aproximação destas populações com as populações africanas e australo-melanésicas nas análises métricas aqui realizadas. Como as populações africanas e australo-melanésias seriam as populações mais antigas e com padrões morfológicos menos especializados, elas serão aqui identificadas como tendo um padrão morfo-métrico generalizado.

Ainda considerando os padrões não-métricos, só que agora dos nativos americanos, Haydenblit (1996) ao estudar populações mexicanas pré-hispânicas tardias, mostrou que o padrão dentário dessa população diferenciava-se do clássico sinodonte, adequando-se mais ao padrão sundadonte, contrapondo-se fortemente às idéias de Turner (para uma síntese ver Greenberg et al., 1986). Suttler (1997) afirmou ter encontrado um aumento não-significativo nas freqüências dos traços sinodônticos em populações pré-históricas costeiras chilenas durante o Holoceno Médio. Quando tais populações foram comparadas com outros nativos americanos mostraram-se mais semelhantes aos paleoíndios, ou seja, ao padrão morfodentário sundadôntico. Powell \& Neves (1998) também não encontraram o padrão sinodôntico nos paleoíndios de Lagoa Santa, diferenciando-os dos demais nativos americanos e dos nordeste asiáticos. Tais resultados mostram que a mesma dicotomia populacional mostrada pelos estudos craniométricos também ocorre nos estudos morfo-dentários. 
A parcela masculina analisada neste trabalho associou-se sistematicamente às populações do Sudeste Asiático, tanto nas análises de componentes principais (baseada em "tamanho e forma" e em "forma apenas") quanto nas análises de distâncias biológicas. Mais especificamente, quando "tamanho e forma" são levados em consideração, os paleoíndios do sexo masculino apresentam afinidades mais próximas com as populações de morfologia dentária generalizada, ou seja, australianas, melanésicas, africanas e sudeste asiáticas (Figura 24). Quando apenas "forma" é levada em consideração, sobressai uma associação com os polinésios, tanto na $\mathrm{ACP}$, quanto na Análise de Cluster baseada em Distâncias Euclidianas (Figuras 31, 32, 33, respectivamente). As análises baseadas em matrizes de Distâncias de Mahalanobis colocam a população de Lagoa Santa ora como outlier, ora como grupo irmão das populações do Sudeste Asiático. Em nenhum momento a parcela masculina dos paleoíndios de Lagoa Santa associamse às populações nativas americanas.

As associações obtidas para a parcela feminina, de modo geral, aproximam a população de Lagoa Santa a diferentes populações de morfologia dentária generalizada - Sudeste Asiático, Melanésia, Austrália e África, conforme apresentado nas Figuras 42, 49, 50 e 51. A associação mais frequentemente obtida se deu com as populações do Sudeste Asiático quando apenas "forma" foi levada em consideração, tanto nas análises de componentes principais (Figura 49), quanto nos dendrogramas gerados a partir de matrizes de Distâncias Euclidianas (Figuras 50 e 51). Nas poucas vezes em que os paleoíndios de Lagoa Santa 
aproximaram-se dos demais nativos americanos, isto ocorreu de forma muito sutil, mantendo-os com um certo distanciamento (Figuras 42, 43 e 44).

De forma direta, os resultados aqui gerados questionam, veementemente a suposta homogeneidade biológica nativa americana como anteriormente sugerido por trabalhos clássicos de craniometria, variação dentária e biologia molecular (e.g. Hrdlička, 1907, 1912, 1932; Howells, 1973; Greenberg et al., 1986; Brace et al., 1987, 2001; Pena et al., 1995; Merriwether et al., 1995; Bonatto \& Salzano, 1997; Hammer \& Zegura, 2002; Rosenberg et al., 2002; Fagundes et al., 2008). A maioria esmagadora dos trabalhos sobre povoamento da América não incluiu amostras da transição Pleistoceno/Holoceno, deixando de lado, consequentemente, parte importante da história do continente americano.

Seguchi et al. (2006) analisaram alguns poucos dentes dos paleoíndios de Lagoa Santa (tamanho amostral exato não divulgado) sob a ótica odontométrica, tendo concluído que os paleoíndios de Lagoa Santa associam-se aos índios norteamericanos do período Arcaico, aos jomoneses e aos polinésicos. Apesar do material por eles publicado não apresentar informações completas sobre o trabalho desenvolvido, o que limita o diálogo com o mesmo, é possível afirmar de antemão que com um tamanho amostral mais expressivo (como o aqui utilizado) não ocorre qualquer associação entre os paleoíndios e os nativos americanos mais tardios. Uma discreta aproximação entre esses dois grupos pôde ser aqui observada somente para a parcela feminina, porém com considerável distanciamento (cabe lembrar que o tamanho amostral da parcela feminina limita muito qualquer 
conclusão a partir dela). A associação com populações polinésicas obtidas neste trabalho está parcialmente de acordo com os resultados de Seguchi et al. (2006), sugerindo, que mesmo com um tamanho amostral reduzido, um padrão morfológico comum subjacente veio à tona em ambos os trabalhos.

A associação da população de Lagoa Santa com populações do Sudeste Asiático e da Polinéisa aqui obtida permite sugerir a existência de um padrão dentário generalizado e distinto do descrito para os nativos americanos tardios presente na América nos momentos iniciais do povoamento do continente. As populações polinésicas e sudeste asiáticas aqui analisadas apresentam padrões morfo-dentários bastante semelhantes entre si, com dentes de tamanho mediano e geralmente espessos (principalmente os pré-molares). Com freqüência nas análises aqui realizadas a elipse de dispersão do Sudeste Asiático sobrepõe-se à elipse da Polinésia. O padrão morfo-dentário obtido para os paleoíndios de Lagoa Santa por sua vez, caracteriza-se por apresentar dentes entre medianos e grandes e dentes anteriores e pré-molares mais espessos, tanto para a parcela masculina quanto para a feminina.

A associação dos paleoíndios de Lagoa Santa com populações de morfologia craniana generalizada do Velho Mundo (para uma síntese ver Neves \& Hubbe, 2005) está de acordo com os resultados odontométricos obtidos neste trabalho. No entanto, os trabalhos de Neves e associados têm relacionado os primeiros sulamericanos mais intimamente com populações africanas e australo-melanésicas, o que neste trabalho não ocorreu. Os estudos de Brace (1971, 1980, 1984, 1987 e 
2001) sobre o povoamento da Austrália trazem uma luz para explicar tal discrepância. Primeiramente, Brace afirma que as populações australianas constituem-se de um "tipo" humano absolutamente distinto e extremamente robusto, chegando a asugerir que o Homo sapiens seja separado em moderno e arcaico, sendo o arcaico o tipo robusto presente até Pleistoceno tardio (Brace et al., 1984). Essa redução do tamnho dentário teria se iniciado no Pleistoceno a uma taxa de $1 \%$ a cada 2.000 anos e teria chegado a $1 \%$ a cada 1.000 anos no Holoceno (Brace et al., 1987). Essa alteração no tipo humano teria ocorrido durante o Pleistoceno final por conta de um relaxamento na pressão evolutiva ou uma pressão seletiva diferenciada sobre a dentição em decorrencia da alteração dos padrões de dietas e preparação de alimentos e em um segundo momento já no Holoceno, da domesticação de vegetais e animais, reduzindo sistematicamente o tamanho dentário (Brace et al., 1984). Tal alteração teve origem nas regiões mais ao norte do globo, e não teria ocorrido nas regiões mais isoladas ao sul (como a Austrália), produzindo, consequentemente, diferentes padrões evolutivos nas populações humanas do norte em relação às do sul, já no Pleistoceno tardio (Brace et al., 1987). Com a expansão das populações do norte em direção ao sul, teria existido uma mistura dos dentes menores com os robustos mais isolados, e então, a difusão da redução dentária é notável em um gradiente norte-sul, sendo as populações do norte com os menores dentes e a região sul com maior robustez dentária (com a expressão máxima da robustez nas populações australianas) (Brace et al., 1971, 1980, 1984, 1987 e 2001). Tendo em vista esse isolamento 
dentário singular e a manutenção da robustez pleistocênica australiana, é esperado, portanto, que nenhuma outra dentição humana assemelhasse-se à australiana. Considerando a difusão das populações humanas e o gradiente dentário, as populações do Sudeste Asiático seriam os ancestrais das populações australo-melanésicas, e portanto, a associação dos paleoíndios de Lagoa Santa com as populações do Sudeste Asiático e da Polinésia poderia ser facilmente entendida, já que o isolamento australiano tem uma história evolutiva única. $E$, consequentemente, o padrão anterior não-especializado dentário, estaria representado pelas populações do Sudeste Asiático, condizente também com o padrão não-métrico sundadôntico, e portanto, um padrão morfo-dentário generalizado. Correlacionando os resultados aqui obtidos com dados craniométricos, temos portanto, uma confluência com as afirmações de Neves e associados ao associar os paleoíndios de Lagoa Santa com as populações de morfologia generalizada.

No que diz respeito à associação aqui obtida entre as populações nativas americanas tardias e as demais populações mundiais, é possível confirmar uma posição peculiar destes ameríndios como um conjunto populacional coeso, distante das demais populações mundiais e com grande variabilidade interna. Quadros semelhantes já foram gerados com base no DNA (Hammer \& Zegura, 2002; Rosenberg et al., 2002; Underhill et al., 2001), em craniometria (Howells, 1973; Neves \& Hubbe, 2005 e González-José et al., 2008) e, em morfologia dentária (Powell, 1996 e Hanihara \& Ishida, 2005). Os nativos americanos tardios 
apresentam dentes consideravelmente grandes e lateralizados (principalmente os dentes anteriores).

A afinidade entre as populações peri-mediterrânicas entre si - européias, norte-africanas e do Oriente Médio -, assim como a forte associação entre as populações asiáticas - nordeste, leste e sudeste - aqui reveladas também estão de acordo com trabalhos anteriores baseadas em dados de origens diversas (Hahinara, 1996; Underhill, et al. 2001; Hammer \& Zegura, 2002; Rosenberg et al., 2002; Hanihara \& Ishida, 2005). As populações européias e asiáticas são as populações mundiais com os menores dentes. Em alguns trabalhos, as populações nativas americanas tardias aproximam-se das européias (Howells, 1973; Brace \& Hunt 1990). Tal tendência mostrou-se aqui presente apenas nas análises baseados em Distâncias de Mahalanobis para a parcela masculina, quando somente "forma" foi levada em consideração.

Para a questão do povoamento da América em si, os resultados aqui relatados têm conseqüências que merecem uma reflexão mais detida. Primeiramente, é necessário esclarecer que com dados odontométricos não é possível definir a antiguidade do povoamento, uma suposta parada na Beríngia, nem tampouco rotas migratórias para a entrada dos humanos no Novo Mundo. Entretanto, a diferença acentuada entre os paleoíndios de Lagoa Santa e os demais nativos americanos impõe restrições a diversas hipóteses muito difundidas na literatura sobre o assunto. 
É óbvio que a homogeneidade dentária americana não se sustenta à luz dos dados odontométricos, como defendido pelo Modelo das Três Migrações (Greenberg et al., 1986) e por diversos trabalhos de Biologia Molecular (Torroni et al., 1992; Merriwether et al., 1995; Pena et al., 1995; Underhill et al., 1996; Forster et al., 1996; Bianchi et al., 1998; Starikovskaya et al., 1998, 2005; Santos et al., 1999; Silva et al., 2002). No entanto, alguns resultados gerados por geneticistas também têm apontado para uma grande diversidade biológica entre os nativos americanos, o que, em princípio, sugere o envolvimento de mais de uma leva migratória ou mais de uma população fonte no processo (Szathmary, 1993; Karafet et al., 1999; Schurr \& Sherry, 2004; Volodko et al., 2008).

O modelo integratado mais recente sobre a ocupação do Novo Mundo foi proposto por González-Jose et al. (2008). Eles defendem a idéia de um fluxo gênico contínuo para o Novo Mundo. No entanto, tal cenário é pouco provável à luz dos resultados deste estudo, já que o grau de diferenciação fenotípica apontada pelos dados odontométricos das populações nativas americanas, ao longo do tempo, é extremamente alto. Seria pouco provável que uma mesma população fonte apresentasse tamanha diversidade. A suposta hipervariabilidade sugerida por González-José et al. (2008) teria que ser maior do que a observada em todos os macro-agrupamentos regionais aqui utilizados; e em alguns casos, abarcar toda a diversidade fenotípica mundial.

Informações arqueológicas também vêm contribuindo para questionar a suposta homogeneidade das populações nativas americanas, sobretudo pela 
descoberta recente de vestígios mais antigos que Clovis e pela grande heterogeneidade da indústria lítica dos primeiros americanos, principalmente quando a América do Sul é levada em consideração (Prous, 1992, 2006; Meltzer et al., 1997; Dillehay, 1997, 1999, 2000, 2004; Adovasio et al., 1998; Kipnis, 1998; Goodyear, 1999; Neves et al., 1999; McAvoy et al., 2000; Dixon, 2001; Roosevelt et al. 2002, Collins, 2002; Lovgren, 2003; Miotti \& Salemme, 2003; Guidon et al., 2003; Bradley \& Stanford, 2004; Stanford et al., 2005, Araújo et al., 2006). A nãohomogeneidade da cultura material e a contemporaneidade entre sítios arqueológicos da América do Norte e do Sul falam a favor de uma entrada mais antiga na América, pelo menos anteriormente à estimada para a Cultura Clovis.

Um ponto primordial para a compreensão do povoamento do Novo Mundo diz respeito a condições climáticas e a possibilidades ecológicas de sustentação. A Beríngia já estaria exposta desde 60.000A.P. com o nível do mar aproximadamente 50 metros mais baixo que o atual, com total submersão da mesma pela elevação do nível do mar por volta de 10.000A.P. (Hoffecker et al., 1993). O sítio Yana RHS na Sibéria, datado em 28.000A.P., demonstra que os humanos já estavam adaptados a condições climáticas extremas muito antes do que se pensava até recentemente (Pitulko et al., 2004; Goebel et al., 2008) e estudos paleoclimáticos (Pavlov et al., 2001; Brubaker et al., 2005 Lydolph et al., 2005) vêm propondo que a Beríngia teria sustentado diversas populações vegetais e animais no período.

Entretanto, a expansão do homem na América, dependeu também de rotas de dispersão já no continente. O deslocamento para o sul por um corredor livre de 
gelo é compatível apenas com uma entrada mais tardia no continente (Wang et al., 2008), excluíndo a possibilidade de um povoamento anterior à Clovis. No entanto, alguns pesquisadores vêm defendendo uma rota costeira para a entrada e a dispersão inicial do homem no Novo Mundo o que teria permitido uma ocupação anterior à suposta abertura do corredor livre de gelo, impondo restrições menos extremas à expansão dos primeiros americanos (Fladmark, 1979; Dillehay, 1997, 1999; Dixon, 2001; Fix, 2002; Kelly, 2003; Elias, 2001; Mandrik et al., 2001; Fix, 2002; Surovell, 2003; Kelly, 2003; Schurr \& Sherry, 2004; Jantz \& Owsley, 2005; Fagundes et al., 2008a).

Em resumo, não é mais possível continuar caracterizando a ocupação primeira do Continente Americano como um evento de migração simples, direta e tardia, com apenas uma fonte populacional no Nordeste Asiático. Algumas informações geradas por este trabalho reforçam um cenário mais complexo, tendo em vista a grande diferenciação morfo-dentária das populações nativas americanas tardias/atuais em relação aos primeiros americanos e uma associação recorrente entre a população antiga de Lagoa Santa e populações com morfologia dentária generalizada, sobretudo com as do Sudeste Asiático e da Polinésia. 


\section{Referências Bibliográficas}

Achilli, A., Perego, U.A., Bravi, C.M., Coble, M.D., Kong, Q.P., Woodward, S.R., Salas, A., Torroni, A \& Bandelt, H.J. 2008. The phylogeny of the four pan-american mtDNA haplogroups: implications for evolutionary and disease studies. PloS ONE 3: 1-8, e1764.

Adovasio, J.M., Pedler, D.R., Donahue, J. \& Stuckenrath R. 1998. Two decades of debate on Meadowcroft Rockshelter. North American Archaeology, 19(4): 317-341.

Alvesalo, L. \& Tigerstedt, P. M. A. 1974. Heritabilities of human tooth dimensions. Hereditas, 77: 311318.

Araújo, A.G.M., Pilo, L.B., Neves, W.A. \& Atui, J.P. 2006. Human occupation and paleoenvoronments in South America: expanding the notion of na "archaic gap". Rev. do MAE, 15-16: 3-35.

Baillet, G., Rothhamer, F., Carnese, F.R., Bravi, C.M. \& Bianchi, N.O. 1994. Founder mitochondrial haplotypes in Amerindian population. Am. J. Hum. Genet., 54: 27-33.

Bailey, S.E. 2002. A closer look at Neanderthal postcanino dental morphology. I The mandibular dentition. The Anatom. Record. (New Anat.), 269: 148-156.

Bailey, S.E. 2004. A morphometric analysis of maxillary molar crowns of Middle-Late Pleistocene hominids. J. Hum. Evol., 47: 183-198.

Bailey, S.E. \& Lynch, J.M. 2005. Diagnostic differences in mandibular P4 shape between Neandertals and anatomically modern humans. Am. J. Phys. Anthropol., 126: 268-277.

Bailey, S.E.; Pilbrow, V.C.; Wood, B.A. 2004. Interobserver error involved in independent attempts to measure cusp base areas of Pan M1s. J. Anat., 205: 323-331.

Bailey, S.E. \& Turner II, G.C. 1999. A new look at some old teeth: an analysis of non-metric dental traits in Neandertals and Old World modern humans. Am. J. Phys. Anthropol., 27: 86.

Bailey, S.E. \& Wood, B.A. 2007. Trends in postcanine occlusal morphology within the the hominin clade: the case of Paranthropus. In.: S.E. Bailey \& J.J. Hublin (eds.) Dental perspective on human evolution: state of the art research in dental paleoanthropology. Springer: Dordrecht. Pp. 3-8.

Bandelt, H.J., Herrnstad, C., Yao, Y.G., Kong, Q.P., Kivisild, T., Rengo, C., Scozzari, R., Richards, M., Vilems, R., Macaulay, V., Howell, N., Torroni, A. \& Zhang, Y.P. 2003. Identification of native american founder mtDNAs through the analysis of complete mtDNA sequences: some cavets. Ann. Hum. Genet., 67: 512-524.

Bermudez-de-Castro, J.M., Martinón-Torres, M., Carbonell, E., Sarmiento, S., Rosas, A., van der Made, J. \& Lozano, M. 2004. The Atapuerca sites and their contribution to the knowledge of human evolution in Europe. Evol. Anthropol., 13: 25-41.

Barrett, M.J.; Brown, T. \& Macdonald, M.R. 1963. Dental observations on Australian aborigines: mesiodistal crown diameters of permanente teeth. Australian Dental Journal, 8: 150-155. 
Barrett, M.J.; Brown, T.; Arato, G. \& Ozols, I.V. 1964. Dental observation on Australian aborigines: buccolingual crown diameters of deciduous and permanet teeth. Australian Dental Journal, 9: 280285.

Berry, A.C. 1976. The Anthropological value of minor variants of the dental crown. Am. J. Phys. Anthropol., 45: 257-268.

Bianchi, N.O., Catanesi, C.I., Baillet, G., Martinéz-Marignac, V.M., Bravi, C.M., Vidal-Rioja, L.B., Herrera, R.J. \& López-Camelo, J.S. 1998. Characterization of an ancestral derived Y-chromosome haplotypes of New World native populations. Am. J. Hum. Genet., 63: 1862-1871.

Black III, T.K. 1978. Sexual dimorphism in the tooth-crown diameters of the deciduos teeth. Am. J. Phys. Anthropol., 48: 77-82.

Blum, M. \& Neves, W.A. 1999. O "Modelo dos dois componentes principais": sua inserção nos eventos expansionistas do final do Pleistoceno e suas implicações para a origem do Homo sapiens. O Carste, 14(1): 42-49.

Blum, M.; Neves, W.A. \& Lahr, M. 2001. The long and winding road of the first americans. Curr. Res. in the Pleistocene, 18: 69-72.

Boas, F. 1912. New evidence in regard to the instability of human types. Am. Antiquity, 14: 530-562.

Bolnick, D.A.; Shook, B.A.; Campbell, L. \& Goddard, I. 2004 Problematic Use of Greenberg's Linguistic Classification of the Americas in Studies of Native American Genetic Variation. Am. J. Hum. Genet. 75:519-523, 2004

Bonatto, S.L. \& Salzano, F.M. 1997a. Diversity and age of the four major mtDNA haplogroups, and their implications for the peopling of the New World. Am J. Hum. Genet., 61: 1413-1423.

Bonatto, S.L. \& Salzano, F.M. 1997b. A single and early migration for the peopling of the Americas supported by mitochondrial DNA sequence data. Proc. Nat. Acad. Scie., 94: 1966-1971.

Bortoloni, M., Salzano, F.M., Bau, C.H.D., Layrisse, Z., Petzl-Erler, M.L., Tsuneto, L.T., Hill, K., Hurtado, A.M. Castro-de-Guerra, D., Bedoya, G. \& Ruiz-Linares, A. 2002. Y-chromossome biallelic polymorphisms and native americans population structure Ann. Hum. Genet., 66: 255-259.

Bortoloni, M., Salzano, F.M., Thomas, M.G., Stuart, S., Nasanen, S.P.K. Baú, C.H.D., Hutz, M.H., Layrisse, Z., Petzl-Erler, M.L., Tsuneto, L.T., Hill, K., Hurtado, A.M., Castro-de-Guerra, D., Torres, M.M., Groot, H., Michalski, R., Nymadawa, P., Bedoya, G., Brandman, N., Labuda, D \& Ruiz-Linares, A. 2003. Y-chromossome evidence for differing ancient demographic histories in the Americas. Am. J. Hum. Genet., 73: 524-539.

Brace, C.L. 1967. Environment, tooth form, and size in the Pleistocene. J. Dent. Res. Supp. 5, 46: 809-816.

Brace, C.L. \& Mahler, P.E. 1971. Post-Pleistocene changes in the Human dentition. Am. J. Physical Anthropol., 34: 191-204.

Brace, C.L. 1980. Australian tooth-size clines and the death of a stereotype. Curr. Anthropol., 21: 
141-164.

Brace, C.L. \& Ryan, A.S. 1980. Sexual dimorphism and human tooth size differences. J. Hum. Evol., 9: 417-435.

Brace, C.L. \& Nagai, M. 1982. Jaaponese tooth size: past and present. Am. J. Phys. Anthropol., 59: 399-411.

Brace, C.L.; Xiang-qing, S. \& Zhen-biao, Z. 1984. Prehistoric and modern tooth size in China. In.: f.H. Smith \& F. Spencer (eds) The origins of Modern Humans: a world survey of the fossil evidence. New York, Liss. pp. 485-516.

Brace, C.L., Rosenberg, K.R. \& Hunt, K.D. 1987. Gradual change in human tooth size in the late pleistocene and post-pleistocene. Evolution, 41: 705-720.

Brace, C.L. \& Hunt, K.D. 1990. A nonracial craniofacial perspective on human variation: A(ustralia) to Z(uni). Am. J. Phys. Anthropol., 82: 341-360.

Brace, C.L., Nelson, A.R., Seguchi, N., Oe, H., Sering, L., Qifeng, P., Yongyi, L. \& Tumen, D. 2001. Old World source of the first New World human inhabitants: a comparative craniofacial view. Proc. Nat. Acad. Scie., 98(17): 10017-10022.

Bradley, B. \& Stanford, D. 2004. The North American Atlantic ice-edge corridor: a possible Paleolithic route to New World. World Archaeol., 36(4): 459-478.

Braga, J. \& Heuze, Y. 2007. Quantifying variation in human dental development sequences: an EVODEVO perspective. In.: SE Bailey \& JJ Hublin (eds.) Dental perspective on human evolution: state of the art research in dental paleoanthropology. Springer: Dordrecht. pp. 247-261.

Brown, M.; Hosseini, S.; Torroni, A.; Bandelt, H.; Allen, J.; Schurr, T.; Scozzari, R.; Cruciani, F.; Wallace, D. 1998. mtDNA Haplogroup X: An Ancient Link between Europe/Western Asia and North America? Am. J. Hum. Genet., 63(6): 1852-1861.

Brubaker, L.B.; Anderson, P.M.; Edwards, E.M. \& Lozhkin, A.V. 2005. Beringia as a glacial refugium for boreal trees and shrubs: new perspectives from mapped pollen data. J. Biogeog., 32(5): 833848.

Bryan, A.L. 1969. Early man in American and the late Pleistocene chronology of western Canada and Alaska, Current Anthropol., 10: 339-365.

Calcagno, J.M. \& Gibson, K.R. 1988. Human dental reduction: natural selection or the probable mutation effect. Am. J. Phys. Anthropol. 77, 505-517.

Callegari-Jacques, S.M. \& Salzano, F.M. 1989. Genetic variation within two linguistic Ameridian groups - relationship with geography and population size. Am. J. Phys. Anthropol., 79: 313-320.

Campbell, L. 1988. [Review of Language in the Americas, Greenberg 1987]. Language, 64: 591-615.

Campbell, L. 1997. American Indian languages: The historical linguistics of Native America. New York: Oxford University Press.

Cann, R.L. 1994. mtDNA and Native Americans: a southern perspective. Am. J. Hum. Genet., 55: 7- 
11.

Cardoso, H.F.V. 2007. Environmental effects on skeletal versus dental development: using a documented subadult skeletal sample to test a basic assumption in human osteological research. Am. J. Phys. Anthropol., 132: 223-233

Cardoso, H.F.V. 2008. Sample-specific (universal) metric approaches for determining the se of immature human skeletal remains using permanent tooth dimensions. J. Archaeol. Scie., 35: 158168.

Cavalli-Sforza, L.L., Piazza, A., Menozzi, P. \& Mountains, J. 1988. Reconstruction of human evolution: bringing together genetic, archaeological and linguistic data. Proc. Nat. Acad. Scie., 85: 6002-6006.

Cavalli-Sforza, L.L., Piazza, A. \& Menozzi, P. 1994. History and geography of genes. Princeton: Princeton University Press.

Cheverud, J.M. 1982. Phenotypic, genetic, and environmental morphological integration in the cranium. Evolution 36:499-516.

Collins, M.B. 2002. The Gault site, Texas, and Clovis research. Athena Review, 3(2): 31-41.

Corruccini, R. S. 1973. Size and shape in similarity coefficients based on metric characters. Am. J. Phys. Anthrop., 38: 743-754.

Cunningham, D.L. \& Jantz, R. 2003. The morphometric relationship of the Upper Cave 101 and 103 to modern Homo sapiens. J. Hum. Evol., 43: 1-18.

Dahlberg, A.A. 1945. The changing dentition of man. J. of the American Dental Association, 32: 676690.

Demirjian, A., Buschang, P.H., Tanguay, R. \& Patterson, D.K. 1985. Interrelationship among measures of somatic, skeletal, dental and sexual maturity. Am. J. Orthod., 88: 433-438.

Dempsey, P.J \& Townsend, G.C. 2001. Genetic and environmental contributions to variation in human tooth size. Heredity, 86: 685-693.

Derbeneva, O.A.; Sukernik, R.I.; Volodko, N.V.; Hosseini, S.H.; Lott, M.T. \& Wallace, D.C. 2002. Analysis of the miutocondrial DNA diversity in the Aleuts of the commander islands and its implications for the Genetic history of Beringia. Am. J. Hum. Genet., 71: 415-421.

Dillehay, T.D. 1997. Monte Verde: a late Pleistocene settlement in Chile 2: the archaeological context. Washington: Smithsonian Institution Press.

Dillehay, T.D. 1999. The Late Pleistocene Cultures of South America. Evolutionary Anthropology, 7: 206-216.

Dillehay, T.D. 2000. The settlement of the Americas: a new prehystory. New York: Basic Books Press.

Dillehay, T. D. 2003. Tracking the first Americans. Nature, 425: 23-24.

Dillehay, T.D. 2004. Monte Verde: un asentamiento humano del Pleistoceno tardio em sur Del Chile. Santiago: Lom Ediciones.

Dillehay, T.D., Ramírez, C., Pino, M., Collins, M.B., Rossen, J. \& Pino-Navarro, J.D. 2008. Monte 
Verde: seaweed, food, medicine, and peopling of south America. Science, 320: 784-789.

Dixon, E.J. 1999. Bones, Boats and Bison: Archeology and the First Colonization of Western North America. Albuquerque: University of New México Press.

Dixon, E.J. 2001. Human colonization of the Americas: timing, technology and process. Quart. Sci. Rev., 20: 277-299.

Elias, S.A. 2001. Beringian paleoecology: results from the 1997 workshop. Quat. Scie. Rev., 20: 7-13.

Eshleman, J.A., Malhi, R.S. \& Smith, D.G. 2003. Mitochondrial DNA studies of native americans: comceptions and misconception of the population prehistory of the Americas. Evol. Anthropol., 12: 7-18.

Fagan, B.M. 1987. The great journey. London: Thames and Hudson Ltda.

Fagan, B.M. 1999. World prehistory - a brief introduction. Menlo Park: Longman.

Fagundes, N. J. R., Ray, N., Beaumont, M., Neuenschwander, S., Salzano, F. M., Bonatto, S. L. \& Excoffier, L. 2007. Statistical evaluation of alternative models of human evolution. Proc. Nat. Acad. Scie., 104: 17614-17619.

Fagundes, N.J.R.; Kanitz, R.; Eckert, R.; Valls, A.C.S; Bogo, M.R.; Salzano, F.M.; Smith, D.G.; Silva Jr., W.A.; Zago, M.A.; Ribeiro-dos-Santos, A.K.; Santos, S.E.B.; Petzl-Erler, M.L. \& Bonatto, S.L. 2008a. Mitochondrial Population Genomics Supports a Single Pre-Clovis Origin with a Coastal Route for the Peopling of the Americas. Am. J. Hum. Genet., 82: 583-592.

Fagundes, N.J.R.; Kanitz, R. \& Bonatto, S.L. 2008b. Reply to: Ho, S.Y.W. \& Endicott, P. 2008. The crucial role of calibration in molecular date estiamtes for the peopling of the Americas. Am. J. Hum. Genet., 83:146-147.

Fix, A.G. 2002. Colonization models and initial genetic diversity in the Americas. Hum. Biol., 74(1): 110.

Fladmark, K.R. 1979. Routes: alternate migration corridors for early man in North America. American Antiquity, 4(1): 55-69.

Forster, P., Hardling, R., Torroni, A. \& Bandelt, H. J. 1996. Origin and evolution of native American mtDNA variation: a reppraisal. Am. J. Hum. Genet., 59: 935-945.

Gran, S.M.; Lewis, A.B. \& Kerewsky, R.S. 1964. Sex difference in tooth size. J. Dental Research, 43: 306.

Garn, S.M.; Lewis, A.B. \& Kerewsky, R.S. 1965. X-linked inheritance of tooth size. J. Den. Res, 44: 439-441.

Garn, S.M.; Brace, C.L. \& Cole, P.E. 1967. Use of crown areas in odontometric analyses. J. Den. Res., 56: 876 .

Garn, S.M., Lewis, A.B. \& Kerewsky, R.S. 1968a. Relationship Between Buccolingual and Mesiodistal Tooth Diameters. J. Dent. Res. 47: 495.

Garn, S.M., Lewis, A.B. \& Walenga, A.J. 1968b. Two-generation confirmation of crown-size body-size 
relationships in human beings. J. Dent. Res., 47(6): 1197.

Garn, S.M., Lewis, A.B. \& Kerewsky, R.S. 1968c. The magnitude and implications of the relationship between tooth size and body size. Arch. Oral Biol., 13: 129-131.

Gibbons, A. 1993. Geneticists trace the DNA trail of the first Americans. Science, 259: 312-313.

Gibbons, A. 1996. The peopling of the Americas. Science, 274: 31-33.

Goddard, I. 1987. [Review of Joseph Greenberg, Language in the Americas]. Current Anthropology, 28: 656-657.

Goddard, I. 1990. [Review of Language in the Americas by Joseph H. Greenberg]. Linguistics, 28: 556-558.

Goddard, I. 1996. The classification of native languages of North America. In I. Goddard (Ed.), Languages (pp. 290-323). Handbook of North Americans Indians (Vol. 17). Washington, D. C.: Smithsonian Institution.

Goddard, I. \& Campbell, L. 1994. The history and classification of American Indian languages: What are the implications for the peopling of the Americas?. In R. Bonnichsen \& D. Steele (Eds.), Method and theory for investigating the peopling of the Americas. pp. 189-207. Corvallis, OR: Oregon State University.

Goebel, T. 1999. Pleistocene human colonization of Siberia and peopling of the Americas: an ecological approach. Evol. Anthropol., 8(6): 208-227.

Goebel, T.; Waters, M.R. \& Dikova, M. 2003. The archaeology of Ushuki Lake, Kamchatka, and the Pleistocene peopling of the Americas. Science, 301: 501-505.

Goebel, T. 2008. The late Pleistocene dispersal of Modern humans in the Americas. Science, 319: 1497-1502.

González-José, R., Dahinten, S.L.; Luis, M.A.; Hernández, M. \& Pucciarelli, H.M. 2001. Craniometric variation and the settlement of the Americas: testing hypotheses by means of R-matrix and matrix correlation analyses. Am. J. Phys. Anthropol., 116: 154-165.

González-José, R., González-Martin, A., Hernández, M., Pucciarelli, H.M., Sardi, M., Rosales, A.S. \& van de Molen, S. 2003. Craniometric evidence for paleoamerican survival in Baja California. Nature, 452: 62-65.

González-José, R., Neves, W.A., Lahr, M.M., González, S., Pucciarelli, H.M., Martinez, M.H. \& Correal, U. 2005. Late Pleistocene/Holocene craniofacial morphology in Mesoamerican Paleoindians: implications for the peopling of the New World. Am. J. Phys. Anthrop., 128: 772-780.

González-José, R.; Martínez-Abadías, N.; González-Martín, A.; Neves, W.; Pucciarelli, H.M. \& Hernández, M. 2006. Análisis morfogeométrico de cuatro cráneso antiguos del Valle de México: Peñón III, Metro Balderas, Chimalhuacán y Cueva Del Tecolote. Chicuilco, 13(37): 105-127.

González-José, R., Bortoloni, M. C., Santos, F. R. \& Bonatto, S. L. 2008. The peopling of America: craniofacial shape variation on a continental scale and its interpretation from an interdisciplinary 
view. Am. J. Phys. Anthropol. Published Online: 14 Maio, DOI: 10.1002/ajpa.20854

Goodyear, A.C.III 1999. The Early Holocene occupation of the Southeastern United States: a geoarchaeological summary. In: Bonnichsen, K., L. \& Turnmire, K., L. Corvallis: Cent. Study First Americans.

Greenberg, J.H., Turner II, C.G. \& Zegura, S.L. 1986. The settlement of the Americas: a comparison of linguistic, dental and genetic evidence. Curr. Anthropol., 27: 477-497.

Guatelli-Steinberg, D.; Sciulli, P.W. \& Betsinger, T.K. 2008. Dental crown size and sex hormone concentrations: another look at the development of sexual dimorphism. Am. J. Phys. Anthropol., 137: 324-333.

Guidon, N. \& Delibrias, G. 1996. Carbon-14 dates point to man in the Americas 32,000 years ago. Nature 321, 269-271.

Guidon, N.; La Salvia, E.S.; Maranca, S. \& Baffa Filho, O. 2003. Some evidence of a date of first humans to arrive in Brazil. J. Archaeol. Scie., 30: 351-354.

Hair, J.F.; Anderson, R.E.; Tatham, R.L. \& Black, W.C. 2005. Análise Multivarada de dados. Porto Algre: Artmed Editora S.A.

Hanihara, K. 1967. Racial characteristics in the dentition. J. Dent. Res., Supp. 5: 923-926.

Hanihara, K. 1976. Statistical and comparative studies of the australian aboriginal dentition. Bulletin of University of Tokyo no. 11.

Hanihara, K. 1977. Distances between australian aborigines and certain other populations based on dental measurements. J. Hum. Evol., 6: 403-418.

Hanihara, T. 1996. Comparison of Craniofacial Features of Major Human Groups. Am. J. Phys. Anthropol., 99: 389-412.

Hanihara, T \& Ishida, H. 2005. Metric dental variation of major human populations. Am. J. Phys. Anthropol., 128: 287-298.

Hanihara, T. 2008. Morphological variation of major human populations based on nonmetric dental traits. Am. J. Phys. Antropol., 136: 169-182.

Harris, M.B. \& Smith, S.D. 1983. The relationships of age, sex, ethnicity, and weight to stereotypes of obesity and self perception. Int. J. Obes., 7(4): 361-71.

Harris, E.F.; Smith, R.N.; Brace, C.L. \& Hinton 1983. On tooth size and oceanic prehistory. Curr. Antropol., 24: 243-246.

Harris, E.F. \& McKee, J.H. 1990. Tooth mineralization standards for blacks and whites from the middle southern United States. J. Forensic. Sci., 35(4): 859-72.

Harris, E.F. \& Sjøvold, T. 2004. Calculation of Smith's Mean Measure of Divergence for Intergroup Comparisons Using Nonmetric Data. Dental Anthropol., 17(3): 83-93.

Harris, E.F., Smith, R.N. 2008. According for measurement error: a critical but often overlooked process. Archieves of oral biology, In press. 
Haydenblit, R. 1996. Dental variation among four Prehispanic Mexican populations. Am. J. Phys. Anthropol., 100: 225-246.

Henderson, A.M. \& Corruccini, R.S. 1976. Relationships between tooth size and body size in american blacks. J. Dent. Res., 94-96.

Hey, J. 2005. On the Number of New World Founders: A Population Genetic Portrait of the Peopling of the Americas. PLoS Biology, 3(6): e193.

Heyer, E.; Zietkiewicz, E.; Rochowski, A.; Yotova, V.; Puymirat, J. \& Labuda, D 2001. Phylogenetic and familial estimates of mitochondrial substitution rates: study of control region mutations in deep-rooting pedigrees. Am. J. Hum. Genet., 69: 1113-1126.

Hillson, S. 1996. Dental Anthropology. Cambridge University Press.

Hlusko, L.J. 2004. Integrating the genotype and phenotype in hominid paleontology. Proced. Nac. Acad. Scie., 101(9): 2653-2657.

Ho, S.Y.W. \& Endicott, P. 2008. The crucial role of calibration in molecular date estiamtes for the peopling of the Americas. Am. J. Hum. Genet., 83:142-146.

Hoffecker, J.F., Powers, W.R. \& Goebel, T. 1993. The colonization of Beringia and the peopling of the New World. Science, 259: 46-53.

Hoffecker, J.F. \& Elias, S.A. 2003. Enviromment and archaeology in Beringia. Evol. Anthropol., 12: 34-49.

Horai, S.; Kondo, R.; Nakagawa-Hattori, Y.; Hayashi, S.; Sonoda, S. \& Tajima, K. 1993. Peopling of the Américas, founded by four major lineages of mitocondrial DNA. Mol. Biol. Evol., 10(1): 23-47.

Howells, W.W. 1973. Cranial variation in man. A study by multivariate analysis of patterns of difference among recent human populations. Papers of Peabody Museum of Archaeology and Ethnology. Cambridge: Harvard University Press.

Howells, W.W. 1989. Skull shapes and the map. Craniometric analysis in the dispersion of modern Homo. Papers of Peabody Museum of Archaeology and Ethnology. Cambridge: Harvard University Press.

Hrdlička, A. 1907. Skeletal remains suggesting or attributed to early man in North America. Washington, DC: Government Printing Office.

Hrdlička, A. 1912. The skeletal remains of early man in South America. In: Hrdlicka, A. (editor). Early man in South America. Washington: Bureau of American Ethnology Bulletin 52. Smithsonian Institution, 153-185.

Hrdlička, A. 1932. The coming of man from Asia in light of recent discoveries. Proc. Am. Philos. Soc. 71, 393-402.

Hubbe, M.; Neves, W.A. Atuí, J.P.; Cartelle, C. \& Silva, M.A.P. 2004. A new early human skeleton from Brazil: support for the "Two main biological components model" for the settlement of the Americas. Curr. Res. in the Pleistocene 21:77-81. 
Hubbe, M.; Neves, W.A.; Amaral, H.L. \& Guidon, N. 2007. "Zuzu" strikes again - Morphological affinities of the Early Holocene human skeleton from Toca dos Coqueiros, Piauí, Brazil. Am. J. Phys. Anthropol., 134(2): 285-291.

Imbelloni, J. 1938. Tabla classificatoria de los indios. Regiones biológicas y grupos raciales humanos de América. Physis, 12: 229-249.

Irish, J.D. 1994. The African dental complex: diagnostic morphological variants of modern subsaharan populations. Am. J. Phys. Anthropol., Suppl. 18: 112.

Irish, J.D. 1997. Characteristic high- and low-frequency dental traits in sub-saharan African populations. Am. J. Phys. Anthropol., 102: 455-467.

Irish, J.D. 1998. Ancestral dental traits in recent sub-saharan Africans and the orign of modern humans. J. Hum. Evol., 34: 81-98.

Irish, J.D. \& Guatelli-Steinberg, D. 2003. Ancient teeth and modern human origins: an expanded comparison of Africa Plio-Pleistocene and recent world dental samples. J. Hum. Evol., 45: 113-144.

Jantz, R.L. \& Owsley, D.W. 2001. Variation among early North America crania. Am. J. Phys. Anthropol., 114: 146-155.

Jantz, R.L. \& Owsley, D.W. 2005. Circumpacifica populations and the peopling of the New World: evidence from cranial morphometric. In.: R. Bonnichsen, B.T. Lepper, D. Stanford \& M.R. Waters (eds.) Paleoamerican origins: beyond Clovis. College Station: Texas A\&M University Press.

Jernevall, J. \& Jung, H.S. 2000. Genotype, phenotype and developmental biology of molar tooth characters. Yearb. Phys. Anthropol., 43: 171-190.

Jung, H.S.; Hitoshi, Y. \& Kim, H.J. 2003. Study on tooth development, past, present, and future. Microsc. Res. Techn., 60(5): 480-482.

Kamminga, J. \& Wright, R.V.S. 1988. The Upper Cave Zhoukoudian and the origins of the Mongoloids. J. Hum. Evolution, 17: 739-767.

Karafet, T.M., Zegura, S.L., Posukh, O., Osipova, L., Bergen, A., Long, J., Goldman, D., Klitz, W., Harihara, S., Knijff, P., Wiebe, V., Griffiths, R. C., Templeton, A.R. \& Hammer, M.F. 1999. Ancestral Asian source(s) of New World Y-chromossome founder haplotypes. Am. J. Hum. Genet., 64: 817831.

Kelly, R.L. 2003. Maybe we do know when peoplo frist came to North America; and what does it means if we do? Quaternary International, 109-110:133-145.

Kemp, B.M.; Malhi, R.S.; McDonough, J.; Bolnick, D.A.; Eshleman, J.A.; Rickards, O.; MartinezLabarga, C.; Johnson, J.R.; Lorenz, J.G.; Dixon, E.J.; Fifield, T.E.; Heaton, T.H.; Worl, R. \& Smith, D.G. 2007. Gentic analisys of early Holocene Skeleteal remains froma Alaska and its implications for the settlement of the Americas. Am. J. Phys. Anthropol., 132: 605-621.

Kieser, J.A. 1990. Human adult odontometrics: the study of variation in adult tooth size. Cambridge: Cambridge University Press. 
Kieser, J.A. \& Groeneveld, H.T. 1998. Fluctuating dental asymmetry and prenatal exposure to tobacco smoke. In:Lukacs, J.R. (ed.) Human dental development, morphology and pathology: Atribute to Albert A. Dahlberg. University of Oregon Anthropology Paper, 54: 287-297.

Kipnis, R. 1998. Early hunter-gatheres in the Americas: perspectives form central Brazil. Antiquity, 72: 581-592.

Kirk, R.L. 1979. Genetic differentiation in Australia and its bearing on the origin of the first Americans. In: Laughlin, W. S. \& Harper, A. B. (eds). The first Americans: origins, affinities and adaptations. Stuttgart: Gustav Fischer, pp. 211-237.

Kitchen, A.; Miyamoto, M.M. \& Mulligan, C.J. 2008. A three-stage colonization model for the peopling of the Americas. PLoS One, 3(2): e1596.

Kondo, S.; Townsend, G.C. \& Yamada, H. 2005. Sexual dimorphism of cusp dimensions in human maxillary molars. Am. J. Phys. Anthropol., 128:870-877.

Kurtén, B. 1967. Some quantitative approaches to dental microevolution. J. Dent. Res. Suppl. 3: 817828.

Lahr, M.M. 1995. Patterns of modern human diversification: implications for Amerindian origins. Yearb. Phys. Anthrop., 38: 163-198.

Larsen, C.S. 1997. Bioarchaeology: Interpreting behavior from the human skeleton. Cambridge University Press.

Lell, J.T., Sukernik, R.I., Starikovskaya, Y.B., Su, B., Jin, L., Scurr, T.G., Underhill, P.A. \& Wallace, D. C. (2002). The dual origin and siberian affinities of native american $Y$ chromossomes. Am. J. Hum. Genet., 70: 192-206.

Lewis, D.W. \& Grainger, R.M. 1967. Sex-linked inheritance of tooth size: a family study. Archs. Oral Biol., 12: 539-544.

Lovgren, S. 2003. Who were the first americans? National Geografic News, September 3, 2003. on line version: <http://news.nationalgographic.com/news/2003/09/0903_030903_bajaskull.html> acessado em 05/11/2003.

Lund, H. 2001. Gender determination by odontometrics in Swedish population. J. Odontostomatol., 17(2): 30-34.

Lydolph, M.C.; Jacobsen, J.; Arctander, P.; Gilbert, M.T.P.; Gilichinsky, D.A.; Hansen, A.J.; Wilerslev, E. \& Lange, L. 2005. Beringian paleoecology inferred from permafrost-preserved fungal DNA. Applied and Environmental Microbiology, 71(2): 1012-1017.

Macchiarelli, R. \& Bailey, S.E. 2007. Introduction. . In.: S.E. Bailey \& J.J. Hublin (eds.) Dental perspective on human evolution: state of the art research in dental paleoanthropology. Springer: Dordrecht. pp. 139-146.

Manni, F.; Vargiu, R. \& Coppa, A. 2007. Neural Network analysis by using self-organizing maps (SOMs) applied to humam fossil dental morphology: a new methodology. In.: S.E. Bailey \& J.J. 
Hublin (eds.) Dental perspective on human evolution: state of the art research in dental paleoanthropology. Springer: Dordrecht. pp. 81-101.

Malhi, R.S. \& Smith, D.G. 2002. Brief Communication: Haplogroup X confirmed in prehistoric North America. Am. J. Phys. Anthropol., 119: 84-86.

Malhi, R.S.; Eshleman, J.A.; Greenberg, J.A.; Weiss, D.A.; Shook, B.A.S.; Kaestle, F.A.; Lorenz, J.G.; Kemp, B.M.; Johnson, J.R. \& Smith, D.G. 2002. The structure of diversity within New World mitocondrial DNA haplogroups: implications for the prehistory of North America.

Mandrik, C.A.S.; Josenhans, H.; Fedje, D.W. \& Mathewes, R.W. 2001. Late quaternary paleoenvironments of Northwestern North America: implications for inland versus costal migration routs. Quater. Scie. Rev., 20: 301-314.

Matson, G. A., Sutton, H. E., Echeverry, R., Swanson, J. \& Robinson, A. 1967. Distribution of hereditary blood groups among Indians in South America. Am. J. Phys. Anthropol., 27: 157-193.

Matsumura, H. \& Hudson, M.J. 2005. Dental Perspectives on the population history of southeast Asia. Am. J. Phys. Anthropol., 127:182-209.

McAvoy, J.M., Baker, J.C., Feathers, J.K., Hodges, R.L. \& McWeeney, L.J. 2000. Summary of research at the Cactus Hill archaeological site, Sussex County, Virginia. National Geographic Society.

McKee, J.K. 1984. A genetic model of dental reduction through the probable mutation effect. Am. J. Phys. Anthropol., 65: 231-241.

Meltzer, D.J. 1989. Why don't we know when the frist people came to North America?. American Antiquity, 54(3): 471-490.

Meltzer, D.J., Grayson, D.K., Ardilla, G., Barker, A.W., Dincauze, D.F., Haynes, C.V., Mena, F., Núñez, L. \& Stanford, D.J. 1997. On the Pleistocene antiquity of Monte Verde, Southern Chile. Am. Antiquity, 62: 659-663.

Mena, F., Reyes, O. Stafford Jr, T.W. \& Southon, J. 2003. Early human remains from Baño Nuevo-1 cave, central Patagonian Andes, Chile. Quat. Int., 109; 113-121.

Merriwether, D.A.; Rothhammer, F. \& Ferrel, R.E. 1995. Distribution of the four founding lineage haplotypes in native Americans suggests a single wave of migration for the New World. Am. J. Phy. Anthropol., 98: 411-430.

Miotti, L., Salemme, M. \& Rabassa, J. 2003. In: Ancient Evidence for Paleo-South Americans: From Where the South Winds Blow, L. Miotti, M. Salemme, N. Flegenheimer (eds) Center for the Study of First Americans and Texas A\&M University, pp. 99-104.

Mithun, M. 1999. The languages of Native North America. Cambridge: Cambridge University Press.

Moggi-Cecchi, J. \& Boccone, S. 2007. Maxillary molars cusp morphology of South African australopithecines. In.: S.E. Bailey \& J.J. Hublin (eds.) Dental perspective on human evolution: state of the art research in dental paleoanthropology. Springer: Dordrecht. pp. 53-64.

Moorrees, C.F.A., Thomsen, S.O., Jensen, E. \& Yen, P.K. 1957. Mesiodistal crown diameters of the 
deciduos and permanent teeth in individuals. J. Dent. Res., 36(1): 39-47.

Moorrees, C.F.A. \& Reed, R.B. 1964. Correlations among crown diameters of human teeth. Arch. Oral Biol., 9: 685-697.

Morris, D.H. 1986. Maxillary molar occlusal polygons in five human samples. Am. J. Phys. Anthropol., 70: 333-338.

Munford, D., Zanini, M.C., \& Neves, W.A. 1995. Human cranial variation in South America: implications for the settlement of the New World. Braz. J. Genet., 18: 673-688.

Munford, D. 1999. Estudo Comparado da Morfologia Craniana de Populações Pré-Históricas da América do Sul: Implicações para a Questão do Povoamento do Novo Mundo. [dissertação] São Paulo: Departamento de Biologia, Instituto de Biociências, Universidade de São Paulo.

Neves, W.A. \& Atuí, J.P. 2004a. O mito da homogeneidade biológica na população paleoíndia de Lagoa Santa: implicações antropológicas. Rev. USP, 47(1): 159-206.

Neves, W.A.; Bernardo, D.V. \& Okomura, M.M.M. 2007a. A origem do homem americano vista a partir da América do Sul: uma ou duas migrações?. Rev. Antropol., 50(1): 9-44.

Neves, W.A. \& Blum, M. 1998. Afinidades biológicas entre populações pré-históricas do centro-sul brasileiro: uma análise multivariada. Fronteiras: Revista de História da UFMS, 2(4): 143-169.

Neves, W.A. \& Blum, M. 2000. The buhl burial: a comment on Green et al. Am. Antiquity, 65(1): 191193.

Neves, W.A. \& Blum, M. 2001. "Luzia" is not alone: further evidence of a Non-mongoloid settlement of the New World. Curr. Res. Pleist., 18: 73-77.

Neves, W.A. \& Blum, M. 2002. Morfologia craniana da população paleoíndia de Lagoa Santa: implicações para a questão do povoamento da América. CRONOS: Rev. Hist., 6: 21-37.

Neves, W.A.; González-José, R.; Hubbe, M.; Kipnis, R.; Araújo, A.G.M. \& Blasi, O. 2004c. Early Holocene human skeletal remains from Cerca Grande, Lagoa Santa, Central Brazil, and the origins of the first Americans. World Archaelogy, 36(4): 479-501.

Neves, W.A.; Hubbe, M.; Ribeiro, A.P.M. \& Bernardo, D.V. 2004b. Afinidades morfológicas de três crânios associados à tradição Umbu: uma análise exploratória multivariada. Rev. Cepa, 28(39): 159-185.

Neves, W.A. \& Hubbe, M. 2005. Cranial morphology of early Americans from Lagoa Santa, Brazil: Implications for the settlement of the New World. Proc. Nat. Acad. Scie., 102: 18309-18314.

Neves, W.A.; Hubbe, M.; Okomura, M.M.M..; González-José, R.; Figuti, L.; Eggers, S. \& Blasi, P.A.D. 2005. A new early Holocene human skeleton from Brazil: implications for the settlement of the New World. J. Hum. Evol., 48: 403-414.

Neves, W.A.; Hubbe, M. \& Correal, G. 2007b. Human skeletal remains from Sabana de Bogotá, Colombia: a case of paleoamerican morphology late survival in South America?. Am J. Phys. Anthropol., 133: 1080-1098. 
Neves, W.A.; Meyer, D. \& Pucciarelli, H.M. 1996a. Early skeletal remains and the peopling of the Americas. Rev. Antropol., 39(2): 121-139.

Neves, W.A., Munford, D. \& Zanini, M.C. 1996b. Cranial morphological variation and the colonization of the New World: towards a four-migration model. Am. J. Phys. Anthropol., Sup 26: 169.

Neves, W.A.; Munford, D.; Zanini, M.C. \& Pucciarelli, H.M. 1999b. Cranial morphological variation in South America and the colonization of the New World: towards a four migration model?. Ciência e Cultura: J. Of the Brazilian Association for the Advanced of Science, 51(3/4): 151-165.

Neves, W.A.; Powell, J.P. \& Ozolins, E.G. 1999c. Extra-continental morphology affinities of Lapa Vermelha IV, Hominid I: a multivariate analysis with progressive numbers of variables. Homo, 50: 263-282.

Neves, W.A.; Powell, J.P. \& Ozolins, E.G. 1999d. Modern human origins as seen from the peripheries. J. Hum. Evol., 37: 129-133.

Neves, W.A., Powell, J.F. \& Ozolins, E.G. 1999e. Extra-continental morphological affinities of Palli Aike, Southern Chile. Interciência, 24(4): 258-263.

Neves, W.A. \& Pucciarelli, H.M. 1989. Extra-continental biological relationships of early South American human remains: a multivariate analysis. Ciência e Cultura, 41: 566-575.

Neves, W.A. \& Pucciarelli, H.M. 1990. The origin of the first Americans: an analysis based on the cranial morphology of early South American human remains. Am. J. Phys. Anthropol., 81: 274.

Neves, W.A. \& Pucciarelli, H.M. 1991. Morphological affinities of the first Americans: an exploratory analysis based on early South American human remains. J. Hum. Evol., 21: 261-273.

Neves, W.A. \& Pucciarelli, H.M. 1998. The Zhoukoudian Upper Cave skull 101 as seen from the Americas. J. Hum. Evol., 34: 219-222.

Neves, W.A.; Prous, A.; Gonzaléz-José, R.; Kipnis, R. \& Powell, J. 2003. Early Holocene human skeletal remains from Santana do Riacho, Brazil: implications for the settlement of the New World. J. Hum. Evol., 45: 19-42.

Neves, W.A.; Zanini, M.C.; Munford, D. \& Pucciarelli, H.M. 1999a. O povoamento da América à luz da morfologia craniana. Revista da USP, 34: 96-105.

Nichols, J. 1997. Modeling ancient populations structure and movement in linguistics. Annu. Rev. Anthropol, 26: 359-384.

Nogueira, A.R. 1973. A imigração japonesa para a lavoura cafeeira paulista (1908-1922). Inst. Est. Brasil., 28:247.

Olejniczak, A.J.; Gilbert, C.C.; Martin, L.B.; Smith, T.M.; Ulhaas, L. \& Grine, F.E. 2007. Morphology of the enamel-dentine junction in sections of anthropoid primate maxillary molars. J. Hum. Evol., 53(3): 292-301.

O'Rourke, D.H.; Hayes, M.G. \& Carlyle, S.W. 2000. Spatial and temporal stability of mtDNA haplogroup frequencies in native North America. Hum. Biol., 72(1): 15-34. 
Owsley, D.W. \& Jantz, R.L. 2005. Nearsightedness in Paleoamerican research: historical perspective and contemporary analysis. In.: R. Bonnichsen, B.T. Lepper, D. Stanford \& M.R. Waters (eds.) Paleoamerican origins: beyond Clovis. College Station: Texas A\&M University Press.

Pavlov, P., Svendsen, J.I. \& Indrelid, S. 2001. Human presence in the European arctic nearly 40,000 years ago. Nature, 413: 64-67.

Pena, S.D.J., Santos, F.R., Bianchi, N.O., Bravi, C.M., Carnese, F.R., Rothhammer, F., Gerelsaikhan, T., Munkhtuja, B. \& Oyunsurent, T. 1995. A major founder Y-chromosome haplotype in Amerindians. Nature Genet., 11: 15-16.

Penrose, L.S. 1954. Distance, size and shape. Ann. Eugen., 18: 337-343.

Perzigizn, A.J. 1976. The dentition of the Indian Knoll skeletal population: odontometrics and cusp number. Am. J. Phys. Anthropol., 44: 113-122.

Pietrusewsky, Michael, Li Yongyi, Shao Xiangqing, and Nguyen Quang Quyen. 1992. Modern and near modern populations of Asia and the Pacific: A multivariate craniometric in- terpretation. In.: T. Akazawa, K. Aoki \& T. Kimura (eds.). The evolution and dispersal of modern humans in Asia. Tokyo: Hokusen-sha. pp. 531-558.

Pilbrow, V. 2003. Dental variation in African apes with implications for understanding patterns of variation in species of fossil apes. PhD dissertation. New York: New York University.

Pilbrow, V. 2007. Patterns of molar variation in great apes and their implications for hominin taxonomy. In.: S.E. Bailey \& J.J. Hublin (eds.) Dental perspectives in dental evolution: state-of-theart research in dental paleoanthropolgy. Dordrecht, The Netherlands: Springer. pp. 9-32.

Pitulko, V.V., Nokolsky, P.A., Girya, E.Y., Basilyan, A.E. \& Tumskoy, V.E. 2004. The yana RHS site: humans in the arctic before the last glacial maximum. Science, 303: 52-56.

Powell, J.F. 1993. Dental evidence for the peopling of the New World: some methodological considerations. Hum. Biol., 65: 799-819.

Powell, J.F. 1995. Dental variation and biological affinity among middle Holocene humans populations in North America. [doutorado] Austin: University of Texas,

Powell, J.F. 1997. Variação dentária nas Américas: uma visão alternativa. Rev. USP, 34: 82-95.

Powell, J.F. \& Steele, D.G. 1992. A multivariate craniometric analysis of North American paleo-indian remains. Currt. Res. Pleist., 9: 59-62.

Powell, J.F. \& Neves, W.A. 1998. Dental diversity of early New World populations: taking a bit out of the tripartite model. Am. J. Phys. Anthropol. Supplem., 26: 178-180.

Powell, J.; Neves, W.A.; Ozolins, E. \& Pucciarelli, H.M. 1999. Afinidades biológicas extra-continentales de los dos esqueletos más antiguos de América: implicaciones para el poblamiento Del Nuevo Mundo. Antropol. Fis. Latinoam., 2: 7-22.

Powell, J. \& Neves, W.A. 1999. Cranialfacial morphology of the frist americans: pattern and process in the Peopling of the New World. Yearb. Phys. Anthropol, 42: 153-188. 
Powers, W.R. \& Hoffecker, J.F. 1989. Late Pleistocene settlement in the Nenana Valley, central Alaska. Am. Antiquity, 54(2): 263-287.

Prous, A. 1992. Arqueologia Brasileira. Brasília: Editora da Universidade de Brasília.

Prous, A. 1997. O povoamento da América visto do Brasil: uma perspectiva crítica. Rev. USP, 14: 821.

Prous, A. 2006. O Brasil antes dos brasileiros - a pré-história do nosso país. Rio de Janeiro: Jorge Zahar Editor.

Pucciarelli, H.M. Sardi, M.L.; López, J.C.J. \& Sanches, C.S. 2003. Early peopling and evolutionary diversification in América. Quater. Intern., 109-110: 123-132.

Pucciarelli, H. M., Neves, W. A., González-José, R., Sardi, M. L., Rozzi, F. R., Struck, A. \& Bonilla, M. Y. 2006. East-West cranial differentiation in pre-Columbian populations of south America. Hum. Biol., 57: 133-150.

Pucciarelli, H. M., González-José, R., Neves, W. A., Sardi, M. L. \& Rozzi, F. R. 2008. East-West cranial differentiation in pre-Columbian populations from Central and North America. J. Hum. Evol., 54: 296-308.

Reidla, M.; Kivisild, T.; Metspalu, E.; Kaldma, K.; Tambets, K.; Tolk, H.V.; Parik, J.; Loogväli, E.L.; Derenko, M.; Malyarchuk, B.; Bermisheva, M.; Zhadanov, S.; Pennarun, E.; Gubina, M.; Golubenko, M.; Damba, L.; Fedorova, S.; Gusar, V.; Grechanina, E.; Mikerezi, I.; Moisan, J.P.; Chaventré, A.; Khusnutdinova, E.; Osipova, L.; Stepanov, V.; Voevoda, M.; Achilli, A.; Rengo, C.; Rickards, O.; Stefano, G.F.; Papiha, S.; Beckman, L.; Janicijevic, B.; Rudan, P.; Anagnou, N.; Michalodimitrakis, E.; Koziel, S.; Usanga, E.; Geberhiwot, T.; Herrnstadt, C.; Howell, N.; Torroni, A. \& Villems, R. 2003. Origin and diffusion of mtDNA haplogroup X. Am. J. Hum. Genet., 73: 1178-1190.

Reis, E. 2001. Estatística Multivariada aplicada. Lisboa: Edições Sílabo

Reeves, B.O.K. 1973. The nature and age of the contact between the Laurentide and Cordilleran ice sheets in the western Interior of North America, Arct. Alpin. Res., 5: 1-16.

Richards, M.B.; Macaulay, V.A.; Bandelt, H.J.; Sykes, B.C. 1998. Phylogeography of mitochondrial DNA in western Europe. Ann. Hum. Genet., 62: 241-260.

Rivet, P. 1968. As origens do homem americano. São Paulo: Instituto Progresso Editorial.

Roosevelt, A.C., Douglas, J. \& Brown, L. 2002. The migrations and adaptations of the first Americans: Clovis and pre-Clovis viewed from South America. In: Jablonski, N. G. (editor). The first Americans. The Pleistocene colonization of the New World. San Francisco: California Academy of Science, pp. 159-223.

Saillard, J.; Forster, P.; Lynnerup, N.; Bandelt, H.J. \& Nørby, S. 2000. mtDNA Variation among Greenland Eskimos: The Edge of the Beringian Expansion. Am. J. Hum. Genet., 67(3): 18-726.

Salzano, F.M., Weimer, T.A., Franco, M.H.L.P., Hutz, M.H., Mestriner, M.A., Simões, A.L. \& Freitas, M.J.M. 1985. Demography and genetics of the Sateré-Mawé and their bearing on the differentiation 
of the Tupi tribes of the South América. J. Hum. Evol., 14: 647-655.

Salzano, F.M. \& Callegari-Jacques, S.M. 1988. A Amazônia como um microcosmo: populações indígenas. In: Neves, W. A. (org.) Biologia e Ecologia Humana na Amazônia: Avaliação e perspectivas. Belém: Museu Paraense Emíliom Goeldi.

Salzano, F.M. \& Callegari-Jacques, S.M. 1991. O índio da Amazônia: uma abordagem microevolucionária. In: Neves, W. A. (org.) Origens, adaptações e diversidade biológica do homem nativo da Amazônia. Belém: Museu Paraense Emíliom Goeldi.

Santos, F.R., Pandya, S., Tyler-Smith, C., Pena, S.D.J., Schanfield, M., Leonard, W.R., Osipova, L., Crawford, M.H. \& Mitchell, R.J. 1999. The central Siberian origin for native American Ychromossomes. Am. J. Hum. Genet., 64: 619-628.

Sardi, M.L., Rozzi, F.R., González-José, R. \& Pucciarelli, H.M. 2005. South Amerindian craniofacial morpholog: diversity and implications for amerindian evolution. Am. J. Phys. Anthropol., 1228: 747756.

Schurr, T.G., Ballinger, S.W., Gan, Y.Y. Hodge, J.A., Merrewether, D.A., Lawrence, D.N., Knowler, W.C., Weiss, K.M. \& Wallace, D.C. 1990. Amerindian mtDNA have rare Asian mutation at high frequencies, suggesting they derived from four primary maternal lineages. Am. J. Hum. Genet., 46: 613-623.

Schurr, T.G. \& Sherry, S.T. 2004. Mitochondrial DNA and Y-chromosome diversity and the peopling of the Americas. Am. J. Hum. Biol., 16(4): 420-39.

Schwartz, G.T. \& Dean, M.C. 2005. Sexual dimorphism in modern human permanent teeth. Am. J. Phys. Anthropol., 128: 312-317.

Scott, G.R. \& Turner II, C.G. 1997. The anthropology of modern human teeth: dental morphology and its variation in recent human populations. Cambridge: Cambridge University Press.

Scott, J.E. \& Lockwood, C.A. 2004. Patterns of tooth crow size and shape variation in great apes and humans and species recognition in the homind fossil record. Am. J. Phys. Anthropol., 125: 303-319.

Seielstad, M.; Yuldasheva, N.; Singh, N.; Underhill, P.; Oefner, P.; Shen, P. \& Wells, S. 2003. Letter to the Editor: A novel Y-chromossome variant puts an upper limit on the timing of frist entry into the Americas. Am J. Hum. Genet., 73: 700-705.

Sharma, J.C. 1983. Dental morphology and odontometry of the Tibetan immigrants. Am. J. Phys. Anthropol., 61: 495-505.

Silva Jr., W.A.; Bonatto, S.L.; Holanda, A.J.; Ribeiro-dos-Santos, A.K.; Paixão, B.M.; Goldman, G.H.; Abe-Sandes, K.; Rodriguez-Delfin, L.; Barbosa, M.; Paçó-Larson, M.L.; Petzl-Erler, M.L.; Valente, V.; Santos, S.E.B. \& Zago, M.A. 2002. Mitocondrial genome diversity of Native Americans supports a single early entry of founder populations into America. Am. J. Hum. Genet., 71: 187-192.

Smith, D.G.; Malhi, R.S.; Eshleman, J. \& Lorenz, J.G. 1999. Distribution of mtDNA haplogroup X among Native North Americans. Am. J. Phys. Anthropol., 110(3): 271-284. 
Sofaer, J.A.; Niswander, J.D.; MacLean, C.J. \& Workman, P.L. 1972. Population Studies on Southwestern Indian Tribes: V. tooth morphology as an indicator of biological distance. Am. J. Phys. Anthropol., 37: 357-366.

Stanford, D.; Bonnichsen, R.; Meggers, B. \& Steele, D.G. 2005. Paleoamerican origins: models, evidence and future directions. In.: R. Bonnichsen, B.T. Lepper, D. Stanford \& M.R. Waters (eds.) Paleoamerican origins: beyond Clovis. College Station: Texas A\&M University Press.

Starikovskaya, Y.B.; Sukernik, R.I.; Schurr, T.G.; Kogelnik, A.M. \& Wallace, D.C. 1998. mtDNA diversity in Chukchi and Siberian Eskimos: Implications for the genetic history of ancient Beringia and the peolpling of thr New World. Am. J. Hum. Genet., 63: 1473-1491.

Starikovskaya, E.B.; Sukernik, R.I.; Derbeneva, O.A.; Volodko, N.V.; Ruiz-Pesini, E.; Torroni, A.; Brown, M.D.; Lott, M.T.; Hosseini, S.H.; Huoponen, K. \& Wallace, D.C. 2005. Mitochondrial DNA Diversity in Indigenous Populations of the Southern Extent of Siberia, and the Origins of Native American Haplogroups. Ann. Hum. Genet., 69: 67-89.

Steele, D.G \& Powell, J.F. 1992. Peopling of the Americas: Paleobiological evidence. Hum. Biol., 64: 303-336.

Steele, D.G. \& Powell, J.F. 1993. Paleobiology of the first Americans. Evol. Anthropol., 2: 138-146.

Stojanowski, C.M., Larsen, C.S., Tung, T.A. \& McEwan, B.G. 2007. Biological structure and health implications from tooth size at Mission San Luis de Appalachee. Am. J. Phys. Anthropol., 132: 207222.

Stone, A.C. \& Stoneking, M. 1998. mtDNA Analysis of a Prehistoric Oneota Population: Implications for the Peopling of the New World. Am. J. Hum. Genet., 62: 1153-1170.

Sjøvold, T. 1973. The occurrence of minor non-metrical variants in the skeleton and their quantitative treatment for population comparisons. Homo, 24: 204-233.

Stringer, C.B., Humphrey, L.T. \& Compton, T. 1997. Cladistic analysis of dental traits in recent humans using a fossil outgroup. J. Hum. Evol., 32: 389-402.

Stringer, C.B. 1998. A metrical study of the WL-50 calvaria. J. Hum. Evol., 34: 327-332.

Surovell, T.A. 2003. Simulating coastal migration nin New World Colonization. Curr. Anthropol., 44(4): 580-591.

Sutter, R.C. 1997. Biological relations among prehistoric northern Chilean populations. A comparative study of dental morphology. Am. J. Phys. Anthropol., Supp. 24: 224.

Szathmary, E.J.E. 1986. Comments. Curr. Anthropol., 27: 490-491.

Szathmary, E.S.E. 1993. mtDNA and the peopling of the Americas. Am. J. Hum. Genet., 53: 793-799.

Tamm, E., Kivisild, T., Reidla, M., Metspalu, M., Smith, D.G., Mulligan, C.J., Bravi, C.M., Rickards, O., Martinez-Labarga, C., Khusnutdinova, E.K., Fedorova, S.A., Golubenko, M.V., Stepanov, V.A., Gubina, M.A., Zhadanov, S.I., Ossipova, L., Damba, L., Voevoda, M.I., Dipierri, J.E., Vilems, R. \& Malhi, R. 2007. Beringian standstill and spread of native american founders. PloS ONE, 9: 1-6, 
e829.

Tarazona-Santos, E. \& Santos, F. 2002. The Peopling of the Americas: A Second Major Migration? Am. J. Hum. Genet., 70: 1377-1380.

Torroni, A., Schurr, T.G., Yang, C.C., Szathmary, E.J.E., Willians, R.C., Schanfield, M.S., Troup, G.A., Knowler, W.C., Lawrence, D.N., Weiss, K.M. \& Wallace, D.C. 1992. Native american mitochondrial DNA analysis indicates that the amerind and the Nadene populations were founded by two independent migrations. Gentics, 130: 153-162.

Townsend, G.C. 1985. Intercuspal distances of maxillary pré-molar teeth in Australian Aboriginals. J. Dent. Res., 64: 443-446.

Townsend, G.C., Richards, L. \& Hughes, T. 2003. Molar intercuspal dimensions: genetic input to phenotypic variation. J. Dent. Res., 82(5): 350-355.

Turner II, C.G. 1981. Dentition of Chilean paleo-indians and peopling of the americas. Science, 212: 1053-1055.

Turner II, C.G. 1983. Dental evidence for the peopling of the Americas. In: Shutler Jr., R. (ed.). Early Man in the New World. Beverly Hills: Sage Publications.

Turner II, C.G. 1985. The dental search for native American origins. In (R. Kirk \& E. Szathmary, Eds) Out of Asia: Peopling the Americas and the Pacific, pp. 31-78. Canberra: The Journal of Pacific History.

Turner II, C.G. 1987. Late Pleistocene and Holocene population history of East Asia based on dental variation. Am. J. Phys. Anthropol., 73: 305-322.

Turner II, C.G. 1990. Major features of sundadonty and sinodonty, including suggestions about East Asian microevolution, population history, and late Pleitocene relationships with Australian Aboriginals. Am. J. Phys. Anthropol., 82: 295-317.

Turner II, C.G. 1992. The dental bridge between Australian and Asia: following Macintosh into the East Asian hearth of humannity. Persp. Hum Biol. 2 / Archaeol. Oceania, 27: 120-127.

Turner II, C.G. 2002. Teeth, needles, dogs, and Siberia: bioarchaeological evidence for the colonization of the New World. In: Jablonski, N. G. (editor). The first Americans. The Pleistocene colonization of the New World. San Francisco: California Academy of Science, 123-158.

Turner II, C.G. 2005. A Synoptic history os Physical Anthropology studies on the peopling of Alaska and the Americas. Alaska J. Anthropol., 3(1): 157-178.

Turner II, C.G. \& Bird, J. 1981. Dentition of Chilean Paleo-Indians and peopling of the Americas. Science, 212: 1053-1055.

Turner II, C.G. \& Hawkey D.E. 1998. Whose teeth are these? Carabelli's trait. In: Lukacs JR, editor. Human dental development, morphology, and pathology: a tribute to Albert A. Dahlberg. Eugene: Univ. Oregon Anthropol. Pape., 54: 41-50.

Turner II, C.G.; Nichol, C.R. \& Scott, G.R. 1991. Scoring procedures for key morphological traits of 
the Permanent dentition: the Arizona State University Dental Anthropology System. In: Kelly, M.; Larsen, C. (eds.), Advances in Dental Anthropology. Wiley: NewYork, pp. 13-31.

Turner II, C.G. \& Scott, G.R. 1977. DentitionofEasterIsland. In: Graber, T.M. (ed.) Orofacial growth and development. Chicago: Mouton Publishers . pp. 229-250.

Underhill, P.A.; Jin, I.; Zemans, R.; Oefner, P.J. \& Cavalli-Sforza, L.L. 1996. A pré-Columbian Ychromossome-specific transition and its implications for human evolutionary history. Proc. Natl. Acad. Sci., 93: 196-200.

Vodanović, M.; Demo, Z.; Njemirovskij, V.; Keros, J. \& Brkić, H. 2007. Odontometrics: a useful method for sex determination in na archaeological skeletal population?. J. Archaeol. Scie., 34: 905913.

Volodko, N.V., Starikovskaya, E.B., Mazunin, I.O., Eltsov, N.P., Naidenko, P.V., Wallace, D.C. \& Sukernik, R. 2008. Mitochondrial genome diversity in arctic siberians with particular reference to the evolutionary history of Beringia and Pleistocene peopling of the americas. Am. J. Hum. Genet., 82: 1084-1100.

Von Koenigswald, G.C. 1952. Gigantopithecus blacki, a giant fossil hominoid from the Pleistocene of southern China. Anthropol. Pap. Am. Mus. Nat. Hist., 43: 295-325.

Walters, M.R. \& Stafford Jr, T.W. 2007. Redefining the Age of Clovis: Implications for the Peopling of the Americas. Science, 315: 1122-1126.

Wang, S., Lewis Jr, C.M., Jakobson, M., Ramachandran, S., Ray, N. Bedoya, G., Rojas, W., Parra, M.V., Molina, J.A., Gallo, C., Mazzotti, G., Poletti, G., Hill, K., Hurtado, A.M., Labuda, D., Klitz, W., Barrantes, R., Bortoloni, M.C., Salzano, F.M., Petzl-Erler, M.L., Tsuneto, L.T., Llop, E. Rothhammer, F., Excoffier, L., Feldman, M.W., Rosenberg, N.A. \& Ruiz-Linares, A. 2008. Genetic variantion and population structure in native americans. PloS Genetics, 3(11): 2049-2067.

Williams, R.C., Steinberg, A.G., Gershowitz, H., Bennett, P.H., Knowler, W.C., Pettitt, D.J., Butler, W., Baiard, R., Dowda-Rea, L., Burch, T. A., Morse, H.G. \& Smith, A.G. 1985. GM allotypes in Native Americans: evidence for three distant migrations across the Bearing land bridge. Am. J. Phys. Anthropol., 66: 1-20.

Wolpof, M.H. 1971. Metric trends in hominid dental evolution. Cleveland: Case Reserve Univ. Press. Wood, B.A.; Abbott, S.A. \& Graham, S.H. 1983. Analysis of the dental morphology of Plio-Pleistocene hominids. II. Mandibular molars--study of cusp areas, fissure pattern and cross sectional shape of the crown. J. Anat., 137(2): 287-314.

Wood, B.A. \& Uytterschaut, H. 1987. Analysis of the dental morphology of Plio-Pleistocene hominids. III. Mandibular premolar crowns. J. Anat., 154: 121-156.

Wood, B.A. \& Engleman, C.A. 1988. Analysis of the dental morphology of Plio-Pleistocene hominids. V. Maxillary postcanine tooth morphology. J. Anat., 161: 1-35.

Wood, B.A. 2007. Introduction In.: S.E. Bailey \& J.J. Hublin (eds.) Dental perspectives in dental 
evolution: state-of-the-art research in dental paleoanthropolgy. Dordrecht, The Netherlands: Springer. pp. 231-236.

Yamada, H. \& Brown, T. 1990. Shape components of the maxillary molars. Am. J. Phys. Anthropol., 82: $275-282$.

Yesner, D.R. 2001. Human dispersal into interior Alaska: antecedent conditions, mode of colonization, and adaptations. Quater. Scie. Rev., 20: 315-327.

Yokoyama, Y.; Lambeck, K.; Deckker, P.D.; Johnston, P. \& Fifield, L.K. 2000. Timing of the Last Glacial Maximum form observed sea-level minima. Nature, 406: 713-716.

Zegura, S.L., Karafet, T.M., Zhivotovsky, L.A. \& Hammer, M.F. 2004. High-resolutions SNPs and microsatellite haplotypes point to a single, recent entry of Native American $Y$ chromosomes into the Americas. Mol. Biol. Evol., 21: 164-175. 